\title{
City of San Luis Obispo Community and Municipal Operations 2005 Baseline Greenhouse Gas Emissions Inventory
}

(A Report for the Community Development Department of the City of San Luis Obispo)

\author{
A Professional Project \\ Presented to \\ The Faculty of California Polytechnic State University \\ San Luis Obispo
}

In Partial Fulfillment of the Requirements for the Joint Transportation Planning Degree

Master of City and Regional Planning/Master of Science in Engineering

(Transportation Planning Specialization)

By Geoffrey M. Chiapella

March 2010 
(C) 2010

Geoffrey M. Chiapella

ALL RIGHTS RESERVED 


\section{COMMITTEE MEMBERSHIP}

TITLE:

AUTHOR:

DATE SUBMITTED:

COMMITTEE CHAIR:

COMMITTEE MEMBER:
City of San Luis Obispo: Community and Municipal Operations 2005 Baseline Greenhouse Gas Emissions Inventory

Geoffrey M. Chiapella

March 2010
Cornelius Nuworsoo, Ph.D., AICP

Assistant Professor

City and Regional Planning Department

California Polytechnic State University, San Luis Obispo

Ken Topping, FAICP

Lecturer

City and Regional Planning Department

California Polytechnic State University, San Luis Obispo

Kim Murry

Deputy Director, Long Range Planning

Community Development Department

City of San Luis Obispo 


\section{ABSTRACT \\ City of San Luis Obispo: Community and Municipal Operations \\ 2005 Baseline Greenhouse Gas Emissions Inventory \\ Geoffrey M. Chiapella}

The passage of $\mathrm{AB} 32$ in 2006 initiated the need for city planners in California to consider the quantification of greenhouse gas emissions at the community level in order to develop policies and programs to reduce emissions in the future. Although local jurisdictions are not required to quantify and report emissions at this time, the AB 32 Climate Change Scoping Plan recommended a reduction goal for local governments of 15 percent below today's levels by 2020 to ensure consistent reduction goals at the state and local levels.

ICLEI-Local Governments for Sustainability initiated the Cities for Climate Protection (CCP) campaign in 1993, which provides a framework for local governments to develop a baseline emissions inventory and identify reduction measures as part of a climate action plan. This inventory is developed under the framework of the CCP campaign.

A review of the current practice of local greenhouse gas emissions inventories in California identified significant consistencies across jurisdictions in the overall framework of community and municipal emissions inventories- due largely to the framework provided by the CCP campaign. However, data sources used and methods of measurement vary greatly among local inventories, which limit the ability to compare results. This highlights the need for a standard reporting protocol for community inventories.

This baseline emissions inventory document provides the technical information necessary for the city to set reduction goals and facilitates the development of the climate action plan outlining policies and programs that when implemented would reach those goals.

Keywords: greenhouse gas emissions inventory, climate change, AB 32, ICLEI, CCP campaign 


\title{
ACKNOWLEDGMENTS
}

The author would like to thank the following people for contributing data, technical expertise, and overall guidance to support the development of this emissions inventory:

\section{City of San Luis Obispo}

Kim Murry (Project Manager), Deputy Director, Community Development Department

Christine Mulholland, former Council Member

Tim Bochum, Deputy Director, Public Works Department

Dave Smith, Administrative Director, Public Works Department

Ron Holstine, Fleet Supervisor, Public Works Department

John Webster, Transit Manager, Public Works Department

Doug Dowden, Storm Water Code Enforcement, Public Works Department

Jake Hudson, Senior Traffic Engineer, Public Works Department

Dee Lawson, Transit Assistant, Public Works Department

Ron Munds, Utilities Conservation Coordinator, Utilities Department

Gary Henderson, Water Division Manager, Utilities Department

Alice Carter, Conservation Division, Utilities Department

The following departments for providing employee business travel data:

Community Development, Fire, Finance, Police, and Utilities

\section{San Luis Obispo County Air Pollution Control District}

Aeron Arlin-Genet, Supervising Air Quality Specialist, Planning and Outreach Division

Melissa Guise, Air Quality Specialist, Planning and Outreach Division

\section{Pacific Gas and Electric}

Jeremy Howard and Corie Cheeseman

\section{Southern California Gas Company/Sempra Utilities}

Frank Mateo

Waste Connections, Inc.

Tom Martin

\section{San Luis Obispo County Integrated Waste Management Authority \\ Peter Cron}

\author{
Pacific Municipal Consultants \\ Tammy Seale, Project Manager \\ Jaime Hill, Associate Planner \\ Jillian Rich, Associate Planner
}

\section{ICLEI - Local Governments for Sustainability}

Alison Culpen, Program Associate

Micah Lang, Program Associate 
I would like to extend my sincere thanks to the members of my project defense committee for taking the time to participate in the review and defense of this professional project: Cornelius Nuworsoo, Kim Murry, and Ken Topping.

I would especially like to thank Cornelius, project advisor and committee chair, for offering continued support and advice on this project over the last two years and continuing to push me to succeed.

I would also especially like to thank Kim, project manager and committee member, for her continued patience throughout the course of this project and her willingness to take a chance with having me take on this project.

I would also like to thank Ken for agreeing to be on my committee and reviewing this project document. I would also like to thank Becky Powell for providing final edits on this project document. 


\section{Table of Contents}

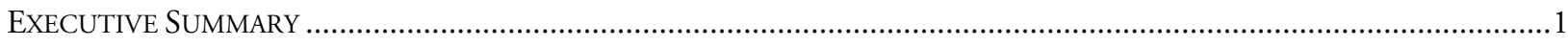

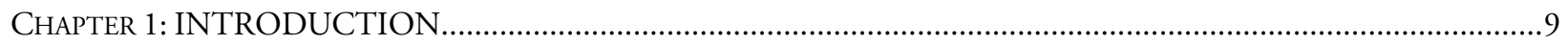

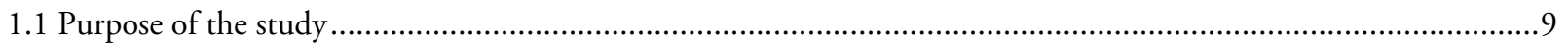

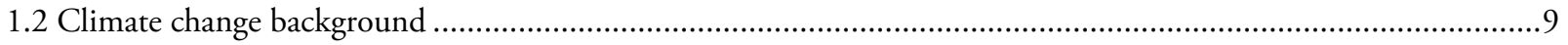

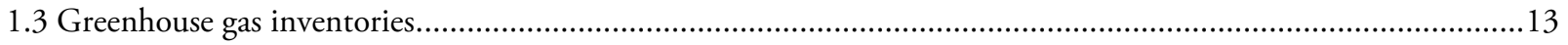

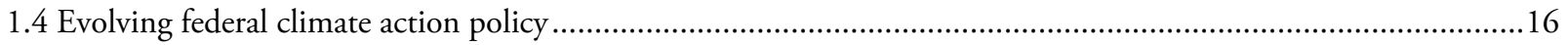

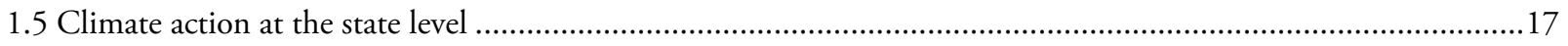

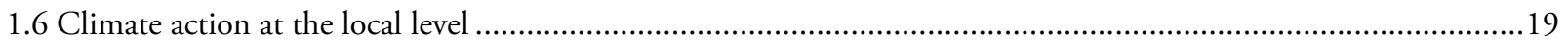

CHAPTER 2: REVIEW OF CURRENT PRACTICE

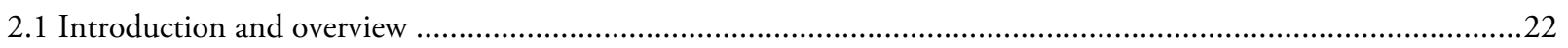

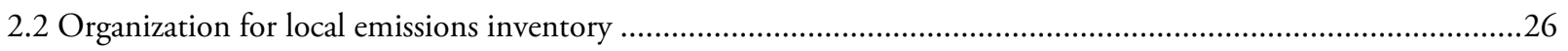

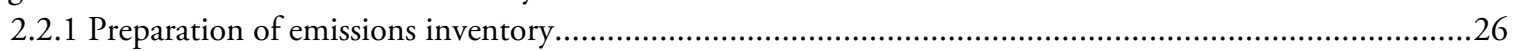

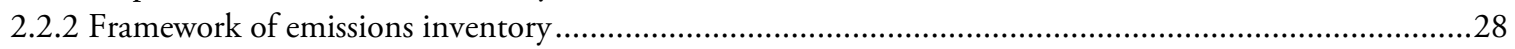

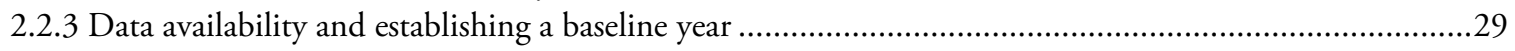

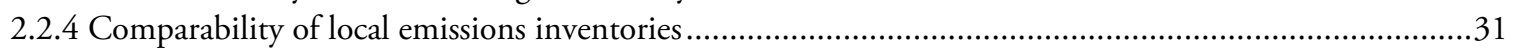

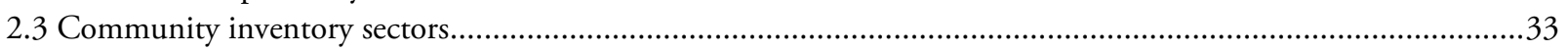

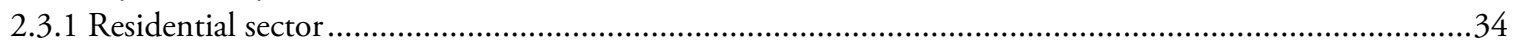

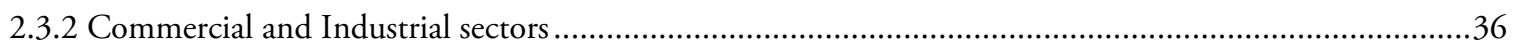

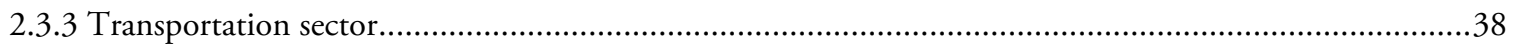

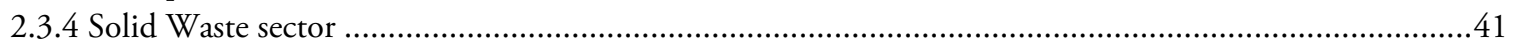

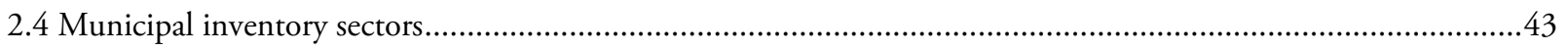

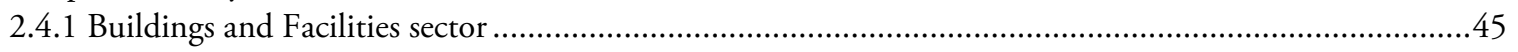

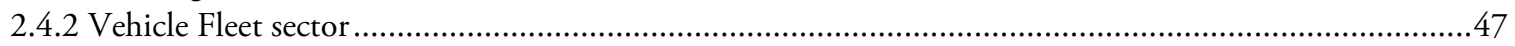

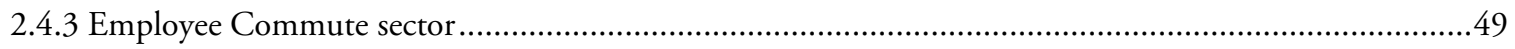

2.4.4 Streetlight and Traffic Signal sector ……................................................................................

2.4.5 Water and Sewer sector...........................................................................................................

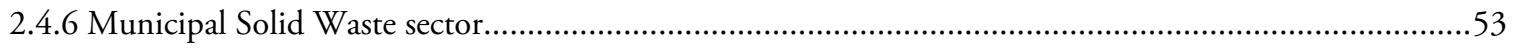

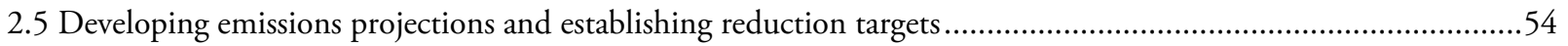

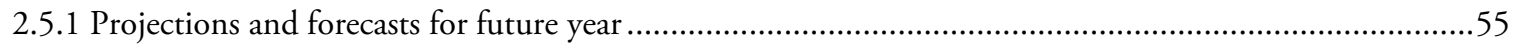

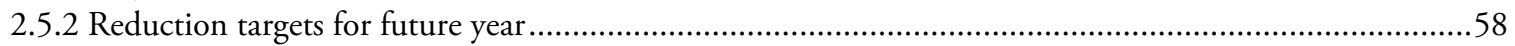

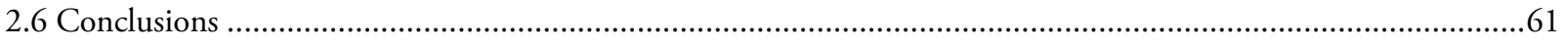

CHAPTER 3: COMMUNITY AND MUNICIPAL OPERATIONS INVENTORY METHODOLOGY ......................65

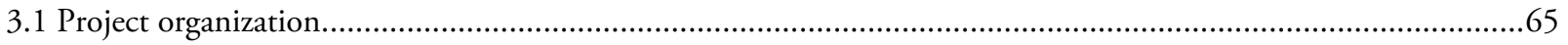

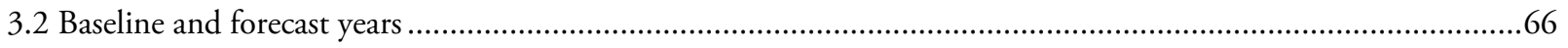

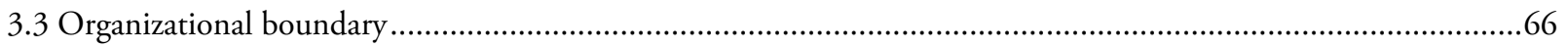

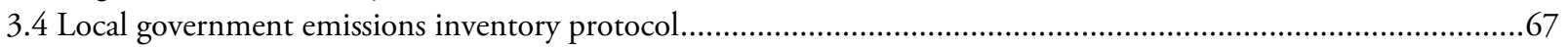

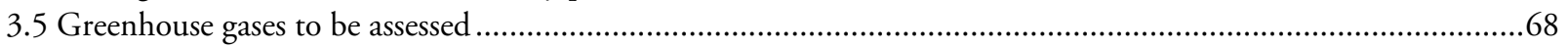

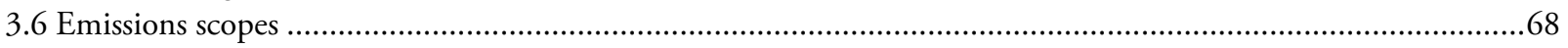

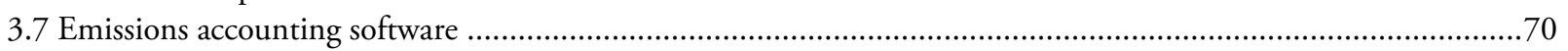

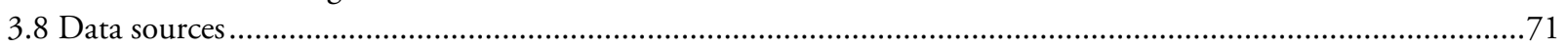

3.9 Community inventory data collection methodology …............................................................................73

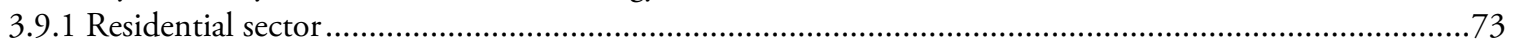

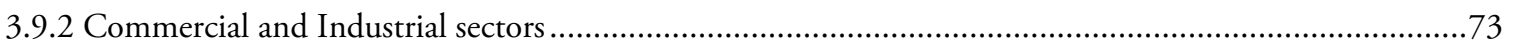

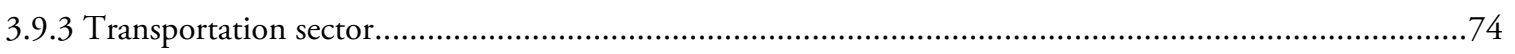

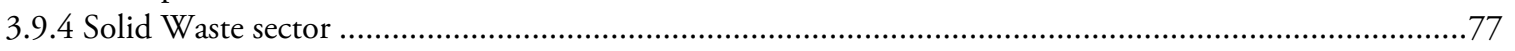

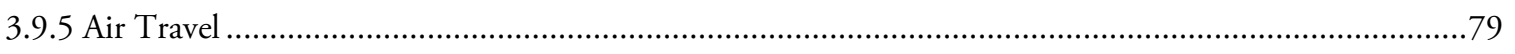

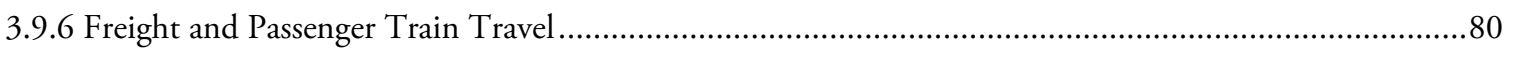

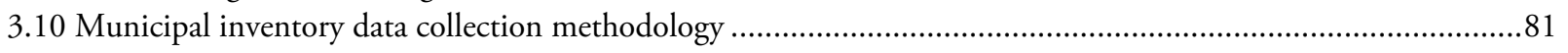




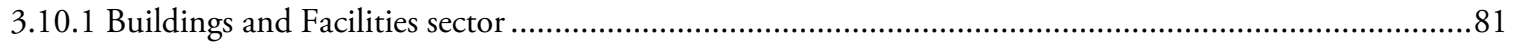

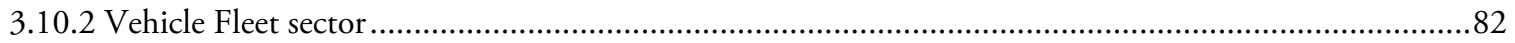

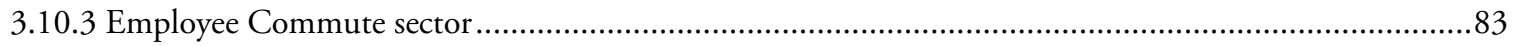

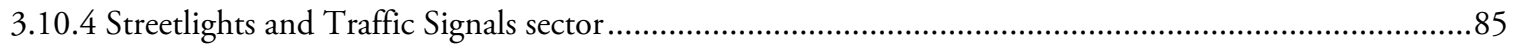

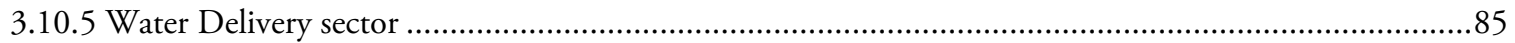

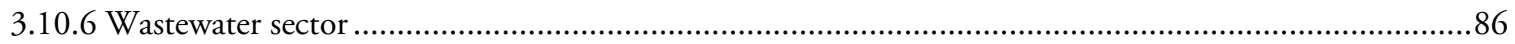

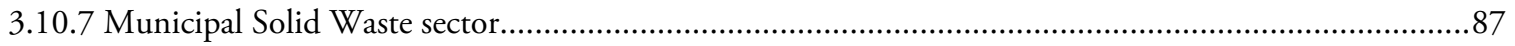

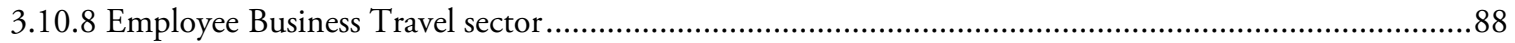

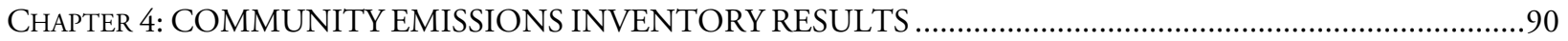

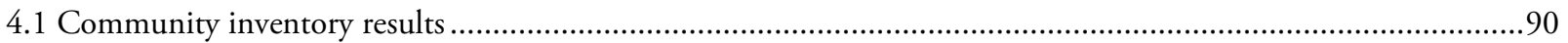

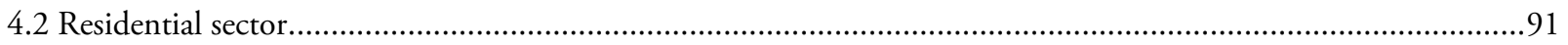

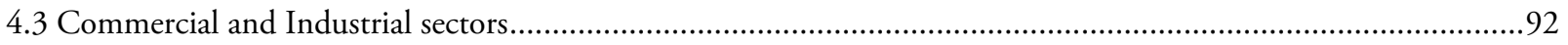

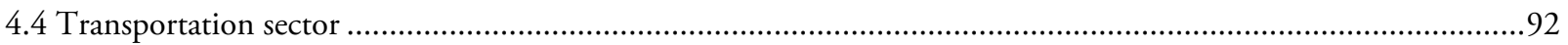

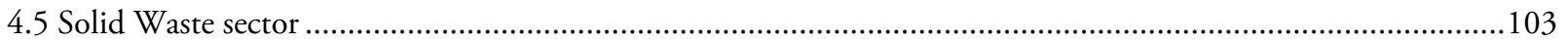

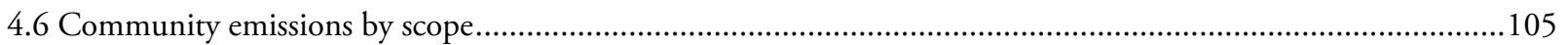

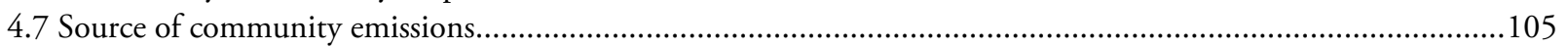

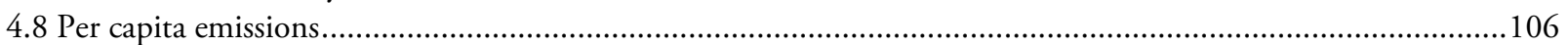

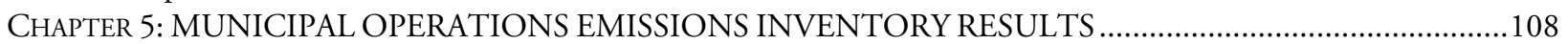

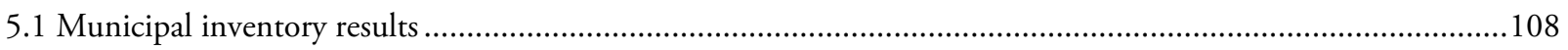

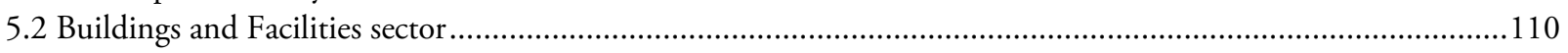

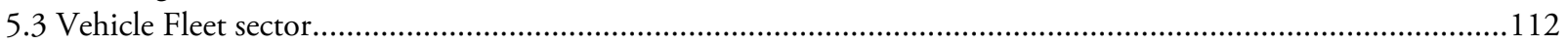

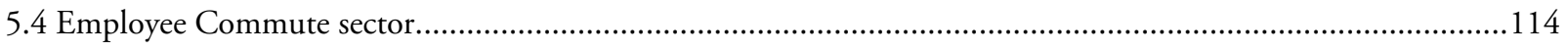

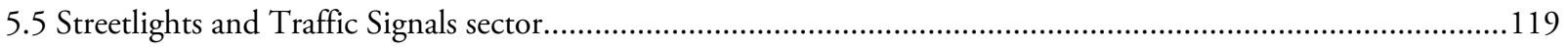

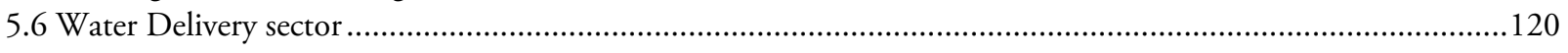

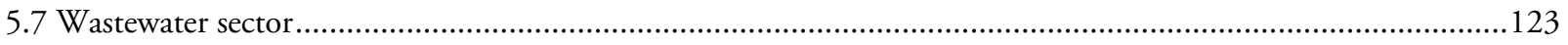

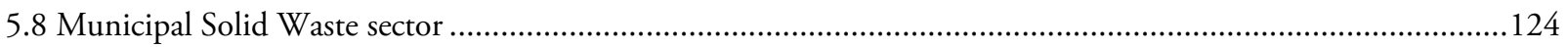

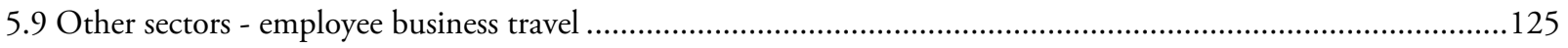

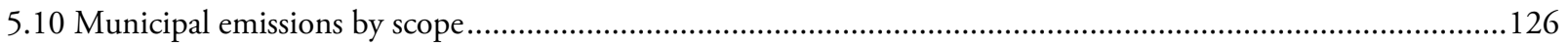

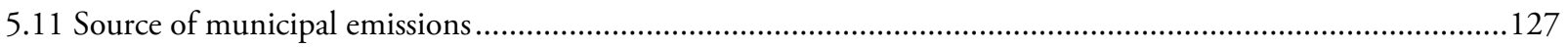

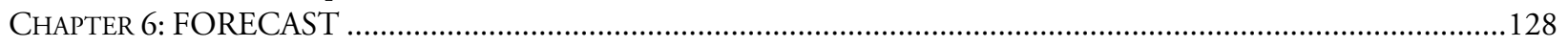

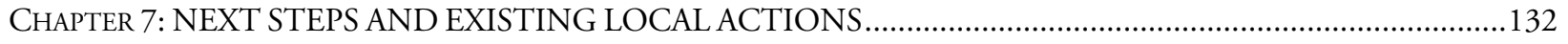

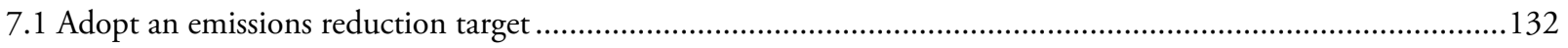

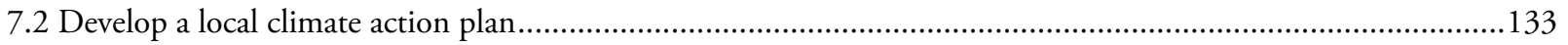

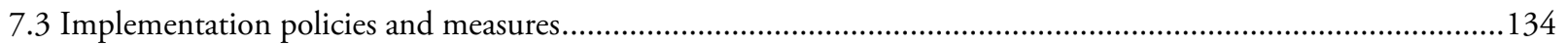

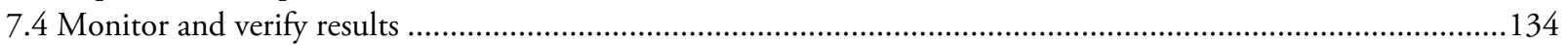

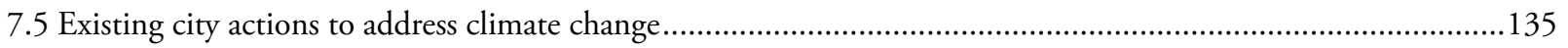

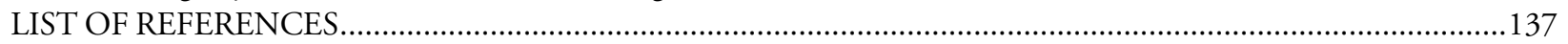

APPENDIX A - DETAILED COMMUNITY EMISSION INVENTORY FIGURES AND NOTES ……..........................................139

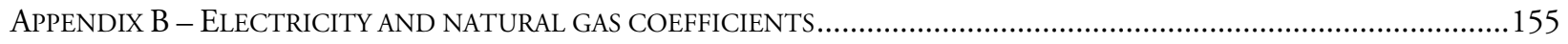

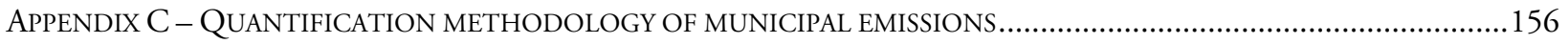

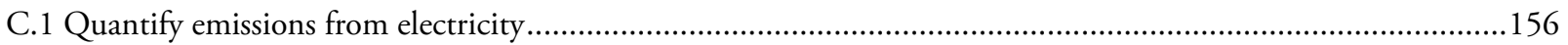

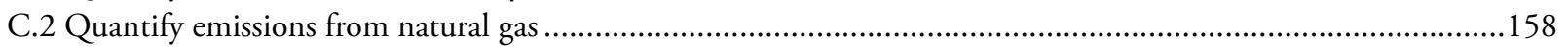

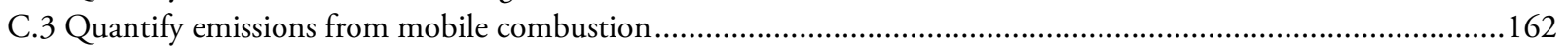

APPENDIX D - U.S. MAYORS Climate Protection AGREEMENT.............................................................................167 


\section{List of Tables}

TABLE 1.1: Global warming potentials for greenhouse gases ...............................................................................13

TABLE 2.1: Summary results of greenhouse gas inventories of selected California cities...............................................23

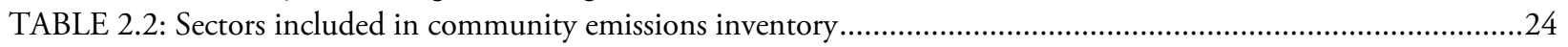

TABLE 2.3: Comparison of per capita emissions by sector for selected inventories......................................................25

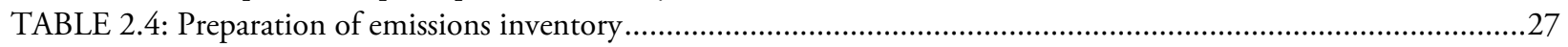

TABLE 2.5: Framework for emissions inventory and emissions software used .........................................................29

TABLE 2.6: Baseline year of inventory and data collected for multiple years ..............................................................30

TABLE 2.7: Presence of unique or major facilities in or adjacent to jurisdiction............................................................ 31

TABLE 2.8: Residential sector - data source and emissions calculation methodology ...................................................35

TABLE 2.9: Commercial and Industrial sectors - data source and emissions calculation methodology ............................37

TABLE 2.10: Transportation sector - data source and emissions calculation methodology ...........................................39

TABLE 2.11: Solid waste sector - data source and emissions calculation methodology ................................................42

TABLE 2.12: Municipal emissions as a percentage of community emissions ...........................................................44

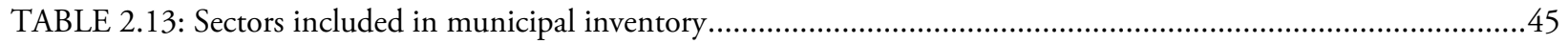

TABLE 2.14: Buildings and facilities sector - emissions calculation methodology and data presentation........................46

TABLE 2.15: Vehicle fleet sector - emissions calculation methodology and data presentation ......................................4 48

TABLE 2.16: Employee commute sector - emissions calculation methodology and data presentation.............................49

TABLE 2.17: Streetlights and traffic signals sector - emissions calculation methodology and data presentation ..............51

TABLE 2.18: Water and sewer sector - emissions calculation methodology and data presentation ................................52

TABLE 2.19: Solid Waste sector - emissions calculation methodology and data presentation ........................................54

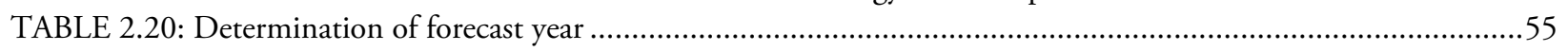

TABLE 2.21: Methodology for developing greenhouse gas emissions projections ........................................................57

TABLE 2.22: Establishment of greenhouse gas emission reduction target.....................................................................59

TABLE 3.1: Data sources for community emissions inventory ............................................................................71

TABLE 3.2: Data sources for municipal emissions inventory ………........................................................................

TABLE 4.1: Energy consumption and greenhouse gas emissions ............................................................................91

TABLE 4.2: Residential sector - emissions by fuel type (2005) ……....................................................................

TABLE 4.3: Commercial and industrial sectors - emissions by fuel type (2005)........................................................92

TABLE 4.4: Summary of city-wide traffic counts program (2005-2006) .................................................................93

TABLE 4.5: Comparison of two sources of historic trends in DVMT in San Luis Obispo (1996-2007) .......................98

TABLE 4.6: Comparison of three calculations of DVMT on San Luis Obispo roads (2005) ......................................100

TABLE 4.7: Solid waste tonnage in San Luis Obispo (2005-2007) ......................................................................104

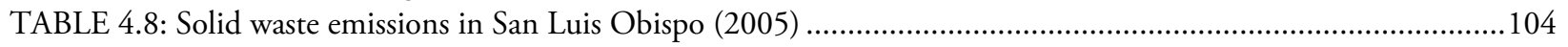

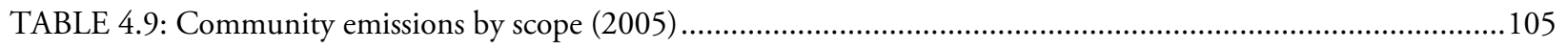

TABLE 4.10: Per capita emissions of selected California jurisdictions ........................................................................107

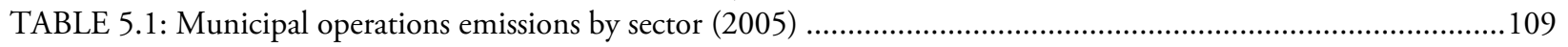

TABLE 5.2: Electricity usage of buildings and facilities and emissions (2005) .........................................................111

TABLE 5.3: Natural gas usage of buildings and facilities and emissions (2005) ....................................................111

TABLE 5.4: Propane usage of buildings and facilities and emissions (2007 \& 2008) ................................................112

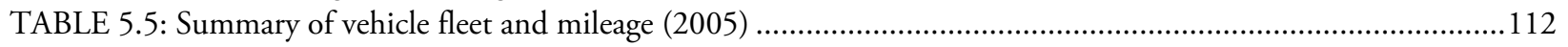

TABLE 5.6: Vehicle fleet fuel usage (2007 and 2008) .....................................................................................113

TABLE 5.7: Transit vehicle fleet mileage and emissions (2005) ...........................................................................114

TABLE 5.8: Summary of employee commute mileage by mode and emissions.........................................................118

TABLE 5.9: Employee commute mileage and emissions averted (2007) .................................................................119

TABLE 5.10: Streetlights and traffic signals electricity usage and emissions (2005) ..................................................120

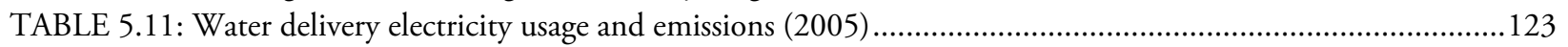

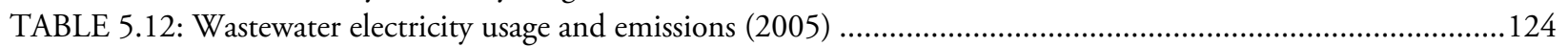

TABLE 5.13: Wastewater natural gas usage and emissions (2005) ...........................................................................124 


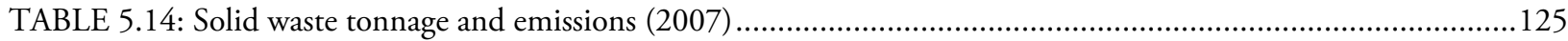

TABLE 5.15: Employee business travel mileage and emissions (2005) .................................................................126

TABLE 5.16: Total municipal operations emissions by scope (2005) ......................................................................126

\section{$\underline{\text { List of Figures }}$}

FIGURE 1.1: Illustration of greenhouse effect

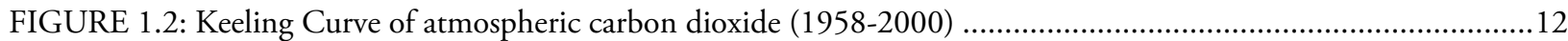

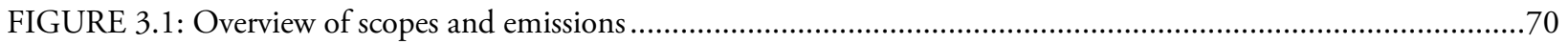

FIGURE 4.1: City of San Luis Obispo greenhouse gas emissions by sector (2005) ...................................................90

FIGURE 4.2: Vehicle-miles of travel sub-areas in San Luis Obispo (2005-2006) ......................................................95

FIGURE 4.3: Comparison of two sources of historic trends in DVMT in San Luis Obispo (1996-2007).....................99

FIGURE 4.4: Comparison of road-miles included in three calculations of DVMT in San Luis Obispo (2005) ...........101

FIGURE 4.5: Comparison of three calculations of DVMT in San Luis Obispo (2005) ..............................................102

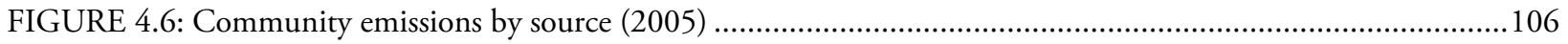

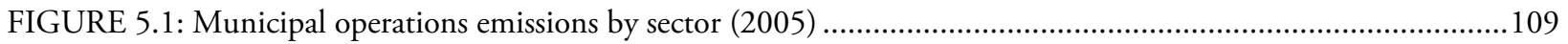

FIGURE 5.2: Municipal operations contribution to community emissions (2005) ……..........................................110

FIGURE 5.3: Employee commute mode by primary and secondary mode (2007) ...................................................116

FIGURE 5.4: Distribution of city employees' distance to work (2007) ..................................................................117

FIGURE 5.5: Municipal operations greenhouse gas emissions by source (2005) ......................................................127

FIGURE 6.1: "Business-as-usual” projection of emissions in San Luis Obispo (2005-2020).....................................128

FIGURE 7.1: Emissions forecast in relation to 15 percent reduction target $(2005-2020)$.........................................133

\section{Appendix Tables and Equations}

Table A.1: Buildings and facilities electricity usage and emissions (2005)

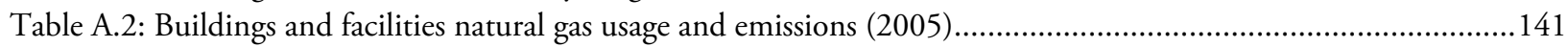

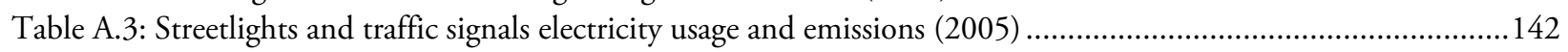

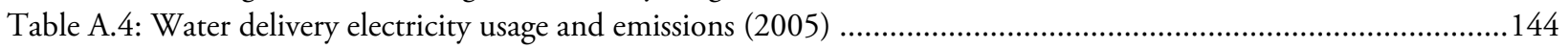

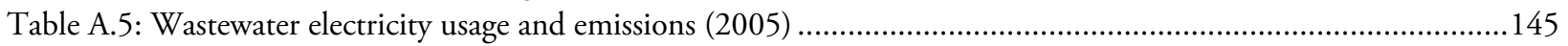

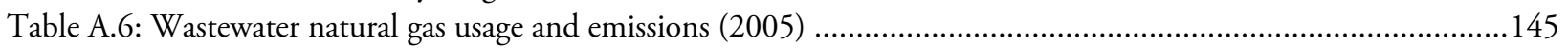

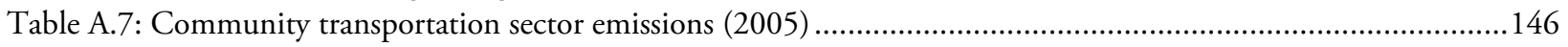

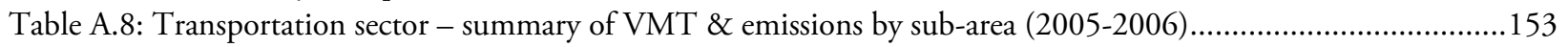

Table A.9: Transportation sector - emissions per lane-mile by sub-area (2005-2006) .................................................154

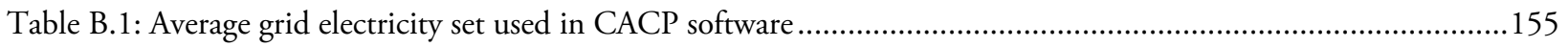

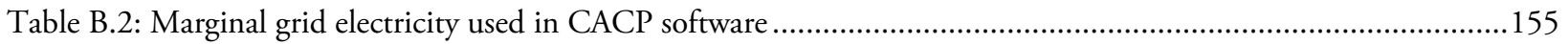

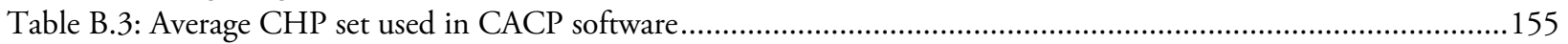

Table B.4: California coefficients for natural gas used in CACP software .................................................................155

Equation C.1: Calculate indirect emissions from electricity use ……...................................................................158

Equation C.2: Convert to $\mathrm{CO}_{2}$-equivalent emissions and determine total emissions ...............................................158

Equation C.3: Calculate $\mathrm{CO}_{2}$ emissions from stationary combustion (fuel use in $\mathrm{MMBtu}$ ) ......................................160

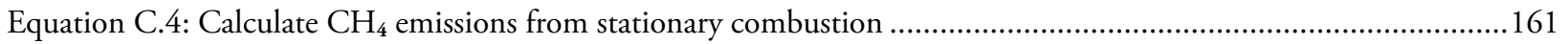

Equation C.5: Calculate $\mathrm{N}_{2} \mathrm{O}$ emissions from stationary combustion ..................................................................161

Equation C.6: Convert to $\mathrm{CO}_{2}$-equivalent emissions and determine total emissions ...................................................161

Equation C.7: Account for changes in fuel stocks from bulk purchases.....................................................................163

Equation C.8: Calculate $\mathrm{CO}_{2}$ emissions from mobile combustion.......................................................................164

Equation C.9: Calculate $\mathrm{CH}_{4}$ emissions from mobile combustion.......................................................................166

Equation C.10: Calculate $\mathrm{N}_{2} \mathrm{O}$ emissions from mobile combustion ……..........................................................166 


\section{Executive Summary}

There is increasing scientific evidence that increasing levels of carbon dioxide $\left(\mathrm{CO}_{2}\right)$ and other greenhouse gases released into the atmosphere will have a profound effect on the Earth's climate, increasing the risk of extreme weather events, changing rainfall and crop productivity patterns, and the migration of infectious diseases. It is a well-researched fact that the combustion of fossil fuels releases greenhouse gases into the atmosphere, causing average global surface temperatures to increase.

Climate change is quickly becoming a priority among policy makers and citizens alike. In January 2008, the San Luis Obispo City Council made a commitment to quantify the community's generation of greenhouse gas emissions through the development of a Community and Municipal Operations Baseline Greenhouse Gas Emissions Inventory. This inventory identifies the major sources of greenhouse gas emissions within the city and provides a baseline against which future progress can be measured. This inventory includes two components: a community emissions inventory and a municipal emissions inventory. It is important to note that the municipal inventory should not be added to the community inventory; but rather the community inventory should be considered to be inclusive of the municipal operations inventory. Specifically, this inventory does the following:

- Calculates emissions from community activities, including those generated by municipal operations, within the City's jurisdictional boundary in 2005;

- Identifies the major sources of emissions from community sources and municipal operations;

- Provides decision-makers and the community with baseline information to help set the framework for the climate action planning process; and 
- Forecasts how emissions could increase in the community in a "business-as-usual" scenario.

This local emissions inventory represents the completion of the first step in San Luis Obispo's climate protection process. As advised by ICLEI-Local Governments for Sustainability, it is essential to first quantify recent-year emissions to establish: (1) a baseline, against which to measure future progress, and (2) an understanding of where the highest percentages of emissions are coming from, and, therefore, where the greatest opportunities for emissions reductions exist.

Through energy efficiency in its facilities and vehicle fleet, clean alternative energy sources, sustainable purchasing and waste reduction efforts, smart land use and transportation planning, San Luis Obispo can achieve multiple benefits, including lower energy bills, improved air quality, economic development, reduced emissions, and a better quality of life throughout the community. Reporting the community's emissions will aid policy-makers in forecasting emission trends, identifying the point and mobile sources of emissions generated, and setting future reduction targets and mitigation measures.

\section{Community greenhouse gas inventory results}

This greenhouse gas inventory report identifies that the community of San Luis Obispo emitted approximately 264,237 metric tons of carbon dioxide equivalent $\left(\mathrm{MTCO}_{2} \mathrm{e}\right)$ emissions in the baseline year of 2005. As shown in Figure 1, the transportation sector was the largest contributor of emissions (50.0 percent), producing approximately 132,137 $\mathrm{MTCO}_{2} \mathrm{e}$ emissions in 2005. Emissions from the residential sector accounted for 21.0 percent of the total emissions, while emissions from 
the commercial and industrial sector accounted for 21.9 percent of the total emissions. The solid waste sector generated the remaining 7.1 percent of community emissions.

Figure 1:

Community Greenhouse Gas Emissions by Sector

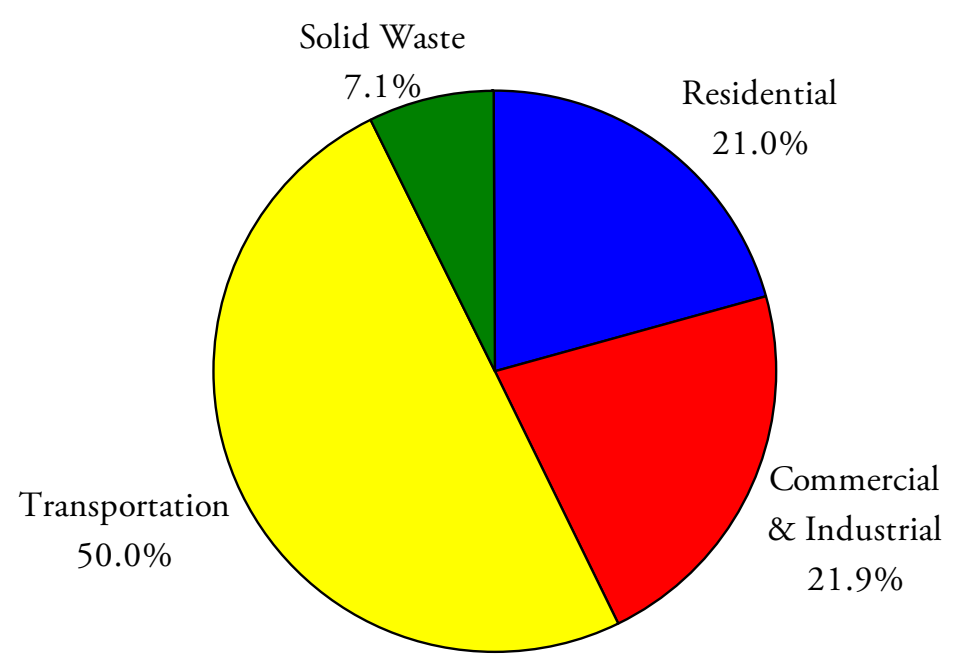

The majority of emissions from the transportation sector were the result of gasoline consumption in private vehicles traveling on city roadways and on U.S. 101 through the community. Vehicle-miles of travel on U.S. 101 accounted for 30.7 percent of all transportation sector emissions and 15.3 percent of community-wide emissions. Greenhouse gas figures from the solid waste sector are the estimated future emissions that will result from the decomposition of waste generated by county residents and businesses in the base year 2005, with a methane recovery factor of 60 percent.

\section{Municipal operations inventory results}

In 2005, the municipal operations of the City of San Luis Obispo generated 6,580 $\mathrm{MTCO}_{2} \mathrm{e}$ emissions, and consumed approximately 94,483 MMBtu of energy. The total cost associated with 
annual energy and fuel usage in 2005 was $\$ 1.871$ million. The city's operations generate about 2.5

percent of all community emissions.

Figure 2:

Municipal Operations GHG Emissions by Sector

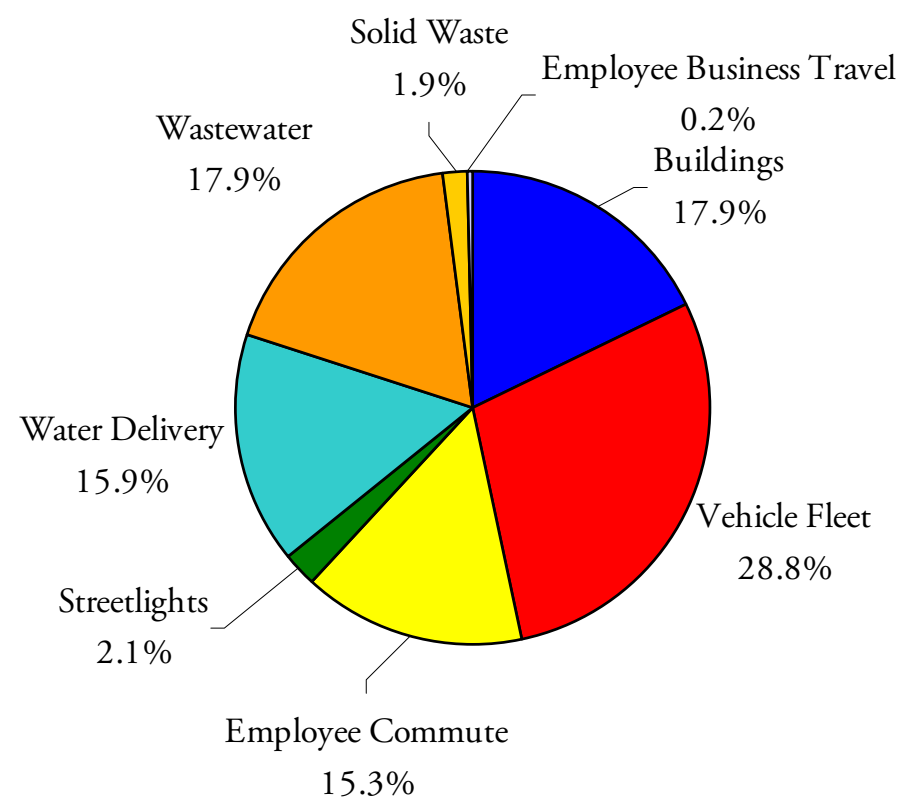

Emissions generated by the municipal operations of the City of San Luis Obispo are comprised of the fuel consumed by the municipal vehicle fleet and employee commute trips; energy consumption of buildings and facilities, water and wastewater facilities, and streetlights and traffic signals; and methane emissions from municipal solid waste sent to landfills. About 96 percent of those emissions were produced by the vehicle fleet, building and facilities, water delivery, wastewater, and employee commute sectors. As displayed in Figure 2, the vehicle fleet sector generated 1,898 $\mathrm{MTCO}_{2} \mathrm{e}$ emissions (28.8 percent), the buildings and facilities sector generated 1,178 $\mathrm{MTCO}_{2} \mathrm{e}$ emissions (17.9 percent), the wastewater sector generated $1,175 \mathrm{MTCO}_{2} \mathrm{e}$ emissions (17.9 percent), the water delivery sector generated 1,043 $\mathrm{MTCO}_{2}$ e emissions (15.9 percent), and the employee commute 
sector generated 1,009 $\mathrm{MTCO}_{2} \mathrm{e}$ emissions (15.3 percent). The remaining 3 percent of municipal emissions were generated from the other three sectors: the municipal solid waste sector generated $125 \mathrm{MTCO}_{2} \mathrm{e}$ emissions (1.9 percent), the streetlights and traffic signals sector generated 141 $\mathrm{MTCO}_{2} \mathrm{e}$ emissions (2.1 percent), and employee business travel sector generated $11 \mathrm{MTCO}_{2} \mathrm{e}$ emissions (0.2 percent). In 2005, the single largest generator of emissions was the city's water reclamation facility, which generated about 17.3 percent of all municipal emissions.

Municipal emissions are a subset of the total community emissions. This inventory analyzes municipal emissions separately in order to be able to identify energy cost-saving opportunities and emission reduction strategies appropriate for the community. The municipal operations inventory is guided by the Local Government Operations Protocol (Protocol), a recently published document that is designed to provide a standardized set of guidelines to assist local governments in quantifying and reporting greenhouse gas emissions associated with their government operations. The Protocol was developed jointly by the California Air Resources Board (CARB), ICLEI-Local Governments for Sustainability (ICLEI), California Climate Action Registry (CCAR), and The Climate Registry. The Protocol provides the principles, approach, methodology, and procedures needed to develop a municipal emissions inventory. An additional protocol for community emissions is currently being developed ${ }^{1}$.

\footnotetext{
${ }^{1}$ California Air Resources Board, AB 32 Scoping Plan, Sacramento, California, December 2008, page 27.
} 


\section{Forecast and Next Steps}

If consumption and growth trends continue based on those in 2005, emissions levels will reach 314,832 $\mathrm{MTCO}_{2}$ e by 2020, a 19.1 percent increase in emissions. This growth, shown in Figure 3, is due to projected increases in household, population, jobs, and transportation demand in the County ${ }^{2}$.

Figure 3: 2020 City of San Luis Obispo Business-As-Usual GHG Emissions Forecast

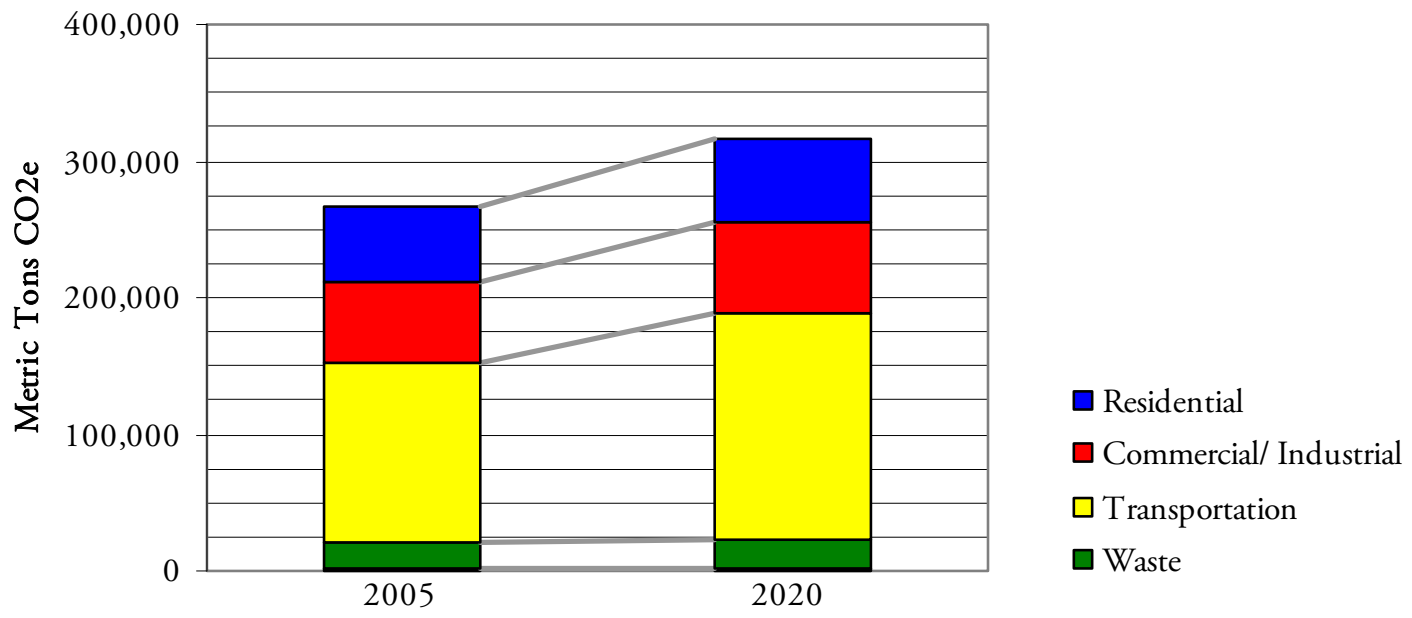

Given this information, the city can make a determination of a reduction target. In its recently approved AB 32 Scoping Plan, CARB encourages local governments to adopt a reduction goal for municipal operations emissions and to establish similar goals for community emissions that parallel the State's commitment to reduce emissions by 15 percent from current levels by $2020^{3}$. If the City were to conform to this recommended reduction of 15 percent below current levels (to an estimated

\footnotetext{
${ }^{2}$ See Chapter 6 (Forecast) for more information on the projected increases in emissions in each sector and an explanation of the source of data used to develop this projection.

${ }^{3}$ California Air Resources Board, AB 32 Scoping Plan, Sacramento, California, December 2008, page 27.
} 
$\left.224,601 \mathrm{MTCO}_{2} \mathrm{e}\right)$, it would require a reduction of 90,231 $\mathrm{MTCO}_{2} \mathrm{e}$ below the city's 2020

"business-as-usual” emissions (Figure 4), equivalent to a 40.2 percent reduction.

FIGURE 4: Greenhouse Gas Forecast

in relation to $15 \%$ Reduction Target (2005-2020)

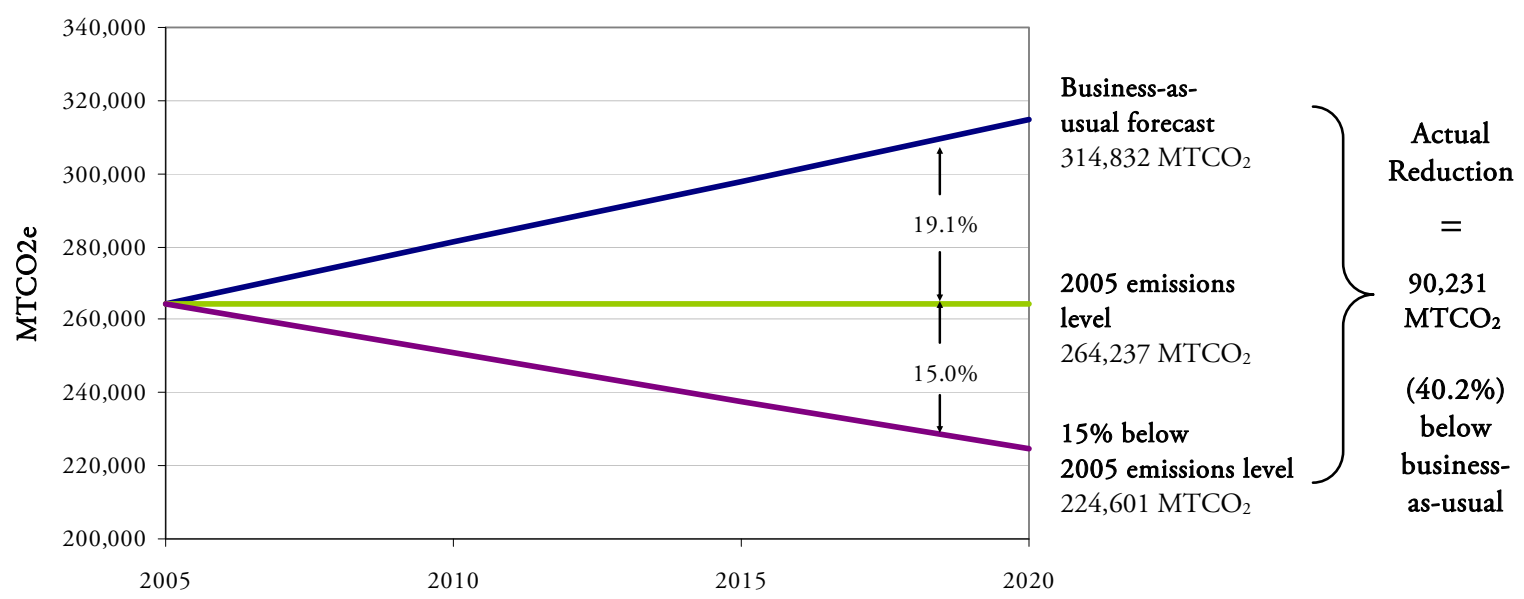

Data Limitations

A grant from the San Luis Obispo County Air Pollution Control District allowed for the funding of technical assistance from the consultant firm that prepared the San Luis Obispo County

\section{Community-wide and County Government Operations 2006 Baseline Greenhouse Gas Emissions}

Inventory. Technical assistance provided included developing consistent inventory methods and approaches to quantifying emissions for multiple jurisdictions in the County, as well as providing a peer-review of this emissions inventory.

After conferring with the consultant team, it was determined that existing reporting protocols for greenhouse gas emissions were insufficient at this time to accurately assign commercial air traffic's share of passengers who reside in the City of San Luis Obispo to the community inventory for the 
baseline year. A similar determination was made regarding passenger rail miles on the Amtrak rail service through San Luis Obispo.

The sources that could not be included due to privacy laws, lack of data availability, and/or a reasonable methodology include the following:

- Commercial air traffic attributable to residents from San Luis Obispo

- Passenger rail traffic attributable to residents from San Luis Obispo

- Freight traffic through San Luis Obispo

- Electricity usage for industrial businesses in San Luis Obispo (information was aggregated with the commercial use sector information)

- Vehicle mileage and fuel usage specific to each vehicle in the city's fleet; figures are instead aggregated for all vehicles

- Refrigerants from municipal facilities and vehicles

- Emissions from construction and demolition activities in San Luis Obispo

These limitations are explained further in this document. 


\section{Chapter 1: INTRODUCTION}

\subsection{Purpose of the study}

The purpose of this study is to inventory greenhouse gas emissions produced by the City of San Luis Obispo's government operations and the community-wide emissions from residents and businesses in San Luis Obispo. Reporting the City's emissions will aid policy makers in forecasting emission trends, identifying the point and mobile sources of emissions generated, and setting goals for future reductions and mitigation. Completion of the greenhouse gas emissions inventory represents the first milestone of ICLEI's Cities for Climate Protection campaign and fulfills a primary action of the U.S. Mayors Climate Protection Agreement.

\subsection{Climate change background}

Over the past 20 years, the extent, cause and impacts of global climate change have been debated with some uncertainty. However, more than 21,500 of the world's top climate scientists have reached consensus that global climate change is a human-created environmental and economic challenge of significant scope. According to the report "Climate Change 2007"- Working Group I Report: The Physical Science Basis of the Fourth Assessment Report prepared by more than 1,500 scientists of the Intergovernmental Panel on Climate Change (IPCC):

"Warming of the climate system is unequivocal, as is now evident from observations of increases in global average air and ocean temperatures, widespread melting of snow and ice, and rising global mean sea level" (IPCC, 2007). 
"Most of the observed increase in globally average temperatures since the mid $20^{\text {th }}$ century is very likely ${ }^{4}$ due to the observed increase in anthropogenic greenhouse gas concentrations" (IPCC, 2007).

"Continued greenhouse gas emissions at or above current rates would cause further warming and induce many changes in the global climate system during the $21^{\text {st }}$ century that would very likely be larger than those observed during the $20^{\text {th }}$ century" (IPCC, 2007).

The greenhouse effect is a natural phenomenon whereby certain gases in the earth's atmosphere, known as greenhouse gases, absorb heat that would otherwise escape to space. This heat originates from visible sunlight that warms the earth's surface. Subsequently, heat radiates from the surface to the atmosphere, where some of it is absorbed by greenhouse gases and radiated back to the surface, helping to maintain the surface temperatures and make Earth habitable. Some greenhouse gases occur naturally in the atmosphere, while others result from human activities. Naturally occurring greenhouse gases include water vapor, carbon dioxide, methane, nitrous oxide, and ozone. Recent progress in climate modeling has generated a consensus among climate scientists that greenhouse gases emitted by human activities are $l i k e l y^{5}$ to have caused most of the observed global temperature rise over the past fifty years ${ }^{6}$. Figure 1.1 illustrates the natural greenhouse effect on the left. Visible sunlight passes through the atmosphere without being absorbed. Some of the sunlight striking the earth is absorbed (1) and converted to infrared radiation (heat), which warms the surface. The

\footnotetext{
${ }^{4}$ The IPCC defines "very likely" as greater than 90 percent.

5 The IPCC defines "likely" as between 66 and 90 percent.

${ }^{6}$ Mitchell, et al. 2001. Detection of climate change and attribution of causes.
} 
surface emits infrared radiation to the atmosphere (2), where some of it is absorbed by the greenhouse gases (3) and redirected toward the surface (4). Some of the infrared radiation is not trapped by greenhouse gases and escapes into space (5). On the right side, the illustration shows how additional emissions generated into the atmosphere by human activities functions to increase the amount of infrared radiation that gets absorbed before escaping to space (6), which in turn enhances the greenhouse effect and amplifies the warming of the earth ${ }^{7}$.

\section{FIGURE 1.1: Illustration of greenhouse effect}

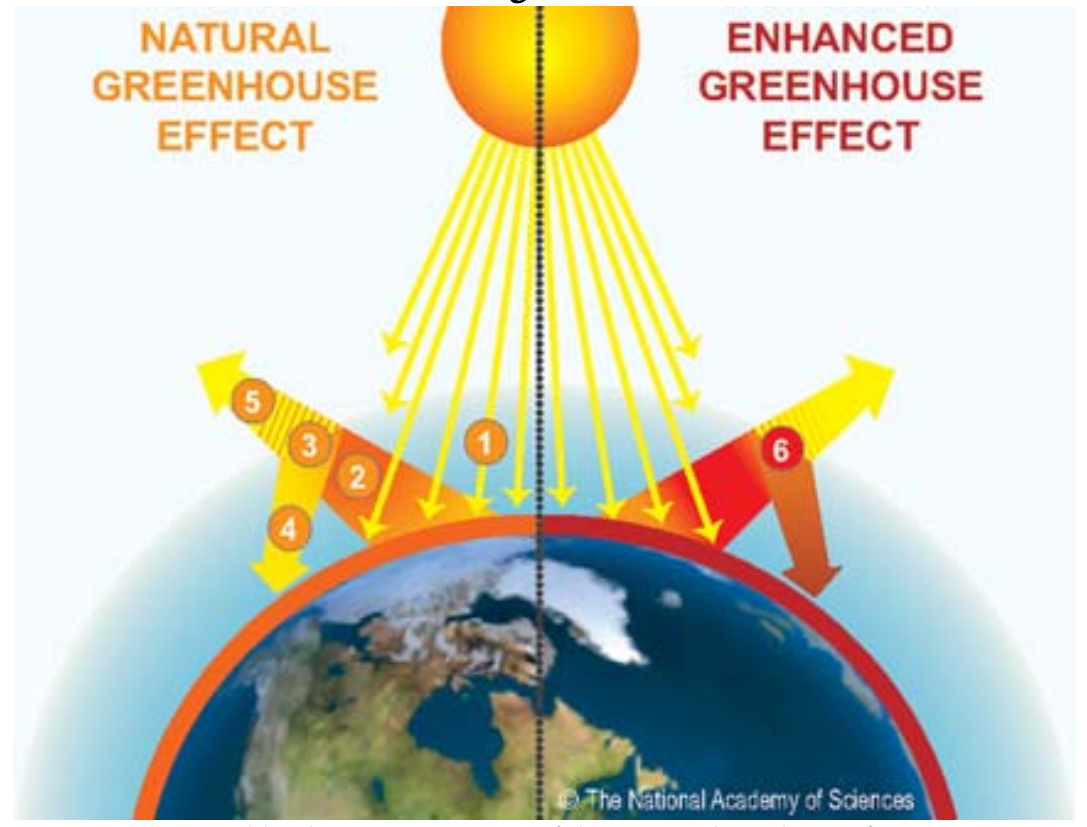

Source: Marian Kosbland Science Museum of the National Academy of Sciences

The rise of carbon dioxide gas in our atmosphere has been measured continuously since 1958 and follows an oscillating, upward line known as the "Keeling Curve" (see Figure 1.2). This measurement is named after Dr. Charles Keeling, who was the first to measure $\mathrm{CO}_{2}$ in the atmosphere on a continuous basis. Before the industrial era, research indicates atmospheric $\mathrm{CO}_{2}$

\footnotetext{
${ }^{7}$ Pew Center on Global Climate Change, The Causes of Global Climate Change, August 2008.
} 
concentration was between 275 and 280 parts per million by volume (ppmv) for several thousand years. Carbon dioxide has risen continuously since then, and the average value when Dr. Keeling started his measurements in 1958 was near 315 ppmv. By the year 2000 it had risen to about 367 ppmv, a one-third increase over the pre-industrial era ${ }^{8}$. As discussed above, as the concentration of atmospheric carbon dioxide and other greenhouse gases continues to rise, it lessens the ability of the earth's surface to radiate heat to space, accelerating the warming of the earth's surface.

FIGURE 1.2: Keeling Curve of atmospheric carbon dioxide (1958-2000)

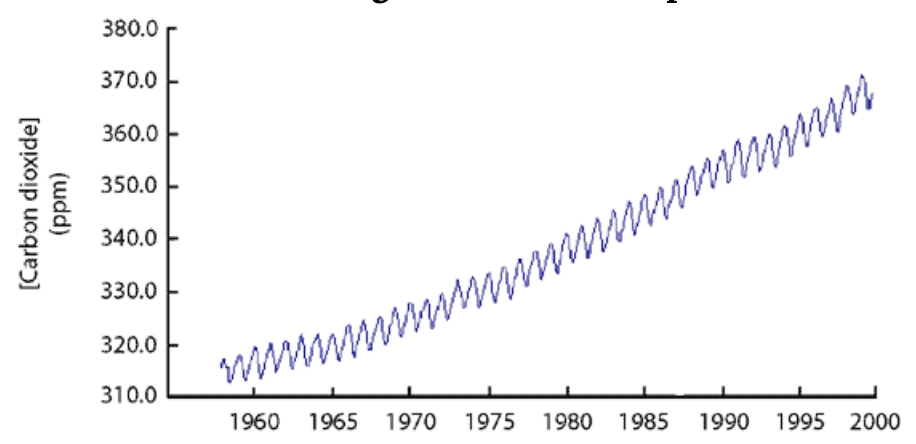

Source: University of California, San Diego

There are three greenhouse gases that are naturally occurring and three greenhouse gases that are not naturally occurring. Carbon dioxide, methane, and nitrous oxide are the three naturallyoccurring greenhouse gases. Carbon dioxide $\left(\mathrm{CO}_{2}\right)$ is released to the atmosphere when solid waste, fossil fuels (oil, natural gas, and coal), and wood and wood products are burned. Methane $\left(\mathrm{CH}_{4}\right)$ is emitted during the production and transport of coal, natural gas, and oil. Methane emissions also result from the decomposition of organic waste in municipal solid waste landfills, and the raising of

\footnotetext{
${ }^{8}$ University of California, San Diego: http://earthguide.ucsd.edu/globalchange/keeling curve/01.html
} 
livestock. Nitrous oxide $\left(\mathrm{N}_{2} \mathrm{O}\right)$ is emitted during agricultural and industrial activities, as well as during combustion of solid waste and fossil fuels? .

Very powerful greenhouse gases, also known as high global warming potential (GWP) gases that are not naturally-occurring, including hydrofluorocarbons (HFCs), perfluorocarbons (PFCs), and sulfur hexafluoride $\left(\mathrm{SF}_{6}\right)$, are generated in a variety of industrial processes. Each of the six greenhouse gases (the three naturally occurring and the three listed here) differs in its ability to absorb heat in the atmosphere. High GWP gases such as HFCs, PFCs, and $\mathrm{SF}_{6}$ are the most heat-absorbent. For example, methane traps over 21 times more heat per molecule than carbon dioxide, and nitrous oxide absorbs 310 times more heat per molecule than carbon dioxide. For the purposes of a greenhouse gas emissions inventory, greenhouse gas emissions are presented in carbon dioxide equivalents, which weight each gas by its GWP. Table 1.1 shows the global warming potentials for different greenhouse gases for a 100 -year time horizon ${ }^{10}$.

TABLE 1.1: Global warming potentials for greenhouse gases

\begin{tabular}{|c|c|}
\hline Greenhouse Gas & Global Warming Potential \\
\hline $\mathrm{CO}_{2}$ (carbon dioxide) & 1 \\
\hline $\mathrm{CH}_{4}$ (methane) & 21 \\
\hline $\mathrm{N}_{2} \mathrm{O}$ (nitrous oxide) & 310 \\
\hline $\mathrm{HFCs}$ (hydrofluorocarbons) & $140-11,700$ \\
\hline $\mathrm{PFCs}_{\text {(perfluorocarbons) }}$ & $6,500-9,200$ \\
\hline $\mathrm{SF}_{6}$ (sulfur hexafluoride) & 23,900 \\
\hline
\end{tabular}

Source: Intergovernmental Panel on Climate Change (IPCC) Second Assessment Report (1995)

\subsection{Greenhouse gas inventories}

The greenhouse gas inventory process is relatively new. Greenhouse gas inventories originated as an international response to mitigate global climate change. Fundamentally, a greenhouse gas

${ }^{9}$ IPCC, Working Group I Report: The Physical Science Basis of the Fourth Assessment Report, 2007.

${ }^{10}$ Ibid. 
inventory measures the amount of heat-trapping gases that an entity contributes to the atmosphere.

By quantifying emissions, an entity can identify a starting place or benchmark to understand where future efforts will have the greatest impact to reduce areas of higher emissions.

Each year, the U.S. Environmental Protection Agency (U.S. EPA) prepares a national greenhouse gas inventory report. The 2008 report, which estimates U.S. greenhouse gas emissions and sinks ${ }^{11}$ for the years 1990-2006, defines a greenhouse gas inventory:

"A greenhouse gas inventory is an accounting of the amount of greenhouse gases emitted to or removed from the atmosphere over a specific period of time (e.g., one year). A greenhouse gas inventory also provides information on the activities that cause emissions and removals, as well as background on the methods used to make the calculations. Policy makers use greenhouse gas inventories to track emission trends, develop strategies and policies and assess progress. Scientists use greenhouse gas inventories as inputs to atmospheric and economic models" (U.S. EPA, 2008).

With the passage of AB 4420 (Sher, Chapter 1506, Statutes of 1988), the California Energy Commission (CEC) was directed to study global warming impacts to the state and develop an inventory of greenhouse gas emissions sources. The first greenhouse gas emissions inventory for the State of California was published in October 1990 by the CEC, covering only one year (1988) and

\footnotetext{
${ }^{11}$ Greenhouse gas sinks, also known as "carbon sinks", are any physical unit or process that stores greenhouse gas emissions; the process of absorbing greenhouse gas emissions is commonly referred to as carbon sequestration, which may occur by way of conservation of riparian buffers, grazing land management, forest preservation, or tree planting (Ravin, A., and T. Raine. Best Practices for Including Carbon Sinks in Greenhouse Gas Inventories.)
} 
only provided an inventory of $\mathrm{CO}_{2}{ }^{12}$. The second statewide inventory of greenhouse gas emissions was published in March 1997 and was also only for one year (1990) but included an estimate for methane and nitrous oxide emissions in addition to $\mathrm{CO}_{2}{ }^{13}$. In January 1998, the CEC published a five-year inventory covering years 1990 through $1994^{14}$. In 2000, Senate Bill 1771 (Sher, Chapter 1018, Statutes of 2000) was passed, requiring the CEC to update the inventory in January 2002 and every five years after that. The first statewide inventory developed under SB 1771, titled Inventory of California Greenhouse Gas Emissions and Sinks: 1990-1999 was developed following the guidance set forth by the IPCC and was consistent with the methods used by the U.S. EPA. The most recent statewide inventory completed by the CEC, the Inventory of California Greenhouse Gas Emissions and Sinks: 1990-2004, estimates California produced 492 million metric tons of greenhouse gas emissions in $2004^{15}$.

In January 2007, Assembly Bill 1803 transferred responsibility for developing and maintaining the State's greenhouse gas inventory from the CEC to the California Air Resources Board (CARB). Using the CEC's most recent inventory as a starting point, CARB determined the State's 1990 greenhouse gas emissions level by conducting a comprehensive review of all greenhouse gas-emitting sectors to comply with the requirements of AB 32 (discussed below). CARB determined the 1990 total statewide emissions estimate to be the same identified in the CEC's inventory, but found

\footnotetext{
${ }^{12}$ California Energy Commission, 1988 Inventory of California Greenhouse Gas Emissions, Sacramento, California, Final Staff Report, October 1990.

${ }^{13}$ California Energy Commission, California's Greenhouse Gas Emissions Inventory 1990, Sacramento, California, P50097-004, March 1997.

${ }^{14}$ California Energy Commission, Appendix A. Historical and Forecasted Emissions Inventories for California, Sacramento, California, P500-98-011V3, January 1998.

${ }^{15}$ California Energy Commission, Inventory of California Greenhouse Gas Emissions and Sinks: 1990-2004, Sacramento, California, CEC-600-2006-013-SF, December 2006.
} 
differing emissions within each sector of the inventory. According to this inventory, the estimated statewide emissions for 1990 are 427 million metric tons of carbon dioxide equivalents $\left(\mathrm{MMTCO}_{2} \mathrm{e}\right)$, while the estimated statewide emissions for 2004 are $484 \mathrm{MMTCO}_{2} \mathrm{e}^{16}$. The preliminary statewide emissions estimate for 2020, assuming no emission-reduction measures are taken, is $596 \mathrm{MMTCO}_{2} \mathrm{e}$. The difference between the proposed 1990 emissions level and ARB's preliminary estimate of 2020 emissions is therefore $169 \mathrm{MMTCO}_{2} \mathrm{e}^{17}$.

\subsection{Evolving federal climate action policy}

Until recently, limited decisive action has been taken at the federal level to address climate change and the reduction of greenhouse gas emissions. In the last two years, several pieces of legislation have been proposed to establish targets for the reduction of greenhouse gas emissions. Proposed legislation includes incremental reductions of greenhouse gas emissions over a long time-horizon by instituting a "cap-and-trade" system for greenhouse gas emissions. Although each piece of legislation varies, proposed emission reductions range from at or below 2005 levels by 2012, up to 20 percent below 2005 levels by 2020, and up to 80 percent below 2005 levels by 2050. Under a federal cap-and-trade system, the federal government would auction off emissions allowances to emitters, as well as distributing emissions allowances to specified recipients, such as public transit agencies, which could then be sold. The total amount of emissions allowances available to emitters would decline each year in order to reach the target reductions set forth in the legislation ${ }^{18}$.

\footnotetext{
${ }^{16}$ California Air Resources Board, California 1990 Greenhouse Gas Emissions Level and 2020 Emissions Limit, Staff Report, November 2007.

${ }^{17}$ California Air Resources Board, AB 32 Scoping Plan, Sacramento, California, December 2008.

${ }^{18}$ Pew Center on Global Climate Change, The Causes of Global Climate Change, August 2008.
} 
In May 2009, a national fuel efficiency standard was established for all new passenger vehicles and non-commercial trucks sold in the United States. The new standards cover model years 2012 through 2016 and ultimately require an average fuel economy standard of $35.5 \mathrm{mpg}$ in 2016 . This action surpasses the Corporate Average Fuel Economy standards passed in 2007, which required an average fuel economy of $35 \mathrm{mpg}$ in 2020 . The new fuel economy standard is projected to save 1.8 billion barrels of oil over the life of the program, and would lead to a reduction of approximately 900 million metric tons of greenhouse gas emissions ${ }^{19}$.

\subsection{Climate action at the state level}

The State of California has established itself as a leader in climate policy. In 2005, Governor Schwarzenegger issued Executive Order S-3-05, which established three aggressive deadlines and targets to achieve greenhouse gas emissions reductions. Those goals are as follows:

- By 2010, reduce greenhouse gas emissions to 2000 levels;

- By 2020, reduce greenhouse gas emissions to 1990 levels;

- By 2050, reduce greenhouse gas emissions to 80 percent below 1990 levels.

To allow for the implementation of these aggressive goals, in 2006, the Legislature passed and Governor Schwarzenegger signed AB 32, the California Global Warming Solutions Act of $2006^{20}$, which codified the 2020 greenhouse gas emissions reduction goals into law. One of the primary objectives of $\mathrm{AB} 32$ is to reduce statewide greenhouse gas emissions to 1990 emissions levels by 2020. The law directed CARB to begin developing discrete early actions to reduce greenhouse gases

\footnotetext{
${ }^{19}$ White House Press Release, "President Obama Announces National Fuel Efficiency Policy”, May 19, 2009.

${ }^{20}$ The California Global Warming Solutions Act of 2006 is commonly known as AB 32 (Nunez and Pavley, Chapter 488, Statutes of 2006).
} 
while also preparing a scoping plan to identify how best to reach the 2020 reduction goals. The reduction measures to meet the 2020 target will go into effect in 2012. There are a number of specific requirements for $\mathrm{CARB}$ under $\mathrm{AB} 32$, one of which states: "Ensure early voluntary reductions receive appropriate credit in the implementation of AB 32." The AB 32 Scoping Plan was approved in December 2008 with a set of proposed measures and more specific targets for emission reductions in various sectors in order to attempt to achieve the 1990 emissions levels of 427 $\mathrm{MMTCO}_{2} \mathrm{e}$ by 2020. For example, the AB 32 Scoping Plan estimates the potential reduction of emissions from the Green Building sector to be $26 \mathrm{MMTCO}_{2} \mathrm{e}^{21}$.

Other significant pieces of state legislation shaping climate action planning in California include SB 97, SB 375, and SB 1078. SB 97 (Dutton, Chapter 185, Statutes of 2007) requires the Governor's Office of Planning and Research to develop guidelines for addressing climate change in CEQA documents (guidelines are to be approved in 2010). SB 375 (Steinberg, Chapter 728, Statutes of 2008) is a complex piece of legislation intended to align separate processes of land use planning, transportation planning, and the regional housing allocation process, while providing CEQA stream-lining for certain projects in an effort to reduce emissions from the transportation sector. SB 1078 (Sher, Chapter 516, Statutes of 2002), the California Renewables Portfolio Standard requires utility providers to increase their renewable energy portfolio by at least 1 percent of their retail sales each year until they reach 20 percent in 2010 .

\footnotetext{
${ }^{21}$ California Air Resources Board, AB 32 Scoping Plan, Sacramento, California, December 2008.
} 


\subsection{Climate action at the local level}

While international and national efforts to mitigate global climate change are evolving, many cities and counties across the country and around the world have initiated local greenhouse gas emissions studies and programs to reduce emissions. "Bottom-up" initiatives are taking root and growing rapidly in local communities. Lasting reductions in greenhouse gas emissions are possible however when individuals, organizations and energy producers change their behavior and activities, and employ different technologies, something that can be initiated through local action.

Monitoring greenhouse gas emissions is the critical first step to setting a goal for emissions reductions, developing policies and programs to achieve that goal, and measuring progress toward reductions. This report represents the first comprehensive effort to quantify greenhouse gas emissions generated by the municipal operations of the City of San Luis Obispo and those generated by the community at-large.

On February 16, 2005 the Kyoto Protocol, the international agreement to address climate change, became law for the 141 countries that had ratified it to date. On that same day, Seattle Mayor Greg Nickels launched an initiative called the U.S. Mayors Climate Protection Agreement to advance the goals of the Kyoto Protocol through leadership and action by at least 141 American cities $^{22}$. The City of San Luis Obispo signed the U.S. Mayors Climate Protection Agreement which states:

${ }^{22}$ U.S. Mayors Climate Protection Agreement, http://www.usmayors.org/climateprotection/agreement.htm. 
"We urge the federal government and state governments to enact policies and programs to meet or beat the target of reducing global warming pollution levels to 7 percent below 1990 levels by $2012 \ldots$

“... we will strive to meet or exceed Kyoto Protocol targets for reducing global warming pollution by taking actions in our own operations and communities such as:

(1) Inventory global warming emissions in City operations and in the communities, set reduction targets and create an action plan;

(2) Adopt and enforce land-use policies that reduce sprawl, preserve open space, and create compact, walkable urban communities;

(3) Promote transportation options such as bicycle trails, commute trip reduction programs, incentives for car-pooling and public transit...”

- The U.S. Mayors Climate Protection Agreement (2005)

The goal of 141 signatories was reached by June 2005, at the annual U.S. Conference of Mayors Annual Meeting. As of May 2009, 944 mayors from the fifty states, the District of Columbia and Puerto Rico have signed the agreement, representing a population of over 81 million citizens ${ }^{23}$. In California alone, 122 cities to date have signed the agreement. Atascadero and Morro Bay are the other cities in San Luis Obispo County that have signed the agreement. The full text of the agreement is in Appendix D.

${ }^{23}$ U.S. Mayors Climate Protection Agreement, http://usmayors.org/climateprotection/. 
In 1993, at the invitation of ICLEI-Local Governments for Sustainability ${ }^{24}$, municipal leaders met at the United Nations Headquarters in New York and adopted a declaration that called for the establishment of a worldwide movement of local governments to reduce greenhouse gas emissions, improve air quality, and enhance urban sustainability. The resulting Cities for Climate Protection (CCP) campaign now includes nearly 6,000 local governments worldwide that are integrating climate change mitigation into their decision-making processes.

The City of San Luis Obispo adopted a resolution to join ICLEI and the CCP campaign in spring 2008. The CCP campaign provides a framework for local communities to identify and reduce greenhouse gas emissions, and is organized along five milestones:

1. Conduct a baseline emissions inventory and forecast

2. Set an emissions reduction target

3. Develop an action plan to meet the emissions reduction target

4. Implement the action plan

5. Monitor and verify progress and results.

This report represents the completion of the first CCP milestone, and provides a foundation for future work to reduce greenhouse gas emissions in San Luis Obispo. Milestones 2 through 5 are explained in Chapter 7. Additionally, a list of tangible actions the City has already undertaken to conserve energy and support energy efficiency is provided in section 7.5.

\footnotetext{
${ }^{24}$ The International Council on Local Environmental Initiatives was recently renamed ICLEI-Local Governments for Sustainability.
} 


\section{Chapter 2: REVIEW OF CURRENT PRACTICE}

\subsection{Introduction and overview}

Due to limited peer-reviewed literature on the development of the local greenhouse gas emissions inventory, a review of current practice was completed to understand the state of the practice, organization of the inventory, emissions sectors measured at the community-level and municipallevel, identify potential data sources, and the methodology for quantifying emissions for each sector.

This review of current practice included jurisdictions that have the following characteristics: (a) is a small- or medium-sized city in California, (b) has recently completed a greenhouse gas emissions inventory, (c) completed an inventory that includes both a community and municipal inventory, and (d) the inventory document and all appendices are available online. The jurisdictions selected for the review include: Benicia (Sonoma County), Berkeley and Hayward (Alameda County), Chico (Butte County), Davis (Yolo County), Menlo Park (San Mateo County), Pittsburg (Contra Costa County), and Santa Cruz (Santa Cruz County). Table 2.1 provides an overview of the eight jurisdictions that were included in this review including total community-wide emissions for each jurisdiction.

All but one jurisdiction developed an emissions inventory for the year 2005. In the case of Davis, the baseline year used for the emissions inventory was 1990. In many cases, 2005 was selected as the baseline year due to data availability in general and having data available in an electronic format. 
TABLE 2.1: Summary results of greenhouse gas inventories of selected California cities

\begin{tabular}{|c|c|c|c|c|c|}
\hline Jurisdiction & $\begin{array}{c}\text { Publication } \\
\text { Year }^{(a)}\end{array}$ & $\begin{array}{c}\text { Inventory } \\
\text { Year }^{(b)}\end{array}$ & $\begin{array}{c}\text { Population } \\
\text { (in inventory year) }\end{array}$ & $\begin{array}{c}\text { Community- } \\
\text { wide emissions }{ }^{(\mathrm{d})}\end{array}$ & $\begin{array}{c}\text { GHG per capita } \\
\text { (estimate) }\end{array}$ \\
\hline Benicia & 2008 & 2005 & 27,154 & $4,247,875$ & 156.4 \\
\hline Berkeley & 2007 & 2005 & 104,115 & 634,797 & 6.1 \\
\hline Chico & 2008 & 2005 & 73,657 & 610,951 & 8.3 \\
\hline Davis & 2008 & 1990 & 64,553 & 225,200 & 3.5 \\
\hline Hayward & 2008 & 2005 & 145,416 & $1,279,438$ & 8.8 \\
\hline Menlo Park & 2007 & 2005 & 30,549 & 487,888 & 16.0 \\
\hline Pittsburg (e) & 2009 & 2005 & 62,172 & $4,394,214$ & 70.7 \\
\hline Santa Cruz & 2008 & 2005 & 56,393 & 327,635 & 5.8 \\
\hline
\end{tabular}

Sources: City of Benicia Greenhouse Gas Emissions Inventory Report, Amalia Lorentz and Kathleen Hart, September 2008; City of Berkeley Baseline Greenhouse Gas Emissions Inventory Report, ICLEI and Neal DeSnoo, April 2007; City of Chico Community and Municipal Greenhouse Gas \& Criteria Air Pollutant Emissions Inventory, Daniel Salazar, April 2008; City of Davis Greenhouse Gas Inventory \& Forecast Report, Christa Clark Jones, March 2008; City of Hayward Baseline Greenhouse Gas Emissions Inventory Report, ICLEI and Vera Dahle-Lacaze, June 2008; City of Menlo Park Greenhouse Gas Emissions Analysis, Micah Lang, November 2007; City of Pittsburg Greenhouse Gas Emissions Baseline Inventory and Analysis, Miya Kitahara, October 2009; City of Santa Cruz Greenhouse Gas Emissions Inventory 2005 Municipal and Community Emissions, Ross Clark and Charlie Lewis, August 2008.

Notes:

(a) "Publication Year" refers to year of adoption and publication of inventory document

(b) "Inventory Year" refers to year selected for jurisdiction's baseline emissions inventory

(c) Population figures from California Department of Finance

(d) Emissions in metric tons of carbon dioxide equivalents $\left(\mathrm{MTCO}_{2} \mathrm{e}\right)$

(e) The Pittsburg inventory is presented in two ways - with and without industrial emissions and regional transportation. When not including emissions from these regional sources, the inventory total is 235,668 $\mathrm{MTCO}_{2} \mathrm{e}$.

The sectors that are included in each of the emissions inventory include the following: residential, commercial, industrial, transportation, and solid waste. Table 2.2 provides a summary of the sectors that are included in each of the inventories reviewed. It is common for jurisdictions that do not have a significant industrial presence to combine industrial emissions with commercial emissions. The inventory for Pittsburg separates commercial and industrial emissions. Five of the eight jurisdictions combined commercial and industrial emissions, while the Chico and Menlo Park inventories did not report on emissions from the industrial sector. 
TABLE 2.2: Sectors included in community emissions inventory

\begin{tabular}{|l|c|c|c|c|c|c|c|}
\hline Jurisdiction & Residential & Commercial & Industrial & $\begin{array}{c}\text { Commercial } \\
\text { / Industrial }\end{array}$ & Transportation & Waste & Other \\
\hline Benicia & $\mathrm{X}$ & & & $\mathrm{X}$ & $\mathrm{X}$ & $\mathrm{X}$ & \\
\hline Berkeley & $\mathrm{X}$ & & & $\mathrm{X}$ & $\mathrm{X}$ & & \\
\hline Chico & $\mathrm{X}$ & $\mathrm{X}$ & & & $\mathrm{X}$ & $\mathrm{X}$ & \\
\hline Davis & $\mathrm{X}$ & & & $\mathrm{X}$ & $\mathrm{X}$ & $\mathrm{X}$ & \\
\hline Hayward & $\mathrm{X}$ & & & $\mathrm{X}$ & $\mathrm{X}$ & $\mathrm{X}$ & \\
\hline Menlo Park & $\mathrm{X}$ & $\mathrm{X}$ & & & $\mathrm{X}$ & $\mathrm{X}$ & Landfill \\
\hline Pittsburg & $\mathrm{X}$ & $\mathrm{X}$ & $\mathrm{X}$ & & $\mathrm{X}$ & $\mathrm{X}$ & \\
\hline Santa Cruz & $\mathrm{X}$ & & & $\mathrm{X}$ & $\mathrm{X}$ & $\mathrm{X}$ & \\
\hline
\end{tabular}

Source: Author's review of inventory documents of selected California cities

The eight inventories are developed in a similar framework and include many of the same sectors in each respective inventory. When the inventories are compared in terms of emissions per capita attributable to each sector, the inventories are found to be dissimilar for most of the sectors measured. Table 2.3 provides a comparison of per capita emissions for the eight inventories. In Benicia and Pittsburg, nearly all emissions are generated by the industrial sector. For this reason, Pittsburg presented the community inventory in two levels - with and without "regional sources". In the Pittsburg inventory, "regional sources" included emissions from three natural gas power plants, a petroleum coke plant, and vehicle-miles of travel (VMT) on state highways that travel through the city.

In each of the sectors, emissions per capita are noticeably higher in the Menlo Park inventory. As an example, residential emissions per capita range between 1.20 and 1.62 metric tons for the other 2005 community inventories, while residential emissions per capita is 2.79 metric tons in Menlo Park. 
TABLE 2.3: Comparison of per capita emissions by sector for selected inventories

\begin{tabular}{|c|c|c|c|c|c|c|c|c|}
\hline \multirow{2}{*}{ Jurisdiction } & \multirow{2}{*}{$\begin{array}{c}\text { Total } \\
\text { GHG } \\
\text { emissions } \\
\text { per } \\
\text { capita }^{(a)}\end{array}$} & \multicolumn{7}{|c|}{$\begin{array}{c}\text { Emissions per capita by sector } \\
\text { (metric tons of carbon dioxide equivalents) }\end{array}$} \\
\hline & & Res. & Comm. & Ind. & $\begin{array}{l}\text { Comm. } \\
\text { \& Ind. }{ }^{(b)}\end{array}$ & Transport & Waste & Other \\
\hline Benicia & 156.4 & 1.51 & -- & - & 148.28 & 5.83 & 0.81 & - \\
\hline Berkeley & 6.1 & 1.62 & -- & -- & 1.67 & 2.81 & - & - \\
\hline Chico & 8.3 & 1.62 & 1.88 & 0.01 & -- & 4.52 & 0.27 & -- \\
\hline Davis & 3.5 & 0.82 & -- & -- & 0.72 & 2.04 & -0.10 & -- \\
\hline Hayward & 8.8 & 1.20 & -- & - & 1.81 & 5.56 & 0.23 & -- \\
\hline Menlo Park & 16.0 & 2.79 & 3.88 & - & -- & 7.36 & 0.57 & 1.37 \\
\hline Pittsburg $^{(c)}$ & 70.7 & 1.20 & 1.15 & 64.09 & -- & 3.86 & 0.38 & -- \\
\hline Pittsburg $^{(\mathrm{d})}$ & 3.8 & 1.20 & 1.15 & 0.00 & -- & 1.06 & 0.38 & -- \\
\hline Santa Cruz & 5.8 & 1.33 & -- & -- & 1.47 & 2.79 & 0.22 & -- \\
\hline
\end{tabular}

Source: Author's review of inventory documents of selected California cities

Notes:

(a) The population used for this calculation is found in Table 2.1; it is the jurisdiction's population in the inventory year published by the California Department of Finance.

(b) Commercial and Industrial sectors are combined in the inventories for Benicia, Berkeley, Davis, Hayward, and Santa Cruz. No energy data is collected for the industrial sector in the inventory year for Menlo Park.

(c) Pittsburg presented the community-wide inventory in two ways - an inventory that includes emissions from regional sources and an inventory that does not include emissions from regional sources; these figures include Industrial emissions and emissions from "Regional Transportation".

(d) These figures do not include Industrial emissions and emissions from "Regional Transportation"

The Benicia and Pittsburg inventories report very high per capita industrial emissions, which underscores the significant industrial presence in each of those cities in relation to the relatively low population of the respective cities.

Per capita transportation emissions consistently represent the highest sector for each of the communities, ranging between $2.04 \mathrm{MTCO}_{2}$ e per capita (Davis) and 7.36 $\mathrm{MTCO}_{2}$ e per capita (Menlo Park). A comparison of per capita "regional" transportation emissions $\left(3.86 \mathrm{MTCO}_{2} \mathrm{e}\right)$ and per capita "local" transportation emissions $\left(1.06 \mathrm{MTCO}_{2} \mathrm{e}\right)$ in Pittsburg underscores the importance of defining what VMT should be attributable to a given community. The Pittsburg inventory classifies VMT on state highways through the community as "regional" transportation and VMT on 
city streets as "local" transportation. As will be discussed in section 2.3.3, at this time it is common practice for community inventories to include VMT on highways that pass through the jurisdiction.

\subsection{Organization for local emissions inventory}

In the survey of the emissions inventories for the eight jurisdictions, several questions related to the overall organization of the inventory documents, such as the preparation of the inventory, what accounting software was used, whether or not the jurisdiction joined ICLEI or worked under a separate framework, and whether or not the inventory was prepared as a single jurisdiction or as part of multi-jurisdictional effort. Other questions in the survey focused on how the communities compare to one another in terms of the presence of major facilities, such as the presence of a college or university campus, or major industrial sources; as well as how the baseline year of the inventory was established.

\subsubsection{Preparation of emissions inventory}

Of the eight inventories surveyed, four were prepared by city staff. The municipal operations emissions inventory of Berkeley was prepared by an energy officer employed by the city, while its community emissions inventory was prepared by ICLEI staff. The inventories for Menlo Park and Hayward were prepared by ICLEI staff, while the inventory for Chico was prepared by a consultant (see Table 2.4). 
TABLE 2.4: Preparation of emissions inventory

\begin{tabular}{|c|c|c|c|}
\hline Jurisdiction & $\begin{array}{l}\text { Inventory prepared by } \\
\text { consultant or city staff }\end{array}$ & $\begin{array}{l}\text { Citizen task force } \\
\text { established as part of the } \\
\text { inventory process }\end{array}$ & $\begin{array}{c}\text { Inventory prepared } \\
\text { independently or as part of } \\
\text { a multi-jurisdictional effort }\end{array}$ \\
\hline Benicia & $\begin{array}{l}\text { Prepared by city staff } \\
\text { (City Manager's Office, } \\
\text { assistance provided by ICLEI } \\
\text { staff) }\end{array}$ & No & Single jurisdiction \\
\hline Berkeley & $\begin{array}{l}\text { Community inventory } \\
\text { prepared by ICLEI staff; } \\
\text { municipal inventory prepared } \\
\text { by city staff (energy officer) }\end{array}$ & No & $\begin{array}{l}\text { Multiple jurisdictions } \\
\text { (Alameda County Climate } \\
\text { Protection Project) } \\
{[10 \text { cities in county joined }} \\
\text { CCP campaign] }\end{array}$ \\
\hline Chico & Prepared by consultant & $\begin{array}{l}\text { Yes, } 1 \text { citizen task force } \\
\text { formed } \\
\text { (Sustainability Task Force) }\end{array}$ & Single jurisdiction \\
\hline Davis & $\begin{array}{l}\text { Prepared by city staff } \\
\text { (Public Works Department) }\end{array}$ & $\begin{array}{l}\text { Yes, } 2 \text { citizen task forces } \\
\text { formed } \\
\text { (Climate Action Team, } \\
\text { Science Advisory Team) }\end{array}$ & Single jurisdiction \\
\hline Hayward & $\begin{array}{l}\text { Prepared by ICLEI staff } \\
\text { (assistance provided by city } \\
\text { staff and Alameda County } \\
\text { Waste Management } \\
\text { Authority) }\end{array}$ & No & $\begin{array}{l}\text { Multiple jurisdictions } \\
\text { (Alameda County Climate } \\
\text { Protection Project) } \\
{[10 \text { cities in county joined }} \\
\text { CCP campaign] }\end{array}$ \\
\hline Menlo Park & Prepared by ICLEI staff & $\begin{array}{l}\text { Yes, } 1 \text { citizen task force } \\
\text { formed to work on set of } \\
\text { recommendations for climate } \\
\text { action plan } \\
\text { (Green Ribbon Committee) }\end{array}$ & Single jurisdiction \\
\hline Pittsburg & $\begin{array}{l}\text { Prepared by city staff } \\
\text { (Public Works Department } \\
\text { intern) }\end{array}$ & No & $\begin{array}{l}\text { Multiple jurisdictions } \\
\text { (Contra Costa County } \\
\text { Climate Leaders }(4 \mathrm{CL})) \\
\text { [16 cities in county joined } \\
\text { CCP campaign] }\end{array}$ \\
\hline Santa Cruz & $\begin{array}{l}\text { Prepared by city staff } \\
\text { (Green Building } \\
\text { Coordinator) }\end{array}$ & $\begin{array}{l}\text { Yes, } 1 \text { city-level } \\
\text { interdepartmental task force } \\
\text { formed } \\
\text { (Climate Action Workgroup) }\end{array}$ & $\begin{array}{l}\text { Multiple jurisdictions } \\
\text { (County, City and UCSC } \\
\text { formed "Climate Action } \\
\text { Compact") }\end{array}$ \\
\hline
\end{tabular}

Source: Author's review of inventory documents of selected California cities

Three of the eight cities formed a citizen task force to assist in the preparation of the emissions inventory. Two task forces (Climate Action Team and Science Advisory Team) were formed in Davis, while one task force each was formed in Chico (Sustainability Task Force) and Menlo Park (Green Ribbon Committee). In Santa Cruz, an interdepartmental task force was formed (Climate 
Action Workgroup) consisting of city staff from several departments. The other four cities (Benicia,

Berkeley, Hayward, and Pittsburg) did not form a citizen's task force as part of the preparation of the emissions inventory.

Three of the eight jurisdictions surveyed completed inventories concurrently with other jurisdictions within their respective county. The inventories for Berkeley and Hayward were completed as part of the Alameda County Climate Action Project, which included ten cities. Pittsburg completed the inventory while joining the Contra Costa County Climate Leaders (4CL) along with 15 other cities. The City of Santa Cruz partnered with the County of Santa Cruz and UC Santa Cruz to form the "Climate Action Compact", with the intention of each entity developing a separate emissions inventory. The other four inventories (Benicia, Chico, Davis, and Menlo Park) were completed independently without joining a larger countywide or multi-jurisdictional effort.

\subsubsection{Framework of emissions inventory}

All eight inventories surveyed indicated that the jurisdictions each joined ICLEI - Local Governments for Sustainability (ICLEI). ICLEI (founded in 1990) initiated the Cities for Climate Protection (CCP) campaign in 1993. Local governments that become members of this campaign pledge to reduce greenhouse gas emissions by a locally determined amount and to develop a local action plan. All eight jurisdictions joined ICLEI and developed their respective inventory document under the framework of the CCP campaign (see Table 2.5). Additionally, all eight jurisdictions used the Clean Air Climate Protection software to produce the emissions inventory. The CCP campaign and emissions accounting software allow for standardization in the development of the local 
emissions inventory as well as allowing for some level of comparability of emissions inventories

throughout California.

TABLE 2.5: Framework for emissions inventory and emissions software used

\begin{tabular}{|l|l|l|}
\hline Jurisdiction & $\begin{array}{c}\text { Jurisdiction joined ICLEI and developed } \\
\text { inventory under framework of Cities for } \\
\text { Climate Protection Campaign? }\end{array}$ & \multicolumn{1}{|c|}{$\begin{array}{c}\text { Emissions accounting software used for } \\
\text { inventory }\end{array}$} \\
\hline Benicia & Yes & Clean Air Climate Protection software \\
\hline Berkeley & Yes & Clean Air Climate Protection software \\
\hline Chico & Yes & Clean Air Climate Protection software \\
\hline Davis & Yes & Clean Air Climate Protection software \\
\hline Hayward & Yes & Clean Air Climate Protection software \\
\hline Menlo Park & Yes & Clean Air Climate Protection software \\
\hline Pittsburg & Yes & Clean Air Climate Protection software \\
\hline Santa Cruz & Yes & Clean Air Climate Protection software \\
\hline
\end{tabular}

Source: Author's review of inventory documents of selected California cities

\subsubsection{Data availability and establishing a baseline year}

Five of the eight inventories surveyed used 2005 as its baseline inventory year (Berkeley, Chico,

Hayward, Menlo Park, and Pittsburg). The Davis inventory used 1990 as the baseline inventory

year. The Benicia inventory used 2000 as its baseline year but developed an interim emissions

inventory for 2005. The inventory document reviewed for Santa Cruz is that city's third community inventory, and estimates emissions for 2005. The baseline inventory year for Santa Cruz is 1996, with its second inventory completed for 2000. Santa Cruz used 1993 as a baseline year for its municipal inventory, with interim inventories completed for 1996, 2000, and 2005. See Table 2.6 for a comparison of baseline years selected by each of the eight jurisdictions. Including the interim inventories completed by Benicia and Santa Cruz for 2005, seven of the eight inventories (with the exception of Davis) completed an inventory for 2005, which is a common baseline year used by many jurisdictions throughout California. 
TABLE 2.6: Baseline year of inventory and data collected for multiple years

\begin{tabular}{|l|l|}
\hline Jurisdiction & \multicolumn{1}{|c|}{ Q5. What is baseline year of inventory? Was data collected for multiple years? } \\
\hline Benicia & 2000 (interim inventory in 2005) \\
\hline Berkeley & 2005 \\
\hline Chico & 2005 (adjacent years include 2003 through 2007, varies by sector) \\
\hline Davis & 1990 \\
\hline Hayward & 2005 \\
\hline Menlo Park & 2005 \\
\hline Pittsburg & 2005 \\
\hline Santa Cruz & $\begin{array}{l}1996 \text { for Community (inventory also completed for 2000 and 2005); 1993 for Municipal } \\
\text { (inventory also completed for 1996, 2000 and 2005) }\end{array}$ \\
\hline
\end{tabular}

Source: Author's review of inventory documents of selected California cities

The purpose for identifying a baseline year is to allow a jurisdiction to measure its progress in meeting its greenhouse gas emissions reduction goals in later years. The baseline year was generally selected based on the availability of a complete data set for all sectors of community and municipal inventories.

Because it identified 1990 as its baseline year, the data collection and estimated methods used in the Davis inventory differ from the data collection methods used by the other inventories surveyed, due to limited data availability. For example, regarding residential and commercial/industrial sectors of the community inventory, the Davis inventory states, “The best available data on 1990 community electricity consumption is determined from the franchise tax paid to the City of Davis. Assuming the 1990 effective tax rate is 10.37 cents per $\mathrm{kWh}$, a total of $253,770,183 \mathrm{kWh}$ were consumed.” ${ }^{25}$ By comparison, the other seven inventories used annual electricity usage data (in kilowatt-hours) as opposed to franchise tax paid to the city. Section 2.3 contains a complete discussion of data sources for each sector of the eight inventories surveyed.

${ }^{25}$ City of Davis Greenhouse Gas Inventory \& Forecast Report, Christa Clark Jones, March 2008, p. 10. 


\subsubsection{Comparability of local emissions inventories}

In an effort to gauge how reasonable it is to compare the emissions inventories of communities of a similar size, the presence of unique or major facilities in or adjacent to each of the eight jurisdictions were identified. Specifically, the presence of universities or community colleges, major industrial sources, and airports were noted for each of the eight jurisdictions (see Table 2.7).

TABLE 2.7: Presence of unique or major facilities in or adjacent to jurisdiction

\begin{tabular}{|l|l|}
\hline Jurisdiction & \multicolumn{1}{|c|}{ Q33. Presence of unique facilities in or adjacent to jurisdiction? } \\
\hline Benicia & Valero refinery, Port of Benicia \\
\hline Berkeley & UC Berkeley, Lawrence Berkeley National Laboratory \\
\hline Chico & CSU Chico, Chico Municipal Airport \\
\hline Davis & UC Davis (campus not within city limits, but adjacent to downtown) \\
\hline Hayward & CSU East Bay (formerly CSU Hayward), Hayward Executive Airport, Chabot College \\
\hline Menlo Park & Menlo College (Stanford University is adjacent to city limits, located in Palo Alto) \\
\hline Pittsburg & Three natural gas power plants, petroleum coke plant, Los Medanos College \\
\hline Santa Cruz & UC Santa Cruz (campus not within city limits, but within a few miles of downtown) \\
\hline
\end{tabular}

Source: Author's review of inventory documents of selected California cities

Five of the eight communities (Berkeley, Chico, Davis, Hayward and Santa Cruz) are home to a state university campus ${ }^{26}$. The five inventory documents differ in how emissions generated by college campuses are considered. In its inventory, Chico specifically includes emissions generated by the CSU Chico campus in the commercial sector, where emissions generated by the campus account for 26 percent of emissions generated by the commercial sector ${ }^{27}$. In its inventory, Berkeley mentions the presence of UC Berkeley, but does not include emissions generated at the campus or at the Lawrence Berkeley National Laboratory ${ }^{28}$. Although the CSU East Bay (formerly CSU Hayward)

\footnotetext{
${ }^{26}$ The campuses of CSU Chico, CSU East Bay and UC Berkeley are located within the city limits of the respective jurisdiction. The campuses of UC Davis and UC Santa Cruz are located adjacent to, but outside, the city limits of the respective jurisdiction.

${ }^{27}$ City of Chico Community and Municipal Greenhouse Gas \& Criteria Air Pollutant Emissions Inventory, Daniel Salazar, April 2008, p. 17.

${ }^{28}$ The document states, "When calculating Berkeley's emissions inventory, all energy consumed within the city limits was included, with the exception of fuel used on freeways, electricity and natural gas consumption in County-owned
} 
campus is located within Hayward city limits, the inventory document does not mention the presence of the university and its associated emissions. As the campuses of UC Davis and UC Santa Cruz are outside the city limits of each respective jurisdiction, it is not surprising that universityrelated emissions are not included in each respective inventory. However, there is no discussion of the emissions generated on each university campus, or the emissions generated by the university population in the greater community ${ }^{29}$. The campus of California Polytechnic State University, San Luis Obispo is located adjacent to, but outside, the city limits of San Luis Obispo, creating a similar situation to Davis and Santa Cruz as it relates to jurisdictional boundaries.

Hayward, Menlo Park and Pittsburg are each home to a community college campus. No specific reference is made in these two inventories regarding the inclusion of the emissions generated by these college campuses. There is no college campus located in Benicia.

The cities of Benicia and Pittsburg each have a significant industrial presence in their respective communities. Benicia ${ }^{30}$ is the location of the only Valero oil refinery in Northern California. Other industrial sources are located in the vicinity of the Port of Benicia. Pittsburg ${ }^{31}$ is home to three natural gas power plants and a petroleum coke plant, among other industrial sources.

facilities, UCB [Berkeley] and LBL [Lawrence Berkeley National Laboratory] and natural gas used for electricity generation at DPS [Delta Power Services]." City of Berkeley Baseline Greenhouse Gas Emissions Inventory Report, ICLEI and Neal DeSnoo, April 2007, p. 7.

${ }^{29}$ UC Davis is only noted as being served by Unitrans, the transit system that serves the Davis community and campus (City of Davis Greenhouse Gas Inventory \& Forecast Report, Christa Clark Jones (city staff), March 2008, p. 11). UC Santa Cruz is only noted as being a partner in the creation of the Climate Action Compact between the City, County and university (City of Santa Cruz Greenhouse Gas Emissions Inventory 2005 Municipal and Community Emissions, Ross Clark and Charlie Lewis, August 2008, p. 7).

${ }^{30}$ Benicia is located on the north shore of the Carquinez Strait, which is the body of water connecting San Pablo Bay to the inland Suisun Bay.

${ }^{31}$ Pittsburg is located about eight miles east of Benicia on the south shore of the Suisun Bay. 
Two of the eight jurisdictions have an airport located within city limits. Hayward Executive Airport does not offer commercial airline service, but does offer charter airline service. One commercial airline provides service to Chico Municipal Airport and provides four departures per day $^{32}$. The airport also accommodates general aviation and is a primary base for aerial firefighting missions in Northern California. Neither inventory document mentions the presence of the airport in their respective jurisdiction or the emissions generated by the airport. No airports are present in the other six communities. The San Luis Obispo County Regional Airport is a commercial airport operated by the County and is located adjacent to, but outside, the city limits of San Luis Obispo. Of the eight inventories surveyed, no jurisdiction has this similar situation.

The identification of differences between the eight communities highlights the challenge in directly comparing emissions inventories between cities - even cities which fall within the same population range.

\subsection{Community inventory sectors}

The following section provides a detailed analysis of the sectors included in the community emissions inventory. The sectors are residential, commercial, industrial, transportation and waste. As five of eight inventories combined the emissions figures for the commercial and industrial sectors for various reasons, those two sectors have been combined in this section. For each sector, a summary table identifies the following: data sources used; energy, fuel, or waste data collected; and the emissions calculation methodology.

${ }^{32}$ http://www.chico.ca.us/airport/commercial airline schedule.asp 


\subsubsection{Residential sector}

The data collection methodology used for the residential sector is relatively consistent for the eight inventories reviewed. While all eight inventories collect energy data for electricity and natural gas, two of the eight inventories do not determine electricity and natural gas usage based directly on kilowatt-hours of electricity and therms of natural gas. Table 2.8 provides a summary of the data sources and the methodology used to calculate emissions attributable to the residential sector for the eight inventories reviewed.

The Davis inventory estimated electricity usage in 1990 based on the franchise tax paid to the city by the utility, while natural gas usage is based on national per capita natural gas consumption figures from the U.S. Department of Energy. The Pittsburg inventory derived residential natural gas usage from the statewide greenhouse gas inventory. The Menlo Park inventory included electricity usage figures for direct access customers. 
TABLE 2.8: Residential sector - data source and emissions calculation methodology

\begin{tabular}{|c|c|c|c|}
\hline Jurisdiction & Data source $(s)$ & $\begin{array}{l}\text { Energy data } \\
\text { collected }\end{array}$ & $\begin{array}{l}\text { Energy usage and emissions calculation } \\
\text { methodology }\end{array}$ \\
\hline Benicia & $\begin{array}{l}\text { Pacific Gas \& } \\
\text { Electric }\end{array}$ & $\begin{array}{l}\text { Electricity and } \\
\text { natural gas }\end{array}$ & $\begin{array}{l}\text { - } \quad \text { Total kWh of electricity consumed } \\
\text { - } \quad \text { Total therms of natural gas consumed } \\
\text { - Used } 2003 \text { data for } 2000 \text { inventory due to } 0 \% \\
\text { population growth; used } 2005 \text { data for } 2005 \\
\text { inventory }\end{array}$ \\
\hline Berkeley & $\begin{array}{l}\text { Pacific Gas \& } \\
\text { Electric }\end{array}$ & $\begin{array}{l}\text { Electricity and } \\
\text { natural gas }\end{array}$ & $\begin{array}{l}\text { - Total kWh of electricity consumed } \\
\text { - } \quad \text { Total therms of natural gas consumed }\end{array}$ \\
\hline Chico & $\begin{array}{l}\text { Pacific Gas \& } \\
\text { Electric }\end{array}$ & $\begin{array}{l}\text { Electricity and } \\
\text { natural gas }\end{array}$ & $\begin{array}{l}\text { - } \quad \text { Total kWh of electricity consumed } \\
\text { - } \quad \text { Total therms of natural gas consumed } \\
\text { - } \quad \text { Data collected for } 2003 \text { through } 2006\end{array}$ \\
\hline \multirow{2}{*}{ Davis } & $\begin{array}{l}\text { Franchise tax paid } \\
\text { to city in } 1990 \text { by } \\
\text { Pacific Gas \& } \\
\text { Electric }\end{array}$ & Electricity & 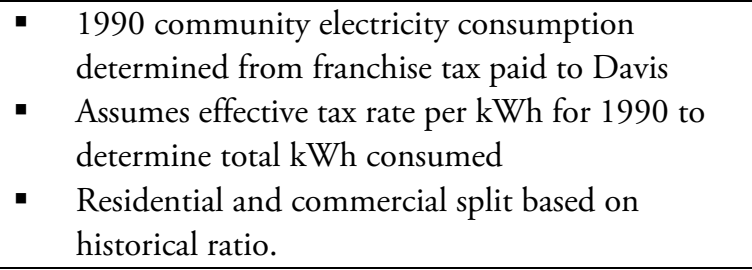 \\
\hline & $\begin{array}{l}\text { California energy } \\
\text { statistics, U.S. } \\
\text { Department of } \\
\text { Energy }\end{array}$ & Natural gas & $\begin{array}{l}\text { - California energy statistics from } 1990 \text { are used to } \\
\text { determine the best estimate of natural gas } \\
\text { consumption } \\
\text { U.S. Department of Energy-estimated per capita } \\
\text { natural gas consumption is multiplied by } 1990 \\
\text { Davis population }\end{array}$ \\
\hline Hayward & $\begin{array}{l}\text { Pacific Gas \& } \\
\text { Electric }\end{array}$ & $\begin{array}{l}\text { Electricity and } \\
\text { natural gas }\end{array}$ & $\begin{array}{l}\text { - Total kWh of electricity consumed } \\
\text { - } \quad \text { Total therms of natural gas consumed }\end{array}$ \\
\hline Menlo Park & $\begin{array}{l}\text { Pacific Gas \& } \\
\text { Electric, California } \\
\text { Public Utilities } \\
\text { Commission }\end{array}$ & $\begin{array}{l}\text { Electricity and } \\
\text { natural gas }\end{array}$ & $\begin{array}{l}\text { - Total kWh of electricity consumed } \\
\text { - } \quad \text { Total therms of natural gas consumed } \\
\text { - } \quad \text { Direct access customers (those that purchase } \\
\text { electricity directly from power generation } \\
\text { facilities) calculated separately }\end{array}$ \\
\hline Pittsburg & $\begin{array}{l}\text { Pacific Gas \& } \\
\text { Electric } \\
\text { (electricity); } \\
\text { California Energy } \\
\text { Commission, } \\
\text { Energy } \\
\text { Information } \\
\text { Administration } \\
\text { (natural gas) }\end{array}$ & $\begin{array}{l}\text { Electricity and } \\
\text { natural gas }\end{array}$ & $\begin{array}{l}\text { - } \quad \text { Total kWh of electricity consumed } \\
\text { Natural gas usage data derived from California } \\
\text { Energy Commission's Inventory of California } \\
\text { Greenhouse Gas Emissions and Sinks: 1990-1999; } \\
\text { and Energy Information Administration's } \\
\text { Emissions of Greenhouse Gases in United States } \\
2000 \\
\mathrm{CH}_{4} \text { and } \mathrm{N}_{2} \mathrm{O} \text { emission factors derived from U.S. } \\
\text { Environmental Protection Agency and } \\
\text { Intergovernmental Panel on Climate Change }\end{array}$ \\
\hline Santa Cruz & $\begin{array}{l}\text { Pacific Gas \& } \\
\text { Electric } \\
\text { (electricity) }\end{array}$ & $\begin{array}{l}\text { Electricity and } \\
\text { natural gas }\end{array}$ & $\begin{array}{l}\text { - } \quad \text { Total kWh of electricity consumed } \\
\text { - Methodology for determining natural gas usage } \\
\text { not stated }\end{array}$ \\
\hline
\end{tabular}

Source: Author's review of inventory documents of selected California cities 


\subsubsection{Commercial and Industrial sectors}

The data collection methodologies used for the commercial and industrial sectors have few commonalities between the eight inventories reviewed. Three of the eight inventories calculate emissions based on kilowatt-hours of electricity used and therms of natural gas consumed. Table 2.9 provides a summary of the data sources and the methodology used to calculate emissions attributable to the commercial and industrial sectors for the eight inventories reviewed.

The Davis inventory estimated electricity usage in 1990 based on the franchise tax paid to the city by the utility, while using a more complicated method to estimate natural gas usage in 1990 . The Davis inventory utilized national figures for energy intensity of buildings by building type and applied those to the building activities in 1990 to estimate natural gas usage for the commercial sector. The Benicia inventory estimated natural gas use based on estimated commercial share of the combined residential and commercial natural gas usage. The Pittsburg inventory included point source emissions data for seven industrial sources as part of the industrial sector.

Two of the eight inventories collected data for multiple years as part of the commercial sector. Five of the eight inventories combined commercial and industrial figures; some due to confidentiality rules and some due to limited industrial presence within the community. 


\section{TABLE 2.9: Commercial and Industrial sectors - data source and emissions calculation methodology}

\begin{tabular}{|c|c|c|c|}
\hline Jurisdiction & Data source $(s)$ & $\begin{array}{l}\text { Energy data } \\
\text { collected }\end{array}$ & $\begin{array}{c}\text { Energy usage and emissions calculation } \\
\text { methodology }\end{array}$ \\
\hline \multirow[t]{2}{*}{ Benicia } & $\begin{array}{l}\text { Pacific Gas \& } \\
\text { Electric, U.S. Census } \\
\text { Business Patterns }\end{array}$ & Electricity & $\begin{array}{l}\text { - To estimate electricity, used average ratio of therms to } \\
\text { kWh for } 2003,2004 \text { and } 2005 \\
\text { Multiplied } 2003 \text { data by } 93 \% \text { to account for fewer } \\
\text { commercial and industrial establishments in } 2000 \text { (for } \\
2000 \text { inventory) }\end{array}$ \\
\hline & $\begin{array}{l}\text { PG\&E, U.S. Census } \\
\text { Business Patterns, } \\
\text { ABAG }\end{array}$ & Natural gas & $\begin{array}{l}\text { - Natural gas use is estimated commercial share } \\
\text { (provided by ABAG) reported for } 2000 \text { of the } \\
\text { combined residential and commercial natural gas use }\end{array}$ \\
\hline Berkeley & $\begin{array}{l}\text { Pacific Gas \& } \\
\text { Electric }\end{array}$ & $\begin{array}{l}\text { Electricity and } \\
\text { natural gas }\end{array}$ & $\begin{array}{l}\text { - Electricity and natural gas consumption in County- } \\
\text { owned facilities, UC Berkeley, Lawrence Berkeley } \\
\text { National Laboratory were subtracted from the } \\
\text { Commercial data }\end{array}$ \\
\hline Chico & $\begin{array}{l}\text { Pacific Gas \& } \\
\text { Electric }\end{array}$ & $\begin{array}{l}\text { Electricity and } \\
\text { natural gas }\end{array}$ & $\begin{array}{ll}\text { - } & \text { Total } \mathrm{kWh} \text { of electricity consumed } \\
\text { - } & \text { Total therms of natural gas consumed } \\
\text { - } & \text { Data collected for } 2003 \text { through } 2006\end{array}$ \\
\hline \multirow{2}{*}{ Davis } & $\begin{array}{l}\text { Franchise tax paid to } \\
\text { city in } 1990 \text { by } \\
\text { Pacific Gas \& } \\
\text { Electric }\end{array}$ & Electricity & $\begin{array}{l}1990 \text { community electricity consumption determined } \\
\text { from franchise tax paid to Davis } \\
\text { - Assumes effective tax rate per kWh for } 1990 \text { to } \\
\text { determine total } \mathrm{kWh} \text { consumed } \\
\text { - Residential-commercial split based on historic ratio }\end{array}$ \\
\hline & $\begin{array}{l}\text { U.S. Energy } \\
\text { Information } \\
\text { Administration, city } \\
\text { finance department }\end{array}$ & Natural gas & $\begin{array}{l}\text { - } 1990 \text { building activities compared with associated } \\
\text { energy intensity (amount of natural gas used per square } \\
\text { foot in a building) } \\
1989 \text { average obtained from U.S. Energy Information } \\
\text { - Administration }\end{array}$ \\
\hline Hayward & $\begin{array}{l}\text { Pacific Gas \& } \\
\text { Electric }\end{array}$ & $\begin{array}{l}\text { Electricity and } \\
\text { natural gas }\end{array}$ & $\begin{array}{l}\text { - Total kWh of electricity consumed } \\
\text { - Total therms of natural gas consumed } \\
\text { - Commercial sector includes energy consumed by city } \\
\text { buildings, operations and facilities as well as district } \\
\text { facilities like the East Bay Municipal Utility District, } \\
\text { Bay Area Rapid Transit, and school districts } \\
\text { - Industrial data reported within commercial sector due } \\
\text { to California Public Utilities Commission } \\
\text { confidentiality rules }\end{array}$ \\
\hline Menlo Park & $\begin{array}{l}\text { Pacific Gas \& } \\
\text { Electric, California } \\
\text { Public Utilities } \\
\text { Commission }\end{array}$ & $\begin{array}{l}\text { Electricity and } \\
\text { natural gas }\end{array}$ & $\begin{array}{l}\text { - Total kWh of electricity consumed } \\
\text { - Total therms of natural gas consumed } \\
\text { - Direct access customers (those that purchase electricity } \\
\text { directly from power generation facilities) calculated } \\
\text { separately }\end{array}$ \\
\hline Pittsburg & $\begin{array}{l}\text { Bay Area AQMD } \\
\text { (point source } \\
\text { emissions); } \\
\text { ICLEI } \\
\text { (direct access } \\
\text { electricity) }\end{array}$ & $\begin{array}{l}\text { Point source } \\
\text { emissions, direct } \\
\text { access electricity } \\
\text { for non- } \\
\text { residential } \\
\text { customers }\end{array}$ & $\begin{array}{l}\text { - Point source emissions data for seven industrial sources } \\
\text { was provided by Bay Area AQMD } \\
\text { Direct access electricity emissions of non-residential } \\
\text { customers estimated based on share of direct access } \\
\text { customers as compared to all electricity customers in } \\
\text { county }\end{array}$ \\
\hline Santa Cruz & $\begin{array}{l}\text { PG\&E } \\
\text { (electricity) }\end{array}$ & $\begin{array}{l}\text { Electricity and } \\
\text { natural gas }\end{array}$ & $\begin{array}{l}\text { - Methodology for determining emissions from } \\
\text { Commercial/Industrial sector not stated }\end{array}$ \\
\hline
\end{tabular}

Source: Author's review of inventory documents of selected California cities 


\subsubsection{Transportation sector}

Based on the review of eight community-wide emissions inventories, the emissions from the transportation sector attributed to a community is typically calculated by using an identified figure for daily vehicle-miles of travel (DVMT) ${ }^{33}$ for the community; that figure is then multiplied by the number of days in a year; then the vehicle distribution data (typically county-wide figures) is then applied to the annual vehicle-miles of travel. However, no consistent methodology to calculate vehicle-miles of travel for a community exists for the eight inventories reviewed. Table 2.10 provides a summary of the data sources used, data collected, and methodology used to determine the annual VMT for a given community.

In order to determine community-wide DVMT, four different data sources were used for the eight inventories. Three of the eight inventories used the Caltrans' California Public Road Data publication $^{34}$; three of the eight inventories received an estimate of city-wide weekday vehicle-miles of travel (VMT) data from the metropolitan planning organization or regional transportation planning agency; one inventory referenced the federal Highway Statistics publication $^{35}$; and the other inventory estimated city-wide VMT from Caltrans' Motor Vehicle Stock Travel, and Fuel Forecast publication $^{36}$.

\footnotetext{
${ }^{33}$ DVMT is daily vehicle-miles of travel for roadways in a geographic area, such as all city streets in a given community. ${ }^{34}$ This annual publication is a set of statistical tabulations maintained on an annual basis as part of the federal Highway Performance Monitoring System.

35 This annual publication is updated using the federal Highway Performance Monitoring System and is maintained by the Office of Highway Policy Information of the Federal Highway Administration.

36 This annual publication updates, estimates, and forecasts the annual statewide and countywide number of vehicles, vehicle-miles of travel, vehicle fuel consumption, and vehicle fuel economy. It is prepared by the Statewide Modeling Branch of the Caltrans' Division of Transportation System Information.
} 
TABLE 2.10: Transportation sector - data source and emissions calculation methodology

\begin{tabular}{|c|c|c|}
\hline Jurisdiction & Data source $(s)$ & Vehicle miles of travel calculation methodology \\
\hline Benicia & $\begin{array}{l}\text { California Public } \\
\text { Road Data } \\
\text { (DVMT); } \\
\text { MTC } \\
\text { (vehicle } \\
\text { distribution data) }\end{array}$ & $\begin{array}{l}\text { - City streets: DVMT on all city streets multiplied by } 330 \text { days (to } \\
\text { account for lower traffic on weekends); applied vehicle distribution } \\
\text { - Highways: Percentage of Solano County highway miles located in } \\
\text { Benicia multiplied by DVMT for Solano County; multiplied by } \\
365 \text { days; applied vehicle distribution } \\
\text { - State Parks roads: DVMT multiplied by } 365 \text { days; applied vehicle } \\
\text { distribution } \\
\text { - Port of Benicia: Mileage for movement of imported vehicles around } \\
\text { facility }\end{array}$ \\
\hline Berkeley & $\begin{array}{l}\text { MTC } \\
\text { (citywide weekday } \\
\text { VMT data); } \\
\text { Bay Area AQMD } \\
\text { (Alameda } \\
\text { County's VMT } \\
\text { distribution by } \\
\text { fuel and vehicle } \\
\text { type); } \\
\text { ABAG } \\
\text { (population } \\
\text { growth rate) }\end{array}$ & $\begin{array}{l}\text { - City streets: Applied annual population growth rate to } 2004 \text { weekday } \\
\text { VMT data to determine } 2005 \text { weekday VMT data; VMT including } \\
\text { weekends is calculated with the weekdays/weekends VMT ratio of } \\
\text { 1.1489; formula used to calculate Annual VMT as follows: } \\
\text { [Annual VMT = DVMT x (\# of weekdays in base year) + } \\
\text { DVMT/1.1489 x (365 - \# of weekdays in base year)] } \\
\text { - Highways: Interstate VMT not included in analysis }\end{array}$ \\
\hline Chico & $\begin{array}{l}\text { California Public } \\
\text { Road Data } \\
\text { (DVMT, 2004- } \\
\text { 2006) }\end{array}$ & $\begin{array}{l}\text { - DVMT for "Greater Chico Area"; data available for } 2004 \text { through } \\
\text { 2006; no multiplier is stated in report for the number of days in a } \\
\text { year }\end{array}$ \\
\hline Davis & $\begin{array}{l}\text { Federal Highway } \\
\text { Administration } \\
\text { (DVMT, 1994- } \\
\text { 2005); } \\
\text { Solano-Yolo } \\
\text { AQMD } \\
\text { (vehicle } \\
\text { distribution data) }\end{array}$ & $\begin{array}{l}\text { - Average DVMT data is available by type of roadway in Davis; the } \\
\text { average annual percentage change between } 1994 \text { and } 2005 \text { was used } \\
\text { to estimate average DVMT in 1990; DVMT multiplied by } 330 \\
\text { days; applied vehicle distribution }\end{array}$ \\
\hline Hayward & $\begin{array}{l}\text { MTC } \\
\text { (citywide weekday } \\
\text { VMT data); } \\
\text { Bay Area AQMD } \\
\text { (vehicle } \\
\text { distribution data) }\end{array}$ & $\begin{array}{l}\text { - DVMT data on all city streets and highways; DVMT multiplied by } \\
365 \text { days; applied vehicle distribution }\end{array}$ \\
\hline Menlo Park & $\begin{array}{l}\text { California Public } \\
\text { Road Data } \\
\text { (DVMT); } \\
\text { MTC } \\
\text { (highway VMT by } \\
\text { segment); } \\
\text { Caltrain (ridership } \\
\text { data) }\end{array}$ & $\begin{array}{l}\text { - City streets: VMT data on all city streets; no multiplier is stated in report for } \\
\text { the number of days in a year } \\
\text { - Highways: VMT data disaggregated by highway segment for six state } \\
\text { highways; VMT from section of highway segment running on Menlo Park- } \\
\text { Atherton border split between the two cities } \\
\text { - Caltrain: Assigned emissions from estimated fuel usage by Caltrain serving } \\
\text { Menlo Park residents; used ridership figures from Menlo Park station, } \\
\text { roundtrip distance to north and south termini, and fuel efficiency of } \\
\text { Caltrain vehicles }\end{array}$ \\
\hline
\end{tabular}


TABLE 2.10: Transportation sector - data source and emissions calculation methodology (cont'd.)

\begin{tabular}{|c|c|c|}
\hline Jurisdiction & Data source $(s)$ & Vehicle miles of travel calculation methodology \\
\hline Pittsburg & $\begin{array}{l}\text { Contra Costa } \\
\text { Transportation } \\
\text { Authority } \\
\text { (average weekday } \\
\text { VMT data); } \\
\text { Bay Area AQMD } \\
\text { (vehicle } \\
\text { distribution data); } \\
\text { USS-POSCO and } \\
\text { Koch Carbon, } \\
\text { California Air } \\
\text { Resources Board } \\
\text { (marine } \\
\text { transportation) }\end{array}$ & $\begin{array}{l}\text { Community inventory reports transportation in two ways: regional } \\
\text { (including highways and marine transportation) and local (city streets). } \\
\text { - Highway [Regional]: Average weekday DVMT for highways within } \\
\text { city multiplied by } 365 \text { days; applied vehicle distribution } \\
\text { - Marine [Regional]: County average berthing and hotelling emissions } \\
\text { per vessel call were estimated based on Carquinez and Richmond } \\
\text { port data; marine emissions data for Bay Area and Contra Costa } \\
\text { County used to count transit emissions } \\
\text { - City streets [Local]: Average weekday DVMT for city streets } \\
\text { multiplied by } 365 \text { days; applied vehicle distribution }\end{array}$ \\
\hline Santa Cruz & $\begin{array}{l}2000 \text { and } 2005 \\
\text { MVSTAFF report } \\
\text { (Caltrans) }\end{array}$ & $\begin{array}{l}\text { - } 2005 \text { VMT calculated based on a 2.4\% increase in VMT between } \\
2000 \text { and } 2005 \text { within Santa Cruz County } \\
\text { - Values were extrapolated from } 2000 \text { municipal inventory because city- } \\
\text { specific VMT estimates were not available }\end{array}$ \\
\hline
\end{tabular}

Source: Author's review of inventory documents of selected California cities

Four of the eight inventories received the vehicle distribution data from the air quality management district; two of the eight inventories received the vehicle distribution data from the metropolitan planning organization or regional transportation planning agencies, while the other two inventories did not make specific reference to vehicle distribution data. Vehicle distribution data typically was available at the county-level as opposed to the community-level.

No consistent method was used to calculate annual VMT from DVMT among the eight inventories. Two of the eight jurisdictions used 365 days as the multiplier to determine annual VMT. One of the eight jurisdictions used 330 days as the multiplier to determine annual VMT. The Benicia inventory used 365 days as the multiplier for highways and state park roads, but used 330 days as the multiplier for city streets. The Santa Cruz inventory extrapolated the annual VMT for 2005 from annual figures from Caltrans' 2000 MVSTAFF report of countywide VMT figures. The 
Berkeley inventory used a weekday/weekend VMT ratio to assist in calculating annual VMT. The two other inventories did not explain how annual VMT was determined from a DVMT figure.

Vehicle-miles of travel on interstates or highways within the jurisdiction are consistently included in the total VMT figure for a given community. Seven of the eight inventories include interstate or state highway VMT in the inventory. The Pittsburg inventory presents the transportation sector in two different ways - regional and local transportation. In the regional analysis, the inventory includes highway VMT while the local analysis excludes highway VMT.

Some of the inventories include transportation-related emissions beyond those attributable to VMT on highways and city streets. The Menlo Park inventory estimates emissions from Caltrain vehicles that may be attributable to passengers boarding and alighting at the Menlo Park station. The Pittsburg inventory estimates emissions from marine transportation, including hotelling, maneuvering, and transit of vessels. The Benicia inventory includes the VMT of imported vehicles on the port property and VMT in the state park.

\subsubsection{Solid Waste sector}

The inventories reviewed reveal that waste emissions are typically calculated based on waste tonnage generated by a community, the waste stream composition is identified, and a methane recovery factor is applied in most cases. Table 2.11 provides a summary of the data sources used, the data collected, and the methodology used to calculate waste emissions for a given community.

Seven of the eight inventories reviewed state the data source for the waste tonnage generated by the community. The data source for waste tonnage information varied among the inventories reviewed. The data sources included the waste management authority, the waste disposal company, 
TABLE 2.11: Solid waste sector - data source and emissions calculation methodology

\begin{tabular}{|c|c|c|}
\hline Jurisdiction & Data source(s) & Waste emissions calculation methodology \\
\hline Benicia & $\begin{array}{l}\text { Allied Waste Services } \\
\text { (waste tonnage); } \\
\text { California Integrated Waste } \\
\text { Management Board } \\
\text { (residential waste stream) }\end{array}$ & $\begin{array}{l}\text { - Data included: Cardboard and mixed paper recycled by } \\
\text { Benicia Unified School District; sludge tonnage from } \\
\text { wastewater and water treatment plant; residential } \\
\text { greenwaste; commercial waste } \\
\text { - Residential waste stream composition based on CIWMB's } \\
\text { Solid Waste Characterization Database }\end{array}$ \\
\hline Berkeley & $\begin{array}{l}\text { Alameda County Waste } \\
\text { Management Authority } \\
\text { (Landfill data and waste } \\
\text { characterization study); } \\
\text { EPA Landfill Methane } \\
\text { Outreach Program } \\
\text { (methane recovery factor) }\end{array}$ & $\begin{array}{l}\text { - Data included: Waste tonnage for seven landfills receiving } \\
\text { waste from community; used weighted average methane } \\
\text { recovery factor for all landfills } \\
\text { - Waste stream composition based on Alameda County Waste } \\
\text { Characterization Study }\end{array}$ \\
\hline Chico & $\begin{array}{l}\text { City of Chico staff; } \\
\text { Butte County Solid } \\
\text { Waste Manager } \\
\text { (waste tonnage); } \\
\text { CIWMB } \\
\text { (waste stream composition) }\end{array}$ & $\begin{array}{l}\text { - Data included: Waste tonnage data for two primary landfills } \\
\text { - Waste stream composition based on CACP software's default } \\
\text { distribution }\end{array}$ \\
\hline Davis & $\begin{array}{l}\text { City of Davis staff } \\
\text { (waste tonnage and waste } \\
\text { stream composition) }\end{array}$ & $\begin{array}{l}\text { - Data included: } 1990 \text { waste tonnage data for primary landfill } \\
\text { - Waste stream composition based on waste characterization } \\
\text { study provided by city staff }\end{array}$ \\
\hline Hayward & $\begin{array}{l}\text { Alameda County Waste } \\
\text { Management Authority } \\
\text { (Landfill data and waste } \\
\text { characterization study); } \\
\text { EPA Landfill Methane } \\
\text { Outreach Program } \\
\text { (methane recovery factor); } \\
\text { ABAG } \\
\text { (projections report) }\end{array}$ & $\begin{array}{l}\text { - Data included: Waste tonnage data for two primary landfills; } \\
\text { used weighted average methane recovery factor for all } \\
\text { landfills } \\
\text { - Waste stream composition based on } 2000 \text { Alameda County } \\
\text { Waste Characterization Study; growth rate based on socio- } \\
\text { economic projections report published by ABAG }\end{array}$ \\
\hline Menlo Park & $\begin{array}{l}\text { CIWMB } \\
\text { (waste tonnage and waste } \\
\text { stream composition); } \\
\text { Bay Area AQMD } \\
\text { (waste tonnage in Marsh } \\
\text { Road Landfill) }\end{array}$ & $\begin{array}{l}\text { - Data included: Waste tonnage data for primary landfill } \\
\text { (located outside city); waste tonnage in the closed Marsh } \\
\text { Road Landfill (within city) } \\
\text { - Emissions from the Marsh Road Landfill calculated using the } \\
\text { Waste-In-Place method, which is based on the amount of } \\
\text { waste in the landfill less the amount of gas recovered } \\
\text { - Waste stream composition based on CIWMB's Solid Waste } \\
\text { Characterization Study }\end{array}$ \\
\hline Pittsburg & $\begin{array}{l}\text { Pittsburg Disposal Service } \\
\text { (waste tonnage and disposal } \\
\text { methods); } \\
\text { CIWMB } \\
\text { (waste stream composition); } \\
\text { Contra Costa County Climate } \\
\text { Planner } \\
\text { (methane recovery factor) } \\
\end{array}$ & $\begin{array}{l}\text { - Data included: Total solid waste tonnage, total alternate } \\
\text { daily cover, compost tonnage, recycled tonnage, special } \\
\text { waste tonnage, biomass and controlled incineration } \\
\text { tonnage } \\
\text { - Waste stream composition based on CIWMB's Waste } \\
\text { Characterization Study } \\
\text { - Methane recovery factor based on IPCC recommendation }\end{array}$ \\
\hline Santa Cruz & Data sources not stated & $\begin{array}{l}\text { - Methane recovery occurs at the city landfill and wastewater } \\
\text { treatment plant }\end{array}$ \\
\hline
\end{tabular}

Source: Author's review of inventory documents of selected California cities 
city staff, the air quality management district, and California Integrated Waste Management Board (CIWMB).

Seven of the eight inventories reviewed state the data source for the waste stream composition. Four of the eight inventories use the CIWMB's Waste Characterization Study as the data source for the community's waste stream composition. Other data sources include the waste management authority or city staff.

\subsection{Municipal inventory sectors}

The following section provides a detailed analysis of the sectors included in the municipal inventory. The sectors included by most of the inventories reviewed are buildings and facilities, vehicle fleet, employee commute, streetlights and traffic signals, water and sewer, and waste. For each sector, a summary table identifies the following: data sources used; energy, fuel, or waste data collected; and the emissions calculation methodology.

Although no standard protocol exists at this time for the community inventory, the Local Government Operations Protocol (Protocol) was published in 2008 for use as an emissions reporting protocol to quantify emissions generated by the operations of a local government ${ }^{37}$. Due to the publication date of the Protocol, only the Pittsburg and Santa Cruz inventories reference the document. Only the Pittsburg inventory organizes and quantifies emissions in terms of emission scopes $^{38}$.

${ }^{37}$ Section 3.5 includes a further discussion of the Local Government Operations Protocol.

${ }^{38}$ The concept of emissions scopes are discussed in section 3.7. 
Many jurisdictions recognize that one of the benefits of reporting emissions from municipal operations is to be a leader by example to the community at large. The municipal inventory provides an opportunity for the government to recognize, publicize, and promote their environmental stewardship. However, emissions generated by municipal operations generally represent a small percentage of total community emissions. Table 2.12 shows that municipal emissions as a percentage of community emissions for the eight inventories reviewed range from 0.1 percent (Pittsburg) to 3.7 percent (Santa Cruz).

TABLE 2.12: Municipal emissions as a percentage of community emissions

\begin{tabular}{|c|c|c|c|}
\hline Jurisdiction & $\begin{array}{l}\text { Municipal emissions } \\
\text { in inventory year }\end{array}$ & $\begin{array}{l}\text { Community emissions } \\
\text { in inventory year }\end{array}$ & $\begin{array}{l}\text { Municipal emissions } \\
\text { as a percentage of } \\
\text { Community emissions }\end{array}$ \\
\hline Benicia & 7,423 & $4,247,875$ & $0.2 \%$ \\
\hline Berkeley & 6,477 & 634,797 & $1.0 \%$ \\
\hline Chico & 6,678 & 610,951 & $1.1 \%$ \\
\hline Davis & 6,804 & 225,200 & $3.0 \%$ \\
\hline Hayward & 10,562 & $1,279,438$ & $0.8 \%$ \\
\hline Menlo Park & 2,183 & 487,888 & $0.4 \%$ \\
\hline Pittsburg & 5,508 & $4,394,214$ & $0.1 \%$ \\
\hline Santa Cruz & 12,017 & 327,635 & $3.7 \%$ \\
\hline
\end{tabular}

Source: Author's review of inventory documents of selected California cities

Table 2.13 provides a summary of the sectors that are included in municipal inventories included in the review. All of the inventories reviewed include a quantification of emissions from the following sectors: buildings and facilities, vehicle fleet, streetlights and traffic signals, and municipal solid waste. Most of the inventories include the water and sewer sector in the inventory report, while only four of eight inventories quantify emissions for the employee commute sector. 
TABLE 2.13: Sectors included in municipal inventory

\begin{tabular}{|c|c|c|c|c|c|c|c|}
\hline Jurisdiction & $\begin{array}{c}\text { Buildings \& } \\
\text { Facilities }\end{array}$ & $\begin{array}{c}\text { Vehicle } \\
\text { Fleet }\end{array}$ & $\begin{array}{l}\text { Employee } \\
\text { Commute }\end{array}$ & $\begin{array}{c}\text { Streetlights } \\
\text { \& Traffic } \\
\text { Signals }\end{array}$ & $\begin{array}{c}\text { Water \& } \\
\text { Sewer }\end{array}$ & Waste & Other \\
\hline Benicia & $\mathrm{X}$ & $\mathrm{X}$ & $\mathrm{X}$ & $\mathrm{X}$ & $\mathrm{X}$ & $\mathrm{X}$ & misc. \\
\hline Berkeley & $\mathrm{X}$ & $\mathrm{X}$ & & & & & \\
\hline Chico & $\mathrm{X}$ & $\mathrm{X}$ & $\mathrm{X}$ & $\mathrm{X}$ & $\mathrm{X}$ & $\mathrm{X}$ & \\
\hline Davis & $\mathrm{X}$ & $\mathrm{X}$ & $\mathrm{X}$ & $\mathrm{X}$ & $\mathrm{X}$ & $\mathrm{X}$ & \\
\hline Hayward & $\mathrm{X}$ & $\mathrm{X}$ & & $\mathrm{X}$ & $\mathrm{X}$ & $\mathrm{X}$ & \\
\hline Menlo Park & $\mathrm{X}$ & $\mathrm{X}$ & & $\mathrm{X}$ & $\mathrm{X}$ & $\mathrm{X}$ & \\
\hline Pittsburg & $\mathrm{X}$ & $\mathrm{X}$ & $\mathrm{X}$ & $\mathrm{X}$ & (not sewer) & $\mathrm{X}$ & \\
\hline Santa Cruz & $\mathrm{X}$ & $\mathrm{X}$ & & $\begin{array}{c}\text { included in } \\
\text { Building } \\
\text { sector }\end{array}$ & $\begin{array}{c}\text { Water and } \\
\text { Wastewater } \\
\text { separate }\end{array}$ & $\mathrm{X}$ & $\begin{array}{l}\text { Co-gen. } \\
\text { (nat.gas) }\end{array}$ \\
\hline
\end{tabular}

Source: Author's review of inventory documents of selected California cities

\subsubsection{Buildings and Facilities sector}

Emissions generated by the buildings and facilities sector were calculated in a similar manner for most of the eight inventories reviewed. All eight inventories collect electricity and natural gas consumption for this sector. Emissions from the buildings and facilities sector are typically calculated by determining energy usage. Energy usage and emissions figures are either disaggregated by individual building or presented in groups of buildings. Table 2.14 provides a summary of the data sources used, the data collected, and the methodology used to calculate emissions generated by the buildings and facilities sector of the eight jurisdictions.

Although most inventories calculate emissions for the buildings and facilities sector based on electricity or natural gas usage, the Benicia inventory estimates electricity usage based on the ratio of electricity use to natural gas use, based on a multi-year data set. The Davis inventory presents 1990 electricity data based on historical records. The other inventories calculate emissions based on 2005 energy usage figures. 
TABLE 2.14: Buildings and facilities sector - emissions calculation methodology and data presentation

\begin{tabular}{|c|c|c|c|}
\hline Jurisdiction & Data source $(s)$ & $\begin{array}{l}\text { Energy data } \\
\text { collected }\end{array}$ & $\begin{array}{l}\text { Summary of emissions calculation methodology } \\
\text { and data presentation }\end{array}$ \\
\hline Benicia & $\begin{array}{l}\text { Pacific Gas \& } \\
\text { Electric } \\
\text { (electricity); } \\
\text { ABAG } \\
\text { (natural gas) }\end{array}$ & $\begin{array}{l}\text { Electricity and } \\
\text { natural gas }\end{array}$ & $\begin{array}{l}\text { - Electricity usage estimated based on assumption } \\
\text { that ratio of electricity use to gas use remains } \\
\text { similar year-to-year } \\
\text { - Ratio established for } 2003,2004 \text { and } 2005 \text {; average } \\
\text { is applied to } 2000 \\
\text { - ABAG provided natural gas consumption data }\end{array}$ \\
\hline Berkeley & $\begin{array}{l}\text { Pacific Gas \& } \\
\text { Electric }\end{array}$ & $\begin{array}{l}\text { Electricity and } \\
\text { natural gas }\end{array}$ & $\begin{array}{l}\text { - Building energy usage collected by department } \\
\text { - } 2005 \mathrm{CO}_{2} \mathrm{e} \text { emissions factor is a utility-specific } \\
\text { factor, specific to PG\&E }\end{array}$ \\
\hline Chico & $\begin{array}{l}\text { No data source } \\
\text { stated }\end{array}$ & $\begin{array}{l}\text { Electricity and } \\
\text { natural gas }\end{array}$ & $\begin{array}{l}\text { - Data presented as energy usage by building } \\
\text { - Data available for } 2005,2006 \text {, and } 2007\end{array}$ \\
\hline Davis & $\begin{array}{l}\text { City staff } \\
\text { (1990 energy usage } \\
\text { for city offices); } \\
\text { PG\&E } \\
\text { (historical report on } \\
\text { municipal energy } \\
\text { usage by sector, } \\
\text { 1995-1999) }\end{array}$ & $\begin{array}{l}\text { Electricity and } \\
\text { natural gas }\end{array}$ & $\begin{array}{l}\text { - Data presented as } 1990 \text { energy usage for city } \\
\text { buildings } \\
\text { - Where data not available, estimates of total energy } \\
\text { usage and cost were made } \\
\text { - Two historical reports were available to assist in } \\
\text { determining energy usage for city buildings }\end{array}$ \\
\hline Hayward & $\begin{array}{l}\text { City staff, from } \\
\text { Pacific Gas \& } \\
\text { Electric }\end{array}$ & $\begin{array}{l}\text { Electricity and } \\
\text { natural gas }\end{array}$ & $\begin{array}{l}\text { - Data presented as energy usage for each city } \\
\text { building } \\
\text { - } 2005 \mathrm{CO}_{2} \mathrm{e} \text { emissions factor is a utility-specific } \\
\text { factor, specific to PG\&E }\end{array}$ \\
\hline Menlo Park & $\begin{array}{l}\text { Pacific Gas \& } \\
\text { Electric }\end{array}$ & $\begin{array}{l}\text { Electricity and } \\
\text { natural gas }\end{array}$ & $\begin{array}{l}\text { - Data presented as energy usage for each city } \\
\text { building }\end{array}$ \\
\hline Pittsburg & $\begin{array}{l}\text { City staff, from } \\
\text { Pacific Gas \& } \\
\text { Electric }\end{array}$ & $\begin{array}{l}\text { Electricity and } \\
\text { natural gas }\end{array}$ & - Data disaggregated by facility type \\
\hline Santa Cruz & $\begin{array}{l}\text { No data source } \\
\text { stated }\end{array}$ & $\begin{array}{l}\text { Electricity and } \\
\text { natural gas }\end{array}$ & $\begin{array}{l}\text { - Data presented as total energy usage for all city } \\
\text { buildings }\end{array}$ \\
\hline
\end{tabular}

Source: Author's review of inventory documents of selected California cities

Energy usage and emission figures are presented in three different ways in the eight inventories disaggregated by each building, disaggregated by facility type or department, or presented as a single figure for all city buildings. Four inventories disaggregated energy usage and emissions figures by each individual building, two inventories disaggregated data by facility type, while the other two inventories present a single figure for energy usage and emissions for the buildings and facilities sector. 


\subsubsection{Vehicle Fleet sector}

Based on the review of the eight inventories, limited consistency exists in the methodologies used by jurisdictions in the quantification of emissions generated by the vehicle fleet sector. All eight inventories collect fuel usage data for the respective vehicle fleets. Additionally, data is consistently disaggregated by department fleet. Table 2.15 provides a summary of the data sources used, the data collected, and the methodology used to calculate emissions generated by the municipal vehicle fleets of the eight jurisdictions.

Five of the eight inventories used fuel usage alone to calculate emissions for the respective vehicle fleets, while three inventories were able to classify vehicles by type. The Hayward inventory calculated emissions based on fuel usage data, and then applied national fuel economy standards to the vehicle fleet by type of vehicle.

Pittsburg was the only city that was able to collect a complete set of data for each vehicle: make, model, 2005 VMT, and the fuel purchases (gasoline or diesel) of each specific vehicle. This set of data allows for the most accurate calculation of emissions from a municipal vehicle fleet. 
TABLE 2.15: Vehicle fleet sector - emissions calculation methodology and data presentation

\begin{tabular}{|c|c|c|c|}
\hline Jurisdiction & Data source(s) & Data collected & $\begin{array}{c}\text { Summary of emissions calculation methodology } \\
\text { and data presentation }\end{array}$ \\
\hline Benicia & $\begin{array}{l}\text { City staff/garage } \\
\text { supervisor } \\
\text { (fuel report) }\end{array}$ & $\begin{array}{l}\text { Fuel usage for } \\
\text { entire fleet }\end{array}$ & $\begin{array}{l}\text { - Fuel usage available for 2003, which were used for } \\
2000 \text { inventory } \\
\text { - No change to fleet from } 2000 \text { to } 2003 \text {, assumes } \\
\text { constant vehicle use from } 2000 \text { to } 2003 \\
\text { - Fuel type used in software for each department } \\
\text { selected based on predominant vehicle in fleet }\end{array}$ \\
\hline Berkeley & $\begin{array}{l}\text { City staff } \\
\text { (VMT data and } \\
\text { vehicle make, } \\
\text { model, year); } \\
\text { US Dept. of } \\
\text { Energy, US EPA } \\
\text { (fuel economy for } \\
\text { hybrid vehicles) }\end{array}$ & $\begin{array}{l}\text { Fuel usage and } \\
\text { mileage of each } \\
\text { department } \\
\text { fleet }\end{array}$ & $\begin{array}{l}\text { - Data presented by department fleet } \\
\text { - Assistance with vehicle classification provided by } \\
\text { city staff }\end{array}$ \\
\hline Chico & $\begin{array}{l}\text { No data source } \\
\text { stated }\end{array}$ & $\begin{array}{l}\text { Fuel usage of } \\
\text { each } \\
\text { department } \\
\text { fleet }\end{array}$ & $\begin{array}{l}\text { - Data presented by department fleet } \\
\text { - Calculated emissions based on fuel usage } \\
\text { - Fuel usage collected, VMT data not collected } \\
\text { - Data available for FY98-99 through FY06-07 }\end{array}$ \\
\hline Davis & $\begin{array}{l}\text { City staff } \\
\text { (historical city } \\
\text { records) }\end{array}$ & $\begin{array}{l}\text { 1988-89 } \\
\text { equipment } \\
\text { rental budget, } \\
1991 \text { fleet } \\
\text { inventory, } \\
1991-2007 \text { fuel } \\
\text { consumption } \\
\text { records }\end{array}$ & $\begin{array}{l}\text { - Data presented by department fleet } \\
\text { - Includes all vehicles owned and operated by city } \\
\text { - Where data not available, estimates of total energy } \\
\text { usage and cost were made } \\
\text { - Two historical reports were available to assist in } \\
\text { determining energy usage for city buildings }\end{array}$ \\
\hline Hayward & $\begin{array}{l}\text { Equipment } \\
\text { manager } \\
\text { (fuel usage); } \\
\text { US EPA } \\
\text { (fuel economy) }\end{array}$ & Fuel usage & $\begin{array}{l}\text { - Data presented by department fleet } \\
\text { - Calculated emissions based on fuel usage data } \\
\text { provided by city and national fuel economy } \\
\text { figures } \\
\text { - Vehicles classified into types using US EPA's fuel } \\
\text { economy website: www.fueleconomy.gov }\end{array}$ \\
\hline Menlo Park & City staff & Fuel usage & - Data presented by department fleet \\
\hline Pittsburg & City staff & $\begin{array}{l}\text { Make, model, } \\
\text { mileage, fuel } \\
\text { purchase for } \\
\text { each vehicle }\end{array}$ & $\begin{array}{l}\text { - Data presented by department fleet } \\
\text { - The following data was collected for each vehicle in } \\
\text { the fleet: make, model, } 2005 \text { VMT, and gasoline } \\
\text { or diesel purchases }\end{array}$ \\
\hline Santa Cruz & $\begin{array}{l}\text { No data source } \\
\text { stated }\end{array}$ & Fuel usage & - Data presented in fuel consumption (in gallons) \\
\hline
\end{tabular}

Source: Author's review of inventory documents of selected California cities 


\subsubsection{Employee Commute sector}

Only four of the eight inventories included a quantification of emissions from the employee commute sector as part of the municipal inventory. Two of those four cities completed an employee commute survey to estimate annual VMT of city employees in the inventory year. Table 2.16 outlines the emissions calculation methodology used by the four inventories as well as a brief summary of the employee commute surveys distributed by two of the cities as part of their respective municipal inventories.

TABLE 2.16: Employee commute sector - emissions calculation methodology and data presentation

\begin{tabular}{|c|c|c|c|}
\hline Jurisdiction & Data source & Data collected & $\begin{array}{l}\text { Summary of emissions calculation methodology } \\
\text { and data presentation }\end{array}$ \\
\hline Benicia & City staff & $\begin{array}{l}\text { Full-time and } \\
\text { part-time } \\
\text { employees, } \\
\text { home cities of } \\
\text { employees }\end{array}$ & $\begin{array}{l}\text { - No employee commute survey was completed } \\
\text { - Assumed all full-time employees drove gas-fueled } \\
\text { vehicles, none carpooled, and each employee took } \\
\text { five round-trips per week for } 47 \text { weeks } \\
\text { - Assumed all part-time employees drove gas-fueled } \\
\text { vehicles, none carpooled, and each employee took } \\
\text { three round-trips per week for } 47 \text { weeks } \\
\text { - Employment counts and home cities provided by } \\
\text { Human Resources }\end{array}$ \\
\hline Chico & $\begin{array}{l}\text { Employee } \\
\text { commute survey }\end{array}$ & $\begin{array}{l}\text { VMT by city } \\
\text { employee for } \\
\text { respective } \\
\text { vehicle type }\end{array}$ & $\begin{array}{l}\text { - Employee commute survey was completed } \\
\text { - Survey results determined average distance from } \\
\text { home to work for each employee, mode split, and } \\
\text { VMT per vehicle type }\end{array}$ \\
\hline Davis & City staff & $\begin{array}{l}\text { Number of } \\
\text { employees in } \\
1990 \text {, zip codes } \\
\text { of employees' } \\
\text { residences }\end{array}$ & $\begin{array}{l}\text { - No employee commute survey was completed } \\
\text { - Zip code of all employees used to determine average } \\
\text { trip length for all employees } \\
\text { - Calculated number of passenger-miles traveled } \\
\text { using the average one-way mileage for employee } \\
\text { trips and estimated total number of trips }\end{array}$ \\
\hline Pittsburg & $\begin{array}{l}\text { Employee } \\
\text { commute survey }\end{array}$ & $\begin{array}{l}\text { Round-trip } \\
\text { mileage, } \\
\text { number of days } \\
\text { worked per } \\
\text { week, journey- } \\
\text { to-work mode, } \\
\text { vehicle type } \\
\text { and vehicle fuel }\end{array}$ & $\begin{array}{l}\text { - Employee commute survey was completed } \\
\text { - Survey distributed through SurveyMonkey.com } \\
\text { - Survey asked about employee commute patterns in } \\
2005 \text { for full-time employees; employee } \\
\text { commute patterns in } 2008 \text { for part-time } \\
\text { employees } \\
\text { - Survey asked for journey-to-work mode, number of } \\
\text { days worked per week, round-trip distance to } \\
\text { work, vehicle type and vehicle fuel }\end{array}$ \\
\hline
\end{tabular}

Source: Author's review of inventory documents of selected California cities 
Rather than distribute an employee commute survey, the Benicia inventory assumed all employees drove alone and drove gas-fueled vehicles. The inventory used an employee's home city when calculating round-trip distance traveled to work. The Davis inventory, which also did not administer an employee commute survey, used an employee's zip code to determine one-way distance to work to estimate annual VMT of city employees in 1990.

The employee commute survey distributed as part of the Chico and Pittsburg inventories included questions about an employee's journey-to-work mode of travel and an employee's vehicle type. The Pittsburg inventory also included a question about an employee's vehicle fuel type as part of the survey.

\subsubsection{Streetlight and Traffic Signal sector}

All but one inventory included a quantification of emissions from streetlights and traffic signals. The emissions calculation methodology requires collecting electricity usage for streetlights and traffic signals in the respective city. Several inventories included additional lighting fixtures including park, specialty or parking lot lighting. The Santa Cruz inventory aggregates lighting in the buildings and facilities sector. Table 2.17 outlines the data sources, data collected and emissions calculation methodology for the streetlight and traffic signal sector. 
TABLE 2.17: Streetlights and traffic signals sector - emissions calculation methodology and data presentation

\begin{tabular}{|c|c|c|c|}
\hline Jurisdiction & Data source $(s)$ & $\begin{array}{c}\text { Energy data } \\
\text { collected }\end{array}$ & $\begin{array}{l}\text { Summary of emissions calculation methodology } \\
\text { and data presentation }\end{array}$ \\
\hline Benicia & $\begin{array}{l}\text { Pacific Gas \& } \\
\text { Electric }\end{array}$ & Electricity & - Electricity usage for streetlights and traffic signals \\
\hline Chico & $\begin{array}{l}\text { No data source } \\
\text { stated }\end{array}$ & Electricity & $\begin{array}{l}\text { - Electricity usage for city- and PG\&E-owned } \\
\text { streetlights, traffic signals, and park lighting }\end{array}$ \\
\hline Davis & $\begin{array}{l}\text { City staff } \\
\text { (1990 energy usage } \\
\text { for city offices); } \\
\text { PG\&E } \\
\text { (historical report on } \\
\text { municipal energy } \\
\text { usage by sector, } \\
\text { 1995-1999) }\end{array}$ & Electricity & $\begin{array}{l}\text { - Data includes electricity usage for road lighting, } \\
\text { specialty or accent lighting, traffic signals, and } \\
\text { other lights operated by city } \\
\text { - Two historical reports were available to assist in } \\
\text { determining energy usage for city buildings }\end{array}$ \\
\hline Hayward & $\begin{array}{l}\text { No data source } \\
\text { stated }\end{array}$ & Electricity & - Electricity usage for streetlights and traffic signals \\
\hline Menlo Park & $\begin{array}{l}\text { No data source } \\
\text { stated }\end{array}$ & Electricity & $\begin{array}{l}\text { Data includes electricity usage for streetlights, } \\
\text { traffic signals, park lighting, decorative lights, and } \\
\text { parking lot lights }\end{array}$ \\
\hline Pittsburg & $\begin{array}{l}\text { Pacific Gas \& } \\
\text { Electric }\end{array}$ & Electricity & - Electricity usage for streetlights and traffic signals \\
\hline Santa Cruz & $\begin{array}{l}\text { No data source } \\
\text { stated }\end{array}$ & Electricity & $\begin{array}{l}\text { - Electricity usage for streetlights and traffic signals } \\
\text { included in buildings sector }\end{array}$ \\
\hline
\end{tabular}

Source: Author's review of inventory documents of selected California cities

\subsubsection{Water and Sewer sector}

All but one of the inventories included a quantification of emissions from the water and sewer sector in the municipal inventory. All seven inventories calculated emissions based on the electricity and natural gas usage by water pump stations, lift stations, and water and wastewater treatment plants. Table 2.18 provides a summary of the data sources, energy data collected and emissions calculation methodology used for the water and sewer sector. 
TABLE 2.18: Water and sewer sector - emissions calculation methodology and data presentation

\begin{tabular}{|c|c|c|c|}
\hline Jurisdiction & Data source(s) & $\begin{array}{c}\text { Energy data } \\
\text { collected }\end{array}$ & $\begin{array}{c}\text { Summary of emissions calculation methodology } \\
\text { and data presentation }\end{array}$ \\
\hline Benicia & $\begin{array}{l}\text { No data source } \\
\text { stated }\end{array}$ & $\begin{array}{l}\text { Electricity and } \\
\text { natural gas }\end{array}$ & $\begin{array}{l}\text { - Data includes energy usage by lift stations, pump } \\
\text { stations, water and wastewater treatment plants }\end{array}$ \\
\hline Chico & $\begin{array}{l}\text { No data source } \\
\text { stated }\end{array}$ & $\begin{array}{l}\text { Electricity and } \\
\text { natural gas }\end{array}$ & $\begin{array}{l}\text { - Operates Water Pollution Control Plant, which } \\
\text { emits } 99 \% \text { of emissions in this sector; WPCP also } \\
\text { emits methane from digesters } \\
\text { - Data available for } 2005,2006,2007\end{array}$ \\
\hline Davis & $\begin{array}{l}\text { City staff } \\
\text { (historical city } \\
\text { records, PG\&E } \\
\text { records) }\end{array}$ & $\begin{array}{l}\text { Annual water } \\
\text { production } \\
\text { energy usage }\end{array}$ & $\begin{array}{l}\text { - Data includes } 1990 \text { energy usage by water and } \\
\text { wastewater treatment facilities, lift stations, and } \\
\text { pump stations }\end{array}$ \\
\hline Hayward & $\begin{array}{l}\text { No data source } \\
\text { stated }\end{array}$ & $\begin{array}{l}\text { Electricity and } \\
\text { natural gas }\end{array}$ & $\begin{array}{l}\text { - Data includes energy usage by water and wastewater } \\
\text { treatment facilities, pump stations, lift stations, } \\
\text { and other water supply infrastructure }\end{array}$ \\
\hline Menlo Park & $\begin{array}{l}\text { City staff } \\
\text { (energy usage } \\
\text { data); } \\
\text { South Bayside } \\
\text { System Authority } \\
\text { (information on } \\
\text { Regional } \\
\text { Treatment Plant) }\end{array}$ & $\begin{array}{l}\text { Electricity and } \\
\text { natural gas }\end{array}$ & $\begin{array}{l}\text { - There is no wastewater treatment plant located in } \\
\text { city; the plant that services city residents is } \\
\text { located in nearby San Carlos and is operated by } \\
\text { South Bayside System Authority. } \\
\text { - SBSA's Regional Treatment Plant serves } 217,000 \\
\text { people; used population share to estimate Menlo } \\
\text { Park's share of wastewater treated; assigned } \\
\text { electricity usage to city (data not included in } \\
\text { inventory) } \\
\text { - To estimate } \mathrm{CH}_{4} \text { and } \mathrm{N}_{2} \mathrm{O} \text { emissions from } \\
\text { wastewater treatment plant attributable to Menlo } \\
\text { Park, national emission figures from wastewater } \\
\text { treatment plants used; per capita amount } \\
\text { multiplied by city's population }\end{array}$ \\
\hline Pittsburg & City staff & $\begin{array}{l}\text { Electricity and } \\
\text { natural gas }\end{array}$ & $\begin{array}{l}\text { - Data includes energy usage for irrigation, pumps, } \\
\text { and water and wastewater treatment plants }\end{array}$ \\
\hline Santa Cruz & $\begin{array}{l}\text { No data source } \\
\text { stated }\end{array}$ & $\begin{array}{l}\text { Electricity and } \\
\text { natural gas }\end{array}$ & $\begin{array}{l}\text { - Emissions generated from water supply and } \\
\text { wastewater systems reported separately } \\
\text { - Reports significant amount of emissions avoided } \\
\text { due to methane cogeneration process at } \\
\text { wastewater treatment plant }\end{array}$ \\
\hline
\end{tabular}

Source: Author's review of inventory documents of selected California cities

The Santa Cruz inventory noted a significant amount of emissions avoided due to the methane cogeneration process at the wastewater treatment plant. A regional treatment plant services the residents and businesses in Menlo Park as no treatment plant is located in and operated by the city. The inventory used the city's population share of the total service area of the regional plant to 
estimate the amount of electricity used to treat the wastewater generated by Menlo Park residents and businesses. A commensurate share of emissions generated by that electricity usage was assigned to Menlo Park. However, the inventory noted these emissions were not included in the inventory.

\subsubsection{Municipal Solid Waste sector}

All but one of the inventories reviewed included a quantification of emissions from the municipal waste sector. Four of the inventories based the emissions calculation on waste tonnage in the inventory year. Two of the inventories identified a waste stream composition as part of the emissions calculation. Data sources for this sector of the municipal inventory included city staff and the disposal company services the community. Table 2.19 provides a summary of the data sources, waste data collected and emissions calculation methodology used for the waste sector.

The Davis inventory estimated 1990 waste tonnage by determining the number of bins in use, the disposal frequency, and the yard or toter to tons conversion. The Hayward inventory used a municipal-specific waste stream composition while the Menlo Park inventory referenced the 2004 Statewide Waste Characterization Study to estimate its waste stream composition based on the waste facilities to which city residents and businesses dispose of their waste ${ }^{39}$.

${ }^{39}$ http://www.calrecycle.ca.gov/WasteChar/WasteStudies.htm\#2004 
TABLE 2.19: Solid Waste sector - emissions calculation methodology and data presentation

\begin{tabular}{|c|c|c|c|}
\hline Jurisdiction & Data source & $\begin{array}{l}\text { Waste data } \\
\text { collected }\end{array}$ & $\begin{array}{c}\text { Summary of emissions calculation methodology } \\
\text { and data presentation }\end{array}$ \\
\hline Benicia & City staff & $\begin{array}{l}\text { Sludge from } \\
\text { water and } \\
\text { wastewater } \\
\text { treatment } \\
\text { plants }\end{array}$ & $\begin{array}{l}\text { - Only wastewater sludge data is included in } \\
\text { inventory, as municipal solid waste data was not } \\
\text { available as a separate account } \\
\text { - City data is included in community inventory } \\
\text { - All waste goes to } 1 \text { landfill, which is the newest } \\
\text { landfill in California and will soon start methane } \\
\text { recovery process }\end{array}$ \\
\hline Chico & $\begin{array}{l}\text { No data source } \\
\text { stated }\end{array}$ & $\begin{array}{l}\text { Waste } \\
\text { generated at } \\
\text { municipal } \\
\text { facilities, } \\
\text { employee waste }\end{array}$ & $\begin{array}{l}\text { - Majority of emissions originated from } \\
\text { decomposition of paper; also includes food waste, } \\
\text { plant debris, and wood and textiles }\end{array}$ \\
\hline Davis & $\begin{array}{l}\text { Davis Waste } \\
\text { Removal }\end{array}$ & $\begin{array}{l}\text { Number of } \\
\text { bins at city } \\
\text { sites, disposal } \\
\text { frequency, yard } \\
\text { (or toter) to } \\
\text { tons conversion }\end{array}$ & $\begin{array}{l}\text { - Includes employee-generated waste, waste generated } \\
\text { at municipal facilities } \\
\text { - Estimates have been made by using information } \\
\text { provided by Davis Waste Removal (number of } \\
\text { bins, disposal frequency, and yard (or toter) to } \\
\text { tons conversion) }\end{array}$ \\
\hline Hayward & City staff & Waste tonnage & $\begin{array}{l}\text { - Data includes municipal-specific waste stream } \\
\text { - Recycling and compost tonnage data not included, } \\
\text { as data set was not complete } \\
\text { - Used a weighted average methane recovery factor }\end{array}$ \\
\hline Menlo Park & $\begin{array}{l}\text { Allied Waste } \\
\text { Services }\end{array}$ & Waste tonnage & $\begin{array}{l}\text { - Waste data includes regular pick-up containers, } \\
\text { roll-off boxes, and public bins } \\
\text { - Waste composition based on California Integrated } \\
\text { Waste Management Board's Waste Characteristic } \\
\text { Study }\end{array}$ \\
\hline Pittsburg & $\begin{array}{l}\text { Garaventa } \\
\text { Enterprise }\end{array}$ & Waste tonnage & $\begin{array}{l}\text { - Waste data includes volume of waste serviced for } \\
\text { each city building or facility }\end{array}$ \\
\hline Santa Cruz & $\begin{array}{l}\text { No data source } \\
\text { stated }\end{array}$ & $\begin{array}{l}\text { Waste } \\
\text { emissions }\end{array}$ & - Reports a high methane recovery rate at landfill \\
\hline
\end{tabular}

Source: Author's review of inventory documents of selected California cities

\subsection{Developing emissions projections and establishing reduction targets}

Based on this review of eight local emissions inventories, it was found that once a baseline

emissions inventory for a community has been established, the next step was to develop an emissions projection to a stated forecast year. The projection was typically developed by extrapolating the baseline emissions based on published annual growth rates for population, employment, and 
households in the respective jurisdiction. This projection, typically termed the "business-as-usual" emissions scenario, provides a projection of potential emissions in a forecast year if no new emission reduction measures were implemented in the jurisdiction.

Once an emissions projection is developed for the forecast year, the next step is to develop an emission reduction target for the designated forecast year. This will be discussed further in section

\section{$\underline{2.5 .2}$.}

\subsubsection{Projections and forecasts for future year}

There was general consensus among the eight inventories on the forecast year selected (see Table 2.20). Seven of the eight inventories used 2020 as the forecast year ${ }^{40}$. The Davis inventory selected 2015 as the projection year. Davis was the only jurisdiction to develop an inventory for 1990, whereas the other seven jurisdictions developed an inventory for 2005. The Benicia inventory also developed an interim forecast for the year 2010 in addition to the forecast for year 2020 .

\section{TABLE 2.20: Determination of forecast year}

\begin{tabular}{|l|l|}
\hline Jurisdiction & \multicolumn{1}{|c|}{ Q31. Was 2020 used as the forecast year? If not, what year was used? } \\
\hline Benicia & 2010 and 2020 projections developed \\
\hline Berkeley & 2020 \\
\hline Chico & 2020 \\
\hline Davis & 2015 was used as the projection year \\
\hline Hayward & 2020 \\
\hline Menlo Park & 2020 \\
\hline Pittsburg & 2020 \\
\hline Santa Cruz & 2020 \\
\hline
\end{tabular}

Source: Author's review of inventory documents of selected California cities

A review of the methodology used by the eight inventories to project emissions to the future year found little consistency in the data inputs and general methodology. However, some consistency was

${ }^{40}$ The year 2020 is important as it relates to AB 32 as one of the three greenhouse gas emission reduction goals of $A B 32$ is to reduce statewide emissions to 1990 levels by 2020 . 
found in terms of the data sources used to develop the methodology. Six of the eight inventories used the socio-economic projections report published by the metropolitan planning organization (MPO) for the region in which the jurisdiction is located ${ }^{41}$. The Davis inventory uses socioeconomic projections from the city's planning department, the region's MPO, and the U.S. Census to develop an emissions projection for 2015 from its 1990 emissions inventory. The two other inventories used multi-year data sets to develop the emissions forecast. The Chico inventory used energy data from years adjacent to the inventory year to develop the forecast. The Santa Cruz inventory developed a trend line from three previous community inventories to project 2020 emission levels.

Limited consistency was found in the general methodology utilized to project emissions to the forecast year (see Table 2.21). Two of the eight inventories (Berkeley and Hayward) simply applied the annual population growth rate to all sectors to develop an emissions projection. The Benicia inventory included projections for employment growth and household growth in addition to population growth to develop an emissions projection, but also assumed a separate growth rate in emissions from the Valero refinery. The Chico inventory developed its emissions projection by extrapolating growth rates from multiple-year data sets for community-wide energy usage, fuel usage and waste tonnage. Two of the eight inventories (Menlo Park and Pittsburg) identified growth rates

\footnotetext{
${ }^{41}$ Five of the jurisdictions (Benicia, Berkeley, Hayward, Menlo Park and Pittsburg) are member jurisdictions of Association of Bay Area Governments (ABAG), the MPO for the nine-county San Francisco Bay Area. Davis is a member jurisdiction of Sacramento Area Council of Governments (SACOG), the MPO for the six-county Sacramento region. One of the responsibilities of an MPO is to make long-term regional forecasts for population, housing, and employment.
} 
TABLE 2.21: Methodology for developing greenhouse gas emissions projections

\begin{tabular}{|c|c|c|c|}
\hline Jurisdiction & Data source(s) & Data inputs & $\begin{array}{c}\text { General methodology used to project emissions } \\
\text { to forecast year }\end{array}$ \\
\hline Benicia & $\begin{array}{l}\text { ABAG Projections } \\
\text { report }\end{array}$ & $\begin{array}{l}\text { Projections for } \\
\text { population, } \\
\text { households, } \\
\text { employment }\end{array}$ & $\begin{array}{l}\text { - Annual growth rate applied to each sector using } \\
\text { growth projections for population, households, and } \\
\text { employment } \\
\text { - Assumed } 1 \% \text { annual growth rate in emissions from oil } \\
\text { refinery }\end{array}$ \\
\hline Berkeley & $\begin{array}{l}\text { ABAG Projections } \\
\text { report }\end{array}$ & $\begin{array}{l}\text { Annual population } \\
\text { growth rate }\end{array}$ & $\begin{array}{l}\text { - Applied population growth rate factors to base year } \\
\text { emissions for all sectors; assumed energy } \\
\text { consumption will grow as population increases } \\
\text { - Assumed no change in municipal emissions }\end{array}$ \\
\hline Chico & $\begin{array}{l}\text { Multiple-year data } \\
\text { sets }\end{array}$ & $\begin{array}{l}\text { Population, house- } \\
\text { holds, businesses, } \\
\text { fuel usage, and } \\
\text { waste tonnage }\end{array}$ & $\begin{array}{l}\text { - Population forecast based on historic annual } \\
\text { percentage increase in population, households, } \\
\text { commercial establishments, waste tonnage, gas, } \\
\text { diesel, natural gas and electricity }\end{array}$ \\
\hline Davis & $\begin{array}{l}\text { U.S. Census, CA } \\
\text { Dept of Finance, CA } \\
\text { Employment } \\
\text { Development Dept., } \\
\text { UC Davis Office of } \\
\text { Info. and Resource } \\
\text { Mgmt, and city staff }\end{array}$ & $\begin{array}{l}\text { Population, } \\
\text { households, } \\
\text { commercial and } \\
\text { industrial employees } \\
\text { and land use for base } \\
\text { year of } 1990 \text { and } \\
\text { forecast year of } 2015\end{array}$ & $\begin{array}{l}\text { - Applied varying projected growth rates for population, } \\
\text { households, commercial and industrial employees, } \\
\text { and non-residential floor area to Year } 2015 \\
\text { - Utilized capacity analysis of non-residential land area } \\
\text { in city and applied historic floor area ratio to } \\
\text { determine projected commercial and industrial } \\
\text { square footage in city }\end{array}$ \\
\hline Hayward & $\begin{array}{l}\text { ABAG Projections } \\
\text { report }\end{array}$ & $\begin{array}{l}\text { Annual population } \\
\text { growth rate }\end{array}$ & $\begin{array}{l}\text { - Applied population growth rate factors to base year } \\
\text { emission figures for residential, commercial / } \\
\text { industrial, and transportation sectors }\end{array}$ \\
\hline Menlo Park & $\begin{array}{l}\text { ABAG Projections } \\
\text { report, } 2 \text { CA Energy } \\
\text { Commission reports, } \\
\text { EPA's Landfill Gas } \\
\text { Emissions Model } \\
\text { (LandGEM) }\end{array}$ & $\begin{array}{l}\text { Population and job } \\
\text { growth projections, } \\
\text { projected growth in } \\
\text { VMT, projected } \\
\text { change in landfill } \\
\text { emissions }\end{array}$ & $\begin{array}{l}\text { - Projected trends in energy use, driving habits, } \\
\text { population and job growth to } 2020 \\
\text { - Residential: average annual population growth rate } \\
\text { - Commercial: job growth projection }{ }^{42} \\
\text { - Transportation: projected growth in energy demand }{ }^{43} \\
\text { - Waste: average annual population growth rate } \\
\text { - Marsh Road Landfill: used LandGEM to estimate } \\
2020 \text { emissions } \\
\text { - Assumed no change in municipal emissions }\end{array}$ \\
\hline Pittsburg & $\begin{array}{l}\text { ABAG Projections } \\
\text { report, } \\
\text { Contra Costa } \\
\text { Transportation } \\
\text { Authority, CIWMB }\end{array}$ & $\begin{array}{l}\text { Projections for } \\
\text { population and job } \\
\text { growth, projected } \\
\text { growth in VMT and } \\
\text { waste tonnage }\end{array}$ & $\begin{array}{l}\text { - Used population growth rate to estimate growth in } \\
\text { residential energy and residential waste; job growth } \\
\text { rate used to estimate growth in commercial waste } \\
\text { - Used projected growth in VMT to estimate growth in } \\
\text { regional and local transportation } \\
\text { - Distributed total job projections to commercial and } \\
\text { industrial sectors based on analysis of General Plan, } \\
\text { then estimated commercial and industrial emissions }\end{array}$ \\
\hline Santa Cruz & $\begin{array}{l}\text { Data from previous } \\
\text { emissions inventories }\end{array}$ & $\begin{array}{l}\text { No reference to any } \\
\text { indicator data }\end{array}$ & $\begin{array}{l}\text { - Estimates } 2020 \text { emissions projection based on } 1996 \text {, } \\
\text { 2000, and } 2005 \text { inventories }\end{array}$ \\
\hline
\end{tabular}

Source: Author's review of inventory documents of selected California cities

${ }^{4}$ Analysis from the California Energy Commission's report, “California Energy Demand 2008-2018: Staff Revised Forecast", was used to establish that energy use closely tracks growth in commercial floor space and number of jobs. ${ }^{43}$ Analysis from the California Energy Commission's report, "Forecast of Transportation Energy Demand, 2003-2023", was used to determine that vehicle-miles of travel are projected to increase at an annual rate of $1.65 \%$ through 2023 . 
specific to the different sectors to develop their respective emissions projections. In order to develop a more accurate projection of growth in the commercial and industrial sectors, two of the inventories (Davis and Pittsburg) included a capacity analysis of commercial and industrial land area within each respective jurisdiction. The Santa Cruz inventory based its emissions projection for 2020 on three previous community inventories.

\subsubsection{Reduction targets for future year}

Following ICLEI's Cities for Climate Protection campaign process, once an emissions projection for the forecast year is developed, the next step is to establish a reduction target for the designated forecast year. It is usually expressed as a percentage reduction below the quantity of emissions in the baseline year by the forecast year. An example of a reduction target might be a 20 percent reduction in greenhouse gas emissions below 2000 base year levels by the target year $2010^{44}$. If the projected "business-as-usual" emissions scenario estimates an increase in emissions by the target year, the actual reduction in emissions will be greater than the stated percent reduction ${ }^{45}$.

In its Cities for Climate Protection Milestone Guide, ICLEI suggests that the importance of setting an emission reduction target is that it "gives the Climate Action Plan a tangible, specific goal without

${ }^{44}$ Cities for Climate Protection Milestone Guide, ICLEI, page 32.

${ }^{45}$ For example, if a jurisdiction adopted a reduction target of $20 \%$ reduction in emissions below 2000 base year levels by the target year 2010, and that jurisdiction's 2000 emissions were 1 million tons of carbon dioxide equivalents, it would need to reduce community emissions to 800,000 tons in 2010 . However, if the "business-as-usual" emissions scenario projects a $20 \%$ increase in emissions from 2000 to 2010 , then the actual emissions reduction from the emissions projection would be 400,000 tons from 2000 to 2010 (1,000,000 times 1.2 is 1,200,000; 1,200,000 minus 800,000 is $400,000)$. This example underscores the importance of establishing a reasonable projection of emissions for the forecast year. 
which the Plan would merely be a collection of nice ideas and strategies" and "provides an objective toward which to strive and against which to measure progress" ${ }^{46}$.

It is not necessary for the jurisdiction to establish a reduction target as part of developing the baseline emissions inventory. Of the eight inventories reviewed, only four include a reduction target as part of the inventory. Two of these four inventories consider more than one potential reduction target, suggesting further consideration would be necessary before identifying a single reduction target for adoption by the city's decision-making body. Table 2.22 describes the potential reduction targets identified by the four jurisdictions that did include a reduction target as part of the inventory document.

TABLE 2.22: Establishment of greenhouse gas emission reduction target

\begin{tabular}{|c|c|}
\hline Jurisdiction & Q30. Was a GHG reduction target established? If so, what is reduction target? \\
\hline Benicia & $\begin{array}{l}\text { Four reduction targets described: } \\
\text { - } 25 \% \text { below } 2000 \text { level in } 2010 \text { (Municipal) } \\
\text { - } 33 \% \text { below } 2000 \text { level in } 2020 \text { (Municipal) } \\
\text { - } 10 \% \text { below } 2000 \text { level by } 2020 \text { (Community) } \\
\text { - maintain } 2005 \text { level in } 2010 \text { (Community) }\end{array}$ \\
\hline Berkeley & No reduction target established in inventory \\
\hline Chico & $\begin{array}{l}\text { Four potential reduction targets described: } \\
\text { - } 20 \text { or } 25 \% \text { below } 2005 \text { level by } 2020 \\
\text { - } 15 \% \text { below } 2005 \text { level by } 2015 \\
\text { - } 10 \% \text { below } 2005 \text { level by } 2010\end{array}$ \\
\hline Davis & $15 \%$ below 1990 levels by 2015 \\
\hline Hayward & No reduction target established in inventory \\
\hline Menlo Park & No reduction target established in inventory \\
\hline Pittsburg & No reduction target established in inventory \\
\hline Santa Cruz & $30 \%$ reduction by $2020,80 \%$ reduction by 2050 compared to 1990 levels \\
\hline
\end{tabular}

Source: Author's review of inventory documents of selected California cities

The Benicia inventory suggests two possible community-wide reduction targets as well as two possible reduction goals for municipal operations. The inventory acknowledges the limited authority the City has over businesses in its community to reduce emissions, and therefore suggests a modest

\footnotetext{
${ }^{46}$ Cities for Climate Protection Milestone Guide, ICLEI, page 32.
} 
interim reduction target of maintaining 2005 emissions level in 2010. For the long-term reduction target for 2020, the document points out that technological innovation may aid in reducing industrial emissions in the coming years; therefore, the document suggests a reduction target closely aligned to that established by the state: 10 percent reduction from 2000 levels in 2020 .

The reduction targets suggested for the Benicia municipal operations are more aggressive, as the City has greater control over emission reduction measures for municipal facilities and operations. In establishing two targets - 25 percent reduction from 2000 levels in 2010 and 33 percent reduction from 2000 levels in 2020 - the document points out that the City has achieved a 20 percent reduction from 2000 levels in 2005, and suggests that the City could continue to reduce emissions from its municipal operations in future years.

The Chico inventory suggested that the emissions reduction target adopted should be ambitious, attainable, and agreeable. The inventory suggested four potential reduction targets for consideration by the city's decision-making body. The reduction targets ranged from a 1.67 to 5.00 percent annual reduction in emissions, and included forecast years of 2010, 2015, and 2020.

As part of the target-setting process, the Davis inventory provided a table of emission reduction targets of city and county jurisdictions in northern California that have established emissions reduction targets for purposes of comparison. The emissions reduction target suggested in the inventory (15 percent below 1990 levels by 2015) was similar to the example reduction targets provided, but was presented as an example reduction target.

In the target-setting process, the Santa Cruz inventory has the advantage of having historic data available to help establish reduction goals. The City had completed community-wide inventories for 
1996, 2000, and 2005. As of 2005, Santa Cruz has experienced an 11 percent reduction in community emissions since 1996. Although 1990 levels for the City of Santa Cruz were not available, the City was able to extrapolate 1990 emissions based on their 1996 levels and available countywide emissions data for those years. Having a 1990 emissions estimate allows the City to align its reduction goals to those set forth by AB 32, which use 1990 statewide levels as the key base year. Therefore, the City has a clear objective of the emission reductions that it strives to achieve by 2020 and, in the long-term, by 2050 .

\subsection{Conclusions}

This detailed review of eight community emissions inventories in California has generally revealed there is limited consistency in the data sources used to devise emission estimates for specific sectors of the community-wide inventory. There is also limited consistency in the overall organization and presentation of data among the eight inventories reviewed.

The eight inventories are consistent in the overall framework for their development. All eight jurisdictions joined ICLEI's Cities for Climate Protection campaign. Communities that join the campaign pledge to complete five milestones, the first of which is to conduct a baseline emissions inventory and forecast. Membership with ICLEI also grants communities access to ICLEI's Clean Air Climate Protection software, which allows the user to quantify greenhouse gas emissions for their community. As the software is organized to produce a two-level inventory (community and municipal), the organization of the eight inventories is consistent.

Utilizing the same emissions accounting software lends itself to create consistency in the overall organization of the emissions inventories among jurisdictions. This consistency was apparent as most 
of the inventories analyzed emissions from the same sectors in both the community and municipal inventories. In the community inventory, there was limited consistency regarding commercial and industrial emissions. Several inventories combined industrial emissions with commercial emissions due to either data availability or data confidentiality issues. A few inventories did not report industrial emissions due to limited or no industrial presence within the community, while two jurisdictions reported industrial emissions as constituting nearly all community emissions, underscoring the major presence the industrial sector has in those two jurisdictions.

It is evident there is limited consistency among the eight inventories for the transportation sector. As the sector that generated the highest per capita emissions for six of the eight inventories reviewed - the other two being the jurisdictions with the major industrial presence - it would be prudent to have a consistent methodology for the calculation of emissions generated by mobile sources in a community. This is not the case, as the data collection methodologies by the eight jurisdictions to calculate transportation emissions varied significantly. Several different sources were identified to determine vehicle-miles of travel for highways and city streets; various sources were identified for determining the vehicle distribution in a given community; and several methodologies utilized to convert daily vehicle-miles of travel into annual vehicle-miles of travel.

In the municipal operations inventory, there was limited consistency among the eight inventories in terms of data organization and presentation of results. Although the eight inventories generally included a quantification of emissions for the six municipal sectors presented in this analysis, the presentation of results were inconsistent from one inventory to another. For example, results for the buildings and facilities sector were presented in three different ways for the eight inventories - 
emissions disaggregated by city building, emissions disaggregated by facility type, and total emissions for all city buildings combined. The recent publication of the Local Government Operations Protocol will allow communities to report emissions based on a standard reporting protocol. Additionally, future municipal inventories can be organized in terms of emissions scopes, which will allow communities to identify the emissions over which they have more control and can work to reduce. See section 3.7 for a discussion of emission scopes.

Five of the eight inventories identified 2005 as the baseline year, while two other jurisdictions conducted an interim inventory for year 2005. Only one jurisdiction developed an inventory using 1990 as the baseline year. Many jurisdictions in California are conducting or have conducted an emissions inventory using 2005 as the baseline year, which allows for comparison throughout the state using a common baseline year.

Although most inventories project emissions to the same forecast year (2020), there is limited consistency in the methodology to develop the "business-as-usual" emissions projection. A few of the inventories simply project growth in emissions based on the annual population growth rate, whereas other inventories project emissions based on varying growth rates. As an example, in one inventory reviewed, annual population growth rate was used to project emissions from residential waste, while total job growth rate used to project emissions from commercial waste.

Improved consistency in the development of the community and municipal emissions inventory and forecast is important as communities strive to develop policies that work to reduce greenhouse gas emissions in the future. The baseline emissions inventory serves as a reference against which a jurisdiction can measure their progress toward meeting their greenhouse gas reduction goals and 
targets. Standardizing the inventory process will create a process that can be easily replicated by local jurisdictions and will allow communities across the state to evaluate the effectiveness of policies and programs meant to reduce local greenhouse gas emissions. 


\section{Chapter 3: COMMUNITY AND MUNICIPAL OPERATIONS INVENTORY METHODOLOGY}

This chapter discusses the many different components involved in the development of the community and municipal inventories. This includes a discussion on the following: the organization of the project; the establishment of baseline and forecast years; the organizational boundary of the jurisdiction; the local government emissions inventory protocol; the greenhouse gases to be assessed; emissions scopes; the emissions accounting software; data sources; and the data collection methodology for community and municipal sectors.

\subsection{Project organization}

This local greenhouse gas emissions inventory is organized in two inventory levels. Essentially, two inventories are developed as part of this process: one for community emissions and one for municipal emissions. The community inventory provides an estimate of all greenhouse gas emissions generated in San Luis Obispo by residents, businesses, and municipal operations in the year 2005. Five primary sectors are included in the community inventory - residential, commercial, industrial, transportation, and solid waste.

The municipal inventory accounts for emissions generated by city buildings and facilities, city operations, the vehicular emissions from commutes of city employees and the municipal vehicle fleet and emissions generated by municipal solid waste. Results are organized in the following sectors: buildings and facilities, vehicle fleet, employee commute, streetlights and traffic signals, water delivery, wastewater, municipal solid waste, and employee business travel in private vehicles. The municipal inventory is meant to be a subset of the community inventory. 
The municipal inventory is more detailed than the community inventory because the data is more refined; it includes detail for more sectors and identifies specific point sources of emissions.

\subsection{Baseline and forecast years}

The baseline year used for both the community and municipal emissions inventory was 2005 . The primary reason that 2005 was chosen as the baseline year was that it was a common year of data availability for all sectors of the two inventories. Additionally, many communities in California that have already completed an emissions inventory used the same year. As a result, it may be possible to compare the results of this inventory other communities in the region and the state.

\subsection{Organizational boundary}

Due to the fact that local governments vary in their legal and organizational structures, it is important to establish the local government's organizational boundary for greenhouse gas emissions accounting and reporting. Local governments should report their emissions according to one of two control approaches: operational control or financial control. The Local Government Operations Protocol (Protocol) suggests that municipal inventories utilize operational control when defining the organizational boundary of the emissions inventory. Operational control is the consolidation approach required under $\mathrm{AB}$ 32's mandatory reporting program and is consistent with the requirements of many other environmental and air quality reporting ${ }^{47}$.

\footnotetext{
${ }^{47}$ California Air Resources Board, AB 32 Scoping Plan, Sacramento, California, December 2008, page 14.
} 
According to the Protocol (discussed in section 3.5), a local government has operational control of an emissions source if the local government has the full authority to introduce and implement policies for the operation. One or more of the following conditions establishes operational control:

- Wholly owning an operation, facility, or source; (such as the city's water reclamation facility)

- Having the full authority to introduce and implement operation and health, safety and environmental policies (such as policies to reduce the use of paper products in city offices).

Under this approach, a local government is responsible for 100 percent of emissions from operations over which it has control.

\subsection{Local government emissions inventory protocol}

The Local Government Operations Protocol (Protocol) is designed to provide a standardized set of guidelines to assist local governments in quantifying and reporting greenhouse gas emissions associated with their government operations. The Protocol was developed jointly by CARB, ICLEI, California Climate Action Registry (CCAR), and The Climate Registry. The Protocol provides a standardized mechanism for inventorying emissions, which can help track emission reduction progress over time and in comparison to emission reduction targets ${ }^{48}$.

There are plans to publish an emissions reporting protocol to assist in the development of standardized community emissions inventories. The manual for the Clean Air Climate Protection Software provides direction for the collection of data necessary to complete community and municipal inventories. The software is discussed in section 3.8. Where possible, the methodologies utilized in the Protocol were applied to the community inventory.

\footnotetext{
${ }^{48}$ http://www.icleiusa.org/programs/climate/ghg-protocol
} 


\subsection{Greenhouse gases to be assessed}

All six internationally-recognized greenhouse gas emissions regulated under the Kyoto Protocol are intended to be assessed by this inventory: carbon dioxide $\left(\mathrm{CO}_{2}\right)$; methane $\left(\mathrm{CH}_{4}\right)$; nitrous oxide $\left(\mathrm{N}_{2} \mathrm{O}\right)$; hydrofluorocarbons (HFCs); perfluorocarbons (PFCs); and sulfur hexafluoride $\left(\mathrm{SF}_{6}\right)^{49}$. As discussed in section 3.8, the emissions accounting software quantifies all emissions in terms of carbon dioxide equivalent $\left(\mathrm{CO}_{2} \mathrm{e}\right)$ emissions. The varying heat-trapping attributes (i.e., global warming potential) of the six greenhouse gases make it is necessary to convert all gases to a common metric in order to produce a meaningful inventory.

\subsection{Emissions scopes}

In an effort to provide an effective framework for developing different types of climate action policies and goals, the Protocol follows the GHG Protocol Corporate Standard, developed by the World Resources Institute and the World Business Council for Sustainable Development (WRI/WBCSD), in categorizing direct and indirect emissions into three scopes.

Scope 1 emissions include all direct emissions generated by sources located within the jurisdiction's boundary. Examples of Scope 1 sources include use of fuels such as heavy fuel oil, natural gas, or propane used for heating.

\footnotetext{
${ }^{49}$ Kyoto Protocol to the United Nations Framework Convention on Climate Change, United Nations, 1998, http://unfccc.int/essential background/kyoto protocol/items/1678.php.
} 
Scope 2 emissions include indirect emissions generated by purchased electricity. Scope 2 emissions physically occur at the facility where electricity is generated ${ }^{50}$. These emissions should be included in the community inventory, as they are the result of electricity usage.

Scope 3 emissions are all other indirect and embodied emissions that occur as a result of activity within the jurisdictional boundary. Examples of Scope 3 emissions include methane emissions from solid waste generated within the community which decomposes at landfills either inside or outside of the community's boundary.

Taken together, the three scopes provide a comprehensive accounting framework for managing and reducing direct and indirect emissions. Local governments should, at a minimum, quantify and report all Scope 1 and Scope 2 emissions ${ }^{51}$. The reporting of Scope 3 emissions is optional and at the present time lacks a standard practice. Local governments should address the collection of Scope 3 emissions from a policy perspective, and focus on emissions that could be reduced by changes in local government policy. Figure 3.1 provides an overview of the relationship between the scopes and the activities that generate direct and indirect emissions at the municipal- and community- level.

\footnotetext{
${ }^{50}$ As an example, electricity generated at a coal power plant is considered as Scope 1 emissions; when electricity is purchased, distributed and consumed by a city building many miles away from the power plant, it is considered as Scope 2 emissions.

${ }^{51}$ California Air Resources Board, AB 32 Scoping Plan, Sacramento, California, December 2008, page 22.
} 


\section{FIGURE 3.1: Overview of scopes and emissions}

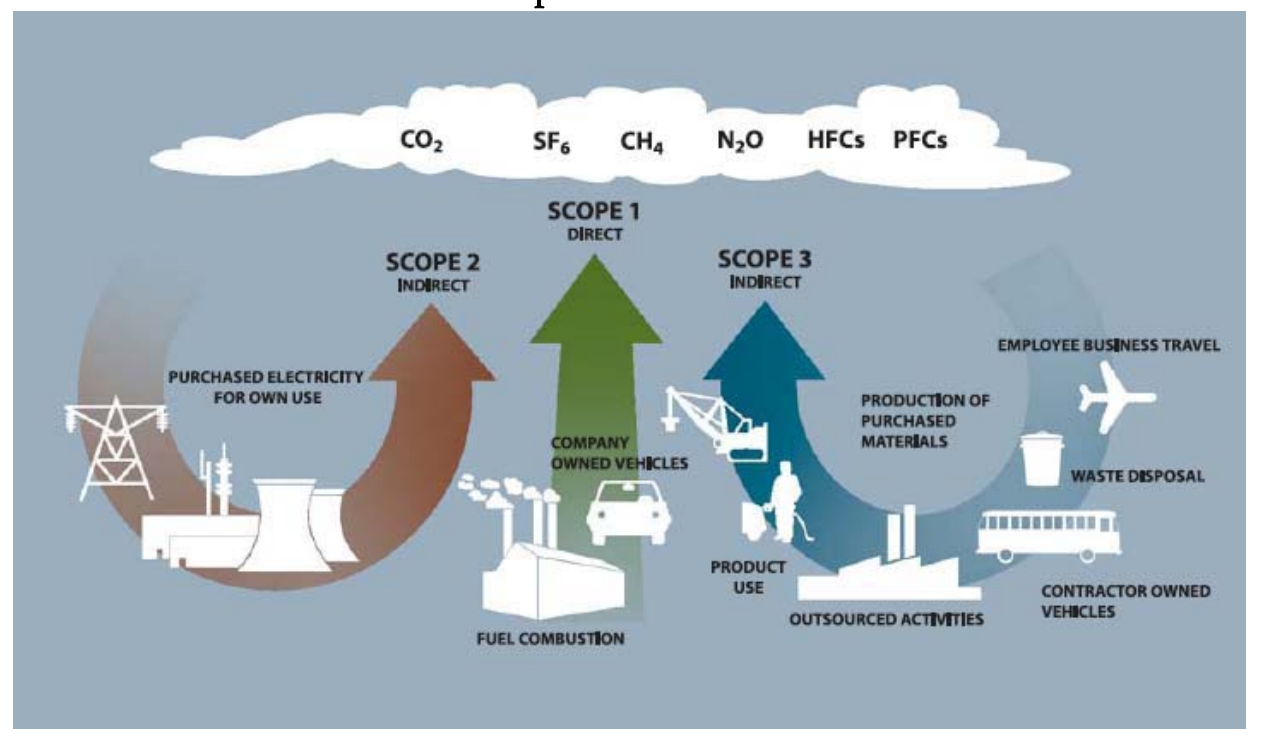

Source: WRI/WBCSD GHG Protocol - A Corporate Accounting and Reporting Standard (Revised Edition), Chapter 4.

\subsection{Emissions accounting software}

To facilitate community efforts to reduce greenhouse gas emissions, ICLEI developed the Clean Air and Climate Protection (CACP) software package in partnership with the State and Territorial Air Pollution Program Administrators (STAPPA), the Association of Local Air Pollution Control Officials (ALAPCO) ${ }^{52}$, and Torrie Smith Associates. The software calculates emissions resulting from energy consumption, fuel usage, and waste generation. The CACP software determines emissions using specific factors (or coefficients) according to the type of fuel used. Greenhouse gas emissions are aggregated and reported in terms of carbon dioxide equivalents $\left(\mathrm{CO}_{2} \mathrm{e}\right)$ emissions. Converting all emissions to carbon dioxide equivalent emissions allows for the consideration of different greenhouse gases in comparable terms.

\footnotetext{
${ }^{52}$ STAPPA and ALAPCO are now collectively known as the National Association of Clean Air Agencies (NACAA).
} 


\subsection{Data sources}

Energy usage, fuel usage, and waste figures were collected from a wide variety of sources to complete the community inventory. Where possible, data for years adjacent to 2005 was collected in order to create a basis of comparison. Where data was not available for the year 2005, a proxy year was used. Data sources and data availability for the community inventory are summarized in Table 3.1.

TABLE 3.1: Data sources for community emissions inventory

\begin{tabular}{|c|c|c|c|c|c|}
\hline Sector & $\begin{array}{c}\text { Emissions } \\
\text { Source }\end{array}$ & $\begin{array}{l}\text { What was } \\
\text { measured }\end{array}$ & $\begin{array}{c}\text { Unit of } \\
\text { Measurement }\end{array}$ & Data Source(s) & $\begin{array}{c}\text { Year(s) of data } \\
\text { availability }\end{array}$ \\
\hline \multirow[b]{2}{*}{ Residential } & $\begin{array}{l}\text { Electricity } \\
\text { consumption }\end{array}$ & $\begin{array}{c}\text { aggregated } \\
\text { residential units }\end{array}$ & $\mathrm{kWh}$ & PG\&E & 2003 to 2005 \\
\hline & $\begin{array}{l}\text { Natural gas } \\
\text { consumption }\end{array}$ & $\begin{array}{l}\text { aggregated } \\
\text { residential units }\end{array}$ & therms & $\begin{array}{l}\text { Southern Calif. } \\
\text { Gas Co/Sempra } \\
\text { Energy }\end{array}$ & 2005 to 2007 \\
\hline \multirow{2}{*}{$\begin{array}{l}\text { Commercial/ } \\
\text { Industrial }^{(a)}\end{array}$} & $\begin{array}{l}\text { Electricity } \\
\text { consumption }\end{array}$ & $\begin{array}{c}\text { aggregated } \\
\text { commercial \& } \\
\text { industrial } \\
\end{array}$ & $\mathrm{kWh}$ & PG\&E & 2003 to 2005 \\
\hline & $\begin{array}{l}\text { Natural gas } \\
\text { consumption }\end{array}$ & $\begin{array}{c}\text { aggregated } \\
\text { commercial \& } \\
\text { industrial } \\
\end{array}$ & therms & $\begin{array}{l}\text { Southern Calif. } \\
\text { Gas Co/Sempra } \\
\text { Energy }\end{array}$ & 2005 to 2007 \\
\hline Transportation & $\begin{array}{l}\text { Vehicle travel } \\
\text { on roadways } \\
\text { within city } \\
\text { limits }\end{array}$ & $\begin{array}{l}\text { vehicle-miles of } \\
\text { travel on city- } \\
\text { maintained } \\
\text { roadways and traffic } \\
\text { on U.S. } 101 \\
\text { through city } \\
\text { (b) }\end{array}$ & $\begin{array}{c}\text { vehicle-miles } \\
\text { of travel }\end{array}$ & $\begin{array}{l}\text { City of San Luis } \\
\text { Obispo, Public } \\
\text { Works Dept. } \\
\text { traffic counts } \\
\text { program; Caltrans' } \\
\text { Traffic Data } \\
\text { Branch } \\
\end{array}$ & $\begin{array}{c}\text { 2005/2006 } \\
\text { (city-wide } \\
\text { traffic counts); } \\
2005 \\
\text { (Caltrans' state } \\
\text { highway traffic } \\
\text { counts) } \\
\end{array}$ \\
\hline Solid Waste & All waste types & $\begin{array}{l}\text { Solid waste tonnage } \\
\text { sent to landfills } \\
\text { from activities in } \\
\text { city }\end{array}$ & tons & $\begin{array}{l}\text { San Luis Garbage; } \\
\text { City of San Luis } \\
\text { Obispo, Utilities } \\
\text { Department }\end{array}$ & 2005 to 2007 \\
\hline
\end{tabular}

Notes:

(a) Electricity usage for the industrial sector is included in commercial sector due to confidentiality restrictions.

(b) Vehicle-miles are distributed by type (i.e., percent trucks, passenger vehicles, etc.) based on a distribution of vehicle types provided by the San Luis Obispo County Air Pollution Control District.

The primary sources of data for the municipal inventory were the Utilities Department and Public Works Department. An employee commute survey was distributed to city employees using 
staff email addresses. Data for employee business travel in private vehicles was collected for five of

the city departments. Table 3.2 identifies the data sources utilized in the municipal inventory.

TABLE 3.2: Data sources for municipal emissions inventory

\begin{tabular}{|c|c|c|c|c|c|c|}
\hline Sector & $\begin{array}{c}\text { Emissions Source and } \\
\text { Cost Data }\end{array}$ & $\begin{array}{l}\text { What was } \\
\text { measured }\end{array}$ & Units & $\begin{array}{c}\text { Data } \\
\text { Source(s) }\end{array}$ & Contact(s) & Year $(s)$ \\
\hline \multirow{2}{*}{$\begin{array}{l}\text { Buildings and } \\
\text { Facilities }\end{array}$} & $\begin{array}{l}\text { Energy usage } \\
\text { (electricity and natural } \\
\text { gas) }\end{array}$ & \multirow{2}{*}{$\begin{array}{l}\text { all city buildings } \\
\text { and facilities }\end{array}$} & $\begin{array}{l}\text { kWh and } \\
\text { therms }\end{array}$ & $\begin{array}{l}\text { Utilities } \\
\text { Dept. }\end{array}$ & $\begin{array}{l}\text { Alice Carter } \\
\text { (Ron Munds) }\end{array}$ & $\begin{array}{l}2005 \text { to } \\
2007\end{array}$ \\
\hline & Energy cost data & & $\begin{array}{l}\$ / \mathrm{kWh} \text { and } \\
\$ / \text { therm }\end{array}$ & $\begin{array}{l}\text { Utilities } \\
\text { Dept. }\end{array}$ & Carter/Munds & $\begin{array}{l}2005 \text { to } \\
2007\end{array}$ \\
\hline \multirow[t]{2}{*}{ Vehicle Fleet } & VMT for city vehicles & \multirow{2}{*}{$\begin{array}{l}\text { all city vehicles, by } \\
\text { fuel type, by } \\
\text { vehicle type }\end{array}$} & $\begin{array}{l}\text { VMT by } \\
\text { fuel type } \\
\text { by vehicle } \\
\text { type }\end{array}$ & $\begin{array}{l}\text { Public } \\
\text { Works } \\
\text { Dept. }\end{array}$ & Dave Smith & $\begin{array}{l}\text { FY06-07 } \\
\text { and } \\
\text { FY07-08 }\end{array}$ \\
\hline & Fuel cost data & & \$/gallon & $\begin{array}{l}\text { Public } \\
\text { Works } \\
\text { Dept. }\end{array}$ & Dave Smith & $\begin{array}{l}\text { FY06-07 } \\
\text { and } \\
\text { FY07-08 }\end{array}$ \\
\hline $\begin{array}{l}\text { Employee } \\
\text { Commute }\end{array}$ & $\begin{array}{l}\text { Annual VMT for } \\
\text { employee commute }\end{array}$ & $\begin{array}{l}\text { Survey } \\
\text { respondents } \\
(\mathrm{N}=250)\end{array}$ & VMT & $\begin{array}{l}\text { Employee } \\
\text { survey } \\
\text { (distributed } \\
\text { by email) }\end{array}$ & Kim Murry & 2007 \\
\hline \multirow{2}{*}{$\begin{array}{l}\text { Traffic Signals } \\
\text { and Streetlights }\end{array}$} & $\begin{array}{l}\text { Streetlight and traffic } \\
\text { signal electricity usage }\end{array}$ & \multirow{2}{*}{$\begin{array}{l}\text { all city-maintained } \\
\text { streetlights } \& \\
\text { traffic signals }\end{array}$} & $\mathrm{kWh}$ & $\begin{array}{l}\text { Utilities } \\
\text { Dept. }\end{array}$ & Carter/Munds & $\begin{array}{l}2005 \text { to } \\
2007\end{array}$ \\
\hline & Energy cost data & & $\$ / \mathrm{kWh}$ & $\begin{array}{l}\text { Utilities } \\
\text { Dept. }\end{array}$ & Carter/Munds & $\begin{array}{l}2005 \text { to } \\
2007\end{array}$ \\
\hline \multirow{2}{*}{ Water Delivery } & $\begin{array}{l}\text { Electricity usage by } \\
\text { water delivery system } \\
\text { (electricity) }\end{array}$ & \multirow{2}{*}{$\begin{array}{l}\text { all water delivery } \\
\text { facilities }\end{array}$} & $\mathrm{kWh}$ & $\begin{array}{l}\text { Utilities } \\
\text { Dept. }\end{array}$ & Carter/Munds & $\begin{array}{l}2005 \text { to } \\
2007\end{array}$ \\
\hline & Energy cost data & & $\$ / \mathrm{kWh}$ & $\begin{array}{l}\text { Utilities } \\
\text { Dept. }\end{array}$ & Carter/Munds & $\begin{array}{l}2005 \text { to } \\
2007\end{array}$ \\
\hline \multirow[t]{2}{*}{ Wastewater } & $\begin{array}{l}\text { Electricity usage by } \\
\text { wastewater system } \\
\text { (electricity and natural } \\
\text { gas) }\end{array}$ & \multirow[t]{2}{*}{$\begin{array}{l}\text { all wastewater } \\
\text { delivery facilities }\end{array}$} & $\begin{array}{l}\mathrm{kWh} \text { and } \\
\text { therms }\end{array}$ & $\begin{array}{l}\text { Utilities } \\
\text { Dept. }\end{array}$ & Carter/Munds & $\begin{array}{l}2005 \text { to } \\
2007\end{array}$ \\
\hline & Energy cost data & & $\begin{array}{l}\$ / \mathrm{kWh} \text { and } \\
\$ / \text { therm }\end{array}$ & $\begin{array}{l}\text { Utilities } \\
\text { Dept. }\end{array}$ & Carter/Munds & $\begin{array}{c}2005 \text { to } \\
2007\end{array}$ \\
\hline $\begin{array}{l}\text { Municipal Solid } \\
\text { Waste }\end{array}$ & $\begin{array}{l}\text { Quantity of waste } \\
\text { generated by municipal } \\
\text { facilities }\end{array}$ & $\begin{array}{l}\text { waste generated by } \\
\text { municipal facilities }\end{array}$ & tons & $\begin{array}{l}\text { Utilities } \\
\text { Dept. }\end{array}$ & $\begin{array}{l}\text { Doug } \\
\text { Dowden }\end{array}$ & 2007 \\
\hline $\begin{array}{c}\text { Employee } \\
\text { Business Travel }\end{array}$ & $\begin{array}{l}\text { Annual VMT for } \\
\text { employee business } \\
\text { travel }\end{array}$ & $\begin{array}{c}\text { all municipal } \\
\text { departments with } \\
\text { available records }\end{array}$ & VMT & $\begin{array}{l}\text { various } \\
\text { departments }\end{array}$ & $\begin{array}{l}\text { Kim Murry, } \\
\text { staff in } \\
\text { various } \\
\text { departments }\end{array}$ & $2005^{(a)}$ \\
\hline
\end{tabular}

Note:

(a) The year 2008 was used as a proxy year in some cases where data was not available. 


\subsection{Community inventory data collection methodology}

\subsubsection{Residential sector}

The residential sector calculates energy use and associated emissions for residential buildings within San Luis Obispo. Electricity and natural gas are the two primary energy sources utilized by the vast majority of households in San Luis Obispo, and for which data is available.

A representative from PG\&E provided electricity figures for all residential users within San Luis Obispo. This included the number of residential customers and the community-wide electricity usage figures (in kilowatt-hours). Figures were available for 2003, 2004, and 2005. A representative from Southern California Gas Company provided natural gas figures for all residential customers within San Luis Obispo. Natural gas usage data was available for 2005, 2006, and 2007; usage is reported in decatherms.

\subsubsection{Commercial and Industrial sectors}

The commercial and industrial sectors calculate energy use and associated emissions for commercial and industrial businesses in the community. Electricity and natural gas are the two primary energy sources utilized by the vast majority of businesses in San Luis Obispo, and for which data is available.

A representative from PG\&E provided electricity figures for all commercial users within San Luis Obispo. This included the number of commercial customers and the community-wide electricity usage figures (in kilowatt-hours). Commercial electricity usage figures included industrial businesses due to the "15/15 Rule", an industry confidentiality ruling established by the California Public Utilities Commission. Figures were available for 2003, 2004, and 2005. A representative from 
Southern California Gas Company provided natural gas figures for all commercial users within San Luis Obispo. Industrial natural gas usage was available, but was aggregated with commercial natural gas usage, as it was necessary to combine electricity usage data for the two sectors. Natural gas usage data was available for 2005, 2006, and 2007; usage is reported in decatherms.

\subsubsection{Transportation sector}

The transportation sector calculates total vehicle-miles of travel within the city limits on citymaintained roadways by commercial and private vehicles. There are three state highways (U.S. 101, SR-1 and SR-227) that travel through the community. A determination must be made as to what mileage should be counted toward the total vehicle-miles of travel (VMT) figure for the community. This estimate is validated by comparing results with the Caltrans-maintained public road data and federal highway statistics data. See section 4.4 for a discussion of this comparison.

The primary source of data is the City of San Luis Obispo's traffic counts program. At the time of the inventory, the most recent complete counts were the 2005-2006 traffic counts. The traffic counts program includes data for all of the follow roadway types in the city:

- Major Arterials

- Minor Arterials

- Collectors

- County Highways

- Highways

- Highway Ramps

Among other information, the traffic counts program provides peak Average Daily Trips (ADT, traffic volumes) for 176 local roadway segments (non-highway). For instance, Broad Street includes 17 segments along its entire length, as it transitions from a local collector at the north end of the city 
(near Foothill), travels through downtown, and becomes a major arterial/state highway at the south end of the city to the southern city limits (near Aero Drive). Because this roadway facility serves in these varying capacities, there are vastly different traffic volumes at the south end of the roadway (exceeding 25,000 ADT) from the north end of the roadway (around 5,000 ADT). Additionally, each of the 17 segments has varying lengths.

Vehicle-miles of travel figures are commonly calculated by using the following formula:

(i) Segment length X Average daily traffic = Daily vehicle-miles of travel

(ii) Daily vehicle-miles of travel X 365 days = Annual vehicle-miles of travel

Segment lengths were calculated by using the City's geographic information systems (GIS) roadway network shape file to determine the segment length in miles. Shape files were created to reflect the 176 local roadway segments included in the traffic counts program, as well as the 46 highway segments and highway ramps.

Several county highways are not in the city limits, but are major roadways that connect directly into the city-maintained roadway network; and therefore were included in the evaluation. For example, Highland (from city limits to Mt. Bishop) connects east of Santa Rosa Street/SR-1 toward the California Polytechnic State University, San Luis Obispo campus. Also, southern portions of the city are connected by a section of Tank Farm Road (between South Higuera Street and Broad Street/SR-227), which is a county-maintained roadway.

It was determined to be necessary to count VMT on this section of Tank Farm Road, as the city recently annexed property north and south of Tank Farm Road to accommodate future residential 
and commercial development in these areas ${ }^{53}$. It is necessary to include VMT occurring on this roadway segment in the process of establishing the baseline VMT figures, in order to track changes in VMT on this particular roadway. For the same reason, traffic volumes on Orcutt Road (between Johnson Avenue and Tank Farm Road) were included in the baseline VMT figures, as future residential and commercial development is planned on property located between Orcutt Road, Tank Farm Road and the Union Pacific Railroad ${ }^{54}$.

U.S. 101 is a limited-access freeway facility through San Luis Obispo, and there are many onand off-ramps to allow access to the city roadway network. The highway enters the city from the north at Monterey Street and exits the city after the Los Osos Valley Road interchange in the south end of the city. According to Caltrans' state highway traffic data, two-way traffic volumes north of the Monterey Street interchange are approximately 40,000 Annual Average Daily Trips (AADT), while two-way volumes south of the Los Osos Valley Road interchange are 62,000 AADT. A majority of this traffic volume can be assumed to be pass-through traffic or traffic connecting points north and south of the city. Although U.S. 101 is operated and maintained by Caltrans, there are segments of the freeway in the middle of the city (i.e., between the Madonna Road and Marsh Street interchanges), where volumes exceed 62,000 AADT. The spike in vehicular volume along this

\footnotetext{
${ }^{53}$ In April 2008, the Airport Area Specific Plan (AASP) and Margarita Area Specific Plan (MASP) were approved for annexation to the City of San Luis Obispo by the San Luis Obispo County Local Agency Formation Commissions (SLO LAFCO). Both planning areas are south of the City's South Hills and proximate to Tank Farm Road. AASP is planned for mostly non-residential uses, while MASP is planned for mostly residential uses (minutes of April 17, 2008 meeting of SLO LAFCO, http://www.slolafco.com/).

${ }^{54}$ The Orcutt Area is located along the southeastern edge of the city limits of San Luis Obispo, an area bounded by Orcutt and Tank Farm roads and the Union Pacific Railroad. The City's Residential Growth Management Ordinance allocates 1,000 residential dwellings to the Orcutt Area for phased development between 2008 and 2019. (http://www.slocity.org/communitydevelopment/oasp.asp and City of San Luis Obispo Municipal Code Chapter 17.88: Residential Growth Management Regulations).
} 
stretch of freeway may indicate that to some extent, there is some use of U.S. 101 by local traffic in order to bypass downtown traffic or to connect from the north end of town to the Madonna shopping area (or vice versa), as a matter of convenience. At this time no standard emission reporting protocol exists that provides definitive direction as to how to quantify vehicle mileage that occurs in a given community. For that reason, all vehicle mileage from the Los Osos Valley Road exit to the Monterey Street exit was counted in the community-wide emissions inventory.

Within the city limits, SR-1 (Santa Rosa Street) and SR-227 (Madonna Road, South Street, and Broad Street) are primarily utilized as major arterials, and are classified as such by the City's Circulation Element. Although operated and maintained by Caltrans, the segments of these roadways within the city limits largely serve local traffic.

U.S. 101 highway on- and off-ramps are included in the community-wide VMT figures. Although these facilities are operated and maintained by Caltrans, the use of the on- and off-ramps indicates that a vehicle is about to enter or exit the local roadway network.

For the purposes of analysis of vehicle-miles of travel resulting from the traffic count data, the city was split into eight subareas. The numerous traffic count segments were aggregated into these subareas by using the traffic analysis zones utilized in the city-maintained traffic demand model. A map showing the location of the VMT subareas and denoting the roadways for which traffic counts are collected is included in section 4.4 of this document.

\subsubsection{Solid Waste sector}

The solid waste sector calculates emissions for the decomposition of waste under a specified disposal method (in this case, managed landfill). There are two methods for calculating greenhouse 
gas emissions in the waste sector - methane commitment method and the waste-in-place method. The methane commitment method, which was used in this inventory, quantifies the net lifetime greenhouse gas emissions from waste disposed of in the active year. This method attributes all future emissions to the year in which the waste was produced.

The San Luis Garbage Company provides waste disposal services for residents and businesses in San Luis Obispo. The San Luis Garbage service area extends beyond city limits to include residential properties and commercial businesses adjacent to the city.

San Luis Garbage indicated that approximately 92 percent of residential customers lived within the city limits. The company provided waste tonnage for both residential and commercial customers (without specifying whether waste was generated by a city or county customer). Therefore, it was assumed that 92 percent of both residential and commercial waste was generated by customers located in the community. Waste tonnage data is available for years 2005, 2006 and 2007.

The CACP software uses a waste composition of the following categories: paper products, food waste, plant debris, wood/textiles, and all other waste. Available data did not fall precisely into each of the above categories. However, the Utilities Department maintains data that tracks waste tonnage attributable to residences and businesses in San Luis Obispo. This data is disaggregated into many categories of solid waste, including commercial haulers, cardboard, white goods (appliances), and green waste, among others. With the assistance of Utilities Department staff, the categories of solid waste were assigned into the aforementioned five categories. This was done in order to reasonably represent waste composition generated by the community before entering data into the software to calculate estimated emissions. 


\subsubsection{Air Travel}

The San Luis Obispo County Regional Airport (McChesney Field) is located just outside the southeast limits of the city. Three airlines provide commercial air service at the airport. The airport is operated by the County, which precludes the City of San Luis Obispo from having any operational control of the airport for purposes of the municipal emissions inventory.

However, it is understood that residents and businesses of San Luis Obispo rely on the airport for commercial air service. According to Caltrans' Office of Aviation Planning, in 1995 there were 267,335 total passengers at McChesney Field. In 2006 there were 354,998 total passengers, a 33 percent increase in passenger service. It is not known what percentage of those passengers are San Luis Obispo residents.

Emissions from air travel are calculated in a way similar to vehicle-miles of travel. A primary determinant of the level of emissions is the transport fuel used in the vehicle or airplane. The Local Government Operations Protocol lists two emission factors for use in the calculation of greenhouse gas emissions ${ }^{55}$.

However, the Protocol does not have a standard practice that allows for the calculation of emissions generated by air travel to be attributed to an individual community. Emissions from community air travel are more difficult to calculate and reasonably attribute to an individual community than other mobile sources (i.e., vehicles), as aircraft spend a limited amount of time in a given community, let alone an air basin. A study of aircraft source emissions was completed by the San Luis Obispo County Air Pollution Control District (APCD) in August 2008, which considered

\footnotetext{
55 The emission factor for Aviation Gasoline is $8.32 \mathrm{~kg} \mathrm{CO}_{2}$ per gallon, the emission factor for Jet Fuel (Jet A or A-1) is $9.57 \mathrm{~kg} \mathrm{CO}_{2}$ per gallon. These emission factors are found in Appendix G (Table G.9) of the Protocol.
} 
aircraft emissions at the three commercial and general aviation airports in the county - San Luis Obispo County Regional Airport, Oceano County Airport, and Paso Robles Municipal Airport. There were 59,033 landings and takeoffs (a total of 118,066 operations) at the San Luis Obispo County Regional Airport during the year 2007.

As no standard protocol exists to calculate emissions from community and regional airports, specific emissions figures are not included in this report. Additionally, an important goal of this emissions inventory is to produce an inventory that is consistent with the methodologies of other inventories across the state.

\subsubsection{Freight and Passenger Train Travel}

The Union Pacific Railroad owns the railroad tracks traveling through the community, and more than a dozen freight trains pass through every day. Additionally, Amtrak provides passenger rail service on both the Coast Starlight (with daily service to Klamath Falls, Oregon) and the Pacific Surfliner (with twice-daily service to Los Angeles) lines. California jurisdictions that have completed emissions inventories to date have not included rail travel, so in order to maintain consistency with other inventories throughout the state, emissions generated from freight and passenger rail travel will not be quantified in this report. Caltrans is working to incorporate freight and passenger train travel in its current climate action planning efforts. As no standard protocol exists to calculate emissions from passenger and freight rail traffic due to the nature of interregional train travel, specific emissions figures are not included in this report. 


\subsection{Municipal inventory data collection methodology}

\subsubsection{Buildings and Facilities sector}

The buildings and facilities sector calculates energy use and emissions associated with city-owned buildings and facilities. This includes leased office space or buildings. The steps used to determine emissions include:

(a) Obtain electricity and natural gas billing records for necessary years (in this case, 2004 through 2007 were available). Records were available in the form of monthly billing records in spreadsheet format.

(b) Extensive data compilation was performed to rearrange and aggregate monthly electricity usage figures to present data as annual electricity usage figures for each building, park, or other facility. Unit of measurement used in monthly bills is kilowatt-hours $(\mathrm{kWh})$.

(c) Facilities such as City Hall, Ludwick Community Center, the four fire stations, parks, and the Corporation Yard were classified as "buildings" in the software.

(d) Natural gas usage figures were available for the following facilities:

- City Hall, 990 Palm Street

- Corporation Yard, 25 Prado Road

- San Luis Obispo County Historical Museum, 696 Monterey Street

- Fire Station \#1, 2160 Santa Barbara Street

- Fire Station \#3, 1284 Laurel Lane

- Jack House, 535 Marsh Street

- Ludwick Community Center, 864 Santa Rosa Street

- SLO Little Theatre/Old City Library, 888 Morro Street

- Parks and Recreation Office, 1341 Nipomo Street

- Police Department, 1042 Walnut Street

- Public Works/Community Development/Parking Garage, 919 Palm Street

- Senior Citizen Center, 1445 Santa Rosa Street 
- Sinsheimer Pool/Swim Center, 900 Southwood

- Water Reclamation Facility, 35 Prado Road ${ }^{56}$

- Utilities Administration, 879 Morro Street

\subsubsection{Vehicle Fleet sector}

The vehicle fleet sector calculates fuel usage and emissions associated with the municipal vehicle fleet. The vehicle fleet information system has the ability to produce reports that, for a given time period, identify vehicle mileage for individual vehicles. Fuel usage figures were collected separately, by reviewing records of all bulk fuel purchases for city vehicles. These records indicate gasoline and diesel purchases split between two separate accounts - Fire Department and general vehicle fleet. However, currently there is no way to link the quantity of fuel purchased with individual vehicles or by vehicle fleet, except for the Fire Department vehicles as a fleet. The vehicle fleet information system does provide vehicle-miles of travel for the following vehicle types and data is entered into the CACP software using these categories:

- Passenger vehicles

- On-road diesel vehicles

- Construction vehicles

- Police vehicles

Transit vehicle fleet information is collected separately. First Transit, the transit operator for the San Luis Obispo Transit system, provides a monthly report to the city's transit manager that includes vehicle mileage for each transit vehicle. Vehicle mileage and fuel usage total were recorded by month and annual totals were calculated. There are 16 transit vehicles in the municipal transit

\footnotetext{
${ }^{56}$ The Water Reclamation Facility is classified as "water \& sewage", whereas all other facilities are classified as "buildings".
} 
fleet. Of these sixteen vehicles, fourteen are transit buses that operate on diesel, while two are trolley vehicles. One trolley operates on diesel, the other operates on gasoline.

\subsubsection{Employee Commute sector}

The employee commute sector calculates fuel usage and emissions associated with travel to and from work by municipal employees. A web-based survey using Survey Monkey was distributed via email, requesting the following information:

(a) Typical weekly work schedule (5 days/week, "9/80" work week, or 3 days/week or less)

(b) Distance traveled to work (one-way)

(c) Primary mode of travel (drive alone, carpool, transit, motorcycle, bike, walk, other)

(d) Secondary mode of travel (if less than 20 percent of all work trips are made using this second mode)

Of the 370 people $^{57}$ employed by the City in the survey year, approximately 250 responses were received, a response rate of 68 percent.

The assumptions utilized in the calculation of vehicle-miles of travel for employee commutes are as follows:

- The work year was assumed to be 50 weeks per year.

- Respondents who selected "5 days/week" work 250 days/year.

- Respondents who selected "9/80" work 225 days/year.

- Respondents who selected " 3 days/week or less" work 150 days/year.

- Respondents who selected "drive alone" as their mode of travel were assigned all vehicle mileage traveled by those trips.

- Respondents who selected "carpool" as their mode of travel were assumed to be traveling with one other person; thus assigned half the vehicle mileage traveled by those trips.

\footnotetext{
${ }^{57}$ This information was provided by April Craft in the Finance Department, and reflects total number of regular fulltime city employees.
} 
- Respondents who selected "motorcycle" as their mode of travel were assigned all motorcycle trips for those trips; mileage would be recorded under motorcycle in the software as opposed to vehicle mileage.

- Respondents who selected "public transit", "bicycle", or "walk" were not assigned vehicle mileage for those trips.

- Secondary mode of travel was assumed to be utilized 20 percent of the time.

The methodology for calculating total vehicle mileage for each individual respondent was as

follows:

(i) Mileage from the primary mode of travel was calculated first, using the following formula:

Number of days worked in a year X One-way distance to work X Assigned percentage from primary mode of travel

(ii) If a secondary mode of travel was reported, the product of equation (i) was multiplied by 0.80 .

(iii) If a secondary mode of travel was reported, mileage from the secondary mode of travel was calculated second, using the following formula:

Number of days worked in a year X One-way distance to work X Assigned percentage from secondary mode of travel

(iv) As the secondary mode of travel was assumed to be utilized 20 percent of the time, the product of equation (iii) was multiplied by 0.20 :

(v) To determine annual total of one-way vehicle mileage from primary and secondary modes of travel, add (i) and (iii).

(vi) To determine annual total of two-way vehicle mileage, multiply (v) by two.

(vii) To determine total vehicle mileage from employee commute for a given year, sum all respondents annual total of two-way vehicle mileage (sum results for all respondents of (vi)).

(viii) Identify all mileage from motorcycle travel separately from vehicle mileage to differentiate data when entering into software. 
A recommendation for subsequent employee commute surveys is to add the following questions to the survey to make data collection more accurate:

(a) "What type of car do you drive?" (light truck, SUV, compact, sedan, hybrid, other)

(b) "What type of fuel do you use?" (gasoline, diesel, electric, other)

\subsubsection{Streetlights and Traffic Signals sector}

The streetlights and traffic signals sector calculates energy consumption and emissions associated with city-owned streetlights and traffic signals. The steps used to determine emissions include:

(a) Obtain electricity billing records for necessary years (in this case, 2004 through 2007 were available). Records were available in the form of monthly billing records in spreadsheet format.

(b) Extensive data compilation was performed to rearrange and aggregate monthly electricity usage figures so as to present data as annual electricity usage figures for each facility. The unit of measurement used in monthly bills is kilowatt-hours $(\mathrm{kWh})$.

(c) The city's 55 traffic signals and city-owned streetlights were classified as "streetlights" in the software.

\subsubsection{Water Delivery sector}

The water delivery sector calculates energy consumption and emissions associated with the municipal water delivery system. The steps used to determine emissions include: 
(a) Obtain electricity billing records for necessary years (in this case, 2004 through 2007 were available). Records were available in the form of monthly billing records in spreadsheet format.

(b) Extensive data compilation was performed to rearrange and aggregate monthly electricity usage figures so as to present data as annual electricity usage figures for each facility. The unit of measurement used in monthly bills is kilowatt-hours $(\mathrm{kWh})$.

(c) Facilities included in the "water delivery" sector include the following:

- Water treatment plant

- 7 water pump stations

- 2 Whale Rock pump stations

- Several water tanks and wells associated with the water delivery system

\subsubsection{Wastewater sector}

The wastewater sector calculates energy consumption and emissions associated with the municipal wastewater system. The steps used to determine emissions include:

(a) Obtain electricity and natural gas billing records for necessary years (in this case, 2004 through 2007 were available). Records were available in the form of monthly billing records in spreadsheet format.

(b) Extensive data compilation was performed to rearrange and aggregate monthly electricity usage figures so as to present data as annual electricity usage figures for each facility. The unit of measurement used in monthly bills is kilowatt-hours (kWh). 
(c) Facilities included in the "wastewater" sector include the following:

- Water reclamation facility

- Effluent structure (northeast of U.S. 101-Los Osos Valley Road interchange)

- 8 sewer lift stations

- Several ancillary facilities associated with wastewater treatment system

\subsubsection{Municipal Solid Waste sector}

The municipal solid waste sector calculates solid waste tonnage and associated methane emissions from municipal operations and facilities. Emissions are based on the quantity of waste hauled to a landfill from municipal operations and the composition of the waste stream. The methane commitment method is used to calculate all future emissions for annual waste generation, which is then applied to the inventory year of 2005. The software uses default categories for the waste composition - paper products, food waste, plant debris, wood/textiles, and all other waste.

The Utilities Department maintains records of the estimated waste tonnage that is generated by each city facility. The San Luis Garbage Company provides service to the city facilities, as it does to city residents and businesses. Three separate bins are available - trash/refuse bins, recycle bins, and green waste bins. Therefore, the records maintained by the city disaggregate overall figures for solid waste into three categories - trash, commingled recycle, and green waste. Staff in the Utilities Department provided insight into how the general composition of refuse by the city facility corresponds with the five categories of waste the CACP software uses for the overall waste composition.

For the purposes of the inventory, recyclables (or "commingled recyclables") were classified as "all other waste". Additionally, green waste was classified as "plant debris". About thirty city facilities generated solid waste. The type of solid waste generated (trash, co-mingled recycled, and green 
waste) by each city facility depends on the nature of the city facility. For example, most of the city offices (including fire stations and community centers) have all three collection bins - refuse, green waste, and recycling; while most of the parks facilities will only have two collection bins - refuse and recycling. Due to data availability, 2007 was used as a proxy year for this particular sector.

\subsubsection{Employee Business Travel sector}

The employee business travel sector calculates emissions associated with employees traveling on for city-related business in private vehicles. These emissions are considered Scope 3 emissions. This includes emissions associated with personal and rented vehicles, mass transit, and air travel. Employee business travel records, or travel reimbursement records, were available for the year 2005 for four departments, while another department had records available for 2008. This was used as a proxy year for 2005. Although not all of the department records explicitly stated whether or not a personal vehicle or city vehicle was used to travel for city-related business, it was determined that approximately twenty percent of employee business travel was in personal or rented vehicles. This percentage was then applied to the departments that did not have sufficient data available. Employee business travel records that indicated a city vehicle was used for the trip were not included in this sector as the mileage would have already been accounted for in the Vehicle Fleet sector.

All vehicle trips were assumed to originate in San Luis Obispo unless otherwise stated. Vehiclemiles of travel were calculated using the driving directions and distance suggested by Google Maps. All air travel was assumed to originate at the San Luis Obispo County Regional Airport. As detailed flight itineraries were not available, air travel distance was calculated using an online air travel trip- 
planning website ${ }^{58}$ to determine an approximate itinerary (i.e., determine all intermediate stops and associated distances) that may have been used to reach the specified destination.

\footnotetext{
${ }^{58}$ www.expedia.com
} 


\section{Chapter 4: COMMUNITY EMISSIONS INVENTORY RESULTS}

\subsection{Community inventory results}

In 2005, the community of San Luis Obispo generated 264,237 metric tons of carbon dioxide equivalent $\left(\mathrm{MTCO}_{2} \mathrm{e}\right)$ emissions. About 50.0 percent of those emissions were produced by the transportation sector. The commercial and industrial sectors combined for 21.9 percent of community emissions, and the residential sector contributed 21.0 percent of community emissions. The solid waste sector accounted for the remaining 7.1 percent of community emissions (see Figure 4.1).

FIGURE 4.1: City of San Luis Obispo greenhouse gas emissions by sector (2005)

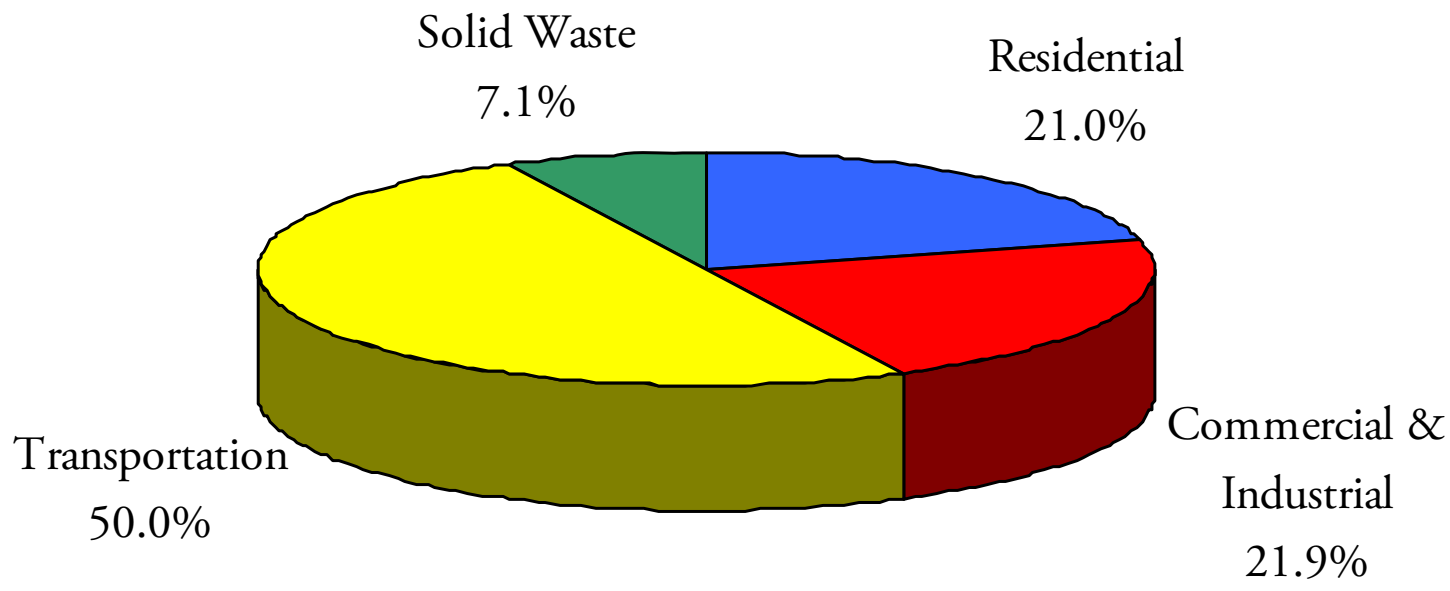

Sources: Pacific Gas \& Electric; Southern California Gas Company; San Luis Garbage; City of San Luis Obispo: Public Works and Utilities departments; Clean Air and Climate Protection software; and Local Government Operations Protocol.

Table 4.1 provides a summary of energy use and greenhouse gas emissions produced by each sector. The number in the last column of the table represents the amount of energy (MMBtu) per amount of greenhouse gas emissions $\left(\mathrm{MTCO}_{2} \mathrm{e}\right)$. This ratio provides an indicator demonstrating the efficiency of each sector in terms of greenhouse gas emissions (a lower number indicates lower 
efficiency). The transportation sector scored the lowest rating primarily because the burning of fossil fuels (especially gasoline and diesel) emits large amounts of $\mathrm{CO}_{2}$ per unit of energy.

TABLE 4.1: Energy consumption and greenhouse gas emissions

\begin{tabular}{|l|r|r|r|r|}
\hline \multicolumn{1}{|c|}{ Sector } & \multicolumn{1}{|c|}{$\begin{array}{c}\text { Energy } \\
\text { (MMBtu) }\end{array}$} & $\begin{array}{c}\text { Equivalent } \mathrm{CO}_{2} \\
\text { (metric tons) }\end{array}$ & $\begin{array}{c}\text { Percent of total } \\
\text { emissions }\end{array}$ & MMBtu / $\mathrm{MTCO}_{2} \mathrm{e}$ \\
\hline Residential & 963,839 & 55,377 & $21.0 \%$ & 17.4 \\
\hline Commercial/Industrial & 961,796 & 57,950 & $21.9 \%$ & 16.6 \\
\hline Transportation & $1,839,962$ & 132,142 & $50.0 \%$ & 13.9 \\
\hline Waste & $\mathrm{n} / \mathrm{a}$ & 18,768 & $7.1 \%$ & $\mathrm{n} / \mathrm{a}$ \\
\hline \multicolumn{1}{|c|}{ Total } & $3,765,597$ & 264,237 & $100.0 \%$ & 14.3 \\
\hline
\end{tabular}

Sources: Clean Air and Climate Protection Software, Local Government Operations Protocol

\subsection{Residential sector}

In 2005, the residential sector generated 55,377 $\mathrm{MTCO}_{2}$ e; representing 21.0 percent of community emissions (see Table 4.2). On average, each household produced roughly $2.9 \mathrm{MTCO}_{2} \mathrm{e}$ from electricity and natural gas. Despite the residential sector having relatively low aggregated per household emissions, residential emissions from electricity usage have increased 11.7 percent from 2003 to 2005 , or nearly 6 percent per year. At the same time, residential emissions from natural gas usage have increased 3.7 percent from 2005 to 2007 , or roughly 2 percent per year.

TABLE 4.2: Residential sector - emissions by fuel type (2005)

\begin{tabular}{|l|r|r|r|r|}
\hline \multicolumn{1}{|c|}{ Fuel type } & $\begin{array}{c}\text { Residential } \\
\text { energy usage }\end{array}$ & $\begin{array}{c}\text { Equivalent } \mathrm{CO}_{2} \\
\text { (metric tons) }\end{array}$ & $\begin{array}{c}\text { Percent of } \\
\text { total emissions }\end{array}$ & $\begin{array}{c}\text { Energy } \\
\text { (MMBtu) }\end{array}$ \\
\hline Electricity & $93,101,466 \mathrm{kWh}$ & 20,820 & $7.9 \%$ & 317,752 \\
\hline Natural Gas & $664,341 \mathrm{Dth}$ & 34,557 & $13.1 \%$ & 646,087 \\
\hline Total & & 55,377 & $21.0 \%$ & 963,839 \\
\hline
\end{tabular}

Sources: Pacific Gas \& Electric, Southern California Gas Company 


\subsection{Commercial and Industrial sectors}

Within this report, the commercial and industrial sectors have been combined due to a mandatory aggregation of commercial and industrial data by $P G \& E^{59}$ and due to limited presence of industrial activity in San Luis Obispo. In 2005, the combined commercial and industrial sectors generated 57,950 $\mathrm{MTCO}_{2} \mathrm{e}$, representing 21.9 percent of the community emissions (see Table 4.3). Emissions from electricity usage have increased 2.8 percent from 2003 to 2005. At the same time, emissions from natural gas usage have increased 7.1 percent from 2005 to 2007.

TABLE 4.3: Commercial and industrial sectors - emissions by fuel type (2005)

\begin{tabular}{|l|r|r|r|r|}
\hline Fuel type & $\begin{array}{c}\text { Commercial \& } \\
\text { Industrial } \\
\text { energy usage }\end{array}$ & $\begin{array}{c}\text { Equivalent } \mathrm{CO}_{2} \\
\text { (metric tons) }\end{array}$ & $\begin{array}{c}\text { Percent of } \\
\text { total emissions }\end{array}$ & \multicolumn{1}{|c|}{$\begin{array}{c}\text { Energy } \\
\text { (MMBtu) }\end{array}$} \\
\hline Electricity & $158,400,882 \mathrm{kWh}$ & 35,423 & $13.4 \%$ & 540,617 \\
\hline Natural Gas & $421,179 \mathrm{Dth}$ & 22,527 & $8.5 \%$ & 421,179 \\
\hline Total & & 57,950 & $21.9 \%$ & 961,796 \\
\hline
\end{tabular}

Source: Pacific Gas \& Electric, Southern California Gas Company

\subsection{Transportation sector}

In 2005, the transportation sector produced $132,137 \mathrm{MTCO}_{2} \mathrm{e}$ emissions, which represents 50.0 percent of community emissions. Emissions from the transportation sector in a given community are directly related to the daily vehicle-miles of travel on city roadways.

The City's Public Works Department maintains a comprehensive and detailed traffic counts program with 176 counting stations, which allows for a detailed analysis of VMT by specific roadway and by area of the city. Table 4.4 provides summary results of the analysis of the 2005-2006 traffic counts program data.

\footnotetext{
${ }^{59}$ The commercial and industrial sectors are combined as a result of the 15/15 rule. The 15/15 rule was adopted by the California Public Utilities Commission in the Direct Access Proceeding (CPUC Decision 97-10-031) to protect customer confidentiality.
} 
TABLE 4.4: Summary of city-wide traffic counts program (2005-2006)

\begin{tabular}{|c|c|c|c|c|c|}
\hline Road type & $\begin{array}{l}\text { Road } \\
\text { miles }\end{array}$ & $\begin{array}{c}\text { Average } \\
\text { daily trips }\end{array}$ & Daily VMT & $\begin{array}{l}\text { Annual } \\
\mathrm{VMT}^{(\mathrm{b})} \\
\text { (in millions) }\end{array}$ & $\begin{array}{c}\text { Equivalent } \mathrm{CO}_{2}{ }^{(\mathrm{c})} \\
\text { (metric tons) }\end{array}$ \\
\hline Collector & 10.20 & 3,925 & 38,348 & 14.0 & 6,492 \\
\hline Minor Arterial & 7.37 & 7,638 & 54,064 & 19.7 & 9,276 \\
\hline Major Arterial & 22.42 & 17,502 & 407,816 & 148.9 & 70,245 \\
\hline County Highway $^{(\mathrm{d})}$ & 1.80 & 13,451 & 15,149 & 5.5 & 2,612 \\
\hline U.S. 101 (Monterey to LOVR) $^{(\mathrm{e})}$ & 4.12 & 55,000 & 236,057 & 86.2 & 40,616 \\
\hline U.S. 101 ramps $^{(f)}$ & 3.89 & 4,108 & 16,806 & 6.1 & 2,896 \\
\hline Total $(\mathrm{g})$ & 49.80 & 20,325 & 768,239 & 280.4 & 132,137 \\
\hline
\end{tabular}

Sources: City of San Luis Obispo, Public Works Department, Transportation Division (City-wide Traffic Counts Program, 2005-06) Notes:

(a) Average of all traffic count segments of each road class (e.g., it could be said that "the average roadway segment of a Collector street has approximately 3,925 vehicle trips per day")

(b) Annual vehicle-miles of travel assume traffic volume is similar 365 days a year.

(c) Due to rounding in the software, this column does not add up.

(d) County Highways are roadways that are not within City Limits, such as Orcutt Road between Johnson Avenue and Tank Farm Road.

(e) U.S. 101 is a Caltrans-maintained limited-access highway within the city limits with significant through-traffic; all vehicle-miles from Monterey exit to Los Osos Valley Road exit were counted in this inventory.

(f) U.S. 101 on- and off-ramps facilities are maintained by Caltrans. However, any traffic volume on ramps from the Los Osos Valley Road interchange to the Monterey Street interchange is assumed to be entering or exiting the local road network in San Luis Obispo. This includes traffic volumes at 32 on- and off-ramps.

(g) The total "Average Daily Trips" is an average value of all average daily trips at all traffic counting stations.

The results of the 2005-2006 traffic counts program suggests that 768,239 daily vehicle-miles of travel (DVMT) occurs within the city limits, including traffic on U.S. 101. Approximately 515,377

DVMT occur on all city roadways. An overwhelming majority of the total mileage on city streets occur on major arterials (407,816 DVMT; 77 percent of all DVMT on city streets) on a given day in the community. These roadways include Santa Rosa Street, Foothill Boulevard, Los Osos Valley Road, Madonna Road, Higuera Street, Marsh Street, (most of) Broad Street, South Higuera Street, Johnson Avenue and Tank Farm Road. The roadway segments that are classified as county highways included in this total that are not within the city limits are Orcutt Road from Johnson Avenue to Tank Farm Road. Total DVMT that occurred on U.S. 101 in 2005 is estimated to be 236,057 miles, while DVMT occurring on U.S. 101 on- and off-ramps is estimated to be 16,806 DVMT. Although these vehicle-miles occur on state-maintained roadways, they are included in this emissions 
inventory. When multiplied by 365 days in a year ${ }^{60}$, annual vehicle-miles of travel are estimated to be 280.4 million vehicle-miles in the community in 2005 . This annual vehicle mileage generates an estimated 132,137 $\mathrm{MTCO}_{2} \mathrm{e}$ emissions.

In 2005, nearly 31 percent of the community's DVMT was attributable to vehicle travel on U.S. 101 between the Los Osos Valley Road and Monterey Street interchanges. The associated emissions $\left(40,616 \mathrm{MTCO}_{2} \mathrm{e}\right)$ accounts for about 15 percent of community emissions. The City does not have jurisdictional control to reduce transportation emissions from "pass-through" vehicle travel through the city limits. However, ICLEI staff recommends that emissions generated by state highway travel be included in a local inventory in order to capture all emissions within the area and calculate their effect in the local community ${ }^{61}$.

No standard protocol exists as to how to calculate annual vehicle-miles of travel (VMT) in a specific community for the purpose of quantifying mobile source emissions for a local emissions inventory. The robust traffic counts data that the city has maintained offers an opportunity to quantify VMT and associated emissions from sample traffic data. This detailed set of data can be analyzed in terms of logical traffic sub-areas. The author suggests eight sub-areas for the purposes of analyzing the results of the VMT calculations, which are shown in Figure 4.2. The VMT sub-areas were created by aggregating several existing city traffic analysis zones to produce larger analysis zones. The map identifies the roadways that were included in the calculation of VMT, the roadways that

\footnotetext{
${ }^{60}$ For the purposes of a identifying emissions generated by transportation at the community level for a greenhouse gas inventory, no standard practice exists at this time to convert DVMT into annual vehicle-miles of travel to account for less travel on weekend days, so 365 days was used to make this conversion. See Chapter 2 (section 2.3.3) for a discussion of how other jurisdictions calculated annual vehicle-miles of travel from daily vehicle-miles of travel in their respective emissions inventories.

${ }^{61}$ Email communication with ICLEI staff, 10 January 2009.
} 
were not included in the calculation of VMT, as well as U.S. 101 and the location of the on- and off-ramps throughout the community.

FIGURE 4.2: Vehicle-miles of travel sub-areas in San Luis Obispo (2005-2006)

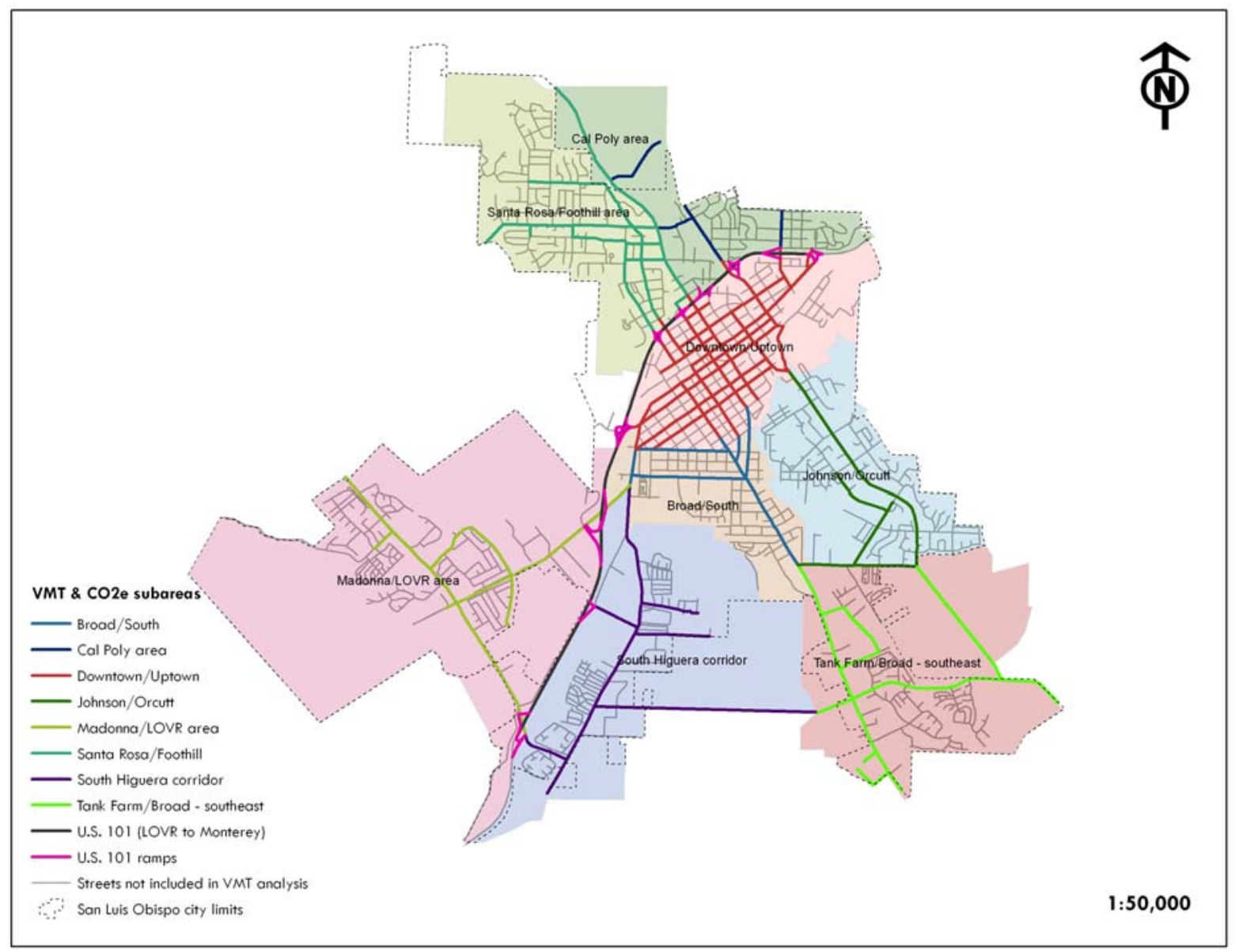

Sources: City of San Luis Obispo Public Works Department, Transportation Division and GIS Division.

When VMT is aggregated at the sub-area level, some sub-areas generated a greater intensity of VMT (in terms of VMT per lane-mile) than others. A detailed analysis of VMT and emissions analysis by VMT sub-area can be found in Appendix $\mathrm{A}^{62}$.

${ }^{62}$ Table A.8 in Appendix A summarizes vehicle-miles of travel and emissions by sub-area; Table A.9 in Appendix A provides an analysis of daily and annual vehicle-miles of travel per lane-mile in each sub-area, as well as emissions per lane-mile in each sub-area. 
Although the city's traffic counts program was the source of data used to calculate VMT on city roadways in 2005, other jurisdictions conducting emissions inventories have used other sources to determine the VMT that occurred in their respective communities ${ }^{63}$. Two annual publications - one state (California Public Road Data) and one federal (Highway Statistics) - were used to determine VMT that occurred on public roads in the communities' inventories reviewed as part of Chapter 2.

The annual California Public Road Data publication is maintained by Caltrans' Division of Transportation System Information. The report contains statistical information that is derived from the federal Highway Performance Monitoring System (HPMS). HPMS is a national level highway information system that includes data on the extent, condition, performance, use, and operating characteristics of the nation's highways, designed and maintained by the Federal Highway Administration (FHWA ${ }^{64}$. This publication includes a data set of maintained mileage and daily vehicle-miles of travel estimates by jurisdiction, as well as daily vehicle-miles of travel estimates on state highways for each county. In this analysis, instead of assigning a portion of the countywide vehicle-miles of travel on state highways to the City of San Luis Obispo, the state highway traffic count data was used to determine the estimated vehicle-miles of travel on state highways through San Luis Obispo. Caltrans' Traffic Data Branch maintains a dataset of annual traffic counts for all

\footnotetext{
${ }^{63}$ See Chapter 2 (section 2.3.3) for a discussion on data sources used by other jurisdictions to determine VMT attributable to their respective communities.

${ }^{64} 2007$ California Public Road Data, California Department of Transportation, Division of Transportation Systems Information, http://www.dot.ca.gov/hq/tsip/hpms/datalibrary.php; Highway Statistics 2007, U.S. Department of Transportation, Federal Highway Administration, Office of Highway Policy Information, http://www.fhwa.dot.gov/policy/ohpi/hss/hsspubs.cfm;
} 
state highways in California ${ }^{65}$. The traffic counts are available for each highway segment; end points of segments are defined by county lines, city limits, or highway interchanges.

The annual Highway Statistics publication is maintained by the Office of Highway Policy Information of the FHWA. This publication is produced using data collected through the HPMS and is a collection of state-maintained datasets. This publication includes a dataset of maintained road mileage and DVMT for urbanized areas with a population of at least 50,000.

Table 4.5 provides a comparison of two sources of historical figures of DVMT reported on public roads in San Luis Obispo. Data is available for both publications (federal and state) from 1996 through 2007. This comparison also shows the total maintained road-miles included in the VMT analysis. This comparison is also shown graphically in Figure 4.3.

Based on the figures from the California Public Road Data in Table 4.5, it is evident that DVMT has increased markedly in San Luis Obispo from 1996 to 2007. Over twelve years, daily vehiclemiles of travel have increased from 584,830 DVMT in 1996 to 745,140 in 2007, an increase of 27 percent. This is an average annual increase of 2.3 percent per year. Overall, DVMT in San Luis Obispo has declined since 2002.

\footnotetext{
${ }^{65}$ California Department of Transportation, Traffic Data Branch, http://traffic-counts.dot.ca.gov/.
} 
TABLE 4.5: Comparison of two sources of historic trends in DVMT in San Luis Obispo (1996-2007)

\begin{tabular}{|c|c|c|c|c|c|c|}
\hline \multirow[b]{3}{*}{ Year } & \multirow{2}{*}{\multicolumn{2}{|c|}{ Maintained road-miles }} & \multicolumn{4}{|c|}{$\begin{array}{l}\text { Daily vehicle-miles of travel (DVMT) } \\
\text { (in thousands) }\end{array}$} \\
\hline & & & \multicolumn{2}{|c|}{$\begin{array}{c}\text { California Public Road Data \& } \\
\text { State Highway Traffic Count Data } \\
\text { (Caltrans) }\end{array}$} & \multicolumn{2}{|c|}{$\begin{array}{c}\text { Highway Performance Monitoring } \\
\text { System } \\
\text { (FHWA) }\end{array}$} \\
\hline & $\begin{array}{c}\text { California } \\
\text { Public Road } \\
\text { Data \& State } \\
\text { Highway Traffic } \\
\text { Count Data }^{(a)} \\
\text { (Caltrans) }\end{array}$ & $\begin{array}{c}\text { Highway } \\
\text { Performance } \\
\text { Monitoring } \\
\text { System } \\
\text { (FHWA) }\end{array}$ & DVMT & $\begin{array}{c}\text { Annual Pct } \\
\text { Change in } \\
\text { VMT } \\
(1996-2007)\end{array}$ & $\mathrm{DVMT}^{(\mathrm{b})}$ & $\begin{array}{c}\text { Annual Pct } \\
\text { Change in } \\
\text { VMT } \\
\text { (1996-2007) }\end{array}$ \\
\hline 1996 & 115.3 & 135.0 & 584.8 & -- & 812.0 & -- \\
\hline 1997 & 115.3 & 135.0 & 620.1 & $6.0 \%$ & 502.0 & $-38.2 \%$ \\
\hline 1998 & 117.3 & 132.0 & 676.7 & $9.1 \%$ & 902.0 & $79.7 \%$ \\
\hline 1999 & 122.0 & 137.0 & 735.4 & $8.7 \%$ & 563.0 & $-37.6 \%$ \\
\hline 2000 & 122.2 & 136.0 & 720.6 & $-2.0 \%$ & 624.0 & $10.8 \%$ \\
\hline 2001 & 122.2 & 136.0 & 741.2 & $2.9 \%$ & 654.0 & $4.8 \%$ \\
\hline 2002 & 124.3 & 137.0 & 797.6 & $7.6 \%$ & 649.0 & $-0.8 \%$ \\
\hline 2003 & 124.6 & 138.0 & 795.7 & $-0.2 \%$ & 676.0 & $4.2 \%$ \\
\hline 2004 & 126.3 & 138.0 & 742.0 & $-6.7 \%$ & 968.0 & $43.2 \%$ \\
\hline 2005 & 126.3 & 147.0 & 752.9 & $1.5 \%$ & $1,007.0$ & $4.0 \%$ \\
\hline 2006 & 126.3 & 209.0 & 738.4 & $-1.9 \%$ & $1,073.0$ & $6.6 \%$ \\
\hline 2007 & 126.3 & 138.0 & 745.1 & $0.9 \%$ & 676.0 & $-37.0 \%$ \\
\hline \multicolumn{4}{|c|}{ Average Annual Percentage Change in VMT (1996-2007) } & $2.3 \%$ & & $-1.4 \%$ \\
\hline
\end{tabular}

Source: “Table 6. Maintained Mileage Data \& Daily Vehicle-Miles of Travel Estimates By Jurisdiction”, California Public Road Data 1996-2007, California Department of Transportation, Division of Transportation System Information, http:/www.dot.ca.gov/hq/tsip/hpms/datalibrary.php;

"Urbanized area summaries: Miles and Daily Vehicle-Miles of Travel", Highway Statistics 1996-2007, Section V: Roadway Extent, Characteristics, and Performance, U.S. Department of Transportation, Federal Highway Administration, Office of Highway Policy Information, http://www.fhwa.dot.gov/policy/ohpi/hss/hsspubs.cfm; and State Highway Traffic Count Data 1996-2007, annual data available at http://traffic-counts.dot.ca.gov/ Notes:

(a) California Public Road Data and State Highway Traffic Count Data is combined for this comparison; VMT on citywide roadways (California Public Road Data) and VMT on U.S. 101 (State Highway Traffic Count Data).

(b) DVMT figures for minor arterials and collectors were not available for Years 1997, 1999, 2000, 2001, 2002, 2003 and 2007 for federal HPMS data. This results in lower DVMT figures for these years.

A comparison of the two datasets in Table 4.5 shows differences in DVMT attributed to San Luis

Obispo from the two different publications. This comparison also suggests the difficulty in selecting

the data source to use to assign DVMT to a given community. The federal publication does not include DVMT figures for minor arterials and collectors for seven of the twelve years between 1996 
and 2007, but does include fifteen to twenty additional maintained road-miles in each year's dataset.

This partial dataset is evident by the un-even trend line shown in Figure 4.3.

\section{FIGURE 4.3: Comparison of two sources of historic trends in DVMT in San Luis Obispo} (1996-2007)

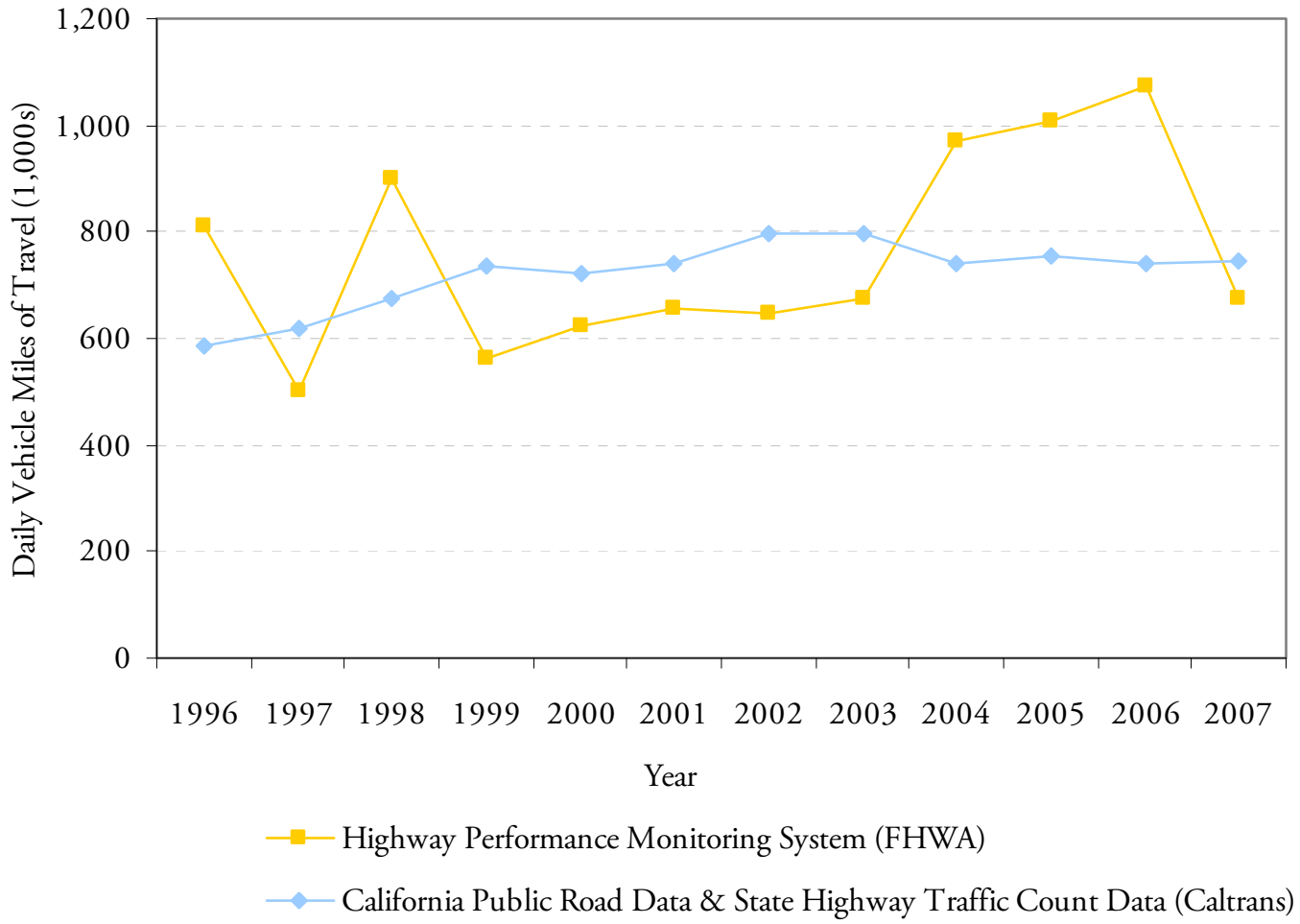

Source: “Table 6. Maintained Mileage Data \& Daily Vehicle-Miles of Travel Estimates By Jurisdiction”, California Public Road Data 1996-2007, California Department of Transportation, Division of Transportation System Information,

http://www.dot.ca.gov/hq/tsip/hpms/datalibrary.php;

"Urbanized area summaries: Miles and Daily Vehicle-Miles of Travel", Highway Statistics 1996-2007, Section V: Roadway Extent, Characteristics, and Performance, U.S. Department of Transportation, Federal Highway Administration, Office of Highway Policy Information, http://www.fhwa.dot.gov/policy/ohpi/hss/hsspubs.cfm; and

State Highway Traffic Count Data 1996-2007, annual data available at http://traffic-counts.dot.ca.gov/

Note:

DVMT figures for Minor Arterials and Collectors were not available for Years 1997, 1999, 2000, 2001, 2002, 2003 and 2007 for federal HPMS data. This results in lower DVMT figures for these years.

Table 4.6 provides a comparison of three sources of data that could be used to determine DVMT on public roadways in San Luis Obispo in 2005. This comparison includes DVMT figures from the federal and state publications as well as the DVMT figures calculated from the city's traffic counts program. The table also provides a comparison of the road-miles included in each data set. 
TABLE 4.6: Comparison of three calculations of DVMT on San Luis Obispo roads (2005)

\begin{tabular}{|c|c|c|c|c|c|c|}
\hline \multirow[b]{2}{*}{ Road type } & \multicolumn{3}{|c|}{ Road-miles included in analysis } & \multicolumn{3}{|c|}{$\begin{array}{l}\text { Daily vehicle-miles of travel (DVMT) } \\
\text { (in thousands) }\end{array}$} \\
\hline & $\begin{array}{c}\text { California } \\
\text { Public Road } \\
\text { Data \& State } \\
\text { Highway } \\
\text { Traffic } \\
\text { Counts }^{(a)} \\
\text { (Caltrans) }^{2} \\
\end{array}$ & $\begin{array}{l}\text { Highway } \\
\text { Statistics } \\
\text { (FHWA) }\end{array}$ & $\begin{array}{l}\text { City's Traffic } \\
\text { Counts } \\
\text { Program }\end{array}$ & $\begin{array}{c}\text { California } \\
\text { Public Road } \\
\text { Data \& State } \\
\text { Highway } \\
\text { Traffic } \\
\text { Counts } \\
\text { (Caltrans) }\end{array}$ & $\begin{array}{l}\text { Highway } \\
\text { Statistics } \\
\text { (FHWA) }\end{array}$ & $\begin{array}{l}\text { City's Traffic } \\
\text { Counts } \\
\text { Program }\end{array}$ \\
\hline Local & -- & 97.00 & -- & -- & 82.00 & -- \\
\hline Collector & -- & 10.00 & 10.20 & -- & 46.00 & 38.35 \\
\hline Minor Arterial & - & 25.00 & 7.37 & -- & 317.00 & 54.06 \\
\hline Major Arterial & -- & 9.00 & 22.42 & -- & 200.00 & 407.82 \\
\hline County Highway & -- & -- & 1.80 & -- & -- & 15.15 \\
\hline Interstate & -- & 0.00 & -- & -- & 0.00 & - \\
\hline $\begin{array}{l}\text { Other Freeways and } \\
\text { Expressways }\end{array}$ & -- & 6.00 & -- & -- & 362.00 & -- \\
\hline City-wide roadways & 121.08 & -- & -- & 443.81 & -- & -- \\
\hline $\begin{array}{l}\text { U.S. } 101 \\
\text { (North City Limits } \\
\text { to South City Limits) }\end{array}$ & 5.26 & -- & 4.12 & 309.05 & -- & 236.06 \\
\hline U.S. 101 ramps & - & - & 3.89 & -- & -- & 16.81 \\
\hline Total miles & 126.34 & 147.00 & 49.80 & 752.86 & $1,007.00$ & 768.24 \\
\hline
\end{tabular}

Source: "Table 6. Maintained Mileage Data \& Daily Vehicle-Miles of Travel Estimates By Jurisdiction”, California Public Road Data 1996-2007, California Department of Transportation, Division of Transportation System Information,

http://www.dot.ca.gov/hq/tsip/hpms/datalibrary.php;

"Urbanized area summaries: Miles and Daily Vehicle-Miles of Travel", Highway Statistics 1996-2007, Section V: Roadway Extent, Characteristics, and Performance, U.S. Department of Transportation, Federal Highway Administration, Office of Highway Policy Information, http://www.fhwa.dot.gov/policy/ohpi/hss/hsspubs.cfm;

State Highway Traffic Count Data 1996-2007, annual data available at http://traffic-counts.dot.ca.gov/; and

City of San Luis Obispo, Public Works Department, Transportation Division (City-wide Traffic Counts Program, 2005-06)

Note:

(a) California Public Road Data and State Highway Traffic Count Data is combined for this comparison; VMT on citywide roadways (California Public Road Data) and VMT on U.S. 101 (State Highway Traffic Count Data).

Table 4.6 highlights the inconsistency in the three data sources in terms of road-miles included in the analysis and the DVMT assigned to San Luis Obispo. Whereas the California Public Road Data publication reports roadways as either "urban" or "rural", the federal Highway Statistics publication disaggregates the road-miles in six different categories. The city's traffic counts program includes daily traffic counts for 176 roadway segments throughout the city, covering about fifty road-miles. 
The other two publications include over 120 road-miles in San Luis Obispo. The difference is shown graphically in Figure 4.4.

FIGURE 4.4: Comparison of road-miles included in three calculations of DVMT in San Luis Obispo (2005)

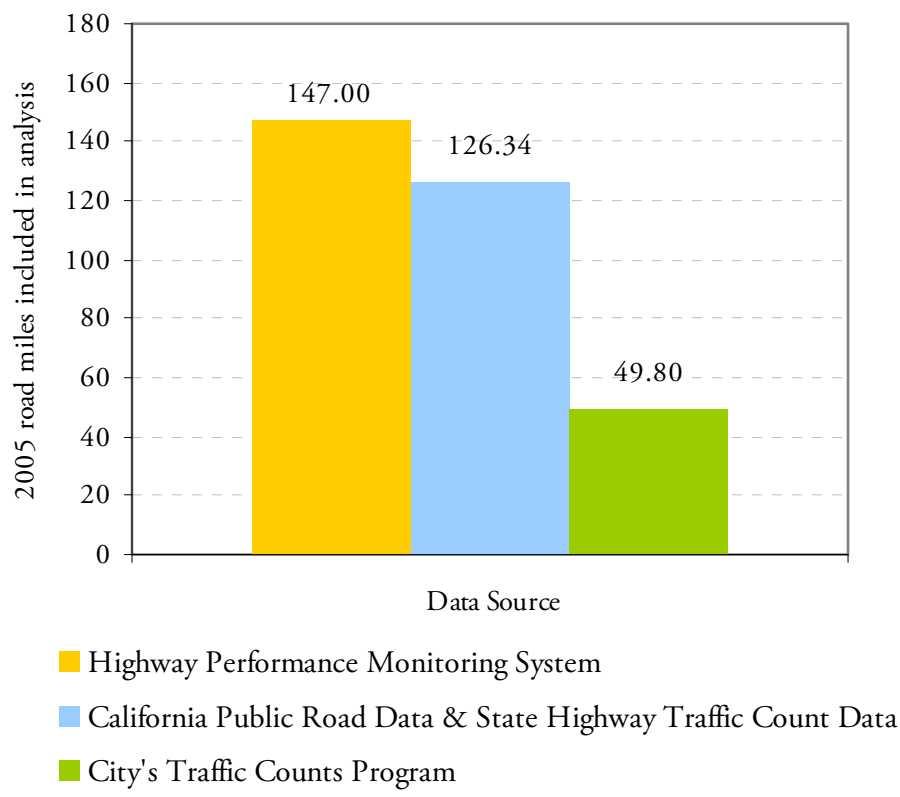

Source: "Table 6. Maintained Mileage Data \& Daily Vehicle-Miles of Travel Estimates By Jurisdiction”, California Public Road Data 1996-2007, California Department of Transportation, Division of Transportation System Information, http:/www.dot.ca.gov/hq/tsip/hpms/datalibrary.php;

"Urbanized area summaries: Miles and Daily Vehicle-Miles of Travel", Highway Statistics 1996-2007, Section V: Roadway Extent, Characteristics, and Performance, U.S. Department of Transportation, Federal Highway Administration, Office of Highway Policy Information, http://www.fhwa.dot.gov/policy/ohpi/hss/hsspubs.cfm;

State Highway Traffic Count Data 1996-2007, annual data available at http://traffic-counts.dot.ca.gov/; and

City of San Luis Obispo, Public Works Department, Transportation Division (City-wide Traffic Counts Program, 2005-06)

The comparison of the three data sources also reveals a noticeable difference in the DVMT in San Luis Obispo between the figures from the federal publication and the other two sources. Although the federal publication disaggregates DVMT by road type, the classifications do not match those assigned by the City of San Luis Obispo. The federal DVMT figures are much higher than the DVMT figures calculated using the city's traffic count data and the combination of the Caltrans' California Public Road Data (VMT on city roadways) and Caltrans' Traffic Data Branch (VMT on state highways). In 2005, the combined state data used to calculate DVMT in San Luis Obispo 
(752,860 daily vehicle-miles of travel) is nearly identical to the DVMT calculated by the city's traffic count data $(768,240$ daily vehicle-miles of travel). The difference between the calculation of DVMT using local, state and federal datasets is shown graphically in Figure 4.5.

FIGURE 4.5: Comparison of three calculations of DVMT in San Luis Obispo (2005)

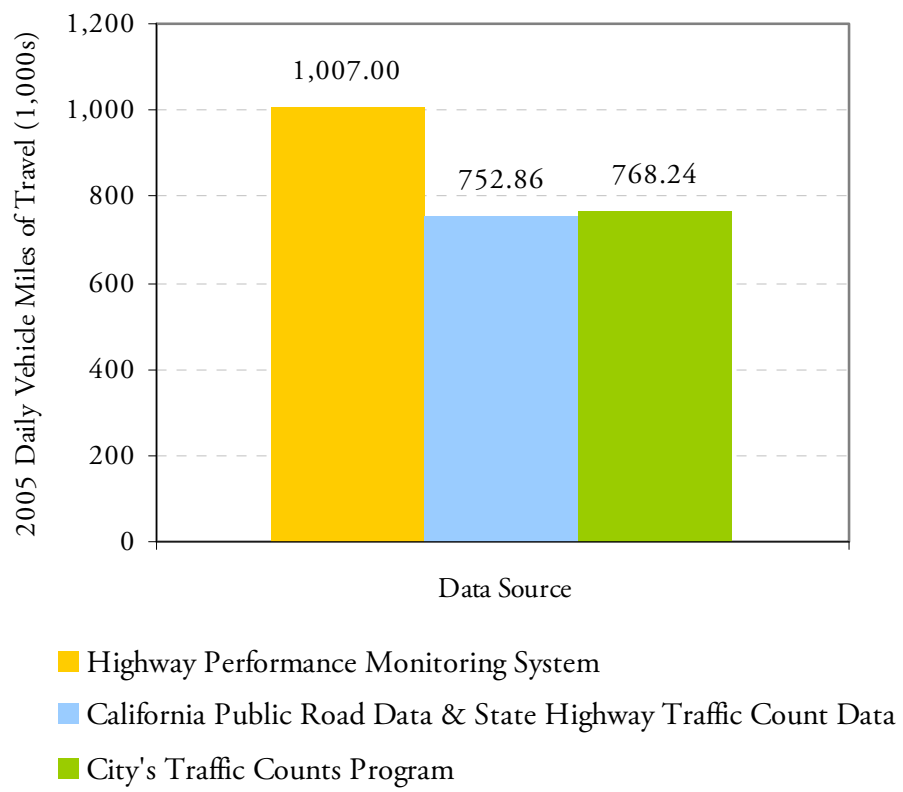

Source: “Table 6. Maintained Mileage Data \& Daily Vehicle-Miles of Travel Estimates By Jurisdiction”, California Public Road Data 1996-2007, California Department of Transportation, Division of Transportation System Information, http:/www.dot.ca.gov/hq/tsip/hpms/datalibrary.php;

"Urbanized area summaries: Miles and Daily Vehicle-Miles of Travel", Highway Statistics 1996-2007, Section V: Roadway Extent, Characteristics, and Performance, U.S. Department of Transportation, Federal Highway Administration, Office of Highway Policy Information, http://www.fhwa.dot.gov/policy/ohpi/hss/hsspubs.cfm;

State Highway Traffic Count Data 1996-2007, annual data available at http://traffic-counts.dot.ca.gov/; and

City of San Luis Obispo, Public Works Department, Transportation Division (City-wide Traffic Counts Program, 2005-06)

Based on the several data sources available to calculate DVMT for a community, it is evident by that some level of ambiguity exists as to how to accurately quantify the vehicle-miles of travel that are attributable to a single community. The nature of mobile emissions from the transportation sector suggests that VMT is best quantified at a regional level. For example, U.S. 101 is the primary transportation facility in San Luis Obispo County and carries a significant volume of traffic between the communities in the county as well as inter-regional travel associated with tourism originating 
outside the county. Again, at this time, no emission reporting protocol is in place to assist in attributing an exact amount of VMT to one community over another. Likewise, there is no standard protocol to attribute a corresponding amount of emissions from the transportation sector to one community over another. For purposes of this inventory, any vehicle travel occurring within the city limits has been counted as part of the community inventory.

\subsection{Solid Waste sector}

In 2005, the community of San Luis Obispo shipped 84,439 tons of waste to the Cold Canyon Landfill. The CACP software calculates methane generation from waste sent to landfills in 2005. The Cold Canyon Landfill maintains a methane recovery factor of 60 percent, which allows the waste sector to produce a net sink in total emissions for the community. The waste sector contributed 18,769 MTCO2e emissions (7.1 percent) to the total community emissions.

The city's Utilities Department tracks historic community-wide solid waste tonnage figures. Table 4.7 shows solid waste tonnage in recent years. All commodities are grouped into two main groups - recycling and trash. Recycling commodities include: newspaper, mixed recyclables, cardboard, aluminum, ferrous metal, glass, plastics, and compostable green waste. Trash includes residential, commercial, commercial haulers, "drop box" (used at construction projects), and trash produced from demolition activities. The 2004 California Statewide Waste Characterization Study ${ }^{66}$ provides standard waste composition for the State of California. Identifying the different types of waste in the general mix is necessary, because decomposition of some materials generate methane within the anaerobic environment of landfills whereas others do not. Carbonaceous materials such as

${ }^{66}$ http://www.ciwmb.ca.gov/Publications/default.asp?pubid=1097 
paper and wood actually act to sequester the methane released in managed landfills, therefore offsetting some or all of the emissions for food and plant waste. Table 4.8 shows the estimated percentages of emissions generated by the various types of waste.

The San Luis Garbage Company ${ }^{67}$ provides waste disposal service to the San Luis Obispo community and transports most waste generated by the community to the Cold Canyon Landfill on Carpenter Canyon Road/SR-227, about six miles south of San Luis Obispo. A limited amount of waste is transported to Southern California, by way of the Santa Maria Transfer Station (located between Nipomo and Santa Maria in San Luis Obispo County, west of U.S. 101).

TABLE 4.7: Solid waste tonnage in San Luis Obispo (2005-2007)

\begin{tabular}{|c|c|c|c|c|}
\hline \multirow{2}{*}{ Commodity group } & \multicolumn{3}{|c|}{ Waste (tons) } & \multirow{2}{*}{$\begin{array}{c}\text { Annual rate of } \\
\text { change } \\
(2005-2007)\end{array}$} \\
\hline & 2005 & 2006 & 2007 & \\
\hline Recycling (paper, aluminum, plastics, greenwaste) & 22,739 & 23,468 & 21,861 & $-1.9 \%$ \\
\hline Trash (residential, commercial, haulers, etc.) & 61,700 & 61,724 & 60,620 & $-0.9 \%$ \\
\hline Total & 84,439 & 85,192 & 82,481 & $-1.2 \%$ \\
\hline
\end{tabular}

Source: City of San Luis Obispo, Utilities Department; San Luis Garbage Company

TABLE 4.8: Solid waste emissions in San Luis Obispo (2005)

\begin{tabular}{|l|r|r|}
\multicolumn{1}{|c|}{ Waste emissions source } & \multicolumn{1}{c|}{$\begin{array}{c}\text { Equivalent } \mathrm{CO}_{2} \\
\text { (metric tons) }{ }^{(\mathrm{a})}\end{array}$} \\
\hline Paper products & 4,772 & $25.4 \%$ \\
\hline Food waste & 11,339 & $60.4 \%$ \\
\hline Plant debris & 1,393 & $7.4 \%$ \\
\hline Wood/textiles & 1,265 & $6.7 \%$ \\
\hline Total & 18,769 & $100.0 \%$ \\
\hline
\end{tabular}

Source: City of San Luis Obispo, Utilities Department; San Luis Garbage Company

Note:

(a) This column may not add up due to rounding in the software.

${ }^{67}$ San Luis Garbage Company is owned by parent-company Waste Connections, Inc. 


\subsection{Community emissions by scope}

The majority of community emissions were Scope 1 (71.6 percent), with Scope 2 emissions (21.3 percent) and Scope 3 (7.1 percent) making up the remaining emissions. Scope 1 emissions include transportation emissions, and those emissions related to fuel combustion, such as natural gas consumption. All Scope 2 emissions are generated by purchased electricity. Scope 3 emissions are those associated with the generation of solid waste (see Table 4.9).

TABLE 4.9: Community emissions by scope (2005)

\begin{tabular}{|l|r|r|r|r|}
\hline \multicolumn{1}{|c|}{ Sector } & \multicolumn{1}{c|}{ Scope 1 } & \multicolumn{1}{c|}{ Scope 2 } & \multicolumn{1}{c|}{ Scope 3 } & \multicolumn{1}{c|}{ Total } \\
\hline Residential & 34,557 & 20,820 & -- & 55,377 \\
\hline Commercial/Industrial & 22,527 & 35,423 & -- & 57,950 \\
\hline Transportation & 132,142 & -- & -- & 132,142 \\
\hline Solid Waste & -- & -- & 18,768 & 18,768 \\
\hline Total & 189,226 & 56,243 & 18,768 & 264,237 \\
\hline Percentage of total CO2e & $71.6 \%$ & $21.3 \%$ & $7.1 \%$ & $100.0 \%$ \\
\hline
\end{tabular}

Sources: Pacific Gas \& Electric; Southern California Gas Company; San Luis Garbage; City of San Luis Obispo: Public Works and

Utilities departments; Clean Air and Climate Protection software; and Local Government Operations Protocol.

\subsection{Source of community emissions}

The largest source of 2005 greenhouse gas emissions generated by the San Luis Obispo community was gasoline, which was the source of 44.6 percent of emissions. Natural gas and electricity accounted for 42.9 percent of community emissions (21.6 and 21.3 percent, respectively). The fourth largest source of emissions was diesel (5.4 percent), followed by paper products ( 4.3 percent), food waste (1.8 percent). The remaining sources of emissions were plant debris and wood and textiles, each accounting for 0.5 percent of emissions. See Figure 4.6. 
FIGURE 4.6: Community emissions by source (2005)

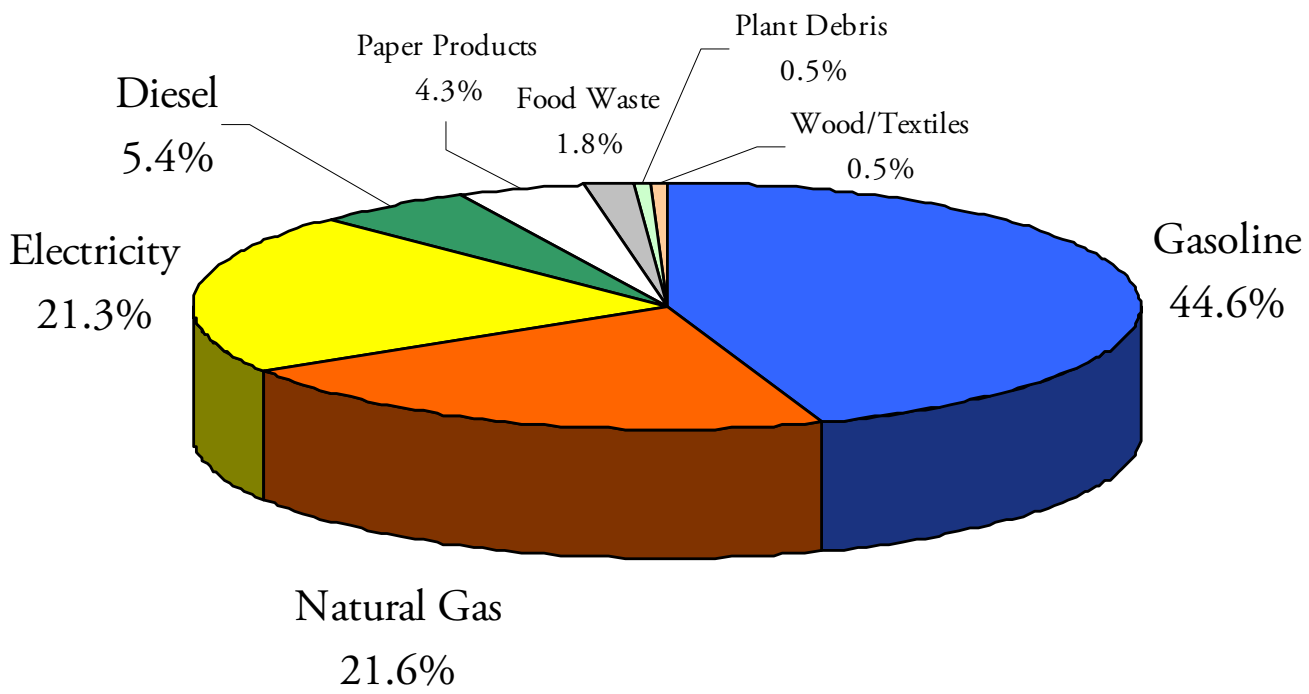

Sources: Pacific Gas \& Electric; Southern California Gas Company; San Luis Garbage; City of San Luis Obispo: Public Works and Utilities departments; Clean Air and Climate Protection software; and Local Government Operations Protocol.

\subsection{Per capita emissions}

As several communities throughout the California are voluntarily conducting greenhouse gas emissions inventory, it is possible to compare the results of this emissions inventory to the results of other jurisdictions in the state. A comparative analysis of per capita emissions can provide decisionmakers and stakeholders with a metric by which to measure the progress made in reducing greenhouse gas emissions. In 2005, San Luis Obispo generated 5.9 $\mathrm{MTCO}_{2}$ e per capita emissions.

Table 4.10 compares the results of this inventory with other communities that have recently completed emissions inventories. San Luis Obispo compares favorably with most of the communities or jurisdictions on this list, especially when compared to the State of California, which generated 13.4 $\mathrm{MTCO}_{2}$ e per capita emissions in 2004 . However, at this time it is impractical to make meaningful comparisons between cities because of the variation in the scope of inventories conducted, data collection methods, and locations of industrial facilities within the state. For 
example, a city that contains a large industrial manufacturing plant within its jurisdictional

boundaries will most likely show a high per capita emissions rate regardless of whether the

community has a great number of persons who bike to work and live in energy efficient houses.

TABLE 4.10: Per capita emissions of selected California jurisdictions

\begin{tabular}{|c|c|c|c|c|}
\hline Jurisdiction & $\begin{array}{c}\text { Baseline } \\
\text { Year of } \\
\text { GHG } \\
\text { Inventory }\end{array}$ & $\begin{array}{l}\text { Metric tons of } \\
\mathrm{CO}_{2} \mathrm{e} \\
\text { (from GHG } \\
\text { Inventory) }\end{array}$ & $\begin{array}{l}\text { Population }^{(a)} \\
\text { (in baseline year of } \\
\text { GHG Inventory) }\end{array}$ & $\begin{array}{l}\mathrm{MTCO}_{2} \mathrm{e} \\
\text { per capita }\end{array}$ \\
\hline City of Arcata & 2000 & 234,703 & 16,651 & 14.1 \\
\hline City of Berkeley & 2005 & 634,798 & 104,010 & 6.1 \\
\hline City of Chico ${ }^{(b)}$ & 2005 & 610,951 & 73,614 & 8.3 \\
\hline City of Davis ${ }^{(c)}$ & 1990 & 225,200 & 46,209 & 4.9 \\
\hline City of Menlo Park & 2005 & 491,054 & 30,558 & 16.1 \\
\hline City of San Luis Obispo & 2005 & 264,237 & 44,625 & 5.9 \\
\hline San Luis Obispo County ${ }^{(\mathrm{d})}$ & 2006 & $1,464,131$ & 101,786 & 14.4 \\
\hline Marin County $^{(\mathrm{e})}$ & 2000 & $3,113,565$ & 247,289 & 12.6 \\
\hline Sonoma County ${ }^{(\mathrm{e})}$ & 2000 & $3,739,380$ & 458,614 & 8.2 \\
\hline State of California ${ }^{(f)}$ & 2004 & $492,000,000$ & $36,675,346$ & 13.4 \\
\hline
\end{tabular}

Source: Greenhouse gas emissions inventories of listed jurisdictions, California Department of Finance, Demographic Research Unit. Notes:

(a) State of California, Department of Finance, E-4 Population Estimates for Cities, Counties and the State, 2001-2008, with 2000

Benchmark. Sacramento, California, May 2008.

(b) City of Chico's Greenhouse Gas \& Criteria Air Pollutant Emissions Inventory bases the community population on the "Greater Chico Area”. This table relies on figures produced by the California Department of Finance. The City of Chico's emissions inventory concludes that per capita emissions in the community are $5.8 \mathrm{MTCO}_{2} \mathrm{e}$ in 2005.

(c) State of California, Department of Finance, E-4 Historical Population Estimates for City, County and the State, 1991-2000, with 1990 and 2000 Census Counts. Sacramento, California, August 2007.

(d) San Luis Obispo County emissions inventory includes only the unincorporated area of the county.

(e) Marin County and Sonoma County emissions inventories include all jurisdictions within each respective county.

(f) California Energy Commission, Inventory of California Greenhouse Gas Emissions and Sinks: 1990 to 2004 (2006), CEC-6002006-013-SF. 


\section{Chapter 5: MUNICIPAL OPERATIONS EMISSIONS INVENTORY RESULTS}

\subsection{Municipal inventory results}

In 2005, the City's municipal operations generated 6,580 $\mathrm{MTCO}_{2} \mathrm{e}$ emissions, and consumed approximately 94,483 MMBtu of energy. The total cost associated with municipal energy and fuel usage in 2005 was $\$ 1.871$ million.

About 96 percent of municipal emissions were produced by the following sectors: vehicle fleet, buildings and facilities, water delivery wastewater, and employee commute sectors (see Table 5.1 and Figure 5.1). The vehicle fleet sector generated 1,898 $\mathrm{MTCO}_{2} \mathrm{e}$ (28.8 percent), the buildings and facilities sector generated 1,178 $\mathrm{MTCO}_{2} \mathrm{e}(17.9$ percent), the wastewater sector generated 1,175 $\mathrm{MTCO}_{2} \mathrm{e}\left(17.9\right.$ percent), the water delivery sector generated $1,043 \mathrm{MTCO}_{2} \mathrm{e}(15.9$ percent), and the employee commute sector generated 1,009 $\mathrm{MTCO}_{2} \mathrm{e}$ (15.3 percent). The remaining three percent of municipal emissions were generated from three other sectors: the municipal solid waste sector generated $125 \mathrm{MTCO}_{2} \mathrm{e}(1.9$ percent), the streetlights and traffic signals sector generated 141 $\mathrm{MTCO}_{2} \mathrm{e}\left(2.1\right.$ percent), and employee business travel sector generated $11 \mathrm{MTCO}_{2} \mathrm{e}(0.2$ percent). 
TABLE 5.1: Municipal operations emissions by sector (2005)

\begin{tabular}{|c|c|c|c|c|}
\hline Sector & Emission scope(s) & $\begin{array}{l}\text { Equivalent } \mathrm{CO}_{2} \\
\text { (metric tons) }\end{array}$ & $\begin{array}{c}\text { Equivalent } \mathrm{CO}_{2} \mathrm{e} \\
(\%)\end{array}$ & $\begin{array}{l}\text { Energy } \\
(\mathrm{MMBtu})\end{array}$ \\
\hline Buildings \& Facilities & Scope $1 \& 2$ & 1,178 & $17.9 \%$ & 19,772 \\
\hline Vehicle Fleet & Scope 1 & 1,898 & $28.8 \%$ & 23,585 \\
\hline Employee Commute & Scope 3 & 1,009 & $15.3 \%$ & 13,418 \\
\hline Streetlights & Scope 2 & 141 & $2.1 \%$ & 2,153 \\
\hline Water Delivery & Scope 2 & 1,043 & $15.9 \%$ & 15,917 \\
\hline Wastewater & Scope $1 \& 2$ & 1,175 & $17.9 \%$ & 18,583 \\
\hline Solid Waste & Scope 3 & 125 & $1.9 \%$ & - \\
\hline $\begin{array}{l}\text { Employee Business Travel } \\
\text { (in private vehicles) }\end{array}$ & Scope 3 & 11 & $0.2 \%$ & 90 \\
\hline Total & & 6,580 & $100.0 \%$ & 93,483 \\
\hline
\end{tabular}

Sources: City of San Luis Obispo: Utilities Department and Public Works Department, 2007 Employee Commute Survey; Pacific Gas \& Electric, Southern California Gas Company

\section{FIGURE 5.1: Municipal operations emissions by sector (2005)}

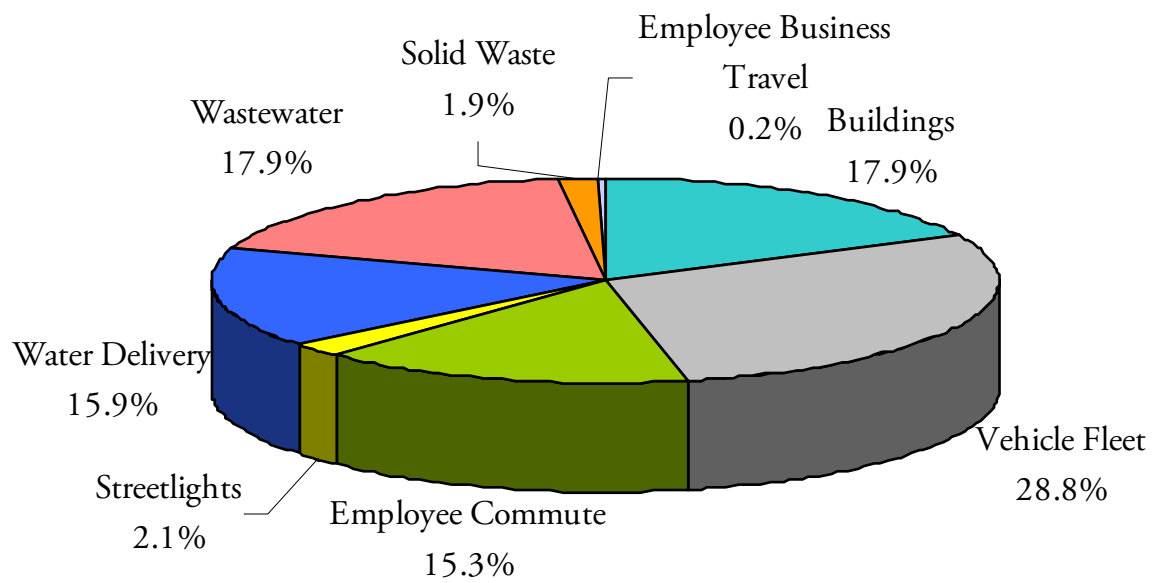

Sources: City of San Luis Obispo: Utilities Department and Public Works Department, 2007 Employee Commute Survey; Clean Air and Climate Protection Software, and Local Government Operations Protocol.

Figure 5.2 shows the City's municipal emissions relative to total community emissions.

Municipal operations generated an estimated 6,580 $\mathrm{MTCO}_{2} \mathrm{e}$ emissions in 2005, which was approximately 2.49 percent of total community emissions. The San Luis Obispo County Communitywide and Municipal 2006 Baseline Greenhouse Gas Emissions Inventory found that a similar percentage $(2.33 \%)$ was determined to be the County government's share of emissions attributable to the unincorporated area of the County. 
FIGURE 5.2: Municipal operations contribution to community emissions (2005)

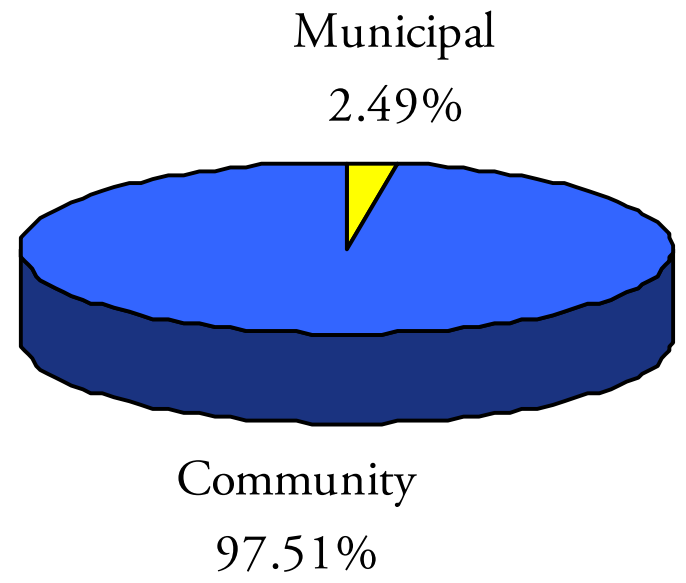

\subsection{Buildings and Facilities sector}

In 2005, the building sector generated 1,178 $\mathrm{MTCO}_{2} \mathrm{e}$ emissions; representing 17.9 percent of total municipal emissions (see Figure 5.1). Emissions generated from this sector originate from purchased electricity and natural gas.

Electricity is primarily used in city buildings for lighting, office equipment and running computer hardware, among other things. In 2005, the City purchased $\$ 365,741$ of electricity for use at buildings and facilities (see Table 5.2). In 2005, the City utilized 109,261 therms of natural gas at various city buildings and facilities, for a total cost of $\$ 112,454$ (see Table 5.3). 
TABLE 5.2: Electricity usage of buildings and facilities and emissions (2005)

\begin{tabular}{|c|c|c|c|c|c|c|}
\hline \multirow[t]{2}{*}{ Buildings and facilities } & \multirow{2}{*}{$\begin{array}{c}\text { Annual } \\
\text { electricity } \\
\text { usage } \\
(\mathrm{kWh})^{(\mathrm{a})}\end{array}$} & \multirow{2}{*}{$\begin{array}{c}\text { Daily } \\
\text { electricity } \\
\text { usage } \\
(\mathrm{kWh})\end{array}$} & \multirow{2}{*}{$\begin{array}{l}\text { Annual } \\
\text { electricity } \\
\text { cost }\end{array}$} & $\begin{array}{c}\text { Equivalent } \\
\mathrm{CO}_{2} \\
\text { (metric tons) }\end{array}$ & \multirow{2}{*}{$\begin{array}{c}\text { Equivalent } \\
\mathrm{CO}_{2} \\
(\%)\end{array}$} & \multirow{2}{*}{$\begin{array}{c}\text { Energy } \\
\text { (MMBtu) }\end{array}$} \\
\hline & & & & $\begin{array}{c}\text { Scope } 2 \\
\text { emissions }\end{array}$ & & \\
\hline Office Buildings & 879,342 & 2,409 & $\$ 110,439$ & 199 & $30.8 \%$ & 3,002 \\
\hline Parking Structures & 444,650 & 1,218 & $\$ \quad 48,089$ & 101 & $15.6 \%$ & 1,518 \\
\hline Swim Center & 391,497 & 1,073 & $\$ 51,035$ & 88 & $13.6 \%$ & 1,336 \\
\hline Parks \& Rec. Facilities & 292,157 & 800 & $\$ \quad 39,367$ & 66 & $10.2 \%$ & 1,007 \\
\hline Corporation Yard & 283,202 & 776 & $\$ 35,513$ & 64 & $9.9 \%$ & 967 \\
\hline Miscellaneous Buildings & 213,810 & 586 & $\$ \quad 29,835$ & 48 & $7.4 \%$ & 740 \\
\hline Fire Stations & 192,351 & 527 & $\$ \quad 27,881$ & 44 & $6.8 \%$ & 726 \\
\hline Cultural/Hist. Facilities & 158,755 & 435 & $\$ 23,443$ & 36 & $5.6 \%$ & 542 \\
\hline All Municipal Facilities & $2,855,764$ & 7,824 & $\$ 365,602$ & 646 & $100.0 \%$ & 9,838 \\
\hline
\end{tabular}

Sources: City of San Luis Obispo, Utilities Department; Pacific Gas \& Electric

Note:

(a) Annual electricity usage data is derived from monthly electricity bills. Naturally, monthly billing cycles of utility bills do not automatically correspond to the monthly calendar, so some overlapping results (i.e., the last week of December 2004 may be included in the January 2005 billing cycle). In all cases, approximately 360 to 365 days are included for each facility's annual electricity usage totals.

TABLE 5.3: Natural gas usage of buildings and facilities and emissions (2005)

\begin{tabular}{|c|c|c|c|c|c|c|}
\hline \multirow[t]{2}{*}{$\begin{array}{l}\text { Buildings and facilities } \\
\text { by type } \mathrm{e}^{(\mathrm{a})}\end{array}$} & \multirow{2}{*}{$\begin{array}{c}\text { Annual } \\
\text { natural } \\
\text { gas } \\
\text { usage }^{(b)} \\
\text { (therms) }\end{array}$} & \multirow{2}{*}{$\begin{array}{c}\text { Daily } \\
\text { natural } \\
\text { gas usage } \\
\text { (therms) }\end{array}$} & \multirow[t]{2}{*}{$\begin{array}{c}\text { Annual } \\
\text { energy cost }\end{array}$} & $\begin{array}{c}\text { Equivalent } \\
\mathrm{CO}_{2} \\
\text { (metric } \\
\text { tons) }\end{array}$ & \multirow{2}{*}{$\begin{array}{c}\text { Equivalent } \\
\mathrm{CO}_{2} \\
(\%)\end{array}$} & \multirow[t]{2}{*}{$\begin{array}{l}\text { Energy } \\
\text { (MMBtu) }\end{array}$} \\
\hline & & & & $\begin{array}{l}\text { Scope } 1 \\
\text { emissions }\end{array}$ & & \\
\hline Swim Center & 58,391 & 160.0 & $\$ 57,226$ & 311 & $58.8 \%$ & 5,839 \\
\hline Office Buildings & 25,535 & 69.9 & $\$ 26,572$ & 136 & $25.7 \%$ & 2,553 \\
\hline Corporation Yard & 7,365 & 20.2 & $\$ 7,759$ & 39 & $7.4 \%$ & 737 \\
\hline Fire Stations & 4,476 & 12.2 & $\$ 5,519$ & 24 & $4.5 \%$ & 448 \\
\hline Cultural/Historical Facilities & 3,065 & 8.3 & $\$ \quad 4,203$ & 16 & $3.0 \%$ & 308 \\
\hline Parks Facilities & 496 & 1.4 & 773 & 3 & $0.6 \%$ & 49 \\
\hline All Buildings \& Facilities & 99,328 & 272.0 & $\$ 102,052$ & 529 & $100.0 \%$ & 9,934 \\
\hline
\end{tabular}

Sources: City of San Luis Obispo, Utilities Department; Southern California Gas Company

Notes:

(a) Not all facilities in Table 5.2 are included in this list as fewer city buildings and facilities use natural gas.

(b) Natural gas usage data is available in monthly records. Therefore, limited data manipulation was required.

In 2007 , city operations at various city buildings and facilities consumed 89.5 gallons of propane, for a total cost of $\$ 314$. In 2008, 139.1 gallons of propane was consumed. These two years are used as a proxy year, as propane usage data was not available for 2005 (see Table 5.4). 
TABLE 5.4: Propane usage of buildings and facilities and emissions (2007 \& 2008)

\begin{tabular}{|c|c|c|c|c|c|c|}
\hline \multirow{2}{*}{$\begin{array}{c}\text { Fuel type } \\
\text { used in } \\
\text { buildings } \\
\text { and facilities }\end{array}$} & $\begin{array}{c}\text { Quantity } \\
\text { (gallons) }\end{array}$ & Fuel price & $\begin{array}{c}\text { Equivalent } \\
\mathrm{CO}_{2} \\
\text { (metric tons) }\end{array}$ & \multirow{2}{|c|}{$\begin{array}{c}\text { Quantity } \\
\text { (gallons) }\end{array}$} & Fuel price & $\begin{array}{c}\text { Equivalent } \\
\mathrm{CO}_{2} \\
\text { (metric tons) }\end{array}$ \\
\cline { 2 - 4 } & & $\begin{array}{c}\text { Scope 1 } \\
\text { emissions }\end{array}$ & & $\begin{array}{c}\text { Scope 1 } \\
\text { emissions }\end{array}$ \\
\hline Propane & 89.5 & $\$ 314$ & $<1$ & 139.1 & $\$ 524$ & 1 \\
\hline
\end{tabular}

Source: City of San Luis Obispo, Finance Department

\subsection{Vehicle Fleet sector}

Detailed records of mileage and fuel were not available for each vehicle in the in the municipal vehicle fleet. The calculation methodology outlined in the Protocol for municipal vehicle fleet, which requires information about each vehicle's mileage and fuel consumption in a given calendar year, was not feasible ${ }^{68}$. However, mileage records were available for four different vehicle groups - passenger vehicles, off-road diesel trucks, construction vehicles and police vehicles. Table 5.5 provides a summary of the municipal vehicle fleet in 2005, not including transit vehicles. The city's police vehicle fleet accounted for the majority of the city's vehicle fleet mileage, with 528,967 miles logged in 2005. Off-road diesel (ORD) trucks logged nearly 75,000 miles in 2005.

TABLE 5.5: Summary of vehicle fleet and mileage (2005)

\begin{tabular}{|l|r|c|r|}
\hline \multicolumn{1}{|c|}{ Vehicle type } & \multicolumn{1}{|c|}{$\begin{array}{c}\text { Number of } \\
\text { vehicles }\end{array}$} & Fuel type & \multicolumn{1}{c|}{$\begin{array}{c}\text { Estimated } \\
\text { vehicle mileage }\end{array}$} \\
\hline Passenger Vehicle & 26 & Gasoline & 30,982 \\
\hline Trucks (Off-Road Diesel) & 15 & Diesel & 74,653 \\
\hline Construction Vehicles & 31 & Diesel & 4,393 \\
\hline Police Vehicles & 58 & Gasoline & 528,967 \\
\hline Transit Vehicle (non-bus) $^{\text {Total }}{ }^{(2)}$ & 3 & Gasoline & 27,727 \\
\hline
\end{tabular}

Source: City of San Luis Obispo, Public Works Department Note:

(a) This total does not include transit vehicles

${ }^{68}$ The calculation methodology is explained in more detail in the Appendix C (C.3 Mobile Combustion) 
The City’s Finance Department maintains financial records for all bulk gasoline and diesel purchases to fuel the city's vehicle fleet. Only account payable invoices covering calendar year 2007 and 2008 were collected. For the purposes of this inventory, 2007 was used as a proxy year for 2005. Based on the total gasoline and diesel purchases in 2007, the city's vehicle fleet (other than the city's transit fleet) generated an estimated 1,145 $\mathrm{MTCO}_{2} \mathrm{e}$ emissions (see Table 5.6). However, since it is not clear what types of vehicles (passenger vehicle, light truck/SUV, or heavy truck) consumed what quantity of either fuel, it is not possible to accurately calculate vehicle emissions from the municipal vehicle fleet based on the methodology described in the Protocol.

TABLE 5.6: Vehicle fleet fuel usage (2007 and 2008)

\begin{tabular}{|c|c|c|c|c|c|c|}
\hline \multirow{3}{*}{ Fuel type } & \multicolumn{3}{|c|}{2007} & \multicolumn{3}{|c|}{2008} \\
\hline & \multirow{2}{*}{$\begin{array}{l}\text { Quantity } \\
\text { (gallons) }\end{array}$} & \multirow[t]{2}{*}{ Fuel price } & $\begin{array}{l}\text { Equivalent } \\
\mathrm{CO}_{2} \\
\text { (metric tons) }\end{array}$ & \multirow{2}{*}{$\begin{array}{l}\text { Quantity } \\
\text { (gallons) }\end{array}$} & \multirow[t]{2}{*}{ Fuel price } & $\begin{array}{l}\text { Equivalent } \\
\mathrm{CO}_{2} \\
\text { (metric tons) }\end{array}$ \\
\hline & & & $\begin{array}{l}\text { Scope } 1 \\
\text { emissions }\end{array}$ & & & $\begin{array}{l}\text { Scope } 1 \\
\text { emissions }\end{array}$ \\
\hline Gasoline & 83,440 & $\$ 238,550$ & 768 & 85,957 & $\$ 291,709$ & 791 \\
\hline Diesel & 35,526 & $\$ 99,589$ & 378 & 39,229 & $\$ 139,176$ & 417 \\
\hline Total & 118,966 & $\$ 338,139$ & 1,145 & 125,186 & $\$ 430,885$ & 1,208 \\
\hline
\end{tabular}

Source: City of San Luis Obispo, Finance Department

In 2005, the city's transit fleet generated $753 \mathrm{MTCO}_{2} \mathrm{e}$ emissions. The annual mileage of city's transit fleet was 401,416 vehicle-miles, while consuming 113,516 gallons of diesel (see Table 5.7). 
TABLE 5.7: Transit vehicle fleet mileage and emissions (2005)

\begin{tabular}{|c|c|c|c|c|}
\hline \multirow{2}{*}{$\begin{array}{l}\text { Vehicle } \\
\text { number }\end{array}$} & \multirow[t]{2}{*}{ Annual mileage } & \multirow{2}{*}{$\begin{array}{l}\text { Diesel } \\
\text { (gallons) }\end{array}$} & \multirow{2}{*}{$\begin{array}{l}\text { Fuel cost per } \\
\text { vehicle } \\
\text { (estimated) }\end{array}$} & $\begin{array}{c}\text { Equivalent } \mathrm{CO}_{2} \\
\text { (metric tons) }\end{array}$ \\
\hline & & & & Scope 1 emissions \\
\hline 128 & 8,835 & 3,210 & 7,899 & 17 \\
\hline 129 & 15,155 & 4,523 & $\$ \quad 11,130$ & 28 \\
\hline 130 & 23,802 & 6,330 & $\$ \quad 15,576$ & 45 \\
\hline 131 & 6,252 & 1,772 & 4,361 & 12 \\
\hline 132 & 29,381 & 8,155 & $\$ \quad 20,068$ & 55 \\
\hline 140 & 21,099 & 8,037 & $\$ \quad 19,777$ & 39 \\
\hline 141 & 18,456 & 7,626 & $\$ \quad 18,766$ & 35 \\
\hline 142 & 0 & 0 & $\$$ & - \\
\hline 143 & 0 & 0 & $\$$ & - \\
\hline 144 & 38,430 & 11,192 & $\$ \quad 27,541$ & 72 \\
\hline 145 & 39,320 & 10,582 & $\$ \quad 26,039$ & 74 \\
\hline 146 & 40,303 & 11,565 & $\$ \quad 28,459$ & 75 \\
\hline 150 & 40,902 & 10,481 & $\$ 25,793$ & 77 \\
\hline 151 & 40,056 & 10,816 & $\$ \quad 26,616$ & 75 \\
\hline 152 & 26,573 & 6,585 & $\$ \quad 16,204$ & 50 \\
\hline 153 & 36,679 & 10,458 & $\$ 25,735$ & 69 \\
\hline Trolley 101 & 15,995 & 2,184 & 5,374 & 30 \\
\hline Trolley 102 & 178 & 0 & $\$$ & $<1$ \\
\hline Total & 401,416 & 113,516 & $\$ 279,338$ & 753 \\
\hline
\end{tabular}

Source: City of San Luis Obispo, Public Works Department (First Transit Monthly Reports, 2005)

The Public Works Department has recently implemented an updated fleet management program.

This new program will allow the department to track mileage and fuel usage for each vehicle on an annual basis, which is information required to accurately calculate mobile emissions from the vehicle fleet.

\subsection{Employee Commute sector}

The City of San Luis Obispo employee commute sector generated 1,009 $\mathrm{MTCO}_{2} \mathrm{e}$ emissions; representing 15.3 percent of total municipal emissions (see Figure 5.1 above). Figure 5.3 provides a graphical distribution of the mode choice of city employees, including their primary and secondary mode choices. An employee’s primary mode choice (e.g., "drive alone" or "bicycle") is assumed to be used eighty percent of the time, while a secondary mode - if used - is assumed to be chosen twenty 
percent of the time. Assumptions used in the employee commute survey are explained in more detail in section 3.10.3. The single-occupant vehicle is the dominant form of transportation, as 67 percent of all respondents choose to drive alone as their primary travel mode. About one-fifth (18 percent) of respondents carpool, 7 percent bicycle, 3 percent walk, and 2 percent use public transit, 2 percent ride a motorcycle, and the other 2 percent use some other form of transportation.

About 70 percent of the respondents have a regular secondary mode of travel to work (approximately 20 percent of the time), which are more evenly distributed among the various modes of travel. "Drive alone" and "carpool" are most frequently used (21 and 20 percent, respectively), while 13 percent of employees choose to bike to work some of the time, and 10 percent of employees choose to take public transit to work some of the time. The other 9 percent ride a motorcycle, walk or use another form of transportation at least some of the time.

The City offers employees (other than those in public safety) a flexible work schedule, where an employee works eighty hours in two weeks, but receives one day off in those two weeks in exchange for working nine-hour days (commonly referred to as "9/80"). About two-thirds of the respondents (64 percent) state that they do participate in this flexible work schedule. Nineteen percent of the respondents work five days a week, and fourteen respondents work three days a week or less. Eight respondents did not answer this question, and were not included in the final calculations. By offering employees the opportunity to have a flexible work schedule, the City is reducing the number of vehicle trips employees are making every year (and subsequently, reducing the amount of vehicle emissions). Employees who work a "9/80" schedule travel to work 25 fewer times in a given 50-week work-year than an employee that works a regular 5-day work week for 50-week work-year. 
FIGURE 5.3: Employee commute mode by primary and secondary mode (2007)

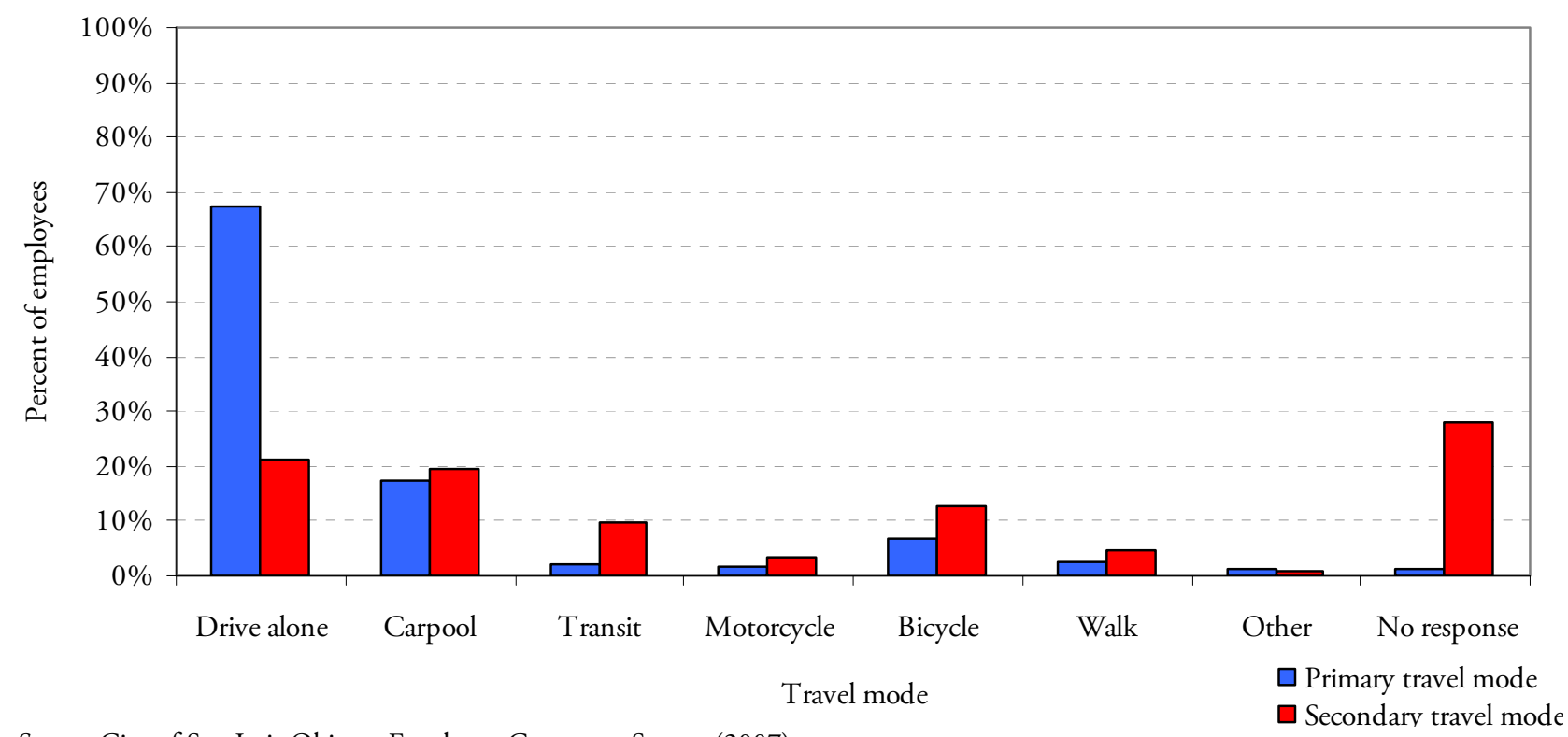

Source: City of San Luis Obispo, Employee Commute Survey (2007)

The average one-way distance traveled to work for respondents to the survey was 13.4 miles.

Figure 5.4 shows the distribution of the respondents' one-way distance to work. Sixty-nine percent of survey respondents live more than five miles from work, which would indicate that they live outside the city limits. A distance greater than five miles means that the employee will not have the option to walk to work, will likely be less inclined to bike to work, and will likely live in an area that is not as well-served by public transit. The other 31 percent of respondents likely live within the city limits, as they live less than five miles from work. They therefore have broader transportation options, with more frequent local public transit service, as well as a bikeable and possibly walkable travel distance to work. 
FIGURE 5.4: Distribution of city employees' distance to work (2007)

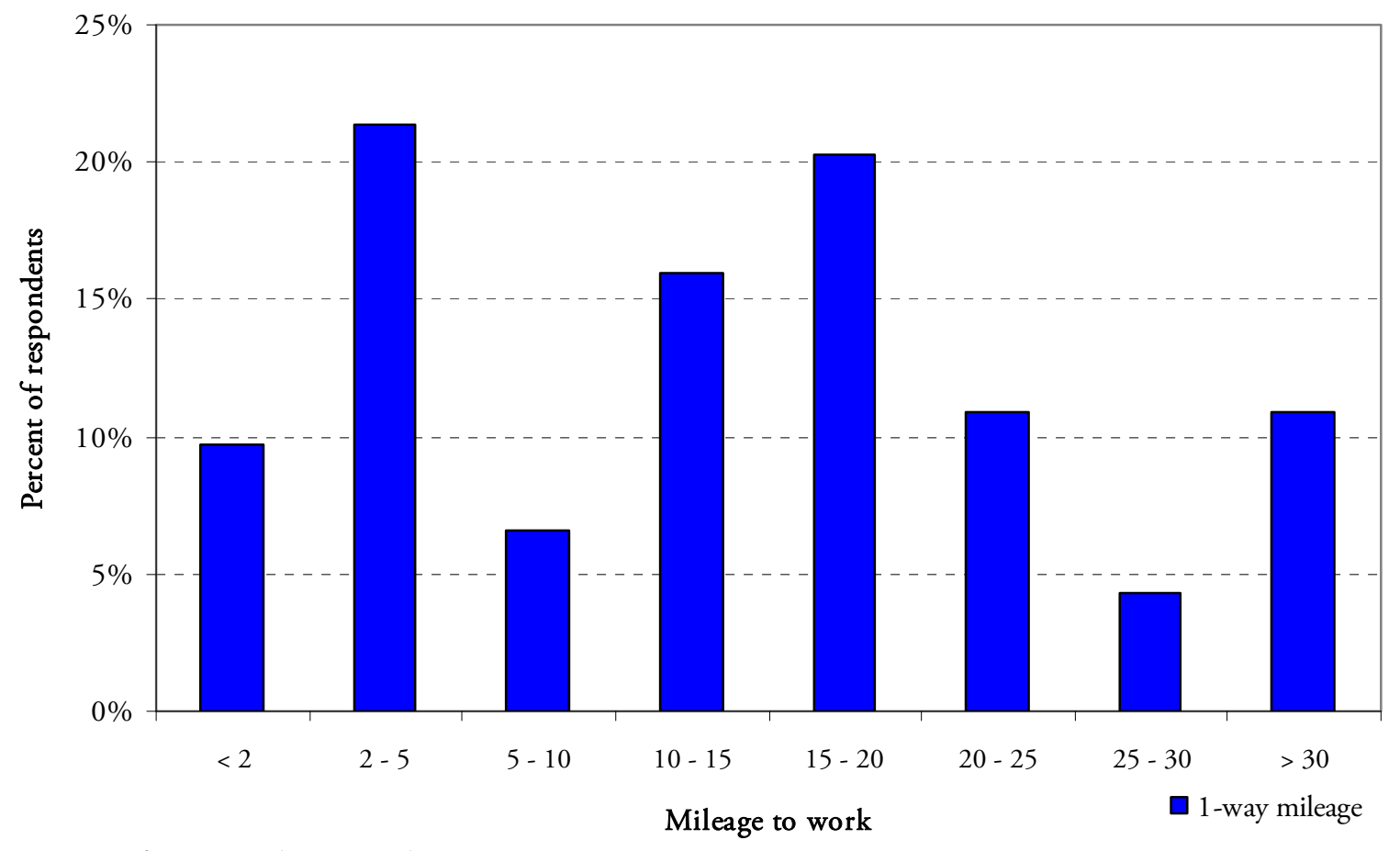

Source: City of San Luis Obispo, Employee Commute Survey (2007)

Table 5.8 provides a summary of the employee commute profile for the city employees that

participated in the survey. The results are displayed in terms of mileage by each mode of

transportation. For the purpose of determining the amount of emissions generated from the

employee commute sector, only mileage from "drive alone", “carpool”, and "motorcycle" mileage

was counted $^{69}$. Therefore, about 1.9 million vehicle-miles -91 percent of the total mileage from the employee commute - were counted toward the emissions total. Vehicle-miles of public transit were not counted, as the bus operates on a scheduled route. No emissions are generated by riding a bike or walking.

69 "Drive alone" and "carpool" mileage was entered into the software as "passenger vehicle", as a more specific distribution of vehicle types was not available. The Clean Air and Climate Protection Software Users' Guide notes that the passenger vehicle type is a composite vehicle category that incorporates all automobile classes (auto - small, medium, and large) as well as light trucks. The survey did not request information about vehicle fuel type, so it was assumed that the eighty percent of employee vehicles operate on gasoline, and twenty percent operate on diesel. "Motorcycle" mileage is entered into a separate category in the software. The software assumes that all motorcycles are fueled by gasoline. 
TABLE 5.8: Summary of employee commute mileage by mode and emissions

\begin{tabular}{|c|c|c|c|}
\hline \multirow{2}{*}{ Employee travel mode } & \multirow{2}{*}{ Annual mileage } & \multirow{2}{*}{$\begin{array}{c}\text { Percent of total } \\
\text { mileage }\end{array}$} & Equivalent $\mathrm{CO}_{2}{ }^{(\mathrm{a})}$ \\
\hline & & & Scope 3 emissions \\
\hline Drive alone & $1,546,162$ & $76.9 \%$ & 826 \\
\hline Carpool $^{(b)}$ & 316,672 & $15.7 \%$ & 169 \\
\hline Transit $^{(\mathrm{c})}$ & 51,928 & $2.6 \%$ & 0 \\
\hline Motorcycle & 39,882 & $2.0 \%$ & 14 \\
\hline Bicycle & 36,089 & $1.8 \%$ & 0 \\
\hline Walk & 3,065 & $0.2 \%$ & 0 \\
\hline Other & 17,900 & $0.9 \%$ & 0 \\
\hline Total & $2,011,698$ & $100.0 \%$ & 1,009 \\
\hline
\end{tabular}

Source: City of San Luis Obispo, Employee Commute Survey (2007)

Notes:

(a) As the survey did not request information about vehicle fuel type, it was assumed that 80 percent of vehicles operate on gasoline, and 20 percent operate on diesel, for the purposes of calculating emissions.

(b) Carpool miles are assumed to be split between two people (i.e., one half-mile is assigned to each the driver and passenger for every vehicle-mile)

(c) Public transit miles are assumed not to be counted toward total employee commute, as no new trip is generated.

San Luis Obispo offers several viable transportation alternatives to the single-occupant vehicle, as its compact size makes it a very walkable and bikeable town. The city also is able to operate an efficient transit system to serve residents and businesses. Because of these reasons, city employees (and residents) have several transportation options to move around within the city limits and, as shown above, do choose to use several modes of transportation in order to get to work. It is then possible to quantify (or estimate) the total emissions that are averted because employees do use other forms of transportation other than the single-occupant vehicle. Table 5.9 shows the amount of $\mathrm{CO}_{2-}$ equivalent emissions that are averted because some employees are carpooling, taking public transit, biking or walking to work.

As an example, city employees logged a total of nearly 52,000 miles on the local and regional public transit system in 2007. Public transit trips are already scheduled to operate based on a given transit schedule whether an employee chose to take the bus or not. If the employee instead chose to drive alone in a vehicle (perhaps assuming there was no public transit system in operation), then 
those 52,000 miles in a passenger vehicle would have generated $32 \mathrm{MTCO}_{2} \mathrm{e}$ of additional emissions.

The calculations in Table 5.9 also assume that if all the city employees that had carpooled had

instead elected to drive alone, the nearly 194,000 vehicle-miles driven by carpoolers would have

doubled to nearly 388,000 vehicle-miles, which translates into $119 \mathrm{MTCO}_{2} \mathrm{e}$ of additional

emissions. The total single-occupant vehicle mileage averted due to commute patterns of city

employees is 309,471 miles; $180 \mathrm{MTCO}_{2} \mathrm{e}$ emissions are averted.

TABLE 5.9: Employee commute mileage and emissions averted (2007)

\begin{tabular}{|c|c|c|c|c|c|c|}
\hline $\begin{array}{l}\text { Employee travel } \\
\text { mode }\end{array}$ & $\begin{array}{c}\text { Annual } \\
\text { mileage } \\
\text { (survey } \\
\text { respondents) }\end{array}$ & $\begin{array}{l}\text { Mileage if } \\
\text { employee } \\
\text { were to } \\
\text { drive alone }\end{array}$ & $\begin{array}{l}\text { Single- } \\
\text { occupant } \\
\text { vehicle } \\
\text { mileage } \\
\text { averted }\end{array}$ & $\begin{array}{l}\text { Emissions } \\
\text { based on } \\
\text { survey } \\
\text { results }\end{array}$ & $\begin{array}{l}\text { Emissions if } \\
\text { employee } \\
\text { were to } \\
\text { drive alone }\end{array}$ & $\begin{array}{l}\text { Emissions } \\
\text { averted }\end{array}$ \\
\hline Carpool & 193,961 & 387,922 & 193,961 & 119 & 238 & 119 \\
\hline Transit & 51,928 & 51,928 & 51,928 & 0 & 32 & 32 \\
\hline Motorcycle & 39,882 & 39,882 & 39,882 & 10 & 15 & 5 \\
\hline Bicycle & 36,089 & 36,089 & 36,089 & 0 & 22 & 22 \\
\hline Walk & 3,065 & 3,065 & 3,065 & 0 & 2 & 2 \\
\hline Total (selected modes) & 324,925 & 518,886 & 324,925 & 129 & 309 & 180 \\
\hline
\end{tabular}

Source: City of San Luis Obispo, Employee Survey (2007)

\subsection{Streetlights and Traffic Signals sector}

In 2005, the streetlights sector generated $141 \mathrm{MTCO}_{2} \mathrm{e}$ emissions; representing 2.1 percent of total municipal emissions (see Figure 5.1). Emissions generated from this sector originate from purchased electricity used to illuminate roadway lights, traffic control signal lights, and city park lighting.

In 2005, the City purchased 628,574 kilowatt-hours of electricity for the operation of streetlights and traffic signals throughout the community, at a cost of $\$ 147,518$. Table 5.10 shows the distribution of electricity usage between streetlights and traffic signals. 
TABLE 5.10: Streetlights and traffic signals electricity usage and emissions (2005)

\begin{tabular}{|c|c|c|c|c|c|c|}
\hline \multirow{2}{*}{$\begin{array}{l}\text { Streetlights and } \\
\text { traffic signals }\end{array}$} & \multirow{2}{*}{$\begin{array}{l}\text { Annual } \\
\text { electricity } \\
\text { usage } \\
(\mathrm{kWh})\end{array}$} & \multirow{2}{*}{$\begin{array}{c}\text { Daily } \\
\text { electricity } \\
\text { usage } \\
(\mathrm{kWh})\end{array}$} & \multirow{2}{*}{$\begin{array}{l}\text { Annual } \\
\text { electricity } \\
\text { cost }\end{array}$} & \multirow{2}{*}{$\begin{array}{c}\text { Daily } \\
\text { electricity } \\
\text { cost }\end{array}$} & $\begin{array}{c}\text { Equivalent } \\
\mathrm{CO}_{2} \\
\text { (metric tons) }\end{array}$ & \multirow{2}{*}{$\begin{array}{l}\text { Energy } \\
(\text { MMBTU) })^{1}\end{array}$} \\
\hline & & & & & $\begin{array}{l}\text { Scope } 2 \\
\text { emissions }\end{array}$ & \\
\hline $\begin{array}{l}\text { City-owned } \\
\text { streetlights }\end{array}$ & 415,536 & $1,138.5$ & $\$ 114,340$ & $\$ 313.26$ & 93 & 1,419 \\
\hline $\begin{array}{l}\text { PG\&E-owned } \\
\text { streetlights }\end{array}$ & 93 & 0.25 & no data & no data & 0 & 7 \\
\hline $\begin{array}{l}\text { Johnson Avenue } \\
\text { underpass lighting }\end{array}$ & 1,876 & 5.1 & 403 & $\$ \quad 1.11$ & $<1$ & 6 \\
\hline $\begin{array}{l}\text { City-wide traffic } \\
\text { signals }\end{array}$ & 211,069 & 578.3 & $\$ 32,775$ & $\$ 89.79$ & 47 & 721 \\
\hline $\begin{array}{r}\text { All streetlights \& } \\
\text { traffic signals }\end{array}$ & 628,574 & $1,722.2$ & $\$ 147,518$ & $\$ 404.16$ & 141 & 2,153 \\
\hline
\end{tabular}

Source: City of San Luis Obispo: Utilities Department; Pacific Gas \& Electric

Conventional traffic lighting systems use incandescent bulbs for traffic signals, which typically require 135 watts of power. In the 1990s, light-emitting diodes (LED) lighting technology was developed, which use semiconductor technology to convert excess energy into light; typical power requirements range from 10 to 22 watts per signal color (red, amber, or green) ${ }^{70}$. An economic feasibility study by the Traffic Engineering Division of the City of Little Rock, Arkansas, found that LED signals consume about 90 percent less energy than conventional signals with incandescent bulbs $^{71}$. By 2000, the City of San Luis Obispo had installed LED lights for all red and green traffic control signal lights at the city's traffic signals.

\subsection{Water Delivery sector}

In 2005, the water delivery sector generated 1,043 $\mathrm{MTCO}_{2} \mathrm{e}$ emissions; representing 15.9 percent of municipal emissions (see Figure 5.1). Emissions generated from this sector originate from

\footnotetext{
${ }^{70}$ Lighting Research Center, "Summary of LED and Traffic Signal Technology". (http://lrc.rpi.edu/programs/transportation/LED/LEDTrafficSignal.asp)

${ }^{71}$ City of Little Rock, Department of Public Works, Traffic Engineering Divisions, "Conventional vs. LED traffic signals: operational characteristics and economic feasibility" (2003). (http://www.cee1.org/gov/led/little_rock.pdf)
} 
purchased electricity used to deliver water from the Whale Rock Reservoir in Cayucos to the city's water treatment plant, operate the water treatment plant, and distribute water by way of the water pumping stations throughout the community ${ }^{72}$. Over half ( 52 percent) of the emissions generated by the water delivery sector are attributable to the energy needed to deliver water 17.6 miles from Whale Rock Reservoir to the water treatment plant ${ }^{73}$.

In 2005, the City purchased 4.67 million kilowatt-hours of electricity for the operation of the water delivery system, at an estimated cost of $\$ 487,275$. Table 5.11 shows the distribution of electricity usage throughout the water delivery system.

The City of San Luis Obispo fulfills its local water demand from two sources of surface water Whale Rock Reservoir and Salinas Reservoir (Santa Margarita Lake) - and ground water. The Salinas Dam was originally built in 1941 to supply water to Camp San Luis Obispo and, secondarily, to meet the water needs of the City. In 1947, the Salinas Dam and delivery system was transferred from the regular Army to the U.S. Army Corps of Engineers. Since 1965, the San Luis Obispo County Flood Control and Water Conservation District has operated this water system for the City under a lease from the U.S. Army Corps of Engineers ${ }^{74}$. Water from the reservoir is

\footnotetext{
${ }^{72}$ Not all water delivered from the Whale Rock Reservoir in Cayucos is delivered to the City of San Luis Obispo. Water from Whale Rock Reservoir is also delivered to Cal Poly, California Men's Colony, and Dairy Creek Golf Course. In 2005, approximately $84.6 \%$ of the water delivered to the City of San Luis Obispo. About $14.5 \%$ of the Whale Rock Reservoir water was delivered to Cal Poly; the balance was delivered to California Men's Colony and Dairy Creek Golf Course $(0.5 \%$ and $0.4 \%$, respectively).

${ }^{73}$ City of San Luis Obispo website, water supply sources: http://www.slocity.org/utilities/sources.asp.

${ }^{74}$ Although the U.S. Army Corps of Engineers owns the Salinas Dam and its associated facilities, it has a formal agreement that provides full operational and financial control to the County of San Luis Obispo. The County manages the facility for recreational use and water supply. At present, the City of San Luis Obispo is the only user of the facility for drinking water. The County manages a water pump station adjacent to northbound U.S. 101 on the north side of the Cuesta Grade. By way of the formal agreement, the City reimburses the County for cost of the operation of the U.S. 101 pump station and other costs related to provision of drinking water to the City. However, any improvements to the
} 
pumped through the Cuesta Tunnel (a one-mile long tunnel through the mountains of the Cuesta

Ridge) and then flows by gravity to the City's Water Treatment Plant on Stenner Creek Road. The

City has water rights to store up to 45,000 acre-feet.

The City has developed a water recycling program in an effort to supplement the city's existing

and future water supply. The city's water reclamation facility produces tertiary recycled water

suitable for most uses other than swimming and drinking. This recycled water source may reduce the

need for the City to identify additional water sources in the future; this would also forego the need

to develop additional water delivery systems in the future that requires a significant amount of

energy to pump water through the pipelines from distant water sources, thus reducing Scope 2

emissions from purchased electricity.

facility must be authorized and directed by the County Board of Supervisors. County Public Works staff indicated that any improvements or other issues at the facility are reviewed and determined through collaboration between City and County staff and generally paid for by the City (personal communication with Mark Hutchinson, County of San Luis Obispo Public Works Department, provided by Tammy Seale, June 18, 2009). After discussions between City and County staff, consultant staff, and ICLEI staff, it was determined that the emissions associated with the operation of the U.S. 101 pump station shall be included in the County's baseline emissions inventory for 2006. In 2006, electricity usage at the U.S. 101 pump station generated 139 metric tons of carbon dioxide equivalents (County of San Luis Obispo Community-Wide and County Government Operations Baseline Greenhouse Gas Emissions Inventory, April 2009, page 43 of detailed report for Government Greenhouse Gas Emissions).

However, it is important to point out that the City of San Luis Obispo holds significant operational and financial control over the quantity of electricity used at the U.S. 101 pump station. As city Utilities Department staff indicated, the City needs to evaluate where and in what quantity to pull water from its two surface water supply sources (Salinas and Whale Rock reservoirs). As a result, the quantity of water that is taken from Salinas Reservoir will fluctuate from year to year, and sometimes wildly. In 2005 and 2006, for instance, significantly more water was taken from Whale Rock Reservoir than from Salinas Reservoir; far less water was taken from Salinas Reservoir than in normal years, which translated into less electricity used at the U.S. pump station for those years (personal communication with Gary Henderson, City of San Luis Obispo Utilities Department, on June 19, 2009). Therefore, it is important to keep in mind that although emissions associated with the U.S. 101 pump station are included in the County's baseline emissions inventory, in future emissions inventory analyses, the amount of emissions associated with this pump station may vary significantly due in large part to operational decisions made by another governmental entity. 
TABLE 5.11: Water delivery electricity usage and emissions (2005)

\begin{tabular}{|c|c|c|c|c|c|c|}
\hline \multirow{2}{*}{$\begin{array}{l}\text { Water delivery system } \\
\text { facilities }\end{array}$} & \multirow{2}{*}{$\begin{array}{l}\text { Annual } \\
\text { electricity } \\
\text { usage } \\
\text { (kWh) }\end{array}$} & \multirow{2}{*}{$\begin{array}{l}\text { Daily } \\
\text { electricity } \\
\text { usage } \\
\text { (kWh) }\end{array}$} & \multirow{2}{*}{$\begin{array}{l}\text { Annual } \\
\text { electricity } \\
\text { cost }\end{array}$} & \multirow{2}{*}{$\begin{array}{c}\text { Daily } \\
\text { electricity } \\
\text { cost }\end{array}$} & $\begin{array}{c}\text { Equivalent } \\
\mathrm{CO}_{2} \\
\text { (metric tons) }\end{array}$ & \multirow{2}{*}{$\begin{array}{l}\text { Energy } \\
\text { (MMBtu) }\end{array}$} \\
\hline & & & & & $\begin{array}{c}\text { Scope } 2 \\
\text { emissions }\end{array}$ & \\
\hline Whale Rock pump stations $s^{(a)}$ & $2,411,225$ & 6,606 & $\$ 242,881$ & $\$ \quad 665.43$ & 539 & 8,230 \\
\hline Water treatment plant & $1,260,042$ & 3,452 & $\$ 127,990$ & $\$ 350.66$ & 282 & 4,300 \\
\hline Miscellaneous & 813,498 & 2,229 & $\$ 89,179$ & $\$ 244.33$ & 182 & 2,776 \\
\hline Water pump stations & 178,543 & 489 & $\$ 27,143$ & 74.36 & 40 & 609 \\
\hline Water tanks & 427 & 1.2 & 367 & 1.01 & 0.1 & 4 \\
\hline All water delivery facilities & $4,663,735$ & $12,777.2$ & $\$ 487,562$ & $\$ 1,335.78$ & 1,043 & 15,919 \\
\hline
\end{tabular}

Sources: City of San Luis Obispo: Utilities Department; Pacific Gas \& Electric

Note:

(a) The total electricity used by Whale Rock Pump Station reflects the share of water delivered to San Luis Obispo. See footnote 28.

\subsection{Wastewater sector}

In 2005, the wastewater sector generated $1,185 \mathrm{MTCO}_{2}$ e emissions; representing 18.1 percent of municipal emissions (see Figure 5.1). Emissions generated from this sector originate from purchased electricity used to provide power to deliver sewage from residences and businesses through the city's sewerage system by way of the sewer lift stations to the water reclamation facility, located along U.S. 101 between Prado Road and Los Osos Valley Road. Nearly all (over 97 percent) of the emissions originating from the wastewater sector were generated from the water reclamation facility. This is primarily due to the energy-intensive process of wastewater treatment. Eighty-four percent of emissions generated in the wastewater sector originated from purchased electricity. The remaining 16 percent originated from the combustion of natural gas used to heat digesters and other operations.

In 2005 , the City purchased 4.44 million kilowatt-hours of electricity for the operation of the wastewater system, at a cost of $\$ 490,579$. Table 5.12 shows the distribution of electricity 
consumption through the wastewater system. In the same year, the City utilized 34,279 therms of natural gas at the water reclamation facility, for a total cost of $\$ 34,143$ (see Table 5.13).

TABLE 5.12: Wastewater electricity usage and emissions (2005)

\begin{tabular}{|c|c|c|c|c|c|c|}
\hline \multirow{2}{*}{$\begin{array}{l}\text { Wastewater delivery system } \\
\text { facilities }\end{array}$} & \multirow{2}{*}{$\begin{array}{l}\text { Annual } \\
\text { electricity } \\
\text { usage } \\
(\mathrm{kWh})\end{array}$} & \multirow{2}{*}{$\begin{array}{l}\text { Daily } \\
\text { electricity } \\
\text { usage } \\
(\mathrm{kWh})\end{array}$} & \multirow{2}{*}{$\begin{array}{l}\text { Annual } \\
\text { electricity } \\
\text { cost }\end{array}$} & \multirow{2}{*}{$\begin{array}{c}\text { Daily } \\
\text { electricity } \\
\text { cost }\end{array}$} & $\begin{array}{l}\text { Equivalent } \\
\mathrm{CO}_{2} \\
\text { (metric tons) }\end{array}$ & \multirow{2}{*}{$\begin{array}{l}\text { Energy } \\
\text { (MMBtu) }\end{array}$} \\
\hline & & & & & $\begin{array}{l}\text { Scope } 2 \\
\text { emissions }\end{array}$ & \\
\hline Sewer lift stations & 134,505 & 368.6 & $\$ 18,645$ & $\$ \quad 51.08$ & 30 & 458 \\
\hline Water reclamation facility & $4,302,311$ & $11,787.2$ & $\$ 471,934$ & $\$ 1,292.97$ & 962 & 14,697 \\
\hline All wastewater delivery facilities & $4,440,674$ & $12,155.8$ & $\$ 490,579$ & $\$ 1,344.05$ & 993 & 15,155 \\
\hline
\end{tabular}

Source: City of San Luis Obispo: Utilities Department; Pacific Gas \& Electric

TABLE 5.13: Wastewater natural gas usage and emissions (2005)

\begin{tabular}{|l|c|c|c|c|c|c|}
\hline $\begin{array}{c}\text { Wastewater delivery system } \\
\text { facility }\end{array}$ & $\begin{array}{c}\text { Annual } \\
\text { natural gas } \\
\text { usage } \\
\text { (therms) }\end{array}$ & $\begin{array}{c}\text { Daily } \\
\text { natural gas } \\
\text { usage } \\
\text { (therms) }\end{array}$ & $\begin{array}{c}\text { Total } \\
\text { natural gas } \\
\text { cost }\end{array}$ & $\begin{array}{c}\text { Daily } \\
\text { natural gas } \\
\text { cost }\end{array}$ & $\begin{array}{c}\text { Equivalent } \\
\mathrm{CO}_{2} \\
\text { (metric } \\
\text { tons) }\end{array}$ & $\begin{array}{c}\text { Energy } \\
\text { (MMBT) }\end{array}$ \\
\cline { 1 - 1 } & $\begin{array}{c}\text { Scope } 1 \\
\text { emissions }\end{array}$ & \\
\hline Water reclamation facility & 34,279 & 93.9 & $\$ 34,143$ & $\$ 93.54$ & 182 & 3,428 \\
\hline
\end{tabular}

Source: City of San Luis Obispo: Utilities Department; Southern California Gas Company

\subsection{Municipal Solid Waste sector}

Municipal operations generated 276 tons of solid waste, which generated $125 \mathrm{MTCO}_{2} \mathrm{e}$ emissions. This represents 1.9 percent of the total municipal emissions. Paper products represent about half (49 percent) of the total waste and generates $41 \mathrm{MTCO}_{2} \mathrm{e}$ emissions (33 percent of municipal waste emissions). Food waste represents 44 percent of total waste and generates 80 $\mathrm{MTCO}_{2} \mathrm{e}$ emissions (64 percent of municipal waste emissions). Plant debris and wood and textiles represent a small amount of the total waste (7 percent combined), and generates $4 \mathrm{MTCO}_{2} \mathrm{e}$ emissions (3 percent of municipal waste emissions). See Table 5.14.

The Clean Air and Climate Protection software distributes the waste tonnage of "all other waste" between "paper products" and "food waste" based on the existing distribution of waste. Therefore, 
the approximately 62 tons of "all other waste" is split between "paper products" and "food waste" in the following manner: 32.8 tons to "paper products" and 29.7 tons to "food waste". Therefore, a total of 135.5 tons (instead of 102.7 tons) of waste is considered paper products, and 122.7 tons (instead of 93.0 tons) of waste is considered food waste.

TABLE 5.14: Solid waste tonnage and emissions (2007)

\begin{tabular}{|c|c|c|c|c|}
\hline \multirow[t]{2}{*}{ Waste type } & \multirow[t]{2}{*}{ Annual tonnage } & \multirow{2}{*}{$\begin{array}{l}\text { Percent of } \\
\text { total waste }\end{array}$} & $\begin{array}{c}\text { Equivalent } \mathrm{CO}_{2} \\
\text { (metric tons) }\end{array}$ & \multirow{2}{*}{$\begin{array}{l}\text { Percent of total } \\
\text { waste emissions }\end{array}$} \\
\hline & & & Scope 3 emissions & \\
\hline Paper products & 135.5 & $49 \%$ & 41 & $32.8 \%$ \\
\hline Food waste & 122.7 & $44 \%$ & 80 & $64.0 \%$ \\
\hline Plant debris & 7.6 & $3 \%$ & 2 & $1.6 \%$ \\
\hline Wood/textiles & 10.3 & $4 \%$ & 2 & $1.6 \%$ \\
\hline Total & 276.1 & $100 \%$ & 125 & $100.0 \%$ \\
\hline
\end{tabular}

Source: City of San Luis Obispo: Utilities Department

\subsection{Other sectors - employee business travel}

A limited amount of greenhouse gas emissions may be attributable to employee business travel in personal vehicles. Of the five departments from which data was received, it was determined that 12,803 miles were driven in personal vehicles to attend various city-related business, while employee air travel to attend various conferences totaled 18,316 miles. The vehicle mileage generated 5.76 $\mathrm{MTCO}_{2} \mathrm{e}$ emissions, while the air mileage generated 4.9 $\mathrm{MTCO}_{2} \mathrm{e}$ emissions. Mileage in city vehicles was already counted as Scope 1 emissions in the vehicle fleet sector, and therefore was not doublecounted here (see Table 5.15). 
TABLE 5.15: Employee business travel mileage and emissions (2005)

\begin{tabular}{|c|c|c|c|c|c|}
\hline \multirow[t]{2}{*}{ City department } & \multirow{2}{*}{$\begin{array}{l}\text { Mileage } \\
\text { from city } \\
\text { vehicles } \\
\text { (counted as } \\
\text { Scope } 1 \\
\text { emissions) }\end{array}$} & \multirow{2}{*}{$\begin{array}{l}\text { Mileage from } \\
\text { personal } \\
\text { vehicles } \\
\text { (counted as } \\
\text { Scope } 3 \\
\text { emissions) }\end{array}$} & \multirow{2}{*}{$\begin{array}{l}\text { Mileage from } \\
\text { air travel } \\
\text { (counted as } \\
\text { Scope } 3 \\
\text { emissions) }\end{array}$} & $\begin{array}{c}\text { Equivalent } \\
\mathrm{CO}_{2} \text { from } \\
\text { vehicle travel } \\
\text { (metric tons) }\end{array}$ & $\begin{array}{c}\text { Equivalent } \mathrm{CO}_{2} \\
\text { from air travel } \\
\text { (metric tons) } \\
\text { (0.59 lbs } \mathrm{CO} 2 \text { per } \\
\text { passenger per mile) }\end{array}$ \\
\hline & & & & $\begin{array}{c}\text { Scope } 3 \\
\text { emissions }\end{array}$ & Scope 3 emissions \\
\hline Community Development & 3,650 & 600 & 4,292 & 0.13 & 1.15 \\
\hline Fire & 5,892 & 1,473 & -- & 0.68 & - \\
\hline Police & 14,936 & 5,790 & 3,958 & 2.67 & 1.06 \\
\hline Public Works & 6,234 & 1,558 & 10,066 & 0.72 & 2.69 \\
\hline Utilities (2008 data) & 14,200 & 3,382 & -- & 1.56 & - \\
\hline Total & 44,912 & 12,803 & 18,316 & 5.76 & 4.90 \\
\hline
\end{tabular}

Source: City of San Luis Obispo departments: Community Development, Fire, Police, Public Works, and Utilities

\subsection{Municipal emissions by scope}

About 44 percent of the emissions generated by the municipal operations of the City of San Luis Obispo were Scope 2 emissions, which includes all purchased electricity. About 41 percent of the emissions generated by municipal operations were Scope 1 emissions, which includes natural gas usage, and the consumption of gasoline and diesel. The other 10 percent were Scope 3 emissions, which include employee commute and employee business travel in private vehicles (see Table 5.16).

TABLE 5.16: Total municipal operations emissions by scope (2005)

\begin{tabular}{|l|r|r|r|r|}
\hline \multicolumn{1}{|c|}{ Sector } & \multicolumn{1}{|c|}{ Scope 1 } & \multicolumn{1}{c|}{ Scope 2 } & \multicolumn{1}{c|}{ Total $^{(\mathrm{a})}$} \\
\hline Buildings & 528 & 650 & -- & 1,178 \\
\hline Vehicle Fleet & 1,898 & -- & -- & 1,898 \\
\hline Employee Commute & -- & -- & 1,009 & 1,009 \\
\hline Streetlights & -- & 141 & -- & 141 \\
\hline Water Delivery & -- & 1,043 & -- & 1,043 \\
\hline Wastewater & 192 & 993 & -- & 1,175 \\
\hline Solid Waste & -- & -- & 125 & 125 \\
\hline Employee Business Travel & -- & -- & 11 & 11 \\
\hline Total by Emission Scope & 2,608 & 2,827 & 1,145 & 6,580 \\
\hline Percentage of total $\mathrm{CO}_{2}$ e emissions & $39.6 \%$ & $43.0 \%$ & $17.4 \%$ & $100.0 \%$ \\
\hline
\end{tabular}

Sources: City of San Luis Obispo: Utilities Department and Public Works Department, 2007 Employee Commute Survey; Clean Air and Climate Protection Software, and Local Government Operations Protocol.

Note:

(a) This column may not add up due to rounding in the software. 


\subsection{Source of municipal emissions}

Emissions generated by the municipal operations originate from five primary sources. Figure 5.5 shows about half of emissions were generated from purchased electricity (43.8 percent), followed by gasoline (24.2 percent), diesel (21.0 percent), and natural gas ( 9.0 percent). Paper products accounted for 1.2 percent of municipal emissions, while food waste, plant debris, and wood and textiles each accounted for less than 1 percent of municipal emissions.

FIGURE 5.5: Municipal operations greenhouse gas emissions by source (2005)

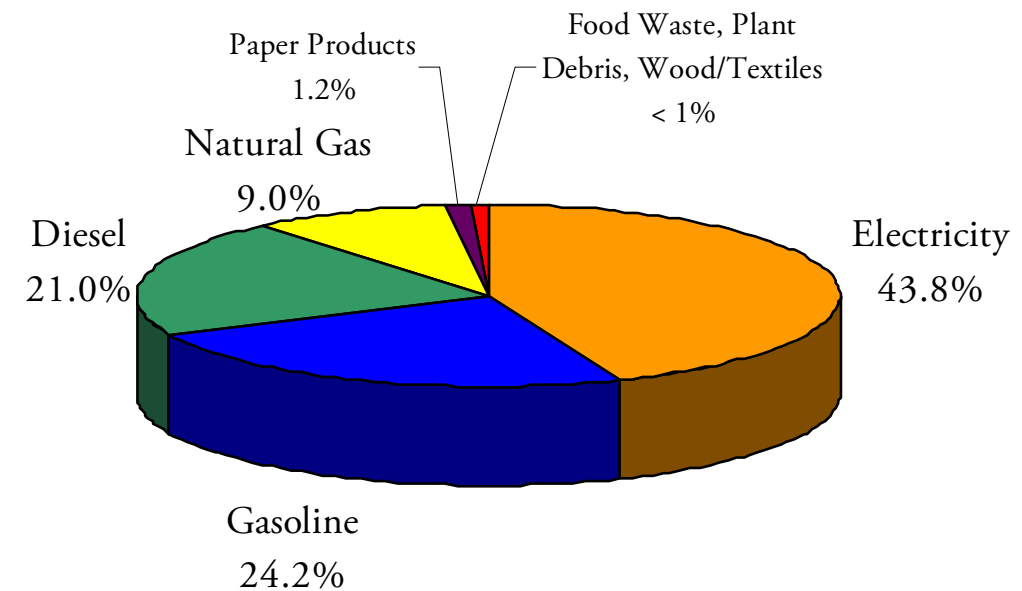

Sources: City of San Luis Obispo: Utilities Department and Public Works Department, 2007 Employee Commute Survey; Clean Air and Climate Protection Software, and Local Government Operations Protocol. 


\section{Chapter 6: FORECAST}

The emissions forecast for the City of San Luis Obispo represents a "business-as-usual" prediction of how community emissions levels could change over time if consumption trends and behavior continue as they did in 2005 . These projections are based on projected growth in population, housing, and employment; projected figures are then derived for gasoline and diesel consumption, electricity and natural gas consumption, and waste tonnage. In 2005, the community produced 264,237 $\mathrm{MTCO}_{2} \mathrm{e}$ emissions. In a "business-as-usual” scenario, community emissions are projected to reach $314,832 \mathrm{MTCO}_{2}$ e emissions by 2020 , or a 19.1 percent increase over baseline levels. See Figure 6.1.

FIGURE 6.1: "Business-as-usual” projection of emissions in San Luis Obispo (2005-2020)

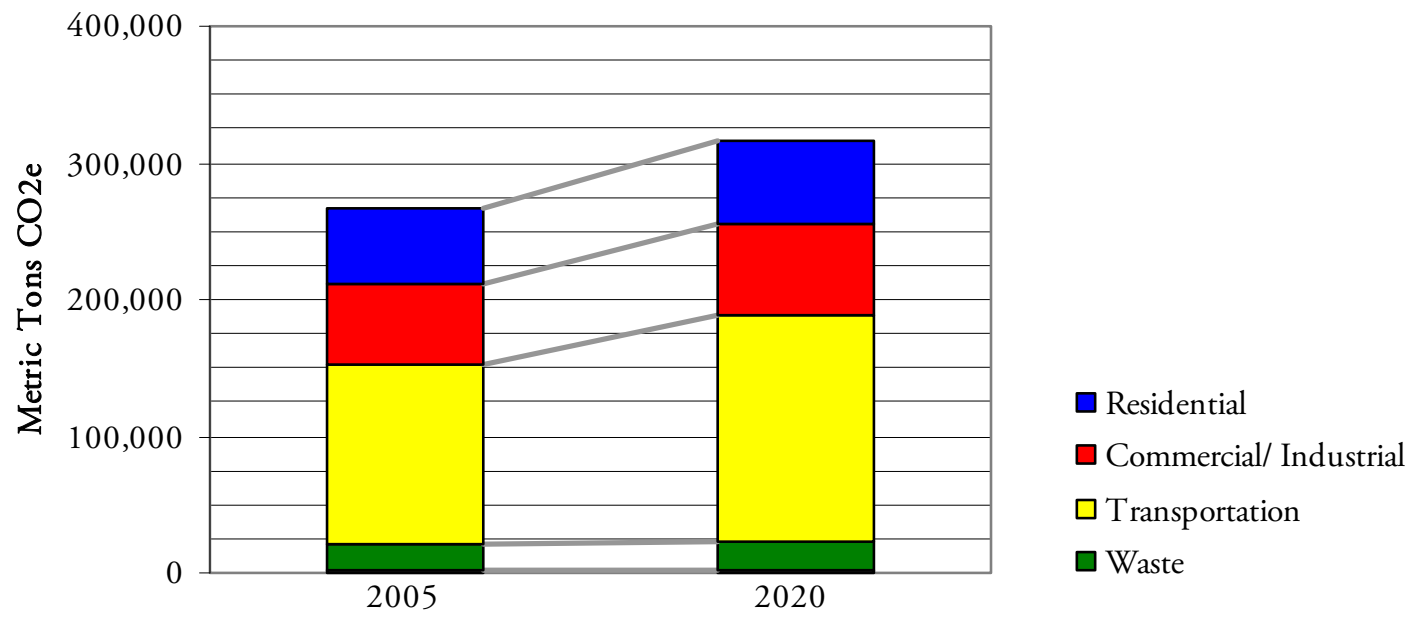

Emissions generated by the transportation sector is expected to rise to $165,416 \mathrm{MTCO}_{2} \mathrm{e}$ emissions by 2020 (a 25.2 percent increase); emissions from the residential sector are expected to increase to 61,579 $\mathrm{MTCO}_{2}$ e emissions by 2020 (an 11.2 percent increase); emissions from the commercial and industrial sectors are expected to increase to 67,551 $\mathrm{MTCO}_{2} \mathrm{e}$ emissions by 2020 (a 
16.6 percent increase); while emissions from the waste sector are expected to increase to 20,286

$\mathrm{MTCO}_{2} \mathrm{e}$ emissions by 2020 (an 8.1 percent increase).

The forecast does not quantify emissions reductions from State or federal activities including AB 32, the renewable portfolio standard, emission reductions achieved from passenger vehicles, lightduty trucks, and non-commercial vehicles under the Pavley bill, and SB 375. Additionally, it does not take into account reduction activities already underway or completed since 2005, the results of which would cause the community emission projection to be below the "business-as-usual" emissions projection.

The 2020 emission forecast was developed by applying the population, household, and employment, and transportation demand growth rates to the 2005 community emissions levels ${ }^{75}$. Estimates for population growth were obtained from a long-range socio-economic projections report developed for the San Luis Obispo region by the San Luis Obispo Council of Governments (SLOCOG) in 2009. The "medium growth" scenario for population and employment growth were used in this forecast estimation ${ }^{76}$. Estimates for household growth were obtained and derived from historic housing occupancy figures provided by Community Development staff ${ }^{7}$.

\footnotetext{
${ }^{75}$ An Excel-based tool was used to develop the 2020 emissions forecast based on population, household, employment, and transportation demand growth rates. The tool applies the compound annual growth rate of population (from 2005 to 2020) to project 2020 waste emissions; the tool applies the compound annual growth rate of households (from 2005 to 2020) to project 2020 residential emissions; the tool applies the compound annual growth rate of employment (from 2005 to 2020) to project 2020 commercial and industrial emissions; the tool applies the compound annual growth rate of statewide vehicle-miles of travel estimates (from 2005 to 2020) to project 2020 transportation emissions.

${ }^{76}$ Projections for population and employment growth for the City of San Luis Obispo were obtained from two SLOCOG reports, Long Range Socio-Economic Projections (Year 2030), prepared by Economic Research Associates for SLOCOG, May 2006; and Update to Long Range Socio-Economic Projections (Year 2035), prepared by Economic Research Associates for SLOCOG, June 2009.

77 Projections for household growth for the City of San Luis Obispo were generated by assuming a reduction of people per household at the rate of 0.01 people per household per year through 2020, then dividing the projected population by
} 
Municipal emissions are not separately analyzed as part of this forecast due to a lack of reasonable growth indicators for municipal services. The City expects that emissions accounted within the scope of the 2005 municipal inventory may decrease due to improved energy efficiency, co-generation at the water reclamation facility, and adding several fuel-efficient vehicles to the municipal fleet. At the same time, it is likely that the City will have to expand services and infrastructure to accommodate the anticipated growth in the community, which could add new sources of emissions to the municipal inventory that did not exist in 2005 .

The City has identified the development of a Climate Action Plan a City goal for fiscal year 2009-10. In addition to identifying areas where efforts will have the most impact, this greenhouse gas emissions inventory will provide the baseline information from which to measure progress.

As the City develops its Climate Action Plan, it will use information in this report to assess which efforts might have the greatest impact in helping the City meet greenhouse gas reduction targets. For example, 50 percent of community emissions are attributed to the transportation sector, based on the amount of vehicle-miles of travel through the community. This includes trips made on local streets as well as trips on U.S. 101 as it passes through San Luis Obispo. Some trips may be related to tourism and pass-through traffic, while some trips are likely related to commuter traffic originating in neighboring communities with a work or shopping destination in San Luis Obispo. 
Some of the ways other communities are addressing transportation emissions include improvements to public transit systems to make using public transportation a more attractive travel mode for commuters. This can include providing shorter headways between buses, increasing the number of routes to serve previously under-served areas, marketing trolley and bus service so that commuters are more familiar with their options, and encouraging employers to provide incentives for employees who use alternative transportation for the journey-to-work commute.

The bulk of municipal emissions are related to energy used by city buildings and energy associated with the municipal vehicle fleet. This information may point to the need to identify ways to make city buildings more energy-efficient and investigate options to invest in alternative fuel vehicles for the municipal fleet in the future.

In its recently approved AB 32 Scoping Plan, CARB encourages local governments to adopt a reduction goal for municipal emissions and to establish similar goals for community emissions that parallel the State's commitment to reduce emissions by approximately 15 percent from current levels by $2020^{78}$. If the City were to conform to this recommended reduction of 15 percent below current levels - to an estimated 224,601 $\mathrm{MTCO}_{2} \mathrm{e}$ emissions - it would require a reduction of 90,231 $\mathrm{MTCO}_{2} \mathrm{e}$ emissions below the community's 2020 "business-as-usual" emission forecast (see Figure 7.1 in Chapter 7), which is equivalent to a 40.2 percent reduction.

\footnotetext{
${ }^{78}$ California Air Resources Board, AB 32 Scoping Plan, December 2008, page 27. In recognition of the importance of local governments in the successful implementation of AB 32, CARB added a section in the Scoping Plan identifying a Local Government Target -- a greenhouse gas emissions reduction target for local government municipal and community-wide emissions of a 15 percent reduction from current levels by 2020 to parallel the State's target. This was noted as a key change from the draft Scoping Plan and the approved Scoping Plan.
} 


\section{Chapter 7: NEXT STEPS AND EXISTING LOCAL ACTIONS}

\subsection{Adopt an emissions reduction target}

The establishment of a community emissions baseline and projection prepares the City to complete the next step - Milestone 2 of ICLEI's Cities for Climate Protection process - by setting an emission reduction target. An emissions reduction target will allow the City to develop a reasonable policy and programmatic response to reduce its contribution to global climate change.

When choosing a reduction target, it is important to keep in mind the following:

1. The State of California has accepted the following reduction targets:

- Reduce statewide emissions to 1990 levels by 2020

- Reduce statewide emissions 80 percent below 1990 levels by 2050

2. Avoid setting a goal that is too distant as it may cause implementation to be delayed.

3. Cities may achieve first-year reductions of emissions as high as 5 percent by pursuing the "low-hanging fruit", while the next 5 percent may take years to achieve.

4. Setting intermittent goals is a good way to monitor progress and stay on track.

Based on the forecast emissions level in 2020, it is possible to estimate the total emissions that need to be reduced to achieve a 15 percent reduction from the 2005 baseline inventory year. Given that the baseline inventory is $264,237 \mathrm{MTCO}_{2} \mathrm{e}$ emissions, San Luis Obispo would have to have an emissions level of 224,601 $\mathrm{MTCO}_{2} \mathrm{e}$ emissions. The estimated actual emissions reduction to achieve a possible 15 percent reduction target would be $90,231 \mathrm{MTCO}_{2} \mathrm{e}$ emissions in 2020, based on the 2020 "business-as-usual" emission forecast of 314,832 $\mathrm{MTCO}_{2} \mathrm{e}$ emissions. This would be a 40.2 
percent reduction in emissions in 2020 assuming no other emission reduction measures are introduced and implemented. Figure 7.1 illustrates this possible reduction scenario.

FIGURE 7.1: Emissions forecast in relation to 15 percent reduction target (2005-2020)

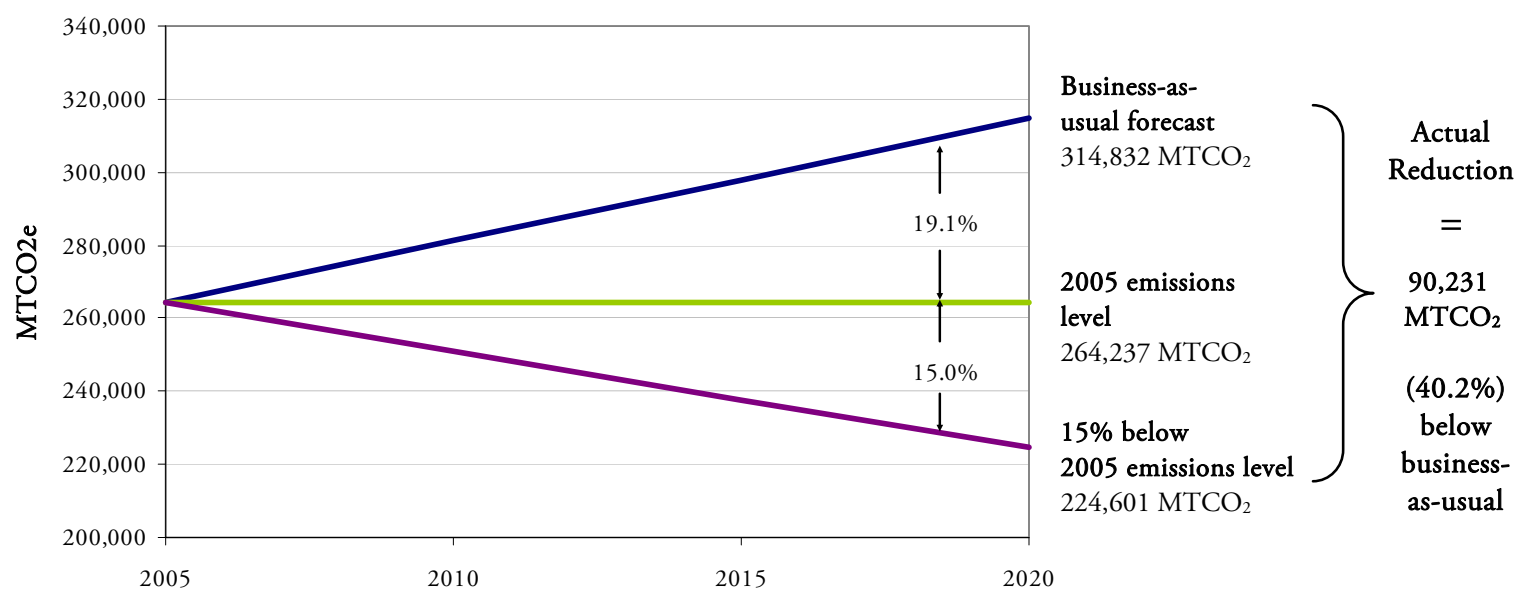

Sources: Pacific Gas \& Electric; Southern California Gas Company; San Luis Garbage; City of San Luis Obispo: Public Works and Utilities departments; Clean Air and Climate Protection software; and Local Government Operations Protocol.

\subsection{Develop a local climate action plan}

After determining an agreed-upon reduction target, the City of San Luis Obispo will develop a climate action plan based on the information revealed in this study - Milestone 3 of ICLEI's Cities for Climate Protection process. Developing a climate action plan will involve multiple steps, such as:

1. Compile a list of existing emission reduction measures already implemented by the City;

2. Quantify emission reductions of existing measures;

3. Evaluate progress relative to the target;

4. Select new emission reduction measures;

5. Quantify emission reductions of new measures; and

6. Develop a comprehensive emission reduction strategy. 
The City should consider the formation of a community task force composed of decision-makers, key city staff, technical experts, and interested members of the public. The task force should consider splitting up tasks in a steering committee and a technical advisory committee. Overall, it is important to encourage strong public involvement and facilitate community buy-in throughout the process of developing the climate action plan.

\subsection{Implementation policies and measures}

The implementation of the policies and measures will not be able to happen all at one time, as is the case with the implementation of many programs. Implementation of the action plan is Milestone 4 of ICLEI's Cities for Climate Protection process. It may be necessary to categorize implementation measures in the following way:

1. "Ready-to-go" actions for existing projects without requiring additional funding;

2. "Ready-to-go" actions that will require new expenditures; and

3. Long-term programs and measures that may require phasing-in or identifying new expenditures.

To the last point in particular, it is important to develop a timeline for implementation of the programs and measures of the climate action plan, while keeping in mind the reduction goal and the target year. The City should strive to maintain strong public involvement to assist in the implementation of the measures and programs of the action plan.

\subsection{Monitor and verify results}

It is important to continue to quantify emissions periodically in order to make sure that implementation measures and programs are achieving the desired results. For example, as existing 
and proposed measures are implemented, appropriate data can be collected and entered into the Clean Air Climate Protection software to verify that emissions are being reduced. City staff will be able to perform this work using the software to obtain timely results. A full emissions inventory at the community- and municipal-scale should be completed in five-year increments. Monitoring and verifying results is Milestone 5 of ICLEI's Cities for Climate Protection process.

\subsection{Existing city actions to address climate change}

The following is a list of projects, programs, actions and policies that the City of San Luis Obispo has implemented in an effort to improve energy efficiency in city services and processes, to promote sustainable land use and transportation policies, to develop sustainable business practices, and make energy conservation a regular part of everyday municipal operations.

- Conservation and Open Space Element of the General Plan contains policies that support energy efficiency.

- Energy audits have been conducted for several city facilities to identify areas where improvements may be made to achieve greater energy efficiency.

- Recycled water has been developed to meet community needs for landscape irrigation for public parks and city facilities.

- Greenbelt program to acquire open space.

- "Pay as you throw" rate system for solid waste encourages recycling.

- High efficiency boilers are used at City Hall and the Police Station, resulting in lower heating costs.

- Installation of one $60 \mathrm{~kW}$ micro-turbine at the SLO Swim Center generates almost enough electricity to power the complex while adding 500,000 Btus of heat to the pool.

- Electronic ballasts are used in all fluorescent lighting (low energy and no PCBs). No incandescent lamps are used because they waste energy and burn out more often.

- Motion-detection lighting controls are installed in common areas.

- Only fluorescent lamps (T8 and biax) or High Intensity Discharge (HID) lamps (such as high pressure sodium and metal halide) are used. They use much less power, have no PCBs and contain little, if any, mercury. 
- Solar panels are located on the Utilities Administration Building and the Ludwick Community Center that each generates about $8 \mathrm{~kW}$.

- High-technology energy management systems are installed at seven major City office buildings (City Hall, Palm Street Parking Garage/City Offices, Police Department, Parks and Recreation, the Swim Center, Fire Station One headquarters, and the Corporation Yard).

- Energy efficient pumps and motors have been installed on City water pumping facilities.

- Installation of eight $30 \mathrm{~kW}$ micro-turbines and other energy saving measures at the Water Reclamation Facility that will save about $50,000 \mathrm{kWh}$ of electricity and about $\$ 200,000$ per year.

- Four hybrid vehicles were recently added to the City's vehicle fleet.

- City program provides cash or vacation day incentives to employees for automobile trip reduction efforts.

- Extensive bike trail system to encourage use of bicycle commuting.

- Recycled oil used in city fleet vehicles.

- Purchasing policies support use of recycled materials and City recycles paper and other supplies. In addition, the City's policy requires double-sided printing for hard-copy distribution of public materials. 


\section{LIST OF REFERENCES}

California Climate Action Registry. (April 2008). California climate action registry general reporting protocol: Reporting entity-wide greenhouse gas emissions. Version 3.0.

City of Benicia. (September 2008). Greenhouse gas emissions inventory report. Benicia: Author.

City of Berkeley. (April 2007). 2005 City of Berkeley baseline greenhouse gas emissions inventory report. ICLEI-Local Governments for Sustainability: Author.

City of Chico. (April 2008). Community and municipal greenhouse gas and criteria air pollutant emissions inventory. Chico: Author. (author - Daniel Salazar)

City of Davis. (March 2008). Greenhouse gas inventory and forecast report. Davis: Author. (author Christa Clark Jones)

City of Hayward. (June 2008). 2005 Baseline greenhouse gas emissions inventory report. ICLEI-Local Governments for Sustainability: Author.

City of Menlo Park. (November 2007). Greenhouse gas emissions analysis. Menlo Park: Author (author - Micah Lang).

City of Pittsburg. (October 2009). 2005 Greenhouse gas emissions baseline inventory and analysis. Pittsburg: Author (author - Miya Kitahara).

City of Santa Cruz. (August 2008). Greenhouse gas emissions inventory: 2005 municipal and community emissions. Santa Cruz: Author. (authors - Ross Clark and Charlie Lewis)

City of San Luis Obispo. (1994). City of San Luis Obispo general plan. San Luis Obispo: Author.

City of San Luis Obispo. (2008). City of San Luis Obispo environmental stewardship report: A summary of resource protection in the city. San Luis Obispo: Author.

County of San Luis Obispo. (April 2009). Community-wide and county government operations: 2006 baseline greenhouse gas emissions inventory. Pacific Municipal Consultants: Author.

ICLEI-Local Governments for Sustainability. Cities for climate protection: Milestone guide. Retrieved September 2, 2008, from ICLEI: http://www.icleiusa.org/action-center/tools.

ICLEI-Local Governments for Sustainability. Clean air climate protection software 2006. Retrieved February 10, 2008, from ICLEI: http://www.icleiusa.org/action-center/tools.I 
Intergovernmental Panel on Climate Change. (2007) Fourth assessment report: Climate change 2007 (Synthesis report summary for policymakers). Retrieved June 1, 2008, from http://www.ipcc.ch.

State of California, Air Resources Board. (November 2007). California 1990 greenhouse gas emissions level and 2020 emissions limits: staff report, Sacramento, California.

State of California, Air Resources Board. (December 2008). Climate change scoping plan: A framework for change, Sacramento, California.

State of California, Air Resources Board, et al. (September 2008). Local government operations protocol: For the quantification and reporting of greenhouse gas emissions inventories. Version 1.0 .

State of California, Department of Finance. E-5 population and housing estimates for cities, counties and the state, 2001-2008, with 2000 benchmark. Sacramento, California, May 2008.

State of California, Department of Transportation. California Public Road Data. Multi-year data sets retrieved January 16, 2010, from Division of Transportation System Information: http://www.dot.ca.gov/hq/tsip/hpms/datalibrary.php.

State of California, Energy Commission. (October 1990). 1988 inventory of California greenhouse gas emissions: final staff report. Sacramento, California.

State of California, Energy Commission. (March 1997). California's greenhouse gas emissions inventory 1990, Sacramento, California, P500-97-004.

State of California, Energy Commission. (January 1998). Appendix A. Historical and forecasted emissions inventories for California, Sacramento, California, P500-98-011V3.

State of California, Energy Commission. (December 2006). Inventory of California greenhouse gas emissions and sinks: 1990-2004, Sacramento, California, CEC-600-2006-013-SF.

State of California, Integrated Waste Management Board. (2004). Statewide waste characterization study, Sacramento, California.

United Nations. (1998). Kyoto protocol to the United Nations Framework Convention on Climate Change.

U.S. Conference of Mayors, et al. (September 2006). U.S. mayors' climate protection agreement: Climate action handbook. 


\section{Appendix A-Detailed community emission inventory figures and notes}

Table A.1: Buildings and facilities electricity usage and emissions (2005)

\begin{tabular}{|c|c|c|c|c|c|c|c|c|}
\hline Building/Facility & Category & Address/Location & $\begin{array}{c}\text { Annual } \\
\text { Electricity } \\
\text { Usage } \\
(\mathrm{kWh})^{*}\end{array}$ & $\begin{array}{c}\text { Daily } \\
\text { Electricity } \\
\text { Usage } \\
(\mathrm{kWh})\end{array}$ & $\begin{array}{c}\text { Annual } \\
\text { electricity } \\
\text { cost* }^{*}\end{array}$ & $\begin{array}{c}\text { Daily } \\
\text { electricity } \\
\text { cost }\end{array}$ & $\begin{array}{c}\text { Equivalent } \\
\mathrm{CO}_{2} \\
\text { (metric } \\
\text { tons) }\end{array}$ & $\begin{array}{c}\text { Energy } \\
\text { (MMBTU) }\end{array}$ \\
\hline Corporation Yard Well & Corp Yard & 25 Prado $\mathrm{Rd}$ & 1,913 & 5.2 & 391 & 1.07 & 0.4 & 7 \\
\hline Canet Adobe & Cultural & 466 Dana St - Unit Res & 514 & 1.4 & 86 & 0.24 & 0.1 & 2 \\
\hline City/County Library & Cultural & 995 Palm St & 33,897 & 92.9 & $\$ \quad 4,908$ & $\$ 13.45$ & 7.7 & 116 \\
\hline Ludwick Community Center & Cultural & 864 Santa Rosa St & 46,097 & 126.3 & $\$ \quad 7,141$ & $\begin{array}{ll}\$ & 19.57 \\
\end{array}$ & 10.5 & 157 \\
\hline Rodriguez Adobe & Cultural & 1341 Purple Sage Ln & 711 & 1.9 & 185 & 0.51 & 0.2 & 2 \\
\hline Senior Citizen Center & Cultural & 1445 Santa Rosa St & 18,326 & 50.2 & $\$ 3,419$ & 9.37 & 4.2 & 63 \\
\hline SLO County Historical Museum & Cultural & 690 Monterey St & 11,505 & 31.5 & $\$ \quad 2,060$ & 5.64 & 2.6 & 39 \\
\hline Little Theatre/Old City Library & Cultural & 888 Morro St & 41,383 & 113.4 & $\$ \quad 4,615$ & $\$ \quad 12.64$ & 9.4 & 141 \\
\hline Fire Station \#1 & Fire Station & 2160 Santa Barbara St & 122,282 & 335.0 & $\$ 17,504$ & $\$ \quad 47.96$ & 27.8 & 417 \\
\hline Fire Station \#2 & Fire Station & 136 N Chorro St & 19,807 & 54.3 & $\$ \quad 2,776$ & 7.60 & 4.5 & 175 \\
\hline 1940 Santa Barbara St. & Misc. & 1940 Santa Barbara St. & 29,430 & 80.6 & $\$ \quad 4,373$ & $\$ 11.98$ & 6.6 & 100 \\
\hline Amtrak Station & Misc. & Amtrak Station & 1,054 & 2.9 & 244 & 0.67 & 0.2 & 4 \\
\hline Fishing Facility Building & Misc. & Cypress Mountain Dr & 0 & 0.0 & 95 & 0.26 & 0 & 10 \\
\hline Fountain (Osos \& Railroad) & Misc. & Osos \& Railroad & 4,069 & 11.1 & 625 & 1.71 & 0.9 & 14 \\
\hline Hydro Building & Misc. & at bottom of dam & 0 & 0.0 & $\$$ & 0.00 & 0 & 0 \\
\hline Lot 2 Restrooms & Misc. & 736 Marsh St & 2,762 & 7.6 & 498 & 1.36 & 0.6 & 9 \\
\hline Office $\&$ shop buildings & Misc. & Old Creek Rd & 7,843 & 21.5 & $\$ \quad 1,357$ & 3.72 & 1.8 & 27 \\
\hline Portola Fountain & Misc. & Archer \& Marsh & 7,911 & 21.7 & $\$ \quad 1,266$ & 3.47 & 1.8 & 27 \\
\hline Pump house adjacent to Pacific HS & Misc. & 11950 LOVR (near Pacific HS) & 100,534 & 275.4 & $\$ 12,082$ & $\$ 33.10$ & 22.9 & 343 \\
\hline Range & Misc. & at Reservoir Cyn \& Fox Hollow & 4,517 & 12.4 & 748 & 2.05 & 1.0 & 15 \\
\hline Rented office & Misc. & 1260 Chorro St \#A & 50,293 & 137.8 & $\$ 7,583$ & $\$ 20.77$ & 11.4 & 172 \\
\hline Spanish Oaks \& Sweet Bay & Misc. & Spanish Oaks \& Sweet Bay & 4,343 & 11.9 & 719 & 1.97 & 1.0 & 15 \\
\hline Tank Farm \& Wavertree & Misc. & 4542 Wavertree St & 1,054 & 2.9 & 245 & 0.67 & 0.2 & 4 \\
\hline City Hall & Office & 990 Palm St & 313,026 & 857.6 & $\$ 42,800$ & $\$ 117.26$ & 70.0 & 1,068 \\
\hline Parks \& Rec Office & Office & 1341 Nipomo St & 48,522 & 132.9 & $\$ \quad 6,909$ & $\$ \quad 18.93$ & 11.0 & 166 \\
\hline
\end{tabular}


Table A.1: Buildings and facilities electricity usage and emissions (2005) (cont'd.)

\begin{tabular}{|c|c|c|c|c|c|c|c|c|}
\hline Building/Facility & Category & Address/Location & $\begin{array}{c}\text { Annual } \\
\text { Electricity } \\
\text { Usage } \\
(\mathrm{kWh})^{*}\end{array}$ & $\begin{array}{c}\text { Daily } \\
\text { Electricity } \\
\text { Usage } \\
(\mathrm{kWh})\end{array}$ & \multicolumn{2}{|c|}{ Annual electricity cost* } & $\begin{array}{c}\text { Daily } \\
\text { electricity } \\
\text { cost }\end{array}$ & $\begin{array}{c}\text { Equivalent } \\
\mathrm{CO}_{2} \\
\text { (metric } \\
\text { tons) }\end{array}$ \\
\hline Public Works Admin & Office & 955 Morro St & 66,442 & 182.0 & \multicolumn{2}{|c|}{ no energy cost data } & 15.1 & 227 \\
\hline Utilities Admin & Office & 879 Morro St & 13,384 & 36.7 & $\$ 2,865$ & $\$ 7.85$ & 3.0 & 46 \\
\hline Damon-Garcia Sports Field & Parks/Rec & 680 Industrial & 51,140 & 140.1 & $\$ 6,506$ & $\begin{array}{ll}\$ 17.82 \\
\end{array}$ & 11.6 & 175 \\
\hline French Park & Parks/Rec & Fuller St/French Park/Irr. P & 11,847 & 32.5 & $\$ 1,791$ & $\$ \quad 4.91$ & 2.7 & 40 \\
\hline Golf Maintenance Shop & Parks/Rec & 11175 Los Osos Valley Rd & 1,310 & 3.6 & $\$ 2,390$ & $\$ \quad 6.55$ & 0.3 & 4 \\
\hline Golf Pro Shop & Parks/Rec & 11175 Los Osos Valley Rd & 21,030 & 57.6 & $\$ 4,169$ & $\$ 11.42$ & 4.8 & 72 \\
\hline Islay Hill Park & Parks/Rec & 1511 Tank Farm Rd & 9,377 & 25.7 & $\$ 1,499$ & $\$ \quad 4.11$ & 2.1 & 32 \\
\hline Johnson Park & Parks/Rec & 2875 Augusta $\mathrm{St}$ & 946 & 2.6 & 207 & $\$ \quad 0.57$ & 0.2 & 3 \\
\hline Johnson Ranch & Parks/Rec & 5182 Ontario Rd & 5,150 & 14.1 & 659 & $\$ \quad 1.81$ & 1.2 & 18 \\
\hline Laguna Lake & Parks/Rec & Madonna Rd at Laguna Lake & 2,662 & 7.3 & 477 & $\$ \quad 1.31$ & 0.6 & 19 \\
\hline Meadow Park & Parks/Rec & 2333 Meadow St & 18,817 & 51.6 & $\$ 1,953$ & $\$ \quad 5.35$ & 4.3 & 64 \\
\hline Meadow Park (end of King St.) & Parks/Rec & south end of King St & 2,791 & 7.6 & 367 & $\$ \quad 1.01$ & 0.6 & 10 \\
\hline Mirada Court Park & Parks/Rec & Mirada Court Park & 1,041 & 2.9 & 243 & $\$ \quad 0.67$ & 0.2 & 4 \\
\hline Mission Plaza (1) & Parks/Rec & Monterey \& Chorro & 3,333 & 9.1 & 580 & $\$ \quad 1.59$ & 0.8 & 11 \\
\hline Mission Plaza (2) & Parks/Rec & Monterey \& Broad & 21,617 & 59.2 & $\$ \quad 2,469$ & $\$ \quad 6.76$ & 4.9 & 74 \\
\hline RST (end of Del Campo Rd) & Parks/Rec & end of Del Campo Rd & 4,347 & 11.9 & 725 & $\$ \quad 1.99$ & 1.0 & 15 \\
\hline Santa Rosa Park (1) & Parks/Rec & Santa Rosa St (Murray St) & 25,602 & 70.1 & $\$ 2,845$ & $\$ 7.79$ & 5.8 & 87 \\
\hline Santa Rosa Park (2) & Parks/Rec & Santa Rosa St & 11,958 & 32.8 & $\$ \quad 1,442$ & $\$ \quad 3.95$ & 2.7 & 41 \\
\hline Santa Rosa Park (3) & Parks/Rec & 190 Santa Rosa St \#C & 7,056 & 19.3 & $\$ \quad 1,225$ & $\$ \quad 3.35$ & 1.6 & 24 \\
\hline Sinsheimer Park (1) & Parks/Rec & Sinsheimer Park (Laurel Ln) & 34,863 & 95.5 & $\$ \quad 4,256$ & $\$ \quad 5.64$ & 7.9 & 119 \\
\hline Sinsheimer Park (2) & Parks/Rec & Southwood Dr (Sinsheimer) & 57,270 & 156.9 & $\$ \quad 5,564$ & $\$ \quad 12.64$ & 13.0 & 195 \\
\hline SLO Swim Center & Parks/Rec & 902 Southwood Dr & 391,497 & $1,072.6$ & $\$ 51,035$ & $\$ 139.82$ & 89.1 & 1,336 \\
\hline Marsh St Pkg Structure & Pkg Structure & 871 Marsh/1260 Chorro Ste B & 134,646 & 368.9 & $\$ 14,923$ & $\$ \quad 40.88$ & 30.6 & 460 \\
\hline Marsh St Pkg Structure Expansion & Pkg Structure & 860 Pacific St & 177,289 & 485.7 & $\$ 17,577$ & $\$ 48.16$ & 40.3 & 605 \\
\hline Palm St Parking Structure & Pkg Structure & 842 Palm St & 132,715 & 363.6 & $\$ 15,589$ & $\$ \quad 42.71$ & 30.2 & 453 \\
\hline \multicolumn{3}{|l|}{ All Buildings \& Facilities } & $2,855,764$ & $7,823.9$ & $\$ 365,602$ & $\$ 993.04$ & 647.8 & 9,838 \\
\hline
\end{tabular}

Source: City of San Luis Obispo, Utilities Department

${ }^{*}$ Extrapolated over 365 days when annual energy bill data is incomplete 
Table A.2: Buildings and facilities natural gas usage and emissions (2005)

\begin{tabular}{|c|c|c|c|c|c|c|c|c|}
\hline Building/Facility & Category & Address/Location & $\begin{array}{l}\text { Annual } \\
\text { Natural } \\
\text { Gas } \\
\text { Usage } \\
\text { (therms) }\end{array}$ & $\begin{array}{l}\text { Daily } \\
\text { Natural } \\
\text { Gas Usage } \\
\text { (therms) }\end{array}$ & $\begin{array}{c}\text { Total } \\
\text { Natural } \\
\text { Gas Cost }\end{array}$ & $\begin{array}{c}\text { Daily } \\
\text { Natural } \\
\text { Gas Cost }\end{array}$ & $\begin{array}{l}\text { Equivalent } \\
\mathrm{CO}_{2} \\
\text { (metric tons) }\end{array}$ & $\begin{array}{c}\text { Energy } \\
\text { (MMBTU) }\end{array}$ \\
\hline Corporation Yard & Corp Yard & 25 Prado $\mathrm{Rd}$ & 7,365 & 20.2 & $\$ 7,759$ & $\$ 21.26$ & 39.2 & 737 \\
\hline Jack House & Cultural & 535 Marsh Street & 156 & 0.4 & $\$ 287$ & $\$ \quad 0.79$ & 0.8 & 16 \\
\hline Ludwick Community Center & Cultural & 864 Santa Rosa St & 1,126 & 3.1 & $\$ 1,437$ & $\$ \quad 3.94$ & 6.0 & 113 \\
\hline Senior Citizen Center & Cultural & 1445 Santa Rosa St & 1,291 & 3.5 & $\$ 1,668$ & $\$ \quad 4.57$ & 6.9 & 129 \\
\hline SLO County Historical Museum & Cultural & 696 Monterey St & 256 & 0.7 & 424 & $\$ \quad 1.16$ & 1.4 & 26 \\
\hline SLO Little Theatre/Old City Library & Cultural & 888 Morro St & 236 & 0.6 & $\$ \quad 387$ & $\$ \quad 1.06$ & 1.3 & 24 \\
\hline Fire Station \#1 & Fire Station & 2160 Santa Barbara & 2,407 & 6.6 & $\$ 2,802$ & $\$ 7.68$ & 12.8 & 241 \\
\hline Fire Station \#3 & Fire Station & 1284 Laurel Ln & 1,110 & 3.0 & $\$ 1,458$ & $\$ \quad 3.99$ & 5.9 & 111 \\
\hline Fire Station \#4 & Fire Station & 1395 Madonna & 959 & 2.6 & $\$ 1,259$ & $\$ 3.45$ & 5.1 & 96 \\
\hline City Hall & Office & 990 Palm St & 9,933 & 27.2 & $\$ 10,402$ & $\$ 28.50$ & 52.8 & 993 \\
\hline Parks \& Recreation offices & Office & 1341 Nipomo St & 693 & 1.9 & 923 & $\$ 2.53$ & 3.7 & 69 \\
\hline Police Department & Office & 1042 Walnut St & 14,344 & 39.3 & $\$ 14,484$ & $\$ 39.68$ & 76.3 & 1,434 \\
\hline PW/CDD offices & Office & 919 Palm St & off-line & off-line & -- & - & - & - \\
\hline Utilities Administration & Office & 879 Morro St & 565 & 1.5 & 763 & 2.09 & 3.0 & 57 \\
\hline Laguna Lake Golf Course & Parks/Rec & 11175 LOVR & 352 & 1.0 & 512 & $\$ \quad 1.40$ & 1.9 & 35 \\
\hline Meadow Park & Parks/Rec & 2333 Meadow & 144 & 0.4 & 261 & $\begin{array}{ll}\$ & 0.71 \\
\end{array}$ & 0.8 & 14 \\
\hline Southwood Pool & Swim Center & 900 Southwood & 58,391 & 160.0 & $\$ 57,226$ & $\$ 156.78$ & 310.6 & 5,839 \\
\hline \multicolumn{3}{|l|}{ All Buildings \& Facilities } & 99,328 & 272.0 & $\$ 102,052$ & $\$ 279.59$ & 528.5 & 9,934 \\
\hline
\end{tabular}

Source: City of San Luis Obispo, Utilities Department 
Table A.3: Streetlights and traffic signals electricity usage and emissions (2005)

\begin{tabular}{|c|c|c|c|c|c|c|c|}
\hline Streetlight & Category & $\begin{array}{l}\text { Annual } \\
\text { Electricity } \\
\text { Usage } \\
(\mathrm{kWh})^{*}\end{array}$ & $\begin{array}{c}\text { Daily } \\
\text { Electricity } \\
\text { Usage } \\
\text { (kWh) }\end{array}$ & $\begin{array}{l}\text { Annual } \\
\text { electricity } \\
\text { cost* }^{*}\end{array}$ & $\begin{array}{c}\text { Daily } \\
\text { electricity } \\
\text { cost }\end{array}$ & $\begin{array}{l}\text { Equivalent } \\
\mathrm{CO}_{2} \\
\text { (metric } \\
\text { tons) }\end{array}$ & $\begin{array}{c}\text { Energy } \\
\text { (MMBTU) }\end{array}$ \\
\hline City-owned street lighting & Streetlights & 415,536 & $1,138.5$ & $\$ 114,340$ & $\$ 313.26$ & 93.0 & 1,419 \\
\hline PG\&E-owned street lighting & Streetlights & 1,921 & 5.3 & \multicolumn{2}{|c|}{ no energy cost data } & 0.0 & 7 \\
\hline Johnson Ave underpass & Underpass lighting & 1,876 & 5.1 & $\$ 403$ & $\$ \quad 1.11$ & 0.4 & 6 \\
\hline Broad \& Buchon & Traffic Signal & 1,828 & 5.0 & $\$ 363$ & $\$ \quad 1.00$ & 0.4 & 6 \\
\hline Broad \& Pismo & Traffic Signal & 1,991 & 5.5 & $\$ 354$ & $\begin{array}{ll} & 0.97\end{array}$ & 0.4 & 7 \\
\hline California \& Mill & Traffic Signal & 2,884 & 7.9 & $\$ \quad 470$ & $\$ \quad 1.29$ & 0.6 & 10 \\
\hline California \& Monterey & Traffic Signal & 3,452 & 9.5 & 544 & $\$ \quad 1.49$ & 0.8 & 12 \\
\hline Chorro \& Palm & Traffic Signal & 1,092 & 3.0 & 236 & $\$ \quad 0.65$ & 0.2 & 4 \\
\hline Foothill \& California & Traffic Signal & 4,237 & 11.6 & 645 & $\$ \quad 1.77$ & 0.9 & 14 \\
\hline Foothill \& Chorro & Traffic Signal & 6,815 & 18.7 & 976 & $\$ 2.67$ & 1.5 & 23 \\
\hline Foothill \& Patricia & Traffic Signal & 2,620 & 7.2 & 438 & $\$ \quad 1.20$ & 0.6 & 9 \\
\hline Foothill \& Tassajara & Traffic Signal & 2,944 & 8.1 & 482 & $\$ \quad 1.32$ & 0.7 & 10 \\
\hline Grand \& Palm & Traffic Signal & 3,596 & 9.9 & 563 & $\$ \quad 1.54$ & 0.8 & 12 \\
\hline Higuera \& Broad & Traffic Signal & 5,867 & 16.1 & 848 & $\$ \quad 2.32$ & 1.3 & 20 \\
\hline Higuera \& Chorro & Traffic Signal & 6,017 & 16.5 & 866 & $\begin{array}{ll}\$ \quad 2.37\end{array}$ & 1.3 & 21 \\
\hline Higuera \& High & Traffic Signal & 8,307 & 22.8 & $\$ 1,173$ & $\$ \quad 3.21$ & 1.9 & 28 \\
\hline Higuera \& Marsh & Traffic Signal & 2,979 & 8.2 & 484 & $\begin{array}{ll}\$ 1.33 \\
\end{array}$ & 0.7 & 10 \\
\hline Higuera \& Morro & Traffic Signal & 6,038 & 16.5 & 870 & $\$ \quad 2.38$ & 1.4 & 21 \\
\hline Higuera \& Nipomo & Traffic Signal & 5,675 & 15.5 & 922 & $\$ 2.53$ & 1.3 & 19 \\
\hline Higuera \& Osos & Traffic Signal & 5,865 & 16.1 & 850 & $\$ 2.33$ & 1.3 & 20 \\
\hline Johnson \& Bishop & Traffic Signal & 3,317 & 9.1 & 527 & $\$ \quad 1.44$ & 0.7 & 11 \\
\hline Johnson \& Laurel & Traffic Signal & 5,797 & 15.9 & 887 & $\$ \quad 2.43$ & 1.3 & 20 \\
\hline Johnson \& Lizzie & Traffic Signal & 4,666 & 12.8 & 699 & $\$ \quad 1.92$ & 1.0 & 16 \\
\hline Johnson \& San Luis & Traffic Signal & 4,778 & 13.1 & 713 & $\$ \quad 1.95$ & 1.1 & 16 \\
\hline LOVR \& Calle Joaquin & Traffic Signal & off-line & off-line & - & -- & -- & -- \\
\hline LOVR \& Descanso & Traffic Signal & 3,334 & 9.1 & 530 & $\$ \quad 1.45$ & 0.7 & 11 \\
\hline LOVR \& Froom Ranch & Traffic Signal & 3,593 & 9.8 & 563 & $\$ \quad 1.54$ & 0.8 & 12 \\
\hline LOVR \& Laguna & Traffic Signal & 3,328 & 9.1 & 529 & $\$ \quad 1.45$ & 0.7 & 11 \\
\hline LOVR \& Madonna & Traffic Signal & 8,651 & 23.7 & $\$ 1,220$ & $\$ \quad 3.34$ & 1.9 & 30 \\
\hline LOVR \& Royal & Traffic Signal & 4,281 & 11.7 & 652 & $\begin{array}{ll}\$ 1.79 \\
\end{array}$ & 1.0 & 15 \\
\hline
\end{tabular}


Table A.3: Streetlights and traffic signals electricity usage and emissions (2005) (cont'd)

\begin{tabular}{|c|c|c|c|c|c|c|c|c|c|}
\hline \multirow{2}{*}{$\begin{array}{l}\text { Streetlight } \\
\text { Madonna \& Dalidio }\end{array}$} & \multirow{2}{*}{$\begin{array}{r}\text { Category } \\
\text { Traffic Signal } \\
\end{array}$} & \multirow{2}{*}{$\begin{array}{l}\begin{array}{c}\text { Annual } \\
\text { Electricity } \\
\text { Usage } \\
(\mathrm{kWh})^{*}\end{array} \\
3,270\end{array}$} & \multirow{2}{*}{$\begin{array}{l}\text { Daily } \\
\text { Electricity } \\
\text { Usage } \\
\text { (kWh) } \\
9.0\end{array}$} & \multicolumn{2}{|c|}{$\begin{array}{l}\text { Annual } \\
\text { electricity } \\
\text { cost* }^{*}\end{array}$} & \multicolumn{2}{|c|}{$\begin{array}{l}\text { Daily } \\
\text { electricity } \\
\text { cost }\end{array}$} & \multirow{2}{*}{$\begin{array}{l}\begin{array}{l}\text { Equivalent } \\
\mathrm{CO}_{2} \\
\text { (metric } \\
\text { tons) }\end{array} \\
0.7\end{array}$} & \multirow{2}{*}{$\begin{array}{r}\begin{array}{c}\text { Energy } \\
\text { (MMBTU) }\end{array} \\
11\end{array}$} \\
\hline & & & & $\$$ & 519 & $\$$ & 1.42 & & \\
\hline Madonna \& El Mercado & Traffic Signal & 3,727 & 10.2 & $\$$ & 578 & $\$$ & 1.58 & 0.8 & 13 \\
\hline Madonna \& Oceanaire & Traffic Signal & 4,603 & 12.6 & $\$$ & 696 & $\$$ & 1.91 & 1.0 & 16 \\
\hline Marsh \& Broad & Traffic Signal & 4,257 & 11.7 & $\$$ & 649 & $\$$ & 1.78 & 1.0 & 15 \\
\hline Marsh \& Chorro & Traffic Signal & 3,962 & 10.9 & $\$$ & 613 & $\$$ & 1.68 & 0.9 & 14 \\
\hline Marsh \& Johnson & Traffic Signal & 2,971 & 8.1 & $\$$ & 495 & $\$$ & 1.36 & 0.7 & 10 \\
\hline Marsh \& Morro & Traffic Signal & 6,354 & 17.4 & $\$$ & 910 & $\$$ & 2.49 & 1.4 & 22 \\
\hline Marsh \& Nipomo & Traffic Signal & 3,707 & 10.2 & $\$$ & 578 & $\$$ & 1.58 & 0.8 & 13 \\
\hline Marsh \& Osos & Traffic Signal & 4,112 & 11.3 & $\$$ & 623 & $\$$ & 1.71 & 0.9 & 14 \\
\hline Monterey \& Chorro & Traffic Signal & 1,198 & 3.3 & $\$$ & 253 & $\$$ & 0.69 & 0.3 & 4 \\
\hline Monterey \& Johnson & Traffic Signal & 5,750 & 15.8 & $\$$ & 843 & $\$$ & 2.31 & 1.3 & 20 \\
\hline Monterey \& Morro & Traffic Signal & 1,302 & 3.6 & $\$$ & 284 & $\$$ & 0.78 & 0.3 & 4 \\
\hline Monterey \& Osos & Traffic Signal & 1,567 & 4.3 & $\$$ & 301 & $\$$ & 0.82 & 0.4 & 5 \\
\hline Osos \& Buchon & Traffic Signal & 3,145 & 8.6 & $\$$ & 504 & $\$$ & 1.38 & 0.7 & 11 \\
\hline Osos \& Pismo & Traffic Signal & 4,943 & 13.5 & $\$$ & 737 & $\$$ & 2.02 & 1.1 & 17 \\
\hline South Higuera \& LOVR & Traffic Signal & 3,458 & 9.5 & $\$$ & 545 & $\$$ & 1.49 & 0.8 & 12 \\
\hline South Higuera \& Margarita & Traffic Signal & 2,735 & 7.5 & $\$$ & 452 & $\$$ & 1.24 & 0.6 & 9 \\
\hline South Higuera \& Prado & Traffic Signal & 5,696 & 15.6 & $\$$ & 899 & $\$$ & 2.46 & 1.3 & 19 \\
\hline South Higuera \& Suburban & Traffic Signal & 3,116 & 8.5 & $\$$ & 545 & $\$$ & 1.49 & 0.7 & 11 \\
\hline South Higuera \& Tank Farm & Traffic Signal & 5,909 & 16.2 & $\$$ & 864 & $\$$ & 2.37 & 1.3 & 20 \\
\hline Santa Barbara \& Upham & Traffic Signal & 2,282 & 6.3 & $\$$ & 534 & $\$$ & 1.46 & 0.5 & 8 \\
\hline Santa Rosa \& Higuera & Traffic Signal & 5,295 & 14.5 & $\$$ & 785 & $\$$ & 2.15 & 1.2 & 18 \\
\hline Santa Rosa \& Marsh & Traffic Signal & 1,540 & 4.2 & $\$$ & 297 & $\$$ & 0.81 & 0.3 & 5 \\
\hline Santa Rosa \& Mill & Traffic Signal & 4,343 & 11.9 & $\$$ & 653 & $\$$ & 1.79 & 1.0 & 15 \\
\hline Santa Rosa \& Monterey & Traffic Signal & 4,282 & 11.7 & $\$$ & 653 & $\$$ & 1.79 & 1.0 & 15 \\
\hline Santa Rosa \& Palm & Traffic Signal & 3,592 & 9.8 & $\$$ & 562 & $\$$ & 1.54 & 0.8 & 12 \\
\hline \multicolumn{2}{|c|}{ All Streetlights \& Traffic Signals } & 630,401 & $1,727.5$ & &, 519 & & 04.15 & 140.5 & 2,153 \\
\hline
\end{tabular}

Source: City of San Luis Obispo, Utilities Department

* Extrapolated over 365 days when annual energy bill data is incomplete 
Table A.4: Water delivery electricity usage and emissions (2005)

\begin{tabular}{|c|c|c|c|c|c|c|c|c|c|c|}
\hline \multirow{2}{*}{$\begin{array}{l}\text { Water Delivery Facility } \\
108 \text { E. 13th St }\end{array}$} & \multirow{2}{*}{$\begin{array}{l}\text { Category } \\
\text { Misc. } \\
\end{array}$} & \multirow{2}{*}{$\begin{array}{c}\text { Location/Address } \\
\text { Old Creek Rd (Cayucos) }\end{array}$} & \multirow{2}{*}{$\begin{array}{l}\begin{array}{c}\text { Annual Electricity } \\
\text { Usage } \\
(\mathrm{kWh})^{*}\end{array} \\
2,268 \\
\end{array}$} & \multirow{2}{*}{$\begin{array}{c}\begin{array}{c}\text { Daily } \\
\text { Electricity } \\
\text { Usage } \\
(\mathrm{kWh})\end{array} \\
6.2\end{array}$} & \multicolumn{2}{|c|}{$\begin{array}{c}\text { Annual } \\
\text { electricity } \\
\text { cost }^{*}\end{array}$} & \multicolumn{2}{|c|}{$\begin{array}{c}\text { Daily } \\
\text { electricity } \\
\text { cost }\end{array}$} & \multirow{2}{*}{$\begin{array}{c}\begin{array}{c}\text { Equivalent } \\
\mathrm{CO}_{2} \\
\text { (metric } \\
\text { tons) }\end{array} \\
0.5 \\
\end{array}$} & \multirow{2}{*}{$\begin{array}{r}\begin{array}{c}\text { Energy } \\
(\mathrm{MMTBU})\end{array} \\
8\end{array}$} \\
\hline & & & & & $\$$ & 285 & $\$$ & 0.78 & & \\
\hline Bishop Tank Cathodic Prot & Misc. & Flora St @ Viewmont & 110 & 0.3 & $\$$ & 96 & $\$$ & 0.26 & 0.0 & 0 \\
\hline CL2 Bldg \#2 Reservoir & Misc. & Upper Stenner Creek Wtr Plant & 17,113 & 46.9 & $\$$ & 2,185 & $\$$ & 5.99 & 3.8 & 58 \\
\hline Fire St \#4 Well & Misc & Los Osos Valley Rd \& Madonna & 128 & 0.4 & $\$$ & 203 & $\$$ & 0.56 & 0.0 & 0 \\
\hline Hydro Bldg \#2 Reservoir & Misc. & Stenner Creek Rd & 0 & 0.0 & $\$$ & 87 & $\$$ & 0.24 & 0.0 & 0 \\
\hline Radio repeater site & Misc. & Old Creek Rd & 1,809 & 5.0 & $\$$ & 96 & $\$$ & 0.26 & 0.4 & 6 \\
\hline Reservoir \#1 & Misc. & Hwy 101 Reservoir 2 pump & 6,670 & 18.3 & $\$$ & 1,028 & $\$$ & 2.82 & 1.5 & 23 \\
\hline South St. Hill repeater site & Misc. & 0 Higuera St & 11,022 & 30.2 & $\$$ & 1,721 & $\$$ & 4.72 & 2.5 & 38 \\
\hline Transfer Pump House & Misc. & Stenner Creek Rd .75mile & 759,112 & $2,079.8$ & $\$$ & 82,783 & & 226.80 & 169.8 & 2,591 \\
\hline Valve Vault & Misc. & Old Creek Rd & 59 & 0.2 & $\$$ & 402 & $\$$ & 1.10 & 0.0 & 0 \\
\hline Water Wells & Misc. & 11175 Los Osos Valley Rd & 15,207 & 41.7 & $\$$ & 293 & $\$$ & 0.80 & 3.4 & 52 \\
\hline Water Pump Stn (Alrita) & Pump Stn & Laurel Ln \& Flora St & 2,081 & 5.7 & $\$$ & 449 & $\$$ & 1.23 & 0.5 & 7 \\
\hline Water Pump Stn (Bishop) & Pump Stn & Bishop St \& Flora St & 47,121 & 129.1 & $\$$ & 5,567 & $\$$ & 15.25 & 10.5 & 161 \\
\hline Water Pump Stn (Bressi) & Pump Stn & Bressi Pl $400 \mathrm{~S} /$ Serrano & 69,351 & 190.0 & $\$$ & 11,107 & $\$$ & 30.43 & 15.5 & 237 \\
\hline Water Pump Stn (Felmar) & Pump Stn & Between $171 \& 183$ Fel Mar & 22,121 & 60.6 & $\$$ & 3,632 & $\$$ & 9.95 & 4.9 & 75 \\
\hline Water Pump Stn (Ferrini) & Pump Stn & Hwy 1 (1/4 mil n/o Westmont) & 15,203 & 41.7 & $\$$ & 2,480 & $\$$ & 6.79 & 3.4 & 52 \\
\hline Water Pump Stn (McCollom) & Pump Stn & Bond St Station McCollom & 20,422 & 56.0 & $\$$ & 3,270 & $\$$ & 8.96 & 4.6 & 70 \\
\hline Water Pump Stn (Old Creek) & Pump Stn & 108 Old Creek Rd & 694 & 1.9 & $\$$ & 224 & $\$$ & 0.61 & 0.2 & 2 \\
\hline Water Pump Stn (Poly Vault) & Pump Stn & Mustang Dr & 268 & 0.7 & $\$$ & 127 & $\$$ & 0.35 & 0.1 & 1 \\
\hline Water Pump Stn (Rosemont) & Pump Stn & 2 Highland Dr & 1,282 & 3.5 & $\$$ & 287 & $\$$ & 0.79 & 0.3 & 4 \\
\hline Highland Tank & Water Tank & W Highland Dr & 167 & 0.5 & $\$$ & 111 & $\$$ & 0.30 & 0.0 & 1 \\
\hline Main Power Edna Tank & Water Tank & Broad St Edna Saddle & 3 & 0.0 & $\$$ & 131 & $\$$ & 0.36 & 0.0 & 0 \\
\hline Terrace Hill Tank & Water Tank & Terrace Hill Water Tank & 257 & 0.7 & $\$$ & 125 & & 0.34 & 0.1 & 1 \\
\hline Water Treatment Plant & Treatment & Stenner Canyon Dr & $1,260,042$ & $3,452.2$ & & 127,990 & & 350.66 & 281.9 & 4,300 \\
\hline Whale Rock Pump Stn \#1 & Whale Rock & Hwy 1 Pump Stn \#1 (Chaney) & $1,192,765$ & $3,267.8$ & & 118,163 & & 323.73 & 266.8 & 4,071 \\
\hline Whale Rock Pump Stn \#2 & Whale Rock & Hwy 1 Pump Stn \#2 (Gilardi) & $1,218,460$ & $3,338.2$ & & 124,718 & & 341.69 & 272.4 & 4,159 \\
\hline \multicolumn{2}{|c|}{ All Water Delivery Facilities } & & $4,663,735$ & $12,777.6$ & & 487,560 & &, 335.78 & $1,043.3$ & 15,917 \\
\hline
\end{tabular}

Source: City of San Luis Obispo, Utilities Department

* Extrapolated over 365 days when annual energy bill data is incomplete 
Table A.5: Wastewater electricity usage and emissions (2005)

\begin{tabular}{|c|c|c|c|c|c|c|c|c|c|c|}
\hline Wastewater Facility & Category & Location/Address & $\begin{array}{c}\text { Annual } \\
\text { Electricity } \\
\text { Usage } \\
(\mathrm{kWh})^{*}\end{array}$ & $\begin{array}{c}\text { Daily } \\
\text { Electricity } \\
\text { Usage } \\
(\mathrm{kWh})\end{array}$ & & $\begin{array}{l}\text { anual } \\
\text { tricity } \\
\text { ost* }\end{array}$ & $\begin{array}{r}D \\
\text { electri }\end{array}$ & $\begin{array}{l}\text { ily } \\
\text { ty cost }\end{array}$ & $\begin{array}{l}\text { Equivalent } \\
\mathrm{CO}_{2} \\
\text { (metric } \\
\text { tons) }\end{array}$ & $\begin{array}{c}\text { Energy } \\
\text { (MMTBU) }\end{array}$ \\
\hline Sewer Lift Station (Airport) & Lift Station & Hwy 227 (s/o Tank Farm) & 3,830 & 10.5 & $\$$ & 800 & $\$$ & 2.19 & 0.9 & 13 \\
\hline Sewer Lift Station (Calle Joaquin) & Lift Station & LOVR \& Hwy 101 & 19,743 & 54.1 & $\$$ & 3,066 & $\$$ & 8.40 & 4.5 & 67 \\
\hline Sewer Lift Station (Foothill) & Lift Station & Foothill Blvd & 3,552 & 9.7 & $\$$ & 732 & $\$$ & 2.00 & 0.8 & 12 \\
\hline Sewer Lift Station (Madonna Inn) & Lift Station & Madonna Rd at Madonna Inn & 8,279 & 22.7 & $\$$ & 1,334 & $\$$ & 3.66 & 1.9 & 28 \\
\hline Sewer Lift Station (Margarita) & Lift Station & Margarita \& South Higuera & 2,624 & 7.2 & $\$$ & 526 & $\$$ & 1.44 & 0.6 & 9 \\
\hline Sewer Lift Station (Rockview) & Lift Station & Broad \& Rockview & 51,459 & 141.0 & $\$$ & 6,356 & $\$$ & 17.41 & 11.5 & 176 \\
\hline Sewer Lift Station (Silver City) & Lift Station & South Higuera/Silver City & 8,054 & 22.1 & $\$$ & 1,324 & $\$$ & 3.63 & 1.8 & 27 \\
\hline Sewer Lift Station (Tank Farm) & Lift Station & Edna Rd \& Tank Farm Rd & 36,964 & 101.3 & $\$$ & 4,507 & $\$$ & 12.35 & 8.2 & 126 \\
\hline Effluent Structure LOVR & Reclamation & 35 Prado $\mathrm{Rd}$ & 4,963 & 13.6 & $\$$ & 778 & $\$$ & 2.13 & 1.1 & 17 \\
\hline Water Reclamation Facility & Reclamation & 35 Prado Rd (Bldg Electric) & $4,301,206$ & $11,784.1$ & & 471,156 & & 290.84 & 961.3 & 14,680 \\
\hline All Wastewater Facilities & & & $4,440,674$ & $12,166.3$ & $\$$ & 490,579 & & 344.05 & 992.6 & 15,155 \\
\hline
\end{tabular}

Source: City of San Luis Obispo, Utilities Department

* Extrapolated over 365 days when annual energy bill data is incomplete

Table A.6: Wastewater natural gas usage and emissions (2005)

\begin{tabular}{|c|c|c|c|c|c|c|c|}
\hline Wastewater Facility & Address/Location & $\begin{array}{c}\text { Annual } \\
\text { Natural } \\
\text { Gas Usage } \\
\text { (Therms) }\end{array}$ & $\begin{array}{c}\text { Daily } \\
\text { Natural } \\
\text { Gas Usage } \\
\text { (Therms) }\end{array}$ & $\begin{array}{c}\text { Total } \\
\text { Natural } \\
\text { Gas Cost }\end{array}$ & $\begin{array}{c}\text { Daily } \\
\text { Natural } \\
\text { Gas Cost }\end{array}$ & $\begin{array}{c}\text { Equivalent } \\
\mathrm{CO}_{2} \\
(\mathrm{metric} \\
\text { tons) }\end{array}$ & $\begin{array}{c}\text { Energy } \\
(\mathrm{MMBTU})\end{array}$ \\
\hline Water Reclamation Facility & 35 Prado Rd & 34,279 & 93.9 & $\$ 34,143$ & $\$ 93.54$ & 182.4 & 3,428 \\
\hline
\end{tabular}

Source: City of San Luis Obispo, Utilities Department 
Table A.7: Community transportation sector emissions (2005)

\begin{tabular}{|c|c|c|c|c|c|c|c|c|c|}
\hline $\begin{array}{l}\text { Count } \\
\text { Location }\end{array}$ & Street & Segment & VMT Sub-area & $\begin{array}{c}\text { Street } \\
\text { Classification }\end{array}$ & $\begin{array}{l}\text { Segment } \\
\text { Length } \\
\text { (miles) }\end{array}$ & $\mathrm{ADT}$ & $\begin{array}{l}\text { Daily } \\
\text { VMT } \\
\text { (Length x } \\
\text { Volume) } \\
\end{array}$ & $\begin{array}{c}\text { Annual VMT } \\
\text { (Daily VMT x } \\
365 \text { ) }\end{array}$ & $\begin{array}{l}\text { Equivalent } \mathrm{CO}_{2} \\
\text { (metric tons) }\end{array}$ \\
\hline 1 & Broad & Ramona to Murray & Santa Rosa/Foothill & Collector & 0.13 & 5,051 & 648 & 236,388 & 112 \\
\hline 2 & Broad & Murray to Mission & Santa Rosa/Foothill & Collector & 0.17 & 4,255 & 711 & 259,434 & 123 \\
\hline 3 & Broad & Mission to Lincoln & Santa Rosa/Foothill & Collector & 0.32 & 3,855 & 1,238 & 451,703 & 213 \\
\hline 4 & Broad & Lincoln to Hwy 101 & Santa Rosa/Foothill & Collector & 0.06 & 4,506 & 254 & 92,825 & 44 \\
\hline 5 & Broad & HWY 101 to Palm & Downtown/Uptown & Collector & 0.17 & 2,583 & 441 & 161,061 & 76 \\
\hline 6 & Broad & Higuera to Marsh & Downtown/Uptown & Major Arterial & 0.06 & 7,532 & 489 & 178,593 & 84 \\
\hline 7 & Broad & Marsh to Pismo & Downtown/Uptown & Major Arterial & 0.13 & 9,402 & 1,197 & 436,766 & 206 \\
\hline 8 & Broad & Pismo to Church & Downtown/Uptown & Major Arterial & 0.27 & 10,728 & 2,885 & $1,053,091$ & 497 \\
\hline 9 & Broad & Church to South & Broad/South & Major Arterial & 0.33 & 13,801 & 4,506 & $1,644,776$ & 777 \\
\hline 10 & Broad & South to Lawrence & Broad/South & Major Arterial & 0.45 & 29,103 & 12,959 & $4,729,871$ & 2,234 \\
\hline 11 & Broad & Lawrence to Orcutt & Broad/South & Major Arterial & 0.23 & 28,176 & 6,468 & $2,360,701$ & 1,115 \\
\hline 12 & Broad & Orcutt to Capitolio & Tank Farm/Broad & Major Arterial & 0.37 & 30,549 & 11,421 & $4,168,723$ & 1,969 \\
\hline 13 & Broad & Capitolio to Industrial & Tank Farm/Broad & Major Arterial & 0.39 & 24,935 & 9,757 & $3,561,219$ & 1,682 \\
\hline 14 & Broad & Industrial to Tank Farm & Tank Farm/Broad & Major Arterial & 0.22 & 21,700 & 4,772 & $1,741,610$ & 822 \\
\hline 15 & Broad & Tank Farm to Fuller & Tank Farm/Broad & Major Arterial & 0.32 & 20,598 & 6,554 & $2,392,177$ & 1,130 \\
\hline 16 & Broad & Fuller to Aero & Tank Farm/Broad & Major Arterial & 0.24 & 19,476 & 4,578 & $1,670,823$ & 789 \\
\hline 17 & Broad & Aero to City Limits & Tank Farm/Broad & Major Arterial & 0.16 & 17,708 & 2,784 & $1,016,030$ & 480 \\
\hline 18 & Buena Vista & Loomis to Monterey & Downtown/Uptown & Collector & 0.15 & 4,509 & 656 & 239,387 & 113 \\
\hline 19 & California & Campus to Foothill & Cal Poly area (e/o Santa Rosa) & Major Arterial & 0.10 & 9,266 & 909 & 331,804 & 157 \\
\hline 20 & California & Foothill to Hathway & Cal Poly area (e/o Santa Rosa) & Major Arterial & 0.22 & 9,617 & 2,146 & 783,148 & 370 \\
\hline 21 & California & Hathway to Taft & Cal Poly area (e/o Santa Rosa) & Major Arterial & 0.13 & 11,798 & 1,548 & 565,198 & 267 \\
\hline 22 & California & Taft to Phillips & Downtown/Uptown & Major Arterial & 0.27 & 13,645 & 3,646 & $1,330,943$ & 629 \\
\hline 23 & California & Phillips to Monterey & Downtown/Uptown & Major Arterial & 0.20 & 9,290 & 1,842 & 672,390 & 318 \\
\hline 24 & California & Monterey to Marsh & Downtown/Uptown & Major Arterial & 0.11 & 11,343 & 1,285 & 468,908 & 221 \\
\hline 25 & California & Marsh to San Luis & Downtown/Uptown & Major Arterial & 0.04 & 10,218 & 453 & 165,288 & 78 \\
\hline 26 & Capitolio & Broad to Sacramento & Tank Farm/Broad & Collector & 0.17 & 4,252 & 711 & 259,545 & 123 \\
\hline 27 & Chorro & Highland to Foothill & Santa Rosa/Foothill & Collector & 0.33 & 6,913 & 2,274 & 830,090 & 392 \\
\hline 28 & Chorro & Foothill to Murray & Santa Rosa/Foothill & Minor Arterial & 0.25 & 7,228 & 1,780 & 649,562 & 307 \\
\hline 29 & Chorro & Murray to Center & Santa Rosa/Foothill & Minor Arterial & 0.28 & 7,606 & 2,123 & 775,020 & 366 \\
\hline 30 & Chorro & Center to Lincoln & Santa Rosa/Foothill & Minor Arterial & 0.15 & 8,038 & 1,168 & 426,189 & 201 \\
\hline 31 & Chorro & Lincoln to Palm & Downtown/Uptown & Minor Arterial & 0.31 & 7,974 & 2,477 & 904,022 & 427 \\
\hline 32 & Chorro & Monterey to Higuera & Downtown/Uptown & Minor Arterial & 0.06 & 8,016 & 466 & 170,120 & 80 \\
\hline
\end{tabular}


Table A.7: Community transportation sector emissions (2005) (cont'd)

\begin{tabular}{|c|c|c|c|c|c|c|c|c|c|}
\hline $\begin{array}{l}\text { Count } \\
\text { Location }\end{array}$ & Street & Segment & VMT Sub-area & $\begin{array}{c}\text { Street } \\
\text { Classification }\end{array}$ & $\begin{array}{l}\text { Segment } \\
\text { Length } \\
\text { (miles) }\end{array}$ & ADT & $\begin{array}{l}\text { Daily } \\
\text { VMT } \\
\text { (Length x } \\
\text { Volume) } \\
\end{array}$ & $\begin{array}{c}\text { Annual VMT } \\
\text { (Daily VMT x } \\
\text { 365) }\end{array}$ & $\begin{array}{l}\text { Equivalent } \mathrm{CO}_{2} \\
\text { (metric tons) }\end{array}$ \\
\hline 33 & Chorro & Higuera to Marsh & Downtown/Uptown & Minor Arterial & 0.06 & 7,910 & 499 & 182,087 & 86 \\
\hline 34 & Chorro & Marsh to Pismo & Downtown/Uptown & Minor Arterial & 0.13 & 5,890 & 761 & 277,689 & 131 \\
\hline 35 & Chorro & Pismo to Upham & Downtown/Uptown & Minor Arterial & 0.33 & 3,879 & 1,272 & 464,437 & 219 \\
\hline 36 & Chorro & Upham to Broad & Broad/South & Minor Arterial & 0.18 & 2,061 & 366 & 133,499 & 63 \\
\hline 37 & Foothill & City Limits to Patricia & Santa Rosa/Foothill & County Highway & 0.33 & 11,699 & 3,869 & $1,412,056$ & 667 \\
\hline 38 & Foothill & Patricia to Tassajara & Santa Rosa/Foothill & Major Arterial & 0.31 & 13,491 & 4,157 & $1,517,367$ & 717 \\
\hline 39 & Foothill & Tassajara to Ferrini & Santa Rosa/Foothill & Major Arterial & 0.24 & 16,629 & 3,930 & $1,434,629$ & 677 \\
\hline 40 & Foothill & Ferrini to Broad & Santa Rosa/Foothill & Major Arterial & 0.12 & 17,072 & 2,102 & 767,108 & 362 \\
\hline 41 & Foothill & Broad to Chorro & Santa Rosa/Foothill & Major Arterial & 0.05 & 20,611 & 1,042 & 380,425 & 180 \\
\hline 42 & Foothill & Chorro to Santa Rosa & Santa Rosa/Foothill & Major Arterial & 0.16 & 18,562 & 2,988 & $1,090,693$ & 515 \\
\hline 43 & Foothill & Santa Rosa to California & Cal Poly area (e/o Santa Rosa) & Major Arterial & 0.26 & 19,545 & 5,060 & $1,846,984$ & 872 \\
\hline 44 & Grand & Slack to Hwy 101 & Cal Poly area (e/o Santa Rosa) & Major Arterial & 0.29 & 14,681 & 4,218 & $1,539,573$ & 727 \\
\hline 45 & Grand & Hwy 101 to Mill & Downtown/Uptown & Minor Arterial & 0.17 & 9,346 & 1,563 & 570,487 & 269 \\
\hline 46 & Grand & Mill to Monterey & Downtown/Uptown & Minor Arterial & 0.08 & 8,314 & 696 & 254,034 & 120 \\
\hline 47 & Higuera & California to Johnson & Downtown/Uptown & Collector & 0.17 & 563 & 94 & 34,327 & 16 \\
\hline 48 & Higuera & Johnson to Santa Rosa & Downtown/Uptown & Major Arterial & 0.19 & 3,794 & 737 & 269,094 & 127 \\
\hline 49 & Higuera & Santa Rosa to Osos & Downtown/Uptown & Major Arterial & 0.10 & 8,306 & 801 & 292,260 & 138 \\
\hline 50 & Higuera & Osos to Chorro & Downtown/Uptown & Major Arterial & 0.15 & 9,518 & 1,406 & 513,215 & 242 \\
\hline 51 & Higuera & Chorro to Broad & Downtown/Uptown & Major Arterial & 0.12 & 10,331 & 1,250 & 456,354 & 215 \\
\hline 52 & Higuera & Broad to Nipomo & Downtown/Uptown & Major Arterial & 0.08 & 10,019 & 787 & 287,430 & 136 \\
\hline 53 & Higuera & Nipomo to Marsh & Downtown/Uptown & Major Arterial & 0.33 & 10,105 & 3,324 & $1,213,375$ & 573 \\
\hline 54 & Higuera & Marsh to Pismo/High & Downtown/Uptown & Major Arterial & 0.17 & 15,377 & 2,624 & 957,757 & 452 \\
\hline 55 & Higuera & Pismo/High to South & Broad/South & Major Arterial & 0.18 & 16,279 & 2,849 & $1,039,821$ & 491 \\
\hline 56 & Higuera & South to Madonna & Broad/South & Major Arterial & 0.07 & 29,587 & 2,023 & 738,358 & 347 \\
\hline 57 & Higuera & Madonna to Margarita & South Higuera corridor & Major Arterial & 0.82 & 16,644 & 13,649 & $4,982,009$ & 2,353 \\
\hline 58 & Higuera & Margarita to Prado & South Higuera corridor & Major Arterial & 0.17 & 15,047 & 2,568 & 937,203 & 444 \\
\hline 59 & Higuera & Prado to Granada & South Higuera corridor & Major Arterial & 0.27 & 17,315 & 4,706 & $1,717,645$ & 812 \\
\hline 60 & Higuera & Granada to Tank Farm & South Higuera corridor & Major Arterial & 0.34 & 17,964 & 6,076 & $2,217,908$ & 1,047 \\
\hline 61 & Higuera & Tank Farm to Suburban & South Higuera corridor & Major Arterial & 0.21 & 20,257 & 4,297 & $1,568,383$ & 740 \\
\hline 62 & Higuera & Suburban to LOVR & South Higuera corridor & Major Arterial & 0.19 & 21,282 & 4,119 & $1,503,565$ & 710 \\
\hline 63 & Higuera & LOVR to City Limits & South Higuera corridor & Major Arterial & 0.23 & 6,782 & 1,541 & 562,598 & 265 \\
\hline 64 & Industrial & Broad to Sacramento & Tank Farm/Broad & Minor Arterial & 0.29 & 4,244 & 1,243 & 453,863 & 214 \\
\hline
\end{tabular}


Table A.7: Community transportation sector emissions (2005) (cont'd)

\begin{tabular}{|c|c|c|c|c|c|c|c|c|c|}
\hline $\begin{array}{l}\text { Count } \\
\text { Location }\end{array}$ & Street & Segment & VMT Sub-area & $\begin{array}{c}\text { Street } \\
\text { Classification }\end{array}$ & $\begin{array}{l}\text { Segment } \\
\text { Length } \\
\text { (miles) }\end{array}$ & $\mathrm{ADT}$ & $\begin{array}{l}\text { Daily } \\
\text { VMT } \\
\text { (Length x } \\
\text { Volume) }\end{array}$ & $\begin{array}{c}\text { Annual VMT } \\
\text { (Daily VMT x } \\
\text { 365) }\end{array}$ & $\begin{array}{l}\text { Equivalent } \mathrm{CO}_{2} \\
\text { (metric tons) }\end{array}$ \\
\hline 65 & Laurel & Johnson to Augusta & Johnson/Orcutt & Minor Arterial & 0.12 & 7,068 & 859 & 313,683 & 148 \\
\hline 66 & Laurel & Augusta to Southwood & Johnson/Orcutt & Minor Arterial & 0.12 & 8,645 & 1,076 & 392,635 & 149 \\
\hline 67 & Laurel & Southwood Orcutt & Johnson/Orcutt & Minor Arterial & 0.30 & 8,676 & 2,641 & 963,817 & 455 \\
\hline 68 & LOVR & City Limits to Descanso & Madonna/LOVR area & Major Arterial & 0.37 & 23,020 & 8,585 & $3,133,358$ & 1,480 \\
\hline 69 & LOVR & Descanso to Prefumo Canyon & Madonna/LOVR area & Major Arterial & 0.12 & 27,893 & 3,302 & $1,205,131$ & 569 \\
\hline 70 & LOVR & Prefumo Canyon to Oceanaire & Madonna/LOVR area & Major Arterial & 0.36 & 27,093 & 9,683 & $3,534,174$ & 1,669 \\
\hline 71 & LOVR & Oceanaire to Royal Way & Madonna/LOVR area & Major Arterial & 0.12 & 26,606 & 3,270 & $1,193,667$ & 564 \\
\hline 72 & LOVR & Royal Way to Madonna & Madonna/LOVR area & Major Arterial & 0.17 & 29,573 & 5,007 & $1,827,645$ & 863 \\
\hline 73 & LOVR & Madonna to Froom Ranch & Madonna/LOVR area & Major Arterial & 0.49 & 23,589 & 11,513 & $4,202,260$ & 1,985 \\
\hline 74 & LOVR & Froom Ranch to Calle Joaquin & Madonna/LOVR area & Major Arterial & 0.34 & 24,970 & 8,366 & $3,053,552$ & 1,442 \\
\hline 75 & LOVR & SB 101 Ramp to NB 101 & Madonna/LOVR area & Major Arterial & 0.15 & 24,890 & 3,639 & $1,328,315$ & 627 \\
\hline 76 & LOVR & Calle Joaquin to SB US Ramp & Madonna/LOVR area & Major Arterial & 0.05 & 24,065 & 1,253 & 457,486 & 216 \\
\hline 77 & LOVR & NB US 101 to Higuera & South Higuera corridor & Major Arterial & 0.34 & 20,132 & 6,875 & $2,509,236$ & 1,185 \\
\hline 78 & Madonna & Tonnini to Los Osos Valley & Madonna/LOVR area & Collector & 0.08 & 5,872 & 445 & 162,370 & 77 \\
\hline 79 & Madonna & Los Osos Valley to Pereira & Madonna/LOVR area & Major Arterial & 0.08 & 19,937 & 1,495 & 545,775 & 258 \\
\hline 80 & Madonna & Pereira to Oceanaire & Madonna/LOVR area & Major Arterial & 0.34 & 21,651 & 7,291 & $2,661,146$ & 1,258 \\
\hline 81 & Madonna & Oceanaire to Dalidio & Madonna/LOVR area & Major Arterial & 0.29 & 24,735 & 7,289 & $2,660,605$ & 1,258 \\
\hline 82 & Madonna & Dalidio to El Mercado & Madonna/LOVR area & Major Arterial & 0.10 & 25,199 & 2,606 & 951,119 & 447 \\
\hline 83 & Madonna & El Mercado to US 101SB & Madonna/LOVR area & Major Arterial & 0.20 & 27,999 & 5,685 & $2,074,896$ & 980 \\
\hline 84 & Madonna & US $101 \mathrm{SB}$ to US $101 \mathrm{NB}$ & Madonna/LOVR area & Major Arterial & 0.19 & 32,871 & 6,319 & $2,306,417$ & 1,088 \\
\hline 85 & Madonna & US 101 NB Ramps to Higuera & Madonna/LOVR area & Major Arterial & 0.22 & 26,658 & 5,932 & $2,165,331$ & 1,025 \\
\hline 86 & Marsh & US 101 to Broad & Downtown/Uptown & Major Arterial & 0.45 & 12,273 & 5,544 & $2,023,476$ & 956 \\
\hline 87 & Marsh & Broad to Chorro & Downtown/Uptown & Major Arterial & 0.12 & 13,033 & 1,545 & 563,998 & 266 \\
\hline 88 & Marsh & Chorro to Osos & Downtown/Uptown & Major Arterial & 0.15 & 11,515 & 1,675 & 611,342 & 289 \\
\hline 89 & Marsh & Osos to Santa Rosa & Downtown/Uptown & Major Arterial & 0.10 & 12,609 & 1,280 & 467,202 & 221 \\
\hline 90 & Marsh & Santa Rosa to Johnson & Downtown/Uptown & Major Arterial & 0.19 & 7,476 & 1,437 & 524,559 & 248 \\
\hline 91 & Marsh & Johnson to California & Downtown/Uptown & Major Arterial & 0.19 & 3,608 & 674 & 245,925 & 116 \\
\hline 92 & Mill & Chorro to Osos & Downtown/Uptown & Collector & 0.15 & 3,358 & 490 & 178,976 & 85 \\
\hline 93 & Mill & Osos to Santa Rosa & Downtown/Uptown & Collector & 0.10 & 2,769 & 264 & 96,474 & 46 \\
\hline 94 & Mill & Santa Rosa to California & Downtown/Uptown & Collector & 0.38 & 3,276 & 1,248 & 455,649 & 215 \\
\hline 95 & Mill & California to Grand & Downtown/Uptown & Collector & 0.24 & 1,488 & 353 & 128,785 & 61 \\
\hline 96 & Monterey & Chorro to Osos & Downtown/Uptown & Minor Arterial & 0.14 & 4,368 & 630 & 230,089 & 109 \\
\hline
\end{tabular}


Table A.7: Community transportation sector emissions (2005) (cont'd)

\begin{tabular}{|c|c|c|c|c|c|c|c|c|c|}
\hline $\begin{array}{l}\text { Count } \\
\text { Location }\end{array}$ & Street & Segment & VMT Sub-area & $\begin{array}{c}\text { Street } \\
\text { Classification }\end{array}$ & $\begin{array}{l}\text { Segment } \\
\text { Length } \\
\text { (miles) }\end{array}$ & ADT & $\begin{array}{l}\text { Daily } \\
\text { VMT } \\
\text { (Length x } \\
\text { Volume) } \\
\end{array}$ & $\begin{array}{c}\text { Annual VMT } \\
\text { (Daily VMT x } \\
\text { 365) }\end{array}$ & $\begin{array}{c}\text { Equivalent } \mathrm{CO}_{2} \\
\text { (metric tons) }\end{array}$ \\
\hline 97 & Monterey & Osos to Santa Rosa & Downtown/Uptown & Minor Arterial & 0.09 & 5,892 & 559 & 204,061 & 96 \\
\hline 98 & Monterey & Santa Rosa to Johnson & Downtown/Uptown & Minor Arterial & 0.20 & 11,854 & 2,342 & 854,689 & 404 \\
\hline 99 & Monterey & Johnson to California & Downtown/Uptown & Minor Arterial & 0.19 & 13,785 & 2,566 & 936,740 & 442 \\
\hline 100 & Monterey & California to Grand & Downtown/Uptown & Minor Arterial & 0.24 & 14,869 & 3,517 & $1,283,817$ & 606 \\
\hline 101 & Monterey & Grand to Hwy 101 & Downtown/Uptown & Collector & 0.23 & 9,527 & 2,221 & 810,724 & 383 \\
\hline 102 & Johnson & Mill to Monterey & Downtown/Uptown & Collector & 0.15 & 3,962 & 581 & 211,990 & 100 \\
\hline 103 & Johnson & Monterey to Marsh & Downtown/Uptown & Minor Arterial & 0.11 & 11,537 & 1,304 & 476,131 & 225 \\
\hline 104 & Johnson & Marsh to Pismo & Downtown/Uptown & Minor Arterial & 0.13 & 13,716 & 1,847 & 674,149 & 318 \\
\hline 105 & Johnson & Pismo to San Luis Drive & Downtown/Uptown & Minor Arterial & 0.18 & 15,110 & 2,782 & $1,015,289$ & 479 \\
\hline 106 & Johnson & San Luis Drive to Ella & Johnson/Orcutt & Major Arterial & 0.26 & 19,994 & 5,203 & $1,899,089$ & 897 \\
\hline 107 & Johnson & Ella to Bishop & Johnson/Orcutt & Major Arterial & 0.26 & 17,034 & 4,400 & $1,606,164$ & 703 \\
\hline 108 & Johnson & Bishop to Sydney & Johnson/Orcutt & Major Arterial & 0.24 & 15,789 & 3,723 & $1,358,886$ & 642 \\
\hline 109 & Johnson & Sydney to Laurel & Johnson/Orcutt & Major Arterial & 0.39 & 15,655 & 6,140 & $2,241,259$ & 1,058 \\
\hline 110 & Johnson & Laurel to Southwood & Johnson/Orcutt & Major Arterial & 0.29 & 15,277 & 4,438 & $1,620,027$ & 765 \\
\hline 111 & Johnson & Southwood to Orcutt & Johnson/Orcutt & Major Arterial & 0.24 & 14,682 & 3,504 & $1,278,836$ & 604 \\
\hline 112 & Aero Loop & W/O Broad & Tank Farm/Broad & Collector & 0.29 & 2,282 & 666 & 242,938 & 115 \\
\hline 113 & Aero Vista & W/O Broad & Tank Farm/Broad & Collector & 0.11 & 3,076 & 332 & 121,205 & 57 \\
\hline 114 & Augusta & Sydney to Laurel & Johnson/Orcutt & Collector & 0.45 & 2,590 & 1,162 & 423,975 & 200 \\
\hline 115 & Buchon & High to Broad & Downtown/Uptown & Collector & 0.42 & 1,403 & 586 & 214,052 & 101 \\
\hline 116 & Buchon & Broad to Chorro & Downtown/Uptown & Collector & 0.12 & 2,118 & 254 & 92,827 & 44 \\
\hline 117 & Buchon & Chorro to Osos & Downtown/Uptown & Collector & 0.14 & 2,131 & 304 & 110,927 & 53 \\
\hline 118 & Buchon & Osos to Santa Rosa & Downtown/Uptown & Collector & 0.10 & 5,466 & 525 & 191,574 & 90 \\
\hline 119 & Buchon & Santa Rosa to Johnson & Downtown/Uptown & Collector & 0.21 & 4,727 & 995 & 363,043 & 171 \\
\hline 120 & High & Higuera to Buchon & Downtown/Uptown & Collector & 0.12 & 5,582 & 652 & 238,086 & 113 \\
\hline 121 & High & Buchon to Broad & Downtown/Uptown & Collector & 0.52 & 2,436 & 1,262 & 460,568 & 218 \\
\hline 122 & Highland & Patricia to Ferrini & Santa Rosa/Foothill & Collector & 0.51 & 6,956 & 3,581 & $1,306,977$ & 617 \\
\hline 123 & Highland & Santa Rosa to Mt. Bishop & Cal Poly area (e/o Santa Rosa) & Collector & 0.46 & 9,436 & 4,330 & $1,580,521$ & 747 \\
\hline 124 & La Entrada & Foothill to Ramona & Santa Rosa/Foothill & Collector & 0.08 & 1,221 & 92 & 33,678 & 16 \\
\hline 125 & Margarita & Higuera to City Limits & South Higuera corridor & Collector & 0.47 & 453 & 211 & 77,130 & 36 \\
\hline 126 & Meinecke & Chorro to Santa Rosa & Santa Rosa/Foothill & Collector & 0.13 & 1,393 & 182 & 66,541 & 31 \\
\hline 127 & Murray & Chorro to Santa Rosa & Santa Rosa/Foothill & Collector & 0.16 & 2,063 & 332 & 121,221 & 57 \\
\hline 128 & Oceanaire & LOVR to Balboa & Madonna/LOVR area & Collector & 0.34 & 1,759 & 591 & 215,592 & 102 \\
\hline
\end{tabular}


Table A.7: Community transportation sector emissions (2005) (cont'd)

\begin{tabular}{|c|c|c|c|c|c|c|c|c|c|}
\hline $\begin{array}{l}\text { Count } \\
\text { Location }\end{array}$ & Street & Segment & VMT Sub-area & $\begin{array}{c}\text { Street } \\
\text { Classification }\end{array}$ & $\begin{array}{l}\text { Segment } \\
\text { Length } \\
\text { (miles) }\end{array}$ & ADT & $\begin{array}{l}\text { Daily } \\
\text { VMT } \\
\text { (Length x } \\
\text { Volume) }\end{array}$ & $\begin{array}{c}\text { Annual VMT } \\
\text { (Daily VMT x } \\
\text { 365) }\end{array}$ & $\begin{array}{l}\text { Equivalent } \mathrm{CO}_{2} \\
\text { (metric tons) }\end{array}$ \\
\hline 129 & Oceanaire & Balboa to Lake View & Madonna/LOVR area & Collector & 0.26 & 1,561 & 401 & 146,218 & 69 \\
\hline 130 & Oceanaire & Lake View to Madonna & Madonna/LOVR area & Collector & 0.25 & 2,502 & 623 & 227,443 & 107 \\
\hline 131 & Oceanaire & Madonna to Oceanaire & Madonna/LOVR area & Collector & 0.34 & 626 & 211 & 77,115 & 36 \\
\hline 132 & Olive & US 101 SB Ramp to Santa Rosa & Santa Rosa/Foothill & Collector & 0.14 & 21,519 & 3,093 & $1,129,075$ & 534 \\
\hline 133 & Orcutt & Broad to Laurel & Johnson/Orcutt & Major Arterial & 0.38 & 14,696 & 5,569 & $2,032,849$ & 960 \\
\hline 134 & Orcutt & Laurel to Johnson & Johnson/Orcutt & Major Arterial & 0.42 & 2,569 & 1,087 & 396,740 & 187 \\
\hline 135 & Orcutt & Johnson to Tank Farm & Tank Farm/Broad & County Highway & 0.97 & 7,981 & 7,715 & $2,815,963$ & 1,330 \\
\hline 136 & Orcutt & Tank Farm to City Line & Tank Farm/Broad & County Highway & 0.43 & 3,523 & 1,520 & 554,786 & 262 \\
\hline 137 & Osos & US 101 to Palm & Downtown/Uptown & Minor Arterial & 0.23 & 2,920 & 664 & 242,429 & 114 \\
\hline 138 & Osos & Palm to Monterey & Downtown/Uptown & Minor Arterial & 0.07 & 3,727 & 274 & 99,965 & 47 \\
\hline 139 & Osos & Monterey to Higuera & Downtown/Uptown & Minor Arterial & 0.06 & 4,608 & 271 & 98,749 & 47 \\
\hline 140 & Osos & Higuera to Marsh & Downtown/Uptown & Minor Arterial & 0.07 & 5,807 & 378 & 138,092 & 65 \\
\hline 141 & Osos & Marsh to Pismo & Downtown/Uptown & Minor Arterial & 0.13 & 8,398 & 1,109 & 404,639 & 191 \\
\hline 142 & Osos & Pismo to Leff & Downtown/Uptown & Minor Arterial & 0.20 & 11,288 & 2,223 & 811,539 & 383 \\
\hline 143 & Palm & Nipomo to Chorro & Downtown/Uptown & Collector & 0.20 & 2,333 & 467 & 170,309 & 80 \\
\hline 144 & Palm & Chorro to Osos & Downtown/Uptown & Collector & 0.14 & 4,275 & 610 & 222,531 & 19 \\
\hline 145 & Palm & Osos to Santa Rosa & Downtown/Uptown & Collector & 0.10 & 2,528 & 245 & 89,301 & 9 \\
\hline 146 & Pismo & Higuera to Broad & Downtown/Uptown & Minor Arterial & 0.51 & 2,669 & 1,374 & 501,668 & 237 \\
\hline 147 & Pismo & Broad to Osos & Downtown/Uptown & Minor Arterial & 0.26 & 3,622 & 939 & 342,776 & 162 \\
\hline 148 & Pismo & Osos to Santa Rosa & Downtown/Uptown & Minor Arterial & 0.09 & 6,181 & 583 & 212,788 & 100 \\
\hline 149 & Pismo & Santa Rosa to Johnson & Downtown/Uptown & Minor Arterial & 0.21 & 4,165 & 865 & 315,850 & 149 \\
\hline 150 & Prado & US 101 to Higuera & South Higuera corridor & Minor Arterial & 0.32 & 7,271 & 2,351 & 857,999 & 405 \\
\hline 151 & Prado & Higuera to City Line & South Higuera corridor & Minor Arterial & 0.48 & 2,894 & 1,402 & 511,750 & 241 \\
\hline 152 & Prefumo Canyon & Del Rio to Los Osos Valley & Madonna/LOVR area & Collector & 0.18 & 3,075 & 540 & 197,266 & 93 \\
\hline 153 & Ramona & Tassajara to Broad & Santa Rosa/Foothill & Collector & 0.36 & 3,193 & 1,145 & 418,059 & 198 \\
\hline 154 & Tassajara & Foothill to Ramona & Santa Rosa/Foothill & Collector & 0.08 & 1,906 & 153 & 55,734 & 26 \\
\hline 155 & Sacramento & Capitolio to Industrial & Tank Farm/Broad & Collector & 0.39 & 2,481 & 969 & 353,651 & 167 \\
\hline 156 & San Luis & California to Johnson & Downtown/Uptown & Major Arterial & 0.33 & 11,662 & 3,861 & $1,409,203$ & 665 \\
\hline 157 & Santa Barbara & Leff to High & Broad/South & Minor Arterial & 0.30 & 14,392 & 4,323 & $1,577,914$ & 744 \\
\hline 158 & Santa Barbara & High to Broad & Broad/South & Minor Arterial & 0.18 & 13,940 & 2,469 & 901,018 & 425 \\
\hline 159 & Santa Rosa & Highland to City Line & Santa Rosa/Foothill & County Highway & 0.07 & 30,599 & 2,046 & 746,691 & 353 \\
\hline 160 & Santa Rosa & Highland to Foothill & Santa Rosa/Foothill & Major Arterial & 0.38 & 31,087 & 11,899 & $4,343,142$ & 2,052 \\
\hline
\end{tabular}


Table A.7: Community transportation sector emissions (2005) (cont'd)

\begin{tabular}{|c|c|c|c|c|c|c|c|c|c|}
\hline $\begin{array}{l}\text { Count } \\
\text { Location }\end{array}$ & Street & Segment & VMT Sub-area & $\begin{array}{c}\text { Street } \\
\text { Classification }\end{array}$ & $\begin{array}{l}\text { Segment } \\
\text { Length } \\
\text { (miles) }\end{array}$ & ADT & $\begin{array}{l}\text { Daily } \\
\text { VMT } \\
\text { (Length x } \\
\text { Volume) } \\
\end{array}$ & $\begin{array}{c}\text { Annual VMT } \\
\text { (Daily VMT x } \\
\text { 365) }\end{array}$ & $\begin{array}{c}\text { Equivalent } \mathrm{CO}_{2} \\
\text { (metric tons) }\end{array}$ \\
\hline 161 & Santa Rosa & Foothill to US 101 & Santa Rosa/Foothill & Major Arterial & 0.57 & 38,197 & 21,876 & 7,984,909 & 3,773 \\
\hline 162 & Santa Rosa & US 101 to Walnut & Downtown/Uptown & Major Arterial & 0.06 & 23,765 & 1,535 & 560,210 & 266 \\
\hline 163 & Santa Rosa & Walnut to Palm & Downtown/Uptown & Major Arterial & 0.20 & 21,080 & 4,288 & $1,565,070$ & 738 \\
\hline 164 & Santa Rosa & Palm to Monterey & Downtown/Uptown & Major Arterial & 0.08 & 21,388 & 1,604 & 585,497 & 277 \\
\hline 165 & Santa Rosa & Monterey to Higuera & Downtown/Uptown & Major Arterial & 0.06 & 21,563 & 1,274 & 465,075 & 219 \\
\hline 166 & Santa Rosa & Higuera to Marsh & Downtown/Uptown & Major Arterial & 0.06 & 17,777 & 1,114 & 406,767 & 193 \\
\hline 167 & Santa Rosa & Marsh to Pismo & Downtown/Uptown & Major Arterial & 0.13 & 7,983 & 1,033 & 376,917 & 178 \\
\hline 168 & Santa Rosa & Pismo to Buchon & Downtown/Uptown & Major Arterial & 0.07 & 5,134 & 345 & 125,992 & 59 \\
\hline 169 & Santa Rosa & Buchon to Leff & Downtown/Uptown & Minor Arterial & 0.13 & 2,346 & 302 & 110,118 & 52 \\
\hline 170 & South Street & Higuera to Broad & Broad/South & Major Arterial & 0.78 & 17,458 & 13,570 & $4,952,914$ & 2,338 \\
\hline 171 & Tank Farm & Higuera to Santa Fe & South Higuera corridor & Major Arterial & 1.51 & 19,835 & 29,910 & $10,917,252$ & 5,156 \\
\hline 172 & Tank Farm & Santa Fe to Broad & Tank Farm/Broad & Major Arterial & 0.25 & 19,410 & 4,941 & $1,803,365$ & 853 \\
\hline 173 & Tank Farm & Broad to UPRR & Tank Farm/Broad & Major Arterial & 0.48 & 10,306 & 4,897 & $1,787,515$ & 844 \\
\hline 174 & Tank Farm & UPRR to Orcutt & Tank Farm/Broad & Major Arterial & 0.58 & 8,386 & 4,884 & $1,782,621$ & 841 \\
\hline 175 & Walnut & Osos to Santa Rosa & Downtown/Uptown & Collector & 0.10 & 4,142 & 402 & 146,602 & 69 \\
\hline 176 & Walnut & Santa Rosa to Toro & Downtown/Uptown & Collector & 0.09 & 8,597 & 803 & 292,990 & 138 \\
\hline CT01 & Hwy 101 & S/O Los Osos Valley & U.S. 101 (LOVR to Monterey) & Highway & & 62,000 & & & 0 \\
\hline CT02 & Hwy 101 & Los Osos Valley to Prado & U.S. 101 (LOVR to Monterey) & Highway & 0.79 & 62,000 & 49,201 & $17,958,277$ & 8,443 \\
\hline CT03 & Hwy 101 & Prado to Madonna & U.S. 101 (LOVR to Monterey) & Highway & 0.66 & 54,000 & 35,826 & $13,076,540$ & 6,143 \\
\hline CT04 & Hwy 101 & Madonna to Marsh & U.S. 101 (LOVR to Monterey) & Highway & 0.57 & 54,000 & 30,610 & $11,172,733$ & 5,306 \\
\hline CT05 & Hwy 101 & Marsh to Broad & U.S. 101 (LOVR to Monterey) & Highway & 0.76 & 70,000 & 53,534 & $19,539,943$ & 9,170 \\
\hline CT06 & Hwy 101 & Broad to Osos & U.S. 101 (LOVR to Monterey) & Highway & 0.21 & 65,000 & 13,776 & $5,028,082$ & 2,353 \\
\hline СТ07 & Hwy 101 & Osos to Toro & U.S. 101 (LOVR to Monterey) & Highway & 0.23 & 65,000 & 14,637 & $5,342,618$ & 2,577 \\
\hline CT08 & Hwy 101 & Toro to California & U.S. 101 (LOVR to Monterey) & Highway & 0.26 & 55,000 & 14,188 & $5,178,438$ & 2,465 \\
\hline CT09 & Hwy 101 & California to Grand & U.S. 101 (LOVR to Monterey) & Highway & 0.26 & 43,000 & 11,173 & $4,078,322$ & 1,927 \\
\hline CT10 & Hwy 101 & Grand to Monterey & U.S. 101 (LOVR to Monterey) & Highway & 0.37 & 35,000 & 13,112 & $4,785,786$ & 2,232 \\
\hline CT11 & Hwy 101 & N/O Monterey & U.S. 101 (LOVR to California) & Highway & & 40,000 & & & 0 \\
\hline CT12 & Hwy 101 / LOVR & $\mathrm{NB}$ on & U.S. 101 on- and off-ramps & Highway Ramp & 0.11 & 3,650 & 417 & 152,149 & 72 \\
\hline CT13 & Hwy 101 / LOVR & NB off & U.S. 101 on- and off-ramps & Highway Ramp & 0.18 & 6,550 & 1,152 & 420,645 & 199 \\
\hline CT14 & Hwy 101 / LOVR & SB on & U.S. 101 on- and off-ramps & Highway Ramp & 0.20 & 6,650 & 1,305 & 476,256 & 225 \\
\hline CT15 & Hwy 101 / LOVR & SB off & U.S. 101 on- and off-ramps & Highway Ramp & 0.07 & 5,450 & 355 & 129,603 & 61 \\
\hline CT16 & Hwy 101 / Prado & NB on & U.S. 101 on- and off-ramps & Highway Ramp & 0.05 & 1,450 & 78 & 28,567 & 13 \\
\hline CT17 & Hwy 101 / Prado & NB off & U.S. 101 on- and off-ramps & Highway Ramp & 0.15 & 4,400 & 653 & 238,467 & 112 \\
\hline
\end{tabular}


Table A.7: Community transportation sector emissions (2005) (cont'd)

\begin{tabular}{|c|c|c|c|c|c|c|c|c|c|}
\hline $\begin{array}{l}\text { Count } \\
\text { Location }\end{array}$ & Street & Segment & VMT Sub-area & $\begin{array}{c}\text { Street } \\
\text { Classification }\end{array}$ & $\begin{array}{l}\text { Segment } \\
\text { Length } \\
\text { (miles) }\end{array}$ & $\mathrm{ADT}$ & $\begin{array}{l}\text { Daily } \\
\text { VMT } \\
\text { (Length x } \\
\text { Volume) } \\
\end{array}$ & $\begin{array}{c}\text { Annual VMT } \\
\text { (Daily VMT x } \\
365 \text { ) }\end{array}$ & $\begin{array}{c}\text { Equivalent } \mathrm{CO}_{2} \\
\text { (metric tons) }\end{array}$ \\
\hline CT18 & Hwy 101 / Madonna & $\mathrm{NB}$ on & U.S. 101 on- and off-ramps & Highway Ramp & 0.12 & 9,600 & 1,131 & 412,782 & 195 \\
\hline CT19 & Hwy 101 / Madonna & NB off & U.S. 101 on- and off-ramps & Highway Ramp & 0.14 & 4,225 & 599 & 218,760 & 103 \\
\hline CT20 & Hwy 101 / Madonna & SB on & U.S. 101 on- and off-ramps & Highway Ramp & 0.30 & 4,450 & 1,332 & 486,352 & 229 \\
\hline CT21 & Hwy 101 / Madonna & SB off & U.S. 101 on- and off-ramps & Highway Ramp & 0.16 & 10,925 & 1,788 & 652,520 & 309 \\
\hline CT22 & Hwy 101 / Higuera & $\mathrm{NB}$ on & U.S. 101 on- and off-ramps & Highway Ramp & 0.09 & 5,650 & 489 & 178,494 & 85 \\
\hline CT23 & Hwy 101 / Higuera & NB off & U.S. 101 on- and off-ramps & Highway Ramp & 0.17 & 5,600 & 942 & 343,764 & 162 \\
\hline CT24 & Hwy 101 / Higuera & SB on & U.S. 101 on- and off-ramps & Highway Ramp & 0.23 & 5,400 & 1,255 & 458,034 & 216 \\
\hline CT25 & Hwy 101 / Higuera & SB off & U.S. 101 on- and off-ramps & Highway Ramp & 0.22 & 3,200 & 690 & 251,961 & 119 \\
\hline CT26 & Hwy 101 / Broad & NB on & U.S. 101 on- and off-ramps & Highway Ramp & 0.08 & 1,350 & 110 & 40,036 & 19 \\
\hline CT27 & Hwy 101 / Broad & NB off & U.S. 101 on- and off-ramps & Highway Ramp & 0.05 & 1,850 & 88 & 32,100 & 15 \\
\hline CT28 & Hwy 101 / Broad & SB on & U.S. 101 on- and off-ramps & Highway Ramp & 0.06 & 2,700 & 168 & 61,220 & 29 \\
\hline CT29 & Hwy 101 / Broad & SB off & U.S. 101 on- and off-ramps & Highway Ramp & 0.06 & 1,500 & 95 & 34,530 & 16 \\
\hline CT30 & Hwy 101 / Osos & NB on & U.S. 101 on- and off-ramps & Highway Ramp & 0.08 & 2,200 & 170 & 62,050 & 29 \\
\hline CT31 & Hwy 101 / Osos & NB off & U.S. 101 on- and off-ramps & Highway Ramp & 0.06 & 2,800 & 170 & 61,939 & 29 \\
\hline CT32 & Hwy 101 / Osos & SB on & U.S. 101 on- and off-ramps & Highway Ramp & - & 8,900 & - & - & 0 \\
\hline CT33 & Hwy 101 / Osos & SB off & U.S. 101 on- and off-ramps & Highway Ramp & 0.07 & 950 & 68 & 24,824 & 12 \\
\hline CT34 & Hwy 101 / Olive & SB on & U.S. 101 on- and off-ramps & Highway Ramp & 0.21 & 2,200 & 466 & 170,029 & 80 \\
\hline CT35 & Hwy 101 / Toro & NB on & U.S. 101 on- and off-ramps & Highway Ramp & 0.11 & 1,200 & 128 & 46,786 & 22 \\
\hline CT36 & Hwy 101 / Toro & NB off & U.S. 101 on- and off-ramps & Highway Ramp & 0.06 & 8,800 & 557 & 203,183 & 96 \\
\hline CT37 & Hwy 101 / California & $\mathrm{NB}$ on & U.S. 101 on- and off-ramps & Highway Ramp & 0.11 & 2,075 & 238 & 86,926 & 41 \\
\hline CT38 & Hwy 101 / California & NB off & U.S. 101 on- and off-ramps & Highway Ramp & 0.11 & 4,600 & 501 & 182,846 & 86 \\
\hline CT39 & Hwy 101 / California & SB on & U.S. 101 on- and off-ramps & Highway Ramp & 0.06 & 2,775 & 168 & 61,195 & 29 \\
\hline CT40 & Hwy 101 / California & SB off & U.S. 101 on- and off-ramps & Highway Ramp & 0.08 & 3,700 & 310 & 113,053 & 54 \\
\hline CT41 & Hwy 101 / Grand & NB off & U.S. 101 on- and off-ramps & Highway Ramp & 0.13 & 3,450 & 438 & 159,791 & 76 \\
\hline CT42 & Hwy 101 / Grand & SB on & U.S. 101 on- and off-ramps & Highway Ramp & 0.12 & 4,775 & 596 & 217,529 & 103 \\
\hline CT43 & Hwy 101 / Monterey & NB on & U.S. 101 on- and off-ramps & Highway Ramp & 0.09 & & & & 0 \\
\hline CT44 & Hwy 101 / Monterey & NB off & U.S. 101 on- and off-ramps & Highway Ramp & 0.09 & 900 & 78 & 28,370 & 13 \\
\hline CT45 & Hwy 101 / Monterey & SB on & U.S. 101 on- and off-ramps & Highway Ramp & -- & 2,150 & -- & - & 47 \\
\hline CT46 & Hwy 101 / Monterey & SB off & U.S. 101 on- and off-ramps & Highway Ramp & 0.08 & 3,600 & 272 & 99,297 & 0 \\
\hline \multicolumn{5}{|l|}{ Totals } & 49.86 & 12,713 & 768,239 & $280,407,300$ & 132,137 \\
\hline
\end{tabular}

Source: City of San Luis Obispo, Public Works Department, Transportation Division (City-wide traffic counts program, 2005-06) 
Table A. 8 provides a summary of the results from the City's traffic counts program in terms of daily and annual VMT and the emissions of each VMT sub-area. The Downtown/Uptown and Madonna/LOVR sub-areas each generated over 16,000 $\mathrm{MTCO}_{2} \mathrm{e}$, although the emissions occurred over five road-miles in the Madonna/LOVR sub-area as opposed to over nearly thirteen miles of roadway miles in the Downtown/Uptown sub-area. Three of the sub-areas (Tank Farm/Broad, Santa Rosa/Foothill, and South Higuera) each generated between 11,000 and 14,000 $\mathrm{MTCO}_{2} \mathrm{e}$ emissions, all over a similar distance of road-miles.

Table A.8: Transportation sector - summary of VMT \& emissions by sub-area (2005-2006)

\begin{tabular}{|l|r|r|r|r|r|}
\hline \multicolumn{1}{|c|}{ VMT sub-area } & $\begin{array}{c}\text { Road- } \\
\text { miles }\end{array}$ & Daily VMT & \multicolumn{1}{|c|}{$\begin{array}{c}\text { Annual } \\
\text { VMT } \\
\text { (in millions) }\end{array}$} & $\begin{array}{c}\text { Equivalent } \\
\text { CO }_{2} \\
\text { (metric tons) }\end{array}$ & $\begin{array}{c}\text { Energy } \\
\text { (MMBtu) }\end{array}$ \\
\hline Broad/South & 2.68 & 49,531 & 18.1 & 8,534 & 118,829 \\
\hline Cal Poly area (e/o Santa Rosa) & 1.46 & 18,212 & 6.6 & 3,140 & 43,713 \\
\hline Downtown/Uptown & 12.78 & 95,653 & 34.9 & 16,365 & 227,898 \\
\hline Johnson/Orcutt & 3.48 & 39,803 & 14.5 & 6,768 & 94,241 \\
\hline Madonna/LOVR area & 5.02 & 94,046 & 34.3 & 16,213 & 225,757 \\
\hline Santa Rosa/Foothill & 5.37 & 72,684 & 26.5 & 12,533 & 174,531 \\
\hline South Higuera corridor & 5.36 & 77,706 & 28.4 & 13,394 & 186,511 \\
\hline Tank Farm/Broad & 5.66 & 67,743 & 24.7 & 11,678 & 162,605 \\
\hline U.S. 101 (LOVR to Monterey) ${ }^{(\mathrm{b})}$ & 4.12 & 236,057 & 86.2 & 40,616 & 565,542 \\
\hline U.S. 101 on- and off-ramps & 3.89 & 16,806 & 6.1 & 2,896 & 40,344 \\
\hline Total (all sub-areas) & 49.82 & 768,241 & 280.4 & 132,137 & $1,839,971$ \\
\hline
\end{tabular}

Source: City of San Luis Obispo, Public Works Department, Transportation Division (City-wide Traffic Counts Program, 2005-06) Note:

(a) All vehicle mileage is counted along U.S. 101 from Los Osos Valley Road to Monterey Street interchanges.

Table A.9 provides greater insight into the different levels of vehicle-miles of travel in the eight subareas (and U.S. 101-related VMT), by showing daily and annual VMT per lane-mile in each subarea, as well as vehicle emissions per lane-mile ${ }^{79}$. The highest level of daily and annual VMT per lane-mile occurs along U.S. 101 (12,257 DVMT per lane-mile; 4.47 million annual VMT per lane-

\footnotetext{
79 Table A.9 provides roadway figures in terms of total road-miles, without taking into account that some roadways in the community are four-lane facilities (i.e., Los Osos Valley Road or most of Broad Street), while many roadways are two-lane facilities (i.e., Osos Street, Monterey Street).
} 
mile). Additionally, the highest level of emissions per lane-mile occurs on U.S. 101 (2,109 $\mathrm{MTCO}_{2} \mathrm{e}$ per lane-mile, which is more than double the amount in the Broad/South sub-area). Among the local roadways in the community, the highest levels of daily and annual VMT per lane-mile occur in Broad/South, Madonna/LOVR, and Santa Rosa/Foothill subareas. Local traffic in each of these subareas generates more than $900 \mathrm{MTCO}_{2} \mathrm{e}$ emissions per lane-mile. It is important to point out that the local traffic in the Downtown/Uptown sub-area generates only $556 \mathrm{MTCO}_{2} \mathrm{e}$ emissions per lanemile, whereas the average of all the sub-areas, including the traffic accounted for on U.S. 101, is 952 $\mathrm{MTCO}_{2} \mathrm{e}$ emissions per lane-mile.

Table A.9: Transportation sector - emissions per lane-mile by sub-area (2005-2006)

\begin{tabular}{|c|c|c|c|c|c|c|c|}
\hline VMT sub-area & $\begin{array}{l}\text { Lane- } \\
\text { miles }\end{array}$ & $\begin{array}{l}\text { Daily } \\
\text { VMT }\end{array}$ & $\begin{array}{l}\text { Annual } \\
\text { VMT } \\
\text { (in millions) }\end{array}$ & $\begin{array}{l}\text { Equivalent } \\
\qquad \mathrm{CO}_{2} \\
\text { (metric tons) }\end{array}$ & $\begin{array}{c}\text { Daily } \\
\text { VMT per } \\
\text { lane-mile }\end{array}$ & $\begin{array}{l}\text { Annual } \\
\text { VMT per } \\
\text { lane-mile } \\
\text { (in millions) }\end{array}$ & $\begin{array}{c}\text { Equivalent } \\
\mathrm{CO}_{2} \text { per } \\
\text { lane-mile } \\
\text { (metric tons) }\end{array}$ \\
\hline Broad/South & 8.64 & 49,531 & 18.1 & 8,534 & 5,734 & 2.09 & 988 \\
\hline Cal Poly area (e/o Santa Rosa) & 4.01 & 18,212 & 6.6 & 3,140 & 4,544 & 1.66 & 784 \\
\hline Downtown/Uptown & 29.42 & 95,653 & 34.9 & 16,365 & 3,251 & 1.19 & 556 \\
\hline Johnson/Orcutt & 10.35 & 39,803 & 14.5 & 6,768 & 3,847 & 1.40 & 654 \\
\hline Madonna/LOVR area & 17.66 & 94,046 & 34.3 & 16,213 & 5,326 & 1.94 & 918 \\
\hline Santa Rosa/Foothill & 13.93 & 72,684 & 26.5 & 12,533 & 5,220 & 1.91 & 900 \\
\hline South Higuera corridor & 15.41 & 77,706 & 28.4 & 13,394 & 5,042 & 1.84 & 869 \\
\hline Tank Farm/Broad area & 16.16 & 67,743 & 24.7 & 11,678 & 4,191 & 1.53 & 723 \\
\hline U.S. 101 (LOVR to Monterey) ${ }^{(\mathrm{a})}$ & 19.26 & 236,057 & 86.2 & 40,616 & 12,257 & 4.47 & 2,109 \\
\hline U.S. 101 on- and off-ramps & 3.89 & 16,806 & 6.1 & 2,896 & 4,318 & 1.58 & 744 \\
\hline Total (all sub-areas) & 138.73 & 768,241 & 280.3 & 132,137 & & & \\
\hline Average & & & & & 5,538 & 2.02 & 952 \\
\hline
\end{tabular}

Source: City of San Luis Obispo, Public Works Department, Transportation Division (City-wide Traffic Counts Program, 2005-06) Note:

(a) All vehicle mileage is counted along U.S. 101 from Los Osos Valley Road to Monterey Street interchanges. 


\section{Appendix $B-$ Electricity and natural gas coefficients}

The default electricity and natural gas coefficients used by the CACP software are national averages. To make the inventory more accurate and representative of the community's real impact on climate change, specific coefficient sets for California were obtained. The author of this report collaborated with the authors of the County of San Luis Obispo Community-Wide and County Government Operations Baseline Greenhouse Gas Emissions Inventory to identify the appropriate coefficient set for use in this 2005 emissions inventory. Sources and coefficient values are summarized in the tables below.

Table B.1: Average grid electricity set used in CACP software

\begin{tabular}{|c|c|c|c|c|}
\hline Average grid electricity set & Unit & $\mathrm{CO}_{2}$ & $\mathrm{~N}_{2} \mathrm{O}$ & $\mathrm{CH}_{4}$ \\
\hline PG\&E California, 2005 & lbs / MWh & 489.16 & 0.011 & 0.029 \\
\hline
\end{tabular}

Source: California Air Resources Board et al., Local Government Operations Protocol (Table G.5: Utility-Specific Verified Electricity $\mathrm{CO}_{2}$ Emission Factors (2000-2006)).

Table B.2: Marginal grid electricity used in CACP software

\begin{tabular}{|c|}
\hline Marginal grid electricity set \\
\hline $13-$ Western Systems Coordinating Council/CNV \\
Source: Coefficient set provided by CACP.
\end{tabular}

Table B.3: Average CHP set used in CACP software

\begin{tabular}{|c|}
\hline Average CHP heat set \\
\hline USA total \\
\hline
\end{tabular}

Source: Coefficient set provided by CACP.

Table B.4: California coefficients for natural gas used in CACP software

\begin{tabular}{|l|l|l|l|l|}
\hline \multicolumn{1}{|c|}{ RCI average set } & \multicolumn{1}{c|}{ Sector } & Units & $\mathrm{N}_{2} \mathrm{O}$ & $\mathrm{CH}_{4}$ \\
\hline California Coefficients for Natural Gas \\
\hline Natural Gas & Commercial & $\mathrm{kg} / \mathrm{MMBtu}$ & 0.0001 & 0.0059 \\
\hline Natural Gas & Industrial & $\mathrm{kg} / \mathrm{MMBtu}$ & 0.0001 & 0.0059 \\
\hline Natural Gas & Residential & $\mathrm{kg} / \mathrm{MMBtu}$ & 0.0001 & 0.0059 \\
\hline
\end{tabular}

Source: The "California Coefficients for Natural Gas" coefficient set is based on a PG\&E CO 2 emissions factor of 53.05 kg/MMBtu of delivered natural gas, certified by the California Climate Action Registry and the CEC, and was reported to ICLEI in December 2007 by Jasmin Ansar (PG\&E). The weighted U.S. average $\mathrm{CO}_{2}$ emission factor for natural gas combustion is $53.06 \mathrm{~kg} / \mathrm{MMBtu}$, as noted in the Local Government Operations Protocol (Table G.1: Default Factors for Calculating $\mathrm{CO}_{2}$ Emission Factors from Fossil Fuel Combustion). 


\section{Appendix C-Quantification methodology of municipal emissions}

\section{C.1 Quantify emissions from electricity}

Many of the City's facilities use purchased electricity, which is a Scope 2 emission, an indirect emission. The generation of electricity through the combustion of fossil fuels typically yields $\mathrm{CO}_{2}$, and to a smaller extent, $\mathrm{N}_{2} \mathrm{O}$ and $\mathrm{CH}_{4}$. Under the Local Government Operations Protocol (Protocol), this inventory reports Scope 2 emissions occurring in the following sectors:

- Streetlights and traffic signals;

- Water delivery facilities;

- Wastewater facilities; and

- All other buildings and facilities not included in the sectors above.

Reporting these sectors separately facilitates a more useful comparison of a local government's emissions over time.

Under the Protocol, the recommended approach to calculate Scope 2 emissions from electricity use includes the following three steps:

1) Determine annual electricity use from each facility;

2) Select the appropriate emission factors that apply to the electricity used; and

3) Determine your total annual emissions in metric tons of carbon dioxide equivalents.

\section{Step 1: Determine annual electricity consumption.}

Monthly electricity bills provide the number of kilowatt-hours of electricity consumed for each facility. Monthly bills were aggregated to determine the annual electricity use for each facility. 


\section{Step 2: Select the appropriate emission factors.}

An electricity emission factor represents the amount of greenhouse gases emitted per unit of electricity consumed. It is usually reported in units of pounds of greenhouse gases per kilowatt-hour (kWh) or megawatt-hour (MWh). The Protocol stipulates that if your electricity provider is a member of the California Climate Action Registry and has "verified an electricity deliveries metric under CCAR's Power/Utility Protocol" this factor can be used to determine $\mathrm{CO}_{2}$ emissions from purchased electricity ${ }^{80}$. The verified utility-specific electricity $\mathrm{CO}_{2}$ emission factor for Pacific Gas $\&$ Electric is $489.16 \mathrm{lbs}$ of $\mathrm{CO}_{2}$ per MWh of electricity consumed in 2005.

Under the Protocol, local governments in California are to use the $\mathrm{CH}_{4}$ and $\mathrm{N}_{2} \mathrm{O}$ default emission factors (California Grid Average Electricity Emission Factors) used by the California Air Resources Board in the Inventory of California Greenhouse Gas Emissions and Sinks: 1990 to $2004^{81}$. The emission factor for $\mathrm{CH}_{4}$ is 0.029 pounds of $\mathrm{CH}_{4}$ per MWh of electricity consumed. The emission factor for $\mathrm{N}_{2} \mathrm{O}$ is 0.011 pounds of $\mathrm{N}_{2} \mathrm{O}$ per MWh of electricity consumed. The most recent year for which electricity emission factors for $\mathrm{N}_{2} \mathrm{O}$ and $\mathrm{CH}_{4}$ are available is 2004; these emission factors are to be used for inventories for more recent years as a baseline year.

\section{Step 3: Determine total annual emissions and convert to $\mathrm{MTCO}_{2} \mathrm{e}$ emissions.}

To determine annual emissions, multiply annual electricity use (in MWh) from Step 1 by the emission factors for $\mathrm{CO}_{2}, \mathrm{CH}_{4}$, and $\mathrm{N}_{2} \mathrm{O}$ (in lbs/MWh) from Step 2. The resulting product is then converted into metric tons by dividing by the total by 2,204.62 lbs/metric ton (See Equation C.1).

\footnotetext{
${ }^{80}$ California Air Resources Board, AB 32 Scoping Plan, December 2008, page 38.

${ }^{81}$ California Energy Commission, Inventory of California Greenhouse Gas Emissions and Sinks: 1990-2004, Sacramento, California, CEC-600-2006-013-SF, December 2006.
} 


\begin{tabular}{|c|}
\hline $\begin{array}{l}\text { Equation C.1: Calculate indirect emissions } \\
\text { from electricity use }\end{array}$ \\
\hline $\begin{array}{l}\mathrm{CO}_{2} \text { Emissions }(\text { metric tons) }= \\
\begin{array}{ccl}\text { Electricity Use } & \text { Emission Factor / } & 2,204.62 \\
(\mathrm{MWh}) & \left(\mathrm{lbs} \mathrm{CO}_{2} / \mathrm{MWh}\right) & (\mathrm{lbs} / \text { metric ton })\end{array}\end{array}$ \\
\hline $\begin{array}{lll}\mathrm{CH}_{4} \text { Emissions } & \text { (metric tons) }= \\
\begin{array}{ccl}\text { Electricity Use } & \text { Emission Factor } / & 2,204.62 \\
(\mathrm{MWh}) & \left(\mathrm{lbs} \mathrm{CH}_{4} / \mathrm{MWh}\right) & \text { (lbs/metric ton })\end{array}\end{array}$ \\
\hline 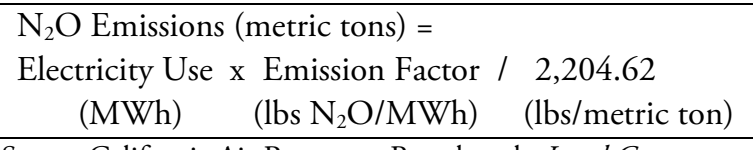 \\
\hline
\end{tabular}

Source: California Air Resources Board et al., Local Government Operations Protocol

To convert $\mathrm{CH}_{4}$ and $\mathrm{N}_{2} \mathrm{O}$ into units of carbon dioxide equivalent, multiply total emissions of each gas (in metric tons) by its IPCC global warming potential (GWP) factor provided in Equation C.2. Emissions from the three greenhouse gases are then summed to obtain total emissions.

\begin{tabular}{|c|}
\hline $\begin{array}{l}\text { Equation C.2: Convert to } \mathrm{CO}_{2} \text {-equivalent } \\
\text { emissions and determine total emissions }\end{array}$ \\
\hline 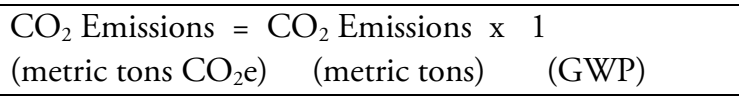 \\
\hline $\begin{array}{l}\begin{array}{l}\mathrm{CH}_{4} \text { Emissions }=\mathrm{CH}_{4} \text { Emissions } \mathrm{x} \\
\left.\text { (metric tons } \mathrm{CO}_{2} \mathrm{e}\right) \quad \text { (metric tons) }\end{array} \text { (GWP) } \\
\end{array}$ \\
\hline $\begin{array}{l}\mathrm{N}_{2} \mathrm{O} \text { Emissions }=\mathrm{N}_{2} \mathrm{O} \text { Emissions } \times 310 \\
\left.\text { (metric tons } \mathrm{CO}_{2} \mathrm{e}\right) \quad \text { (metric tons) }\end{array}$ \\
\hline $\begin{array}{l}\begin{array}{l}\text { Total Emissions }=\mathrm{CO}_{2}+\mathrm{CH}_{4}+\mathrm{N}_{2} \mathrm{O} \\
\left.\text { (metric tons } \mathrm{CO}_{2} \mathrm{e}\right)\end{array} \quad \text { (metric tons } \mathrm{CO}_{2} \mathrm{e} \text { ) }\end{array}$ \\
\hline
\end{tabular}

Source: California Air Resources Board et al., Local Government Operations Protocol

\section{C.2 Quantify emissions from natural gas}

Several of the City's facilities consume natural gas, a form of stationary combustion, which is a Scope 1 emission. The combustion of natural gas, a fossil fuel, yields $\mathrm{CO}_{2}$, and to a smaller extent, $\mathrm{N}_{2} \mathrm{O}$ and $\mathrm{CH}_{4}$. Under the Local Government Operations Protocol, this inventory will report Scope 1 emissions from stationary combustion in the following sectors:

- Buildings and facilities using natural gas; and the 
- Wastewater facilities (water reclamation facility only).

Reporting these sectors separately facilitates a more useful comparison of municipal emissions over time.

Under the Protocol, the recommended approach to calculate emissions from stationary combustion of natural gas involves the following steps:

1. Determine annual consumption of natural gas combusted at city facilities;

2. Determine the appropriate $\mathrm{CO}_{2}$ emission factors for natural gas;

3. Determine the appropriate $\mathrm{CH}_{4}$ and $\mathrm{N}_{2} \mathrm{O}$ emission factors for natural gas;

4. Calculate $\mathrm{CO}_{2}$ emissions from the combustion of natural gas;

5. Calculate $\mathrm{CH}_{4}$ and $\mathrm{N}_{2} \mathrm{O}$ emissions from the combustion of natural gas; and

6. Convert $\mathrm{CH}_{4}$ and $\mathrm{N}_{2} \mathrm{O}$ emissions to $\mathrm{CO}_{2}$-equivalent emissions and determine total emissions.

\section{Step 1: Determine annual consumption of natural gas at city facilities.}

Monthly natural gas bills determine the amount of natural gas used by each facility. Monthly bills were aggregated to determine the annual electricity use for each facility. Fuel use is measured in therms.

\section{Step 2: Select the appropriate $\mathrm{CO}_{2}$ emission factor for natural gas.}

The Protocol provides default emission factors for a wide variety of fuels in Appendix G of that document (Table G.1). Emission factors are provided in $\mathrm{CO}_{2}$ emissions per unit energy and $\mathrm{CO}_{2}$ emissions per unit mass or volume. The weighted U.S. average emission factor for natural gas is 
$53.06 \mathrm{~kg} \mathrm{CO} 2$ emissions per MMBtu (one-million Btu) and is used in calculations for natural gas usage in this inventory.

\section{Step 3: Determine the appropriate $\mathrm{CH}_{4}$ and $\mathrm{N}_{2} \mathrm{O}$ emission factors for natural gas.}

The Protocol provides default emission factors in Appendix G of that document (Table G.3). Emission factors are provided in units of $\mathrm{CH}_{4}$ or $\mathrm{N}_{2} \mathrm{O}$ emissions per unit energy. The Protocol suggests that local governments use the "commercial/institutional" sector emission factors. The emission factor for $\mathrm{CH}_{4}$ is $5.9 \mathrm{~g}$ per MMBtu $(0.0059 \mathrm{~kg} / \mathrm{MMBtu})$. The emission factor for $\mathrm{N}_{2} \mathrm{O}$ is $0.1 \mathrm{~g}$ per MMBtu $(0.0001 \mathrm{~kg} / \mathrm{MMBtu})$. These are the "California Coefficients for Natural Gas".

\section{Step 4: Calculate $\mathrm{CO}_{2}$ emissions from the combustion of natural gas.}

To determine $\mathrm{CO}_{2}$ emissions from stationary combustion, natural gas usage figures must first be converted from therms to MMBtu (1 therm equals 100,000 Btu or 0.1 MMBtu). Natural gas usage (in MMBtu) is then multiplied by the $\mathrm{CO}_{2}$ emission factor, and then divided by 1,000 to convert from kilograms to metric tons (see Equation C.3).

\begin{tabular}{l}
\begin{tabular}{|l|}
\hline Equation C.3: Calculate $\mathrm{CO}_{2}$ emissions from \\
stationary combustion (fuel use in MMBtu)
\end{tabular} \\
\hline Fuel A $\mathrm{CO}_{2}$ Emissions (metric tons) $=$ \\
Fuel Consumed x Emission Factor / 1,000 \\
(MMBtu) (lbs CO$/$ MMBtu) (kg/metric ton) \\
Source: California Air Resources Board et al., Local Government Operations Protocol
\end{tabular}

Step 5: Calculate $\mathrm{CH}_{4}$ and $\mathrm{N}_{2} \mathrm{O}$ emissions and convert to metric tons.

To determine $\mathrm{CH}_{4}$ emissions from stationary combustion, multiply fuel use from Step 1 by the $\mathrm{CH}_{4}$ emission factor from Step 3, and then convert kilograms to metric tons (see Equation C.4).

The same procedure is followed to calculate total $\mathrm{N}_{2} \mathrm{O}$ emissions at a particular city facility, using Equation C.5. 


\title{
Equation C.4: Calculate $\mathrm{CH}_{4}$ emissions from stationary combustion \\ $\mathrm{CH}_{4}$ Emissions (metric tons) $=$ \\ Fuel Use x Emission Factor / 1,000 \\ (MMBtu) $\quad\left(\mathrm{kg} \mathrm{CH}_{4} / \mathrm{MMBtu}\right) \quad$ (kg/metric ton) \\ Source: California Air Resources Board et al., Local Government Operations Protocol
}

\author{
Equation C.5: Calculate $\mathrm{N}_{2} \mathrm{O}$ emissions from \\ stationary combustion \\ Fuel $\mathrm{A} \mathrm{N}_{2} \mathrm{O}$ Emissions (metric tons) $=$ \\ Fuel Use x Emission Factor / 1,000 \\ (MMBtu) ( $\left.\mathrm{kg} \mathrm{N}_{2} \mathrm{O} / \mathrm{MMBtu}\right) \quad(\mathrm{kg} /$ metric ton) \\ Source: California Air Resources Board et al., Local Government Operations Protocol
}

Step 6: Convert $\mathrm{CH}_{4}$ and $\mathrm{N}_{2} \mathrm{O}$ emissions to units of $\mathrm{CO}_{2}$ equivalent and determine total

emissions from stationary combustion.

The global warming potential (GWP) factors established by the Intergovernmental Panel on

Climate Change's Second Assessment Report are used to convert $\mathrm{CH}_{4}$ and $\mathrm{N}_{2} \mathrm{O}$ emissions to units of

$\mathrm{CO}_{2}$-equivalent emissions. The sum of emissions from the three greenhouse gases will determine the total emissions from stationary combustion at city facilities (see Equation C.6).

\begin{tabular}{|l|}
\hline $\begin{array}{l}\text { Equation C.6: Convert to } \mathrm{CO}_{2} \text {-equivalent } \\
\text { emissions and determine total emissions }\end{array}$ \\
\hline $\begin{array}{l}\mathrm{CO}_{2} \text { Emissions }=\mathrm{CO}_{2} \text { Emissions } \mathrm{x} \quad 1 \\
\left.\text { (metric tons } \mathrm{CO}_{2} \mathrm{e}\right) \quad \text { (metric tons) (GWP) }\end{array}$ \\
\hline $\begin{array}{l}\mathrm{CH}_{4} \text { Emissions }=\mathrm{CH}_{4} \text { Emissions } \mathrm{x} \quad 21 \\
\left.\text { (metric tons } \mathrm{CO}_{2} \mathrm{e}\right) \text { (metric tons) (GWP) }\end{array}$ \\
\hline $\begin{array}{l}\mathrm{N}_{2} \mathrm{O} \text { Emissions }=\mathrm{N}_{2} \mathrm{O} \text { Emissions } \times 310 \\
\left.\text { (metric tons } \mathrm{CO}_{2} \mathrm{e}\right) \quad \text { (metric tons) (GWP) }\end{array}$ \\
\hline $\begin{array}{l}\text { Total Emissions }=\mathrm{CO}_{2}+\mathrm{CH}_{4}+\mathrm{N}_{2} \mathrm{O} \\
\left.\left.\text { (metric tons } \mathrm{CO}_{2} \mathrm{e}\right) \quad \text { (metric tons } \mathrm{CO}_{2} \mathrm{e}\right)\end{array}$ \\
Source: California Air Resources Board et al., Local Government Operations Protocol
\end{tabular}




\section{C.3 Quantify emissions from mobile combustion}

Under the City's operation, mobile combustion sources include both on-road and off-road vehicle such as automobiles, trucks, buses, and construction equipment. The combustion of fossil fuels in mobile sources emits $\mathrm{CO}_{2}, \mathrm{CH}_{4}$ and $\mathrm{N}_{2} \mathrm{O}$.

Emissions from mobile combustion can be estimated based on vehicle fuel use and VMT data. Carbon dioxide emissions, which account for the majority of emissions from mobile sources, are directly related to the quantity of fuel combusted and can be calculated using fuel consumption data. Methane and nitrous oxide emissions depend more on the emission control technology employed in the vehicle and distance traveled. Calculating $\mathrm{CH}_{4}$ and $\mathrm{N}_{2} \mathrm{O}$ emissions requires data on vehicle characteristics (which takes into account emission control technologies) and vehicle-miles of travel.

Calculating Scope $1 \mathrm{CO}_{2}$ emissions from mobile combustion involves three steps:

- Identify total annual fuel consumption by fuel type;

- Determine the appropriate emission factor; and

- Calculate total $\mathrm{CO}_{2}$ emissions.

\section{Step 1: Identify total annual fuel consumption by fuel type.}

Methods for determining total annual fuel consumption include direct measurements of fuel use (official logs of vehicle fuel gauges or storage tanks); collected fuel receipts; and purchase records for bulk storage fuel purchases (in cases where fuel is stored at a facility). Total annual fuel purchases should include both fuel purchased for the bulk fueling facility and fuel purchased for vehicles at other fueling locations. In the case of the City of San Luis Obispo, purchase records for bulk storage fuel purchases were used to determine annual fuel consumption. In the baseline year of 2005, only 
gasoline and diesel were used to fuel the City's vehicle fleet. Equation C.7 below may be used to determine the total fuel that was actually consumed.

\begin{tabular}{l}
\hline $\begin{array}{l}\text { Equation C.7: Account for changes in fuel stocks from } \\
\text { bulk purchases }\end{array}$ \\
\hline $\begin{array}{l}\text { Total Annual Consumption = Total Annual Fuel Purchases + Amount } \\
\text { Stored at Beginning of Year - Amount Stored at End of Year }\end{array}$ \\
Source: California Air Resources Board et al., Local Government Operations Protocol
\end{tabular}

At the time of the data collection process for this inventory, only total annual fuel purchases were determined; the amount stored at the beginning of the year and at the end of the year was not determined. Additionally, fuel purchased for vehicles at other fueling locations was not determined.

Step 2: Determine the appropriate $\mathrm{CO}_{2}$ emission factor for each fuel.

As it is not yet standard practice for states or regions to develop state- or region-specific emission factors for their fuel blends, the Protocol recommends the use of widely-accepted national averages as the emission factor for use in calculating emissions from mobile combustion. The Protocol provides default emission factors for transport fuels in Appendix G of that document (Table G.9). The $\mathrm{CO}_{2}$ emission factor for Motor Gasoline is $8.81 \mathrm{~kg} \mathrm{CO}_{2}$ per gallon; the $\mathrm{CO}_{2}$ emission factor for Diesel Fuel No. 1 and 2 is $10.15 \mathrm{~kg} \mathrm{CO} 2$ per gallon.

\section{Step 3: Calculate total $\mathrm{CO}_{2}$ emissions and convert to metric tons.}

To determine $\mathrm{CO}_{2}$ emissions from mobile combustion, fuel use from Step 1 is multiplied by the $\mathrm{CO}_{2}$ emission factor from Step 2; the resulting product is converted from kilograms to metric tons (see Equation C.8). This is repeated for both fuel types used by the city's vehicle fleet - gasoline and diesel. 


\begin{tabular}{|c|}
\hline $\begin{array}{l}\text { Equation C.8: Calculate } \mathrm{CO}_{2} \text { emissions from } \\
\text { mobile combustion }\end{array}$ \\
\hline $\begin{array}{l}\text { Fuel } \mathrm{A} \mathrm{CO}_{2} \text { Emissions (metric tons) }= \\
\begin{array}{l}\text { Fuel Consumed } \\
\quad \text { (gallons })\end{array} \quad \begin{array}{l}\text { Emission Factor } / \\
\left(\mathrm{kg} \mathrm{CO}_{2} / \text { gallon }\right)\end{array} \quad(\mathrm{kg} / \text { metric ton })\end{array}$ \\
\hline $\begin{array}{l}\text { Fuel } \mathrm{B} \mathrm{CO}_{2} \text { Emissions (metric tons) }= \\
\begin{array}{ccc}\text { Fuel Consumed } & \text { Emission Factor } / & 1,000 \\
(\text { gallons }) & \left(\mathrm{kg} \mathrm{CO}_{2} / \text { gallon }\right) & (\mathrm{kg} / \text { metric ton })\end{array}\end{array}$ \\
\hline $\begin{array}{l}\text { Total } \mathrm{CO}_{2} \text { Emissions (metric tons) }= \\
\mathrm{CO}_{2} \text { from Fuel } \mathrm{A}+\mathrm{CO}_{2} \text { from Fuel } \mathrm{B} \\
\text { (metric tons) }\end{array}$ \\
\hline
\end{tabular}

Calculating Scope $1 \mathrm{CH}_{4}$ and $\mathrm{N}_{2} \mathrm{O}$ emissions from mobile combustion involves five steps:

1) Identify the vehicle type, fuel type, and model year of each vehicle owned and operated by the City;

2) Identify the annual mileage by vehicle type;

3) Select the appropriate emission factor for each vehicle type;

4) Calculate $\mathrm{CH}_{4}$ and $\mathrm{N}_{2} \mathrm{O}$ emissions for each vehicle type and sum to obtain total $\mathrm{CH}_{4}$ and $\mathrm{N}_{2} \mathrm{O}$ emissions; and

5) Convert $\mathrm{CH}_{4}$ and $\mathrm{N}_{2} \mathrm{O}$ emissions to units of $\mathrm{CO}_{2}$-equivalent emissions and sum to determine total emissions.

Step 1: Identify the vehicle type, fuel type, and technology type or model year of all the vehicles owned and operated by the City.

An inventory of the City's entire vehicle fleet is necessary to complete this step, including identifying the vehicle type (categorized as passenger car, light truck/SUV/pickup, and heavy-duty truck), fuel type (such as gasoline or diesel), and model year. 


\section{Step 2: Identify the annual mileage by vehicle type.}

Methane and nitrous oxide emissions depend more on distance traveled than volume of fuel consumed. Therefore, the recommended approach is to use vehicle-miles of travel data by vehicle type. The City has recently implemented a fleet management system that will allow city staff to track annual vehicle mileage for each vehicle in its fleet. The vehicle mileage for the fleet for the baseline year of 2005 is considered by City staff to be incomplete and inconsistently collected and tracked. Instead, an estimate of vehicle mileage data is generally available by vehicle type, but data is not available in such a way that it would allow accurate calculation of $\mathrm{CH}_{4}$ and $\mathrm{N}_{2} \mathrm{O}$ emissions per the Protocol. Therefore, $\mathrm{CH}_{4}$ and $\mathrm{N}_{2} \mathrm{O}$ emissions from mobile combustion from the City's vehicle fleet will not be explicitly accurate at this time.

However, the methodology outlined in this report will allow city staff to complete this section of the emissions inventory when sufficient data is available for use (such as one years' worth of vehicle fleet data) and $\mathrm{CH}_{4}$ and $\mathrm{N}_{2} \mathrm{O}$ emissions can be accurately calculated.

Step 3: Select the appropriate emission factor for each vehicle type.

Emission factors for vehicles are available in Table G.10 (in Appendix G) of the Protocol, and are in units of grams of $\mathrm{CH}_{4}\left(\right.$ or $\left.\mathrm{N}_{2} \mathrm{O}\right)$ per mile.

Step 4: Calculate $\mathrm{CH}_{4}$ and $\mathrm{N}_{2} \mathrm{O}$ emissions by vehicle type and sum to obtain total $\mathrm{CH}_{4}$ and $\mathrm{N}_{2} \mathrm{O}$ emissions.

Use Equation C.9 to calculate $\mathrm{CH}_{4}$ emissions by vehicle type, convert to metric tons, and obtain total $\mathrm{CH}_{4}$ emissions. This calculation is repeated using Equation C. 10 to obtain total $\mathrm{N}_{2} \mathrm{O}$ emissions. 


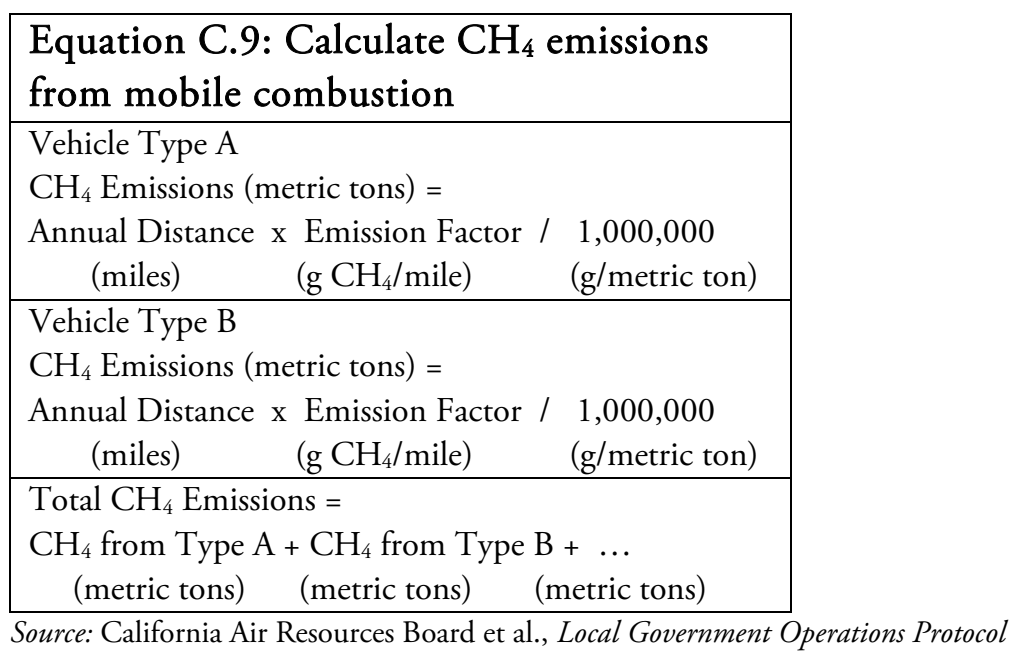

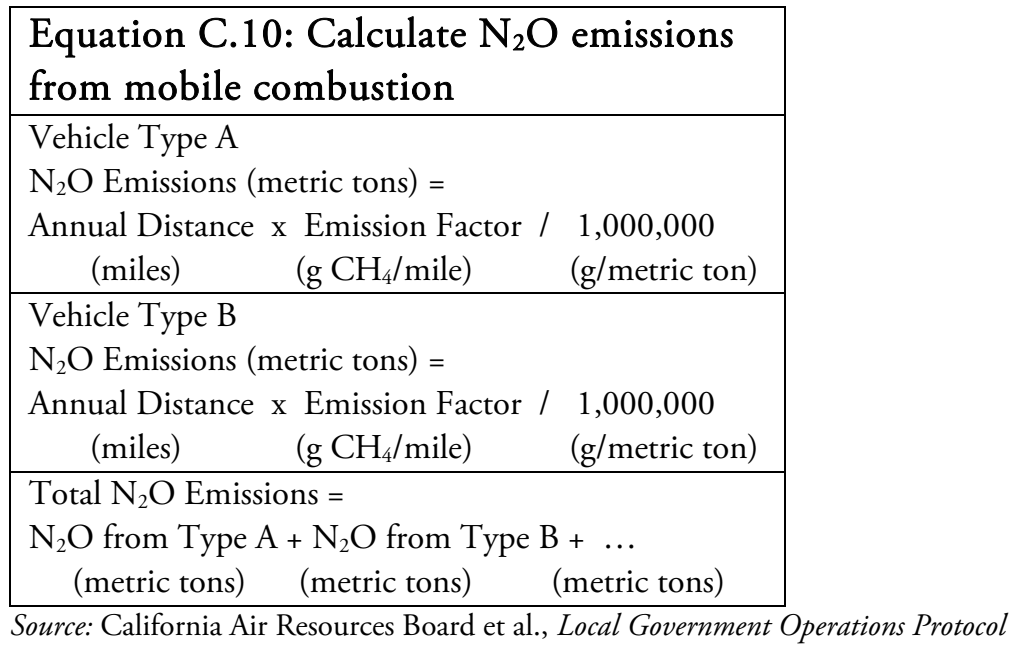

Step 5: Convert $\mathrm{CH}_{4}$ and $\mathrm{N}_{2} \mathrm{O}$ emissions to units of $\mathrm{CO}_{2}$-equivalent emissions and determine total emissions from mobile combustion.

Using the IPCC global warming potential factors found in Equation C.6, $\mathrm{CH}_{4}$ and $\mathrm{N}_{2} \mathrm{O}$ emissions can be converted to units of $\mathrm{CO}_{2}$-equivalent emissions. Emissions of all three gases are then summed to determine the total emissions from mobile combustion. 


\section{Appendix D - U.S. Mayors Climate Protection Agreement}

(As endorsed by the $73^{\text {rd }}$ Annual U.S. Conference of Mayors meeting, Chicago, 2005)

A. We urge the federal government and state governments to enact policies and programs to meet or beat the target of reducing global warming pollution levels to 7 percent below 1990 levels by 2012, including efforts to: reduce the United States' dependence on fossil fuels and accelerate the development of clean, economical energy resources and fuel-efficient technologies such as conservation, methane recovery for energy generation, waste to energy, wind and solar energy, fuel cells, efficient motor vehicles, and biofuels;

B. We urge the U.S. Congress to pass bipartisan greenhouse gas reduction legislation that 1) includes clear timetables and emissions limits and 2) a flexible, market-based system of tradeable allowances among emitting industries; and

C. We will strive to meet or exceed Kyoto Protocol targets for reducing global warming pollution by taking actions in our own operations and communities such as:

a. Inventory global warming emissions in City operations and in the community, set reduction targets and create an action plan.

b. Adopt and enforce land-use policies that reduce sprawl, preserve open space, and create compact, walkable urban communities;

c. Promote transportation options such as bicycle trails, commute trip reduction programs, incentives for car pooling and public transit;

d. Increase the use of clean, alternative energy by, for example, investing in "green tags", advocating for the development of renewable energy resources, recovering landfill methane for energy production, and supporting the use of waste to energy technology;

e. Make energy efficiency a priority through building code improvements, retrofitting city facilities with energy efficient lighting and urging employees to conserve energy and save money;

f. Purchase only Energy Star equipment and appliances for City use;

g. Practice and promote sustainable building practices using the U.S. Green Building Council's LEED program or a similar system;

h. Increase the average fuel efficiency of municipal fleet vehicles; reduce the number of vehicles; launch an employee education program including anti-idling messages; convert diesel vehicles to bio-diesel;

i. Evaluate opportunities to increase pump efficiency in water and wastewater systems; recover wastewater treatment methane for energy production;

j. Increase recycling rates in City operations and in the community;

k. Maintain healthy urban forests; promote tree planting to increase shading and to absorb $\mathrm{CO}_{2}$; and

1. Help educate the public, schools, other jurisdictions, professional associations, business and industry about reducing global warming pollution. 